$\frac{\text { PNL-6750 }}{\text { UC-70 }}$

\title{
Status of FY 1988 Soil-Water Balance Studies on the Hanford Site
}

G. W. Gee

M. L. Rockhold

J. L. Downs

February 1989

Prepared for the U.S. Department of Energy under Contract DE-AC06-76RLO 1830

Pacific Northwest Laboratory Operated for the U.S. Department of Energy by Battelle Memorial Institute 


\title{
DISCLAIMER
}

This report was prepared as an account of work sponsored by an agency of the United States Government. Neither the United States Government nor any agency thereof, nor Battelle Memorial Institute, nor any or their employees, makes any warranty, expressed or implied, or assumes any legal liability or responsibility for the accuracy, completeness, or usefulness of any information, apparatus, product, or process disclosed, or represents that its use would not infringe privately owned rights. Reference herein to any specific commercial product, process, or service by trade name, trademark, manufacturer, or otherwise does not necessarily constitute or imply its endorsement, recommendation, or favoring by the United States Government or any agency thereof, or Battelle Memorial Institute. The views and opinions of authors expressed herein do not necessarily state or reflect those of the United States Government or any agency thereof.

\author{
PACIFIC NORTHWEST LABORATORY \\ operated by \\ BATTELLE MEMORIAL INSTITUTE \\ for the \\ UNITED STATES DEPARTMENT OF ENERGY \\ under Contract DE-AC06-76RLO 1830
}

\author{
Printed in the United States of America \\ Available from \\ National Technical Information Service \\ United States Department of Commerce \\ 5285 Port Royal Road \\ Springfield, Virginia 22161 \\ NTIS Price Codes \\ Microfiche A01
}

Printed Copy

$\begin{array}{cc}\text { Pages } & \begin{array}{c}\text { Price } \\ \text { Codes } \\ \text { 001-025 }\end{array} \\ 026-050 & \text { A02 } \\ 051-075 & \text { A03 } \\ 076-100 & \text { A04 } \\ 101-125 & \text { A05 } \\ 126-150 & \text { A06 } \\ 151-175 & \text { A07 } \\ 176-200 & \text { A08 } \\ 201-225 & \text { A09 } \\ 226-250 & \text { A10 } \\ 251-275 & \text { A11 } \\ 276-300 & \text { A12 } \\ & \text { A13 }\end{array}$



G. W. Gee
M. L. Rockhold
J. L. Downs

February 1989

\author{
Prepared for \\ the U.S. Department of Energy \\ under Contract DE-AC06-76RLO 1830
}

Pacific Northwest Laboratory

Richland, Washington 99352 


\section{EXECUTIVE SUMMARY}

Natural recharge (i.e., the amount of water from meteorological sources, such as rainfall or snowmelt, that infiltrates through the vadose zone to the groundwater table) at the Hanford Site is a variable quantity because it depends on soil, plant, and climatic factors that vary in time and space over the Site. Water balance data have been collected at selected locations at the Hanford Site for the past 10 years in an attempt to measure or estimate natural recharge for known soil, plant, and climatic conditions. The data collected include precipitation, neutron probe measured water content (storage), and drainage measurements from lysimeters. The lysimeter studies provided the first quantitative estimates of natural recharge at the Hanford Site.

Data indicate the some soils at the Hanford Site are very susceptible to drainage. Coarse-textured soils (i.e., soils that contain $90 \%$ or more sandsized or larger particles) that are sparsely vegetated or are covered with shallow-rooted grasses are relatively common to the Hanford Site. These coarse soils, when kept bare or vegetated with sparse grass cover (such as cheatgrass or native bluegrass) have shown evidence that a significant portion of the annual precipitation (particularly that portion that occurs during the winter) can be lost as deep drainage and may eventually recharge the unconfined aquifer. In contrast, deep-rooted plants (i.e., shrubs or weedy species that have roots below $1 \mathrm{~m}$ ) appear to be more effective than shallow-rooted grasses in removing annual precipitation and preventing recharge. At several measurement locations near the 300 North Area of the Hanford Site, where soils are coarse textured and soil surfaces have been kept bare, data from lysimeters indicate that drainage is a significant part of the total water balance. Drainage measurements from twelve bare-surfaced lysimeters in the 300 North Area ranged from $3.1 \mathrm{~cm} / \mathrm{yr}$ to $5.6 \mathrm{~cm} / \mathrm{yr}$, while the total precipitation recorded at the lysimeter location during the past year (July 1987-June 1988) was $12.5 \mathrm{~cm}$. In contrast, no drainage occurred at this same location from a lysimeter that contained deep-rooted vegetation 
(i.e., tumble mustard). The drainage rates from all 300 North Area lysimeters have decreased during the past year, in response to decreased winter precipitation.

The hydraulic properties of soils at the Grass Site (a location near the 300 North Area) were measured using an unsteady drainage-flux method. Two experiments were run. The first experiment indicated that lateral spreading of water occurred in the layered soil at the test site causing an overestimation of hydraulic conductivities. In the second experiment, lateral spreading was prevented by the use of an impermeable border around the plot. The experimental data from the second experiment were used to estimate the hydraulic conductivity of soil layers at the Grass Site. Data from particlesize analyses were used to predict water retention and hydraulic conductivity. Fractal mathematics were used to estimate parameters needed to predict water release (drainage) characteristics. While the laboratory values were predicted reasonably well, the field-measured water release data showed effects of hysteresis, so laboratory-measured drainage curves do not accurately predict field-measured values. The unsaturated hydraulic conductivity data from the field were found in reasonable agreement with laboratory values for the sandy-textured soils, when appropriate fitting parameters were used. However, order-of-magnitude differences in unsaturated hydraulic conductivity are possible, particularly in the water content range typical of field conditions. Calculations of drainage using estimated hydraulic conductivity values, therefore, may be in error by as much as an order of magnitude.

Future work includes monitoring 300 North Area lysimeters for drainage, installation of small lysimeters at the Grass Site, and measuring the water storage changes at the Grass Site and in the 300 North Area and 200 East lysimeter test sites. Neutron probe monitoring has been reactivated at the 200 East lysimeter site. The neutron probe data from the 200 East lysimeter and adjacent sites will be used to compare water-storage changes in bare versus vegetated soils at this location. Gravel-covered lysimeters have been constructed and placed near the Hanford Meteorological Station and will be monitored over the next several years. Weight change and direct collection 
of drainage water from the gravel-covered lysimeters will be used to simulate the water storage and drainage that presently occur at tank-farms on the Hanford Site. 


\section{ACKNOWLEDGMENTS}

This work was funded by the U.S. Department of Energy through the Westinghouse Hanford Waste Management Program Office. We acknowledge the interest and efforts of Kirk Owens of the Waste Management Program Office and Jerry Cammann and Jerry Davis of the Westinghouse Hanford Environmental Technology Group in supporting the publication of this work. We also thank Pacific Northwest Laboratory(a) colleagues who contributed in various ways to this document. Owen Abbey and Randy Kirkham provided instrumentation support and helped with data analysis and interpretation. Chris Kemp and Shannon Goodwin collected neutron probe data, Paula Heller provided laboratory analyses, Mike Kanyid provided tables and graphs from the extensive data base, and Tim Jones and Mike Fayer provided technical review. Scott Tyler of the Desert Research Institute, Reno, Nevada, suggested the use of fractal mathematics to estimate parameters for predicting water retention characteristics. We also acknowledge the support of Tammy Kogan, Debbie Atkin, and the Pacific Northwest Laboratory Text Processing and Technical Communication staff for timely assistance in preparing this document.

(a) Operated for the U.S. Department of Energy by Battelle Memorial Institute. 


\section{CONTENTS}

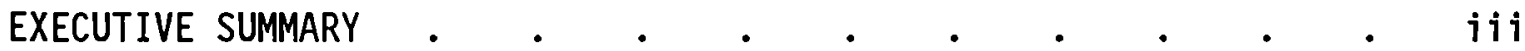

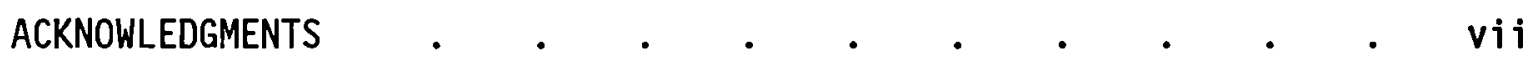

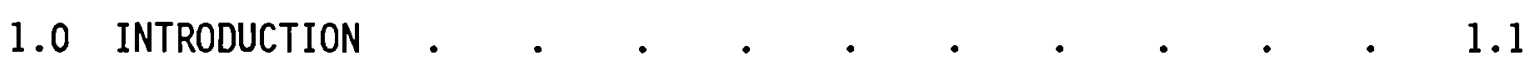

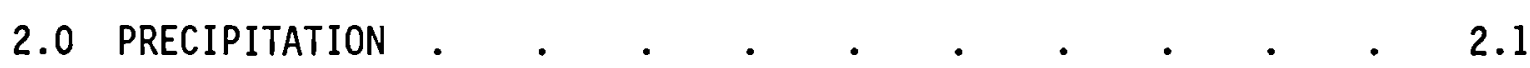

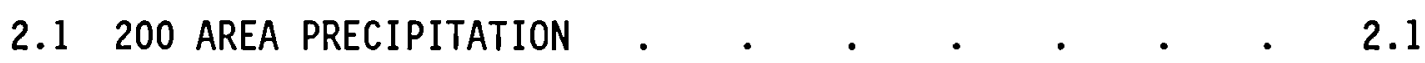

2.2 PRECIPITATION AT THE BWTF AND GRASS SITE $•$. $\quad 2.3$

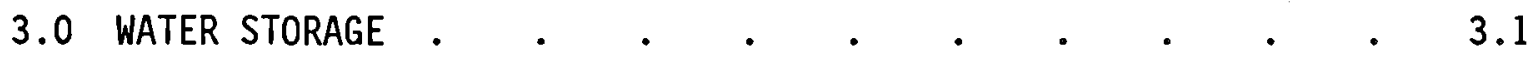

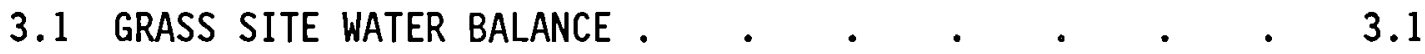

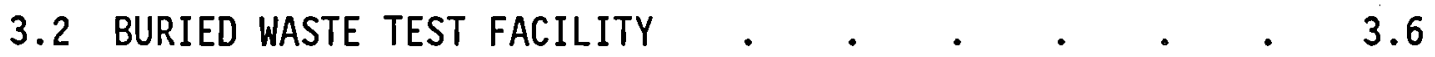

3.3 THE 200 EAST LYSIMETER SITE $\quad$. $\quad$. $\quad . \quad$. $\quad . \quad$. 3.9

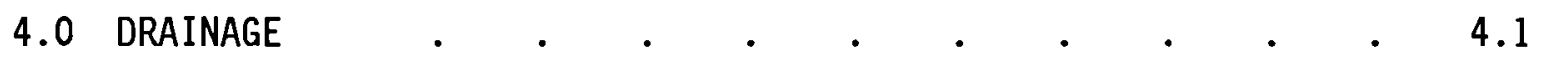

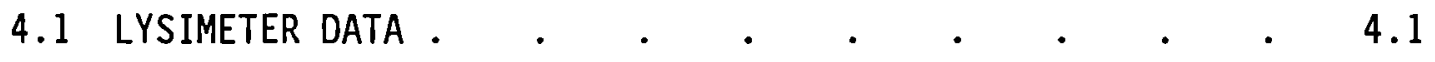

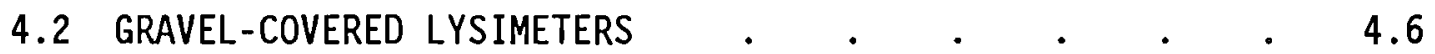

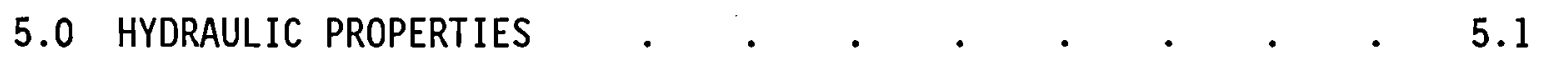

5.1 UNSATURATED HYDRAULIC CONDUCTIVITY FOR

5.2 UNSATURATED HYDRAULIC CONDUCTIVITY FOR

5.3 WATER RETENTION CHARACTERISTIC PREDICTIONS . . . $\quad 5.15$

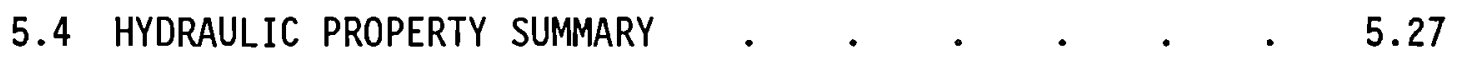

6.0 SITE WATER BALANCE CONSIDERATIONS $\quad . \quad . \quad . \quad . \quad . \quad . \quad 6.1$

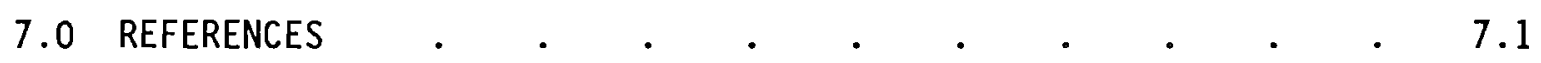

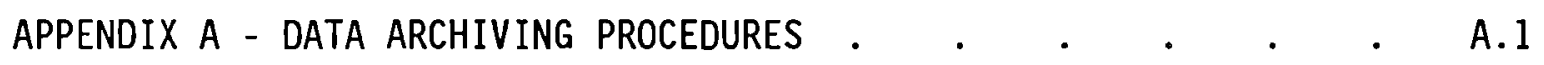

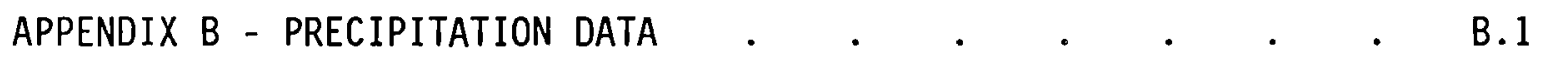

APPENDIX C - WATER STORAGE PROCEDURES AND DATA — . • • • C C.1 


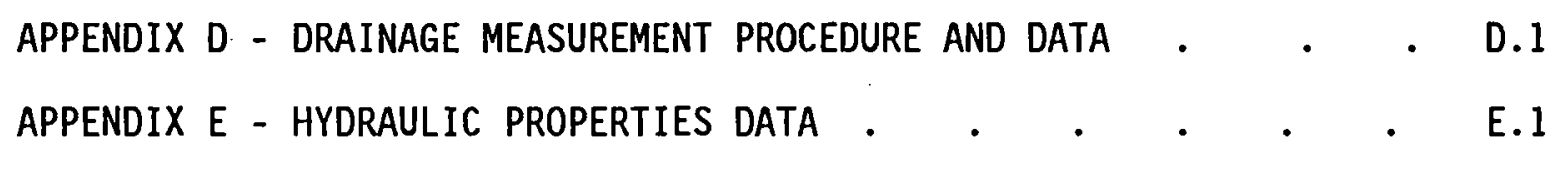




\section{FIGURES}

1.1 Parameters for Annual Water Balance at the

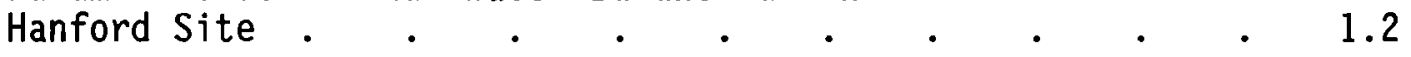

1.2 Hanford Site Map Showing Water Balance Study Areas. . . 1.3

2.1 Precipitation Measured at the Hanford Meteorological

Station and Buried Waste Test Facility from

January 1987 Through August 1988. . . . . . . 2.2

2.2 Comparison of Standard Rain Gauge Data for the Buried

Waste Test Facility and Grass Site, January 1987

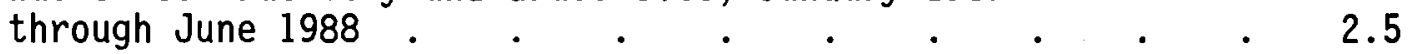

3.1 Schematic View of Neutron Probe Access Tubes at
the Grass Site . . . . . . 3.2

Soil-Water Storage for the Grass Site for
January 1983 to June 1988

3.3 Cumulative Probability Plot of Water Storage for

Individual Neutron Probe Access Tubes on

October 20, 1983, and Apri1 2, 1984 . . . . . 3.5

3.4 Cumulative Probability Plot of Water Storage for

Individual Neutron Probe Access Tubes on January 27,

1988 , and July 7, 1988

3.5 Plan View and Cross Section of the Buried Waste Test

Facility Adjacent to the 300 North Burial Grounds . . 3.7

3.6 Water Storage in the Top 1.2-m Depth of the South Caisson, South Weighing Lysimeter, and North Weighing Lysimeter

at the Buried Waste Test Facility. . . . . . 3.8

3.7 Plan View and Cross Section of 200 East Area

Closed-Bottom Lysimeter . . . . . . . . 3.10

3.8 Excavation Site Near the 200 East Open-Bottom
Lysimeter on January 22, 1988 . . . . . 3.11

Surface of 200 East Closed-Bottom Lysimeter on
January $22,1988 . . .3 .11$

3.10 Access Tube \#4 Located in Sagebrush Cover South of the 200 East Closed-Bottom Lysimeter . . . . . . 3.13

3.11 Access Tube \#5 Located in the Grass Cover South of the 200 East Closed-Bottom Lysimeter . . . . . 3.13 
3.12 Water Content Profile at the 200 East Lysimeter Site for

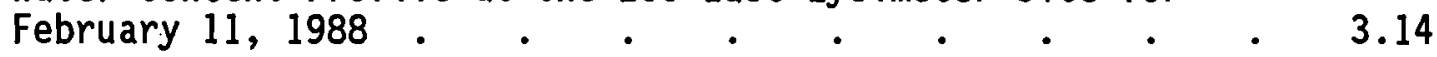

3.13 Water Content Profile at the 200 East Lysimeter Site . . 3.14

3.14 Soil-Water Storage in the Top $5 \mathrm{~m}$ of the Soil Profile as a Function of Time for Closed-Bottom Lysimeter and Adjacent Vegetated Areas at the 200 East Lysimeter Site. • 3.15

4.1 Cumulative Drainage from the South Caisson at the Buried Waste Test Facility . . . . . . . 4.2

4.2 Cumulative Drainage for the North and South Weighing Lysimeters at the Buried Waste Test Facility . . . 4.2

4.3 Schematic of Gravel-Covered Lysimeter Used to Simulate Tank Farm Surface Conditions. . . . . . . 4.7

5.1 Total Head Profiles for First and Second Experiments at the Grass Site . . . . . . 5.3

5.2 Water Content Profiles Measured with a Neutron Probe for First and Second Experiments at the Grass Site . . 5.5

5.3 Comparison of Unsaturated Hydraul ic Conductivity as a Function of Water Content for First and Second Experiments at the Grass Site . . . . . 5.7

5.4 Water Retention Characteristics for the Second Experiment at the Grass Site . . . . . . . 5.8

5.5 Calculated Hydraulic Conductivities for Second Experiment at the Grass Site. . . . . . . 5.10

5.6 Water Retention Characteristics Measured in the Laboratory for Grass Site Soil . . . . . . 5.12

5.7 Field-Measured Water Retention Characteristics from the $30-$ and $45-\mathrm{cm}$ depths in the Second Experiment at the Grass Site . . . . . . . . . 5.13

5.8 Field-Measured Water Retention Characteristics from the $60-$ to $180-\mathrm{cm}$ Depths in the Second Experiment at the Grass Site . . . . . . . . . . 5.13

5.9 Computed Slopes for Particle Number Versus Mean Radius for Soil $F$ of Arya and Paris. 
5.10 Soil-Water Retention Characteristics for the McGee Ranch. a) Represents sample FLTF D10-04; b) represents sample FLTF D11-06

5.11 Soil-Water Retention Characteristics for the McGee Ranch. a) Represents sample FLTF D11-08; b) represents sample

5.12 Predicted Versus Measured Matric Head Values for 16 McGee Ranch Soils for a Range of $-100 \mathrm{~cm}$ to $-5000 \mathrm{~cm}$ of Matric Head

5.13 Particle Number Versus Mean Radius for Grass Site Soils

5.14 Water Retention Curves and Curve-Fitting Parameters for the Grass Site. . . . . . . . . 5.25

5.15 Particle Number Versus Mean Radius for Sandy Soil at the Buried Waste Test Facility . . . . . . 5.26

6.1 Monthly Rainfal1 Distributions Determined from Long-Term Averages at the Hanford Site . . . . . . . 6.3

6.2 Average Monthly Potential Evapotranspiration (PET) at the Hanford Meteorological Station Determined Using the Penman Model for 1978 Through 1987.

6.3 Total Potential Evapotranspiration and Precipitation at the Hanford Meteorological Station for 1978 Through 1987

6.4 Correlation Between Potential Evapotranspiration and Precipitation for 1978 Through 1987 


\section{$\underline{\text { TABLES }}$}

2.1 Record of Precipitation Measurement Methods at the Buried Waste Test Facility for January 1, 1986,

Through July 13, 1988

4.1 Drainage Data for Three Lysimeters at the Buried Waste Test Facility and 10 Lysimeters at the Commercial Waste Test Facility.

4.2 Surface Conditions of South Weighing Lysimeter at the Buried Waste Test Facility . . . . . . 4.4

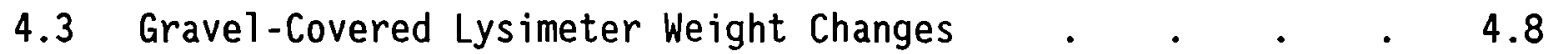

5.1 Grass Site Laboratory Particle-Size and Hydraulic

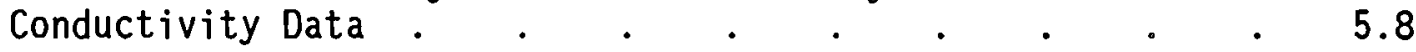

5.2 Laboratory-Measured Water Retention Characteristics for the Grass Site . . . . . . . . . . 5.11

5.3 Results of Soil Particle-Size Analysis for the Field Lysimeter Test Facility. . . . . . . . 5.19

5.4 Fractal Analysis Results of Field Lysimeter Test Facility Soil Particle-Size Distribution Data . . . 5.19

5.5 Curve-Fitting Parameters for the van Genuchten Water Retention and Mualem Predictive Conductivity Models . $\quad 5.28$

6.1 Water Balance Parameters for July 1987 Through June 1988 • 6.2

6.2. Ratio of Actual Evapotranspiration to Predicted Potential Evapotranspiration for July 1987 Through June 1988 


\subsection{INTRODUCTION}

Natural recharge (i.e., input to groundwater from rainfall and snowmelt) occurring below waste storage areas at the Hanford Site is of considerable interest because this recharge provides a possible mechanism for leaching contaminants from waste materials and transporting them to the underlying water reservoir (aquifer). Assessing performance of waste remediation and disposal alternatives requires estimating natural recharge. Natural recharge values are used in calculations that predict the consequence of leaving wastes in place for durations that may be thousands of years (USDOE 1987). Waste management practices and final disposal alternatives may be significantly influenced by knowledge of the rates of natural recharge occurring within the Hanford Site. If natural recharge rates are found to be sufficiently high, particularly near waste storage sites, methods may be required to modify or reduce those rates (e.g., by the use of surface barriers that would limit water infiltration into the wastes) to ensure compliance with applicable regulations.

The purpose of this ongoing study is to quantify the Hanford Site's natural recharge by detailed study of water balance parameters (i.e., precipitation, changes in soil-water storage, evapotranspiration, and drainage), particularly for conditions existing at or near waste burial sites. Previous reports (Gee and Heller 1985; Gee and Jones 1985; Gee 1987) document most of the natural recharge information available before June 1987 . This report provides continuity to those studies by describing subsequent work.

The water balance of a given site can be described as a sum of its individual components as shown in the following equation:

$$
P=\Delta S+E T+D+R
$$

$$
\text { where } \begin{aligned}
P & =\text { precipitation } \\
\Delta S & =\text { water storage change } \\
E T & =\text { evapotranspiration } \\
D & =\text { drainage } \\
R & =\text { runoff (or runon) }
\end{aligned}
$$


In the absence of runoff, water balance relates precipitation directly to the sum of the water storage changes plus evapotranspiration and drainage. At the Hanford Site, the water balance components ( $P, \Delta S$, ET, and $D$ ) can vary markedly with time (Figure 1.1). All water balance components are typically expressed in terms of the amount (volume) of water per unit area so that length units (i.e., $\mathrm{cm}$ of $\mathrm{H}_{2} \mathrm{O}$ ) are used throughout the text.

In theory, calculating water balance is one way to evaluate how well water movement and distribution can be accounted for at a waste site. In practice, however, one or more of the water balance terms cannot be measured and must be calculated indirectly. For this reason, measuring the amount of precipitation stored within the soil cannot by itself be used to predict drainage or recharge. For arid sites, drainage or recharge is a difficult parameter to predict (Gee 1987). Work done at the Hanford Site during the past several years has emphasized the use of drainage Tysimeters to quantify the drainage component of the water balance (Gee 1987; Gee and Jones 1985)

Drainage-type lysimeters, which are soil-filled containers used to collect and measure drainage, can be used along with water storage (i.e.,

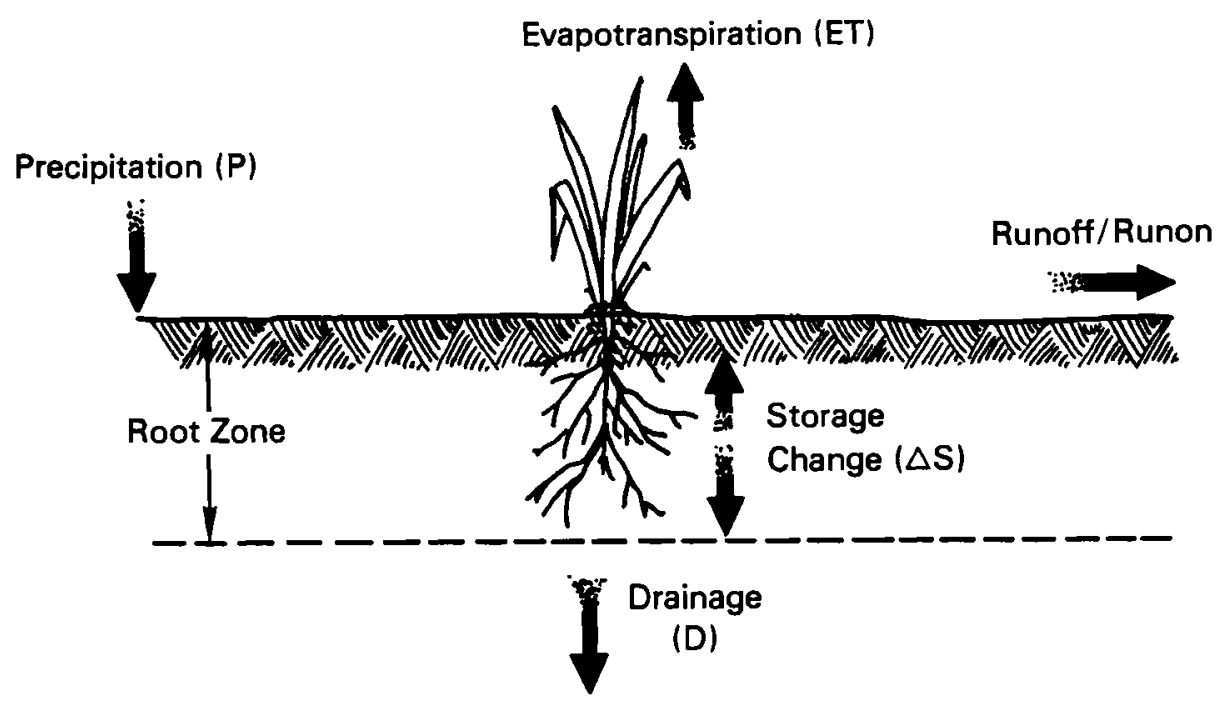

FIGURE 1.1. Parameters for Annual Water Balance at the Hanford Site 
neutron probe) data and precipitation records to obtain water balance parameters at a given site and, therefore, can provide detail about water movement for estimates of contaminant migration for that site. Drainage-type lysimeters where installed in 1978 at the Buried Waste Test Facility (BWTF) in the 300 North Area, which is located northwest of the 300 Area proper and southeast of the Fast Flux Test Facility (FFTF) (see Figure 1.2). Additional drainage lysimeters were installed in 1983 and 1984 at the Commercial Waste Test Facility (CWTF) and Gout Waste Test Facility (GWTF) adjacent to the BWTF. Since then, a series of drainage-type lysimeters, referred to as the 622 Area lysimeters (Figure 1.2), has also been installed adjacent to the Hanford Meteorological Station (HMS) to study barrier designs (Kirkham, Gee, and Downs 1987).

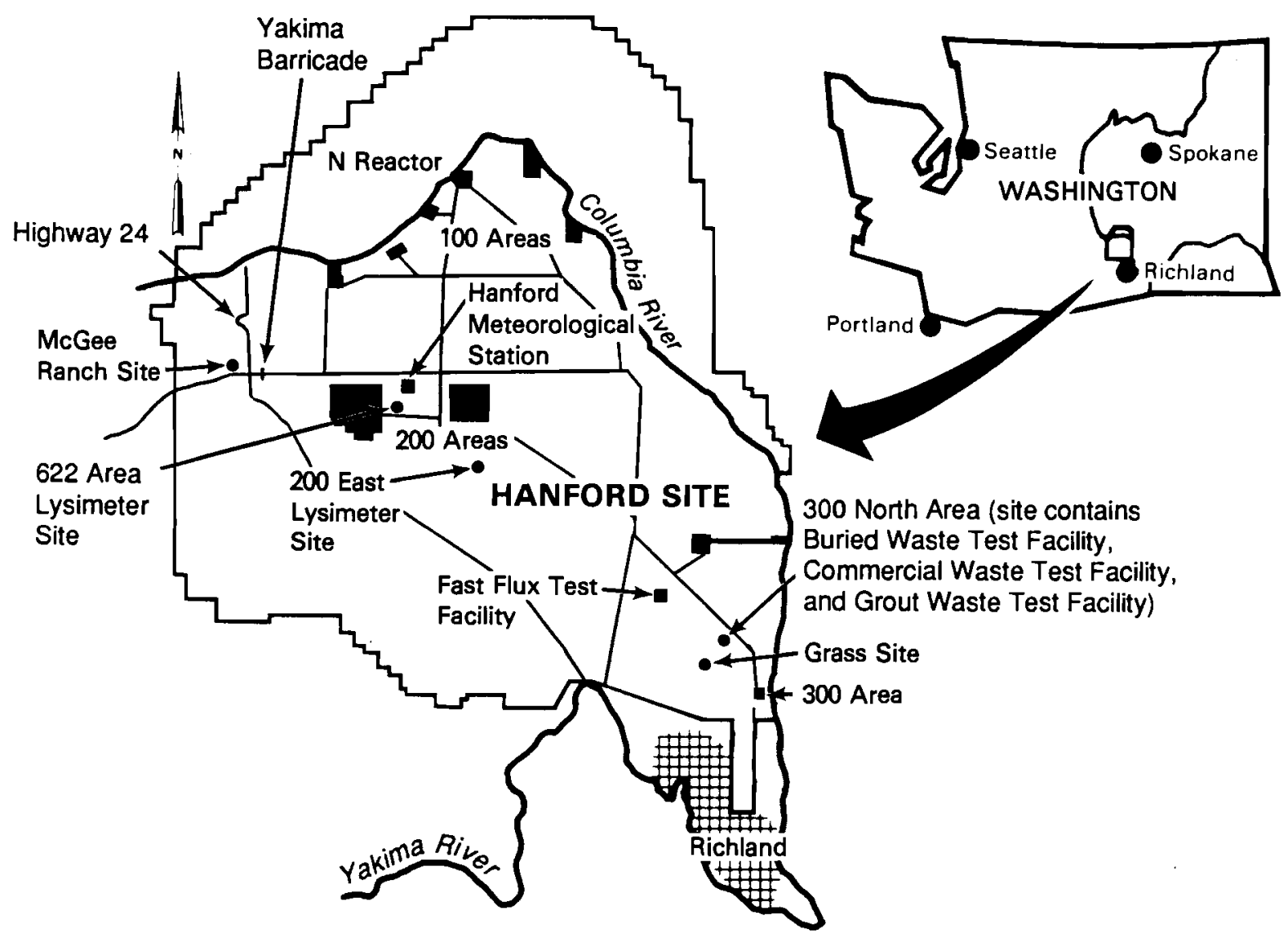

FIGURE 1.2. Hanford Site Map Showing Water Balance Study Areas 
The five areas reported in this water balance study are shown in Figure 1.2. Two of the areas, the BWTF and the Grass Site, are located about $3 \mathrm{~km}$ apart and are northwest of the 300 Area. The terrain at both sites is quite similar, both are in flat depressions surrounded by stabilized sand dunes. The depth to the water table at both sites is about $15 \mathrm{~m}$. The distinguishing feature of the Grass site and its immediate surroundings is the lack of shrub-type vegetation (i.e., the vegetative cover is primarily cheatgrass and bluegrass). Before construction of the BWTF, the immediate area was covered by shrubs and grasses. During construction of the BWTF and lysimeter facilities adjacent to it (Gee and Jones 1985), vegetation was disturbed by excavation and now consists of only sparse grass cover. This test area has been fenced, and three sets of lysimeters are located within the fenced area: the BWTF lysimeters, the CWTF lysimeters, and the GWTF lysimeters. All lysimeters are bare surfaced except one, the south weighing lysimeter of the BWTF. For the purpose of this report, this fenced area and the three sets of lysimeters within are referred to as the 300 North Area. The third area, the 200 East lysimeter site, is located about $3 \mathrm{~km}$ directly south of the 200 East Area. The fourth area is the area surrounding the HMS and is located adjacent to the 200 West Area. This area is designated as the 622 Area and contains a suite of lysimeters. The fifth area, the McGee Ranch site, is located in the Cold Creek valley northwest of the 200 Areas, across Highway 24 from the Yakima Barricade. The 200 East lysimeter site is $17 \mathrm{~km}$ from the McGee Ranch site, with the HMS (622 Area) approximately midway between the two.

The 200 East 1ysimeter site, the HMS, and the McGee Ranch site are all located on the 200 Area Plateau, which is about $80 \mathrm{~m}$ or more above the water table. The vegetation surrounding the 200 Area test locations is diverse, but consists primarily of perennial shrubs (sagebrush and hopsage) and perennial and annual grasses (bluegrass and cheatgrass).

Although the climate is similar at all of these test sites, these locations provide a range of surface soil and plant cover conditions that are typical of much of the Hanford Site. 
This report details the water balance parameters measured at these test sites since 1987. Section 2.0 updates the precipitation measurements made in the 200 and 300 Areas. Section 3.0 updates water storage data and provides a discussion of recent measurements at the 200 East lysimeter site, the oldest lysimeter facility at the Hanford Site. Section 4.0 updates information on drainage measurements at the BWTF and describes the installation of grave1covered lysimeters in the 200 Areas. Section 5.0 describes experiments conducted to obtain field measurements of hydraulic properties. It also describes a proposed method for estimating water retention properties from particle-size analysis using fractal mathematics. Section 6.0 presents a summary of water balance estimates, including annual estimates of potential and actual evapotranspiration for the sites based on measurements reported in previous sections. Limitations of the water balance data set are discussed. Appendices of key data and procedures are also provided. Appendix A identifies data archiving procedures, Appendix $B$ contains precipitation data, Appendix $C$ contains water storage data and the procedure for measuring soil moisture, Appendix $D$ contains drainage data and the procedure for measuring drainage, and Appendix E contains water content, matric potential and hydraulic conductivity data from three field experiments. 


\subsection{PRECIPITATION}

The best documented precipitation records for the Hanford Site are those kept for the Hanford Meteorological Station (HMS) located on the 200 Area Plateau. Precipitation records have also been kept since 1979 for the BWTF and since 1983 for the Grass Site. This section updates precipitation records for these three locations for the 1987-1988 water year (July-June) and discusses real and apparent differences in precipitation among these locations.

\subsection{AREA PRECIPITATION}

Precipitation has been recorded (on at least a daily basis) at the HMS since 1946 (Stone et a1. 1983). Precipitation is currently recorded on an hourly basis using a tipping bucket rain gauge. The data are checked against a standard (8-in.-diameter) collection-type (nonrecording) rain gauge. For the past 10 years, winter precipitation as snow has been measured with a heated tipping bucket rain gauge. Before that, winter precipitation was measured either by collecting snow directly in a collection-type rain gauge and subsequently melting it or by recording snow depth in a cleared area adjacent to the station and obtaining the water equivalent by melting snow and converting measured quantity (weights) into an equivalent water depth (i.e., volume/area).

Precipitation data are stored on magnetic tapes and disks and are avai1-

able from the Atmospheric Sciences Department of Pacific Northwest Laboratory (PNL). These data, along with other climatic data (e.g., temperature, wind speed, humidity, etc.), are currently supplied to the National Oceanic and Atmospheric Administration (NOAA) as the official weather record for the Hanford Site.

Precipitation records for the HMS for January 1, 1986, through August 31, 1988, are shown in Figure 2.1 and Appendix B (Table B.1). The precipitation record for the HMS is assumed to apply to the 200 East Area lysimeter study area as wel1, because they are in relatively similar terrain 


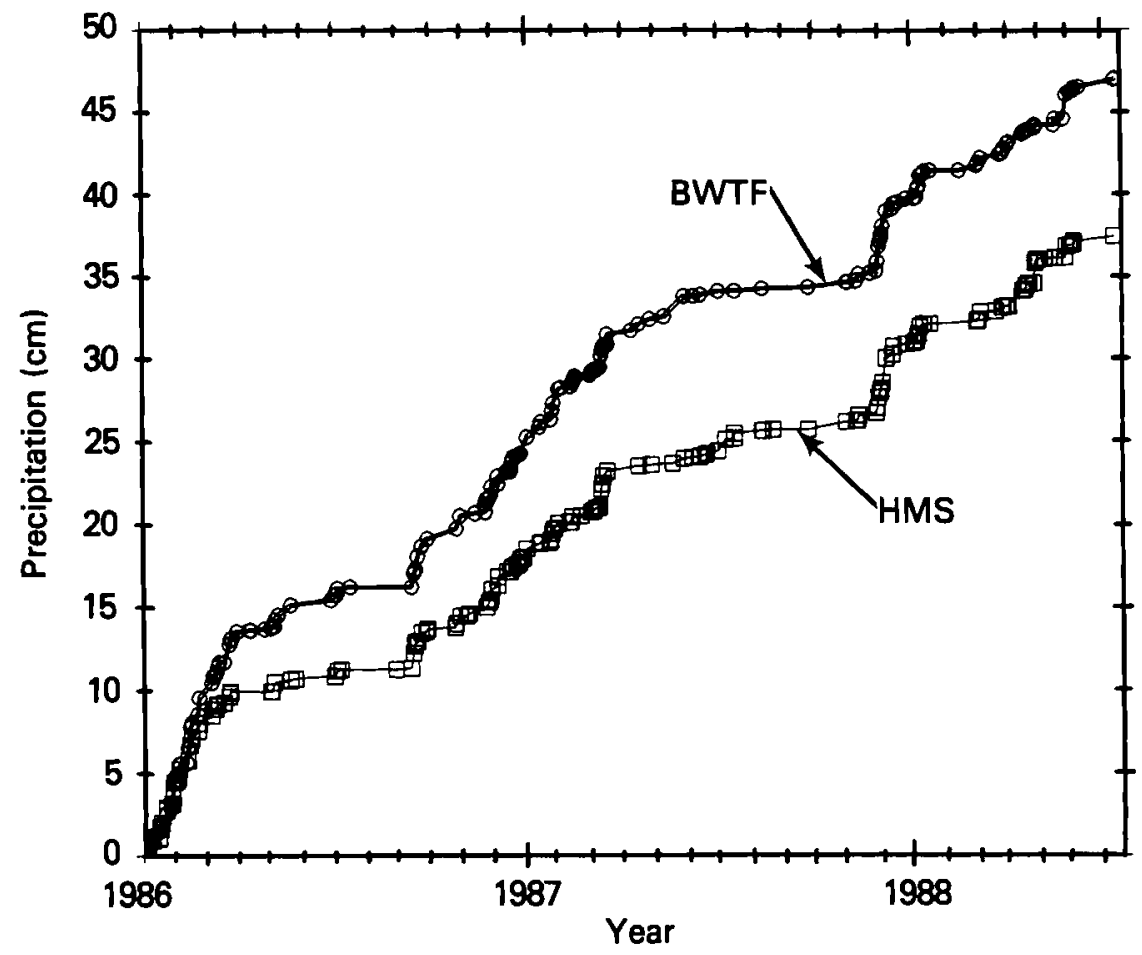

FIGURE 2.1. Precipitation Measured at the Hanford Meteorological Station and Buried Waste Test Facility from January 1987 Through August 1988

and are both located on the 200 Area Plateau. The HMS record indicates that precipitation has been above the long-term average of $16 \mathrm{~cm} / \mathrm{yr}$ (Stone et a1. 1983) for 6 of the past 9 years (1979 through 1987).

However, 2 of the past 3 years have been below the long-term average. In addition, the winter (November through February) precipitation, which normal1y averages $8.3 \mathrm{~cm}$ (Stone et a1. 1983) was lower than the average during each of the past 2 years. Precipitation (rain and snow) totals of $5.7 \mathrm{~cm}$ and $6.4 \mathrm{~cm}$ were measured during the winters of 1986-87 and 1987-88, respectively. In contrast, for the winters of 1982 and 1983, precipitation totals of $13.9 \mathrm{~cm}$ and $13.8 \mathrm{~cm}$, respectively, were recorded. Hence, there has been a twofold variation in wintertime precipitation in the past 6 years.

Potential evapotranspiration is lowest in the winter months. Thus, when precipitation is high in winter, the probability for net water infiltration 
and subsequent recharge is dramatically increased. The effects of variable wintertime precipitation on drainage and recharge at the test sites will be discussed in Section 4.0.

\subsection{PRECIPITATION AT THE BWTF AND GRASS SITE}

Precipitation has been collected at the BWTF in three different ways since January of 1979: tipping bucket, manual rain gauges (either clear-view type or standard nonrecording type), or weighing lysimeters. A tipping bucket rain gauge with a detection limit of $\pm 0.025 \mathrm{~cm}(0.01$ inch) of rain was connected to a data-logging device and has been operational most of the time since 1979. Occasionally, the data logger or the tipping bucket rain gauge has been inoperative. In these instances, data from either the manual rain gauges or the weighing lysimeters has been used to supplement the tipping bucket data. For several relatively short durations since 1979, only HMS data were available for the BWTF and Grass Site. Consequently, these values were used to complete the record.

Table 2.1 lists the time periods when each method was used to collect data at the BWTF from January 1986 through June 1988. The type of collection used in the record is clearly identified when entered into the data base. Cumulative precipitation data for the BWTF, as shown in Figure 2.1 , is a composite of data obtained by al1 three methods of data collection. A comparison of the standard rain gauge data for the BWTF and Grass Site is given in Figure 2.2.

During 1988, in an attempt to improve quality control on precipitation measurements at the BWTF site, a review of the BWTF precipitation data reported by Gee (1987) revealed apparent measurement error from the tipping rain gauge for the winter months (January through March) of 1987. Similar discrepancies were noted in the record for 1986. Although the tipping bucket at the BWTF site was propane heated, apparently the heater did not work adequately and the water equivalent of snow was not properly recorded. In addition, there were times when the data logger was not operational

(Table 2.1). We have subsequently revised the data by checking the winter records against the HMS data to identify expected precipitation dates, and 
TABLE 2.1. Record of Precipitation Measurement Methods at the Buried Waste Test Facility for January 1, 1986, Through July 13, 1988

\begin{tabular}{|c|c|c|}
\hline \multicolumn{2}{|c|}{ Time Period } & \multirow{2}{*}{ Method (a) } \\
\hline Year & Days & \\
\hline 1986 & $\begin{array}{rll}1 & \text { to } & 4 \\
5 & \text { to } & 41 \\
42 & \text { to } & 51 \\
52 & \text { to } & 255 \\
256 & \text { to } & 365\end{array}$ & $\begin{array}{l}\text { WL } \\
T B \\
W L \\
\text { TB } \\
\text { WL }\end{array}$ \\
\hline 1987 & 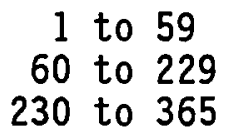 & WL \\
\hline 1988 & $\begin{array}{rll}2 & \text { to } & 4 \\
5 & \text { to } & 13 \\
14 & \text { to } & 100 \\
101 & \text { to } & 119 \\
120 & \text { to } & 195\end{array}$ & $\begin{array}{l}\text { HMS } \\
\text { WL } \\
\text { TB } \\
\text { SC } \\
\text { TB }\end{array}$ \\
\hline
\end{tabular}
(a) Method:
$W L=$ weighing lysimeter
$T B=$ tipping bucket
HMS = Hanford Meteorological Station data
SC = standard collection-type gauge.

then using the weighing lysimeter data where available (primarily during times when drainage was not occurring). During above-freezing conditions, the standard (nonrecording) rain gauge was used to provide the precipitation data when the data logger was not operational.

The detection limit of the tipping rain gauge is $0.025 \mathrm{~cm}(0.01 \mathrm{in.})$ of water, and the resolution of the weighing lysimeter is $0.002 \mathrm{~cm}$ (Kirkham, Gee, and Jones 1984). However, because of known variability in precipitation distribution and difficulties in measuring wintertime snowmelt, the estimated error in the composited precipitation record for the BWTF is likely no less than about 10\%. A comparison of the precipitation record for the BWTF (Gee 1987) and the present data (January 1986 through July 1988) indicates that the precipitation for 1986 and 1987 at the BWTF was underestimated by about $20 \%$. 


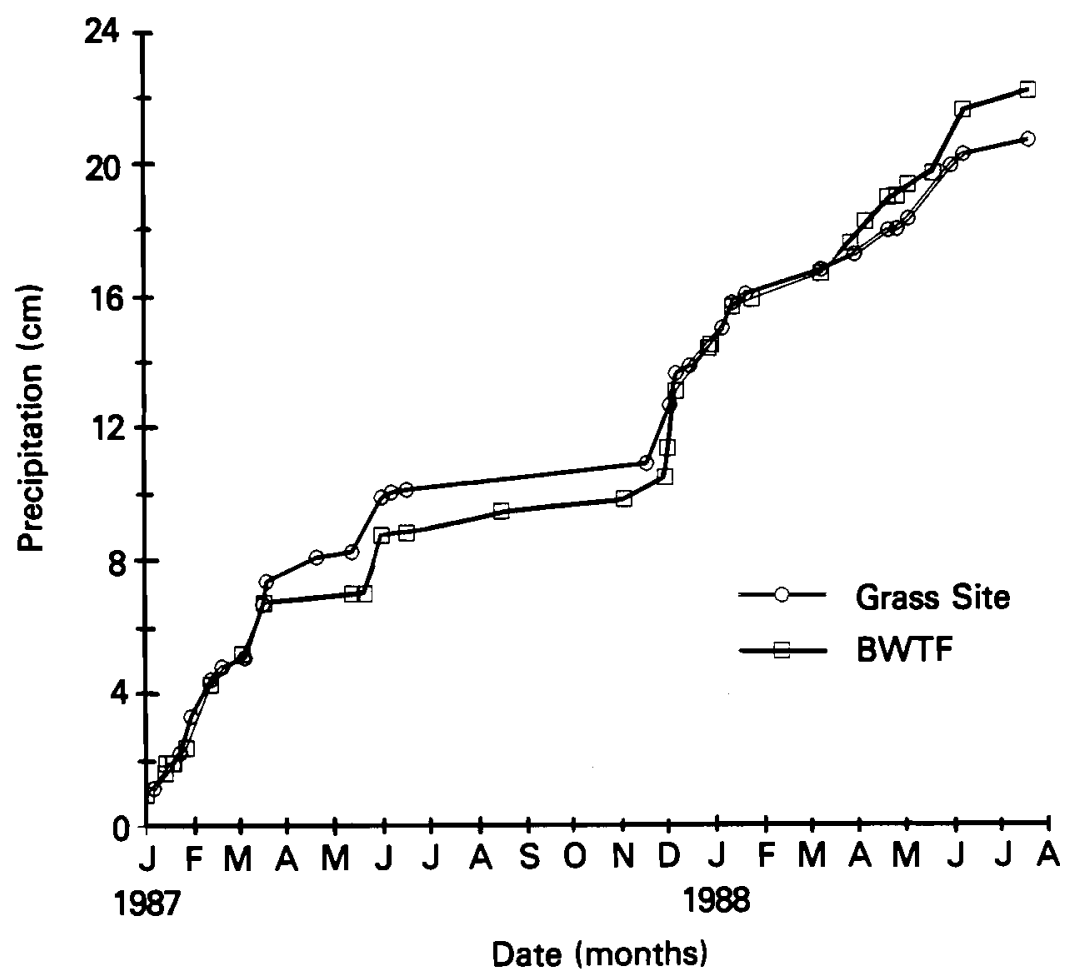

FIGURE 2.2. Comparison of Standard Rain Gauge Data for the Buried Waste Test Facility and Grass Site, January 1987 Through June 1988

In summary, precipitation records are being maintained by the data base from three locations: the HMS, the BWTF, and Grass Site. Since 1986 there appears to be about 20\% more precipitation at the BWTF than at the HMS. The BWTF and Grass Site appear to be receiving similar amounts of precipitation. Variability in collection methods, as well as spatial distribution of precipitation, makes the uncertainty in the data no less than $\pm 10 \%$. 


\subsection{WATER STORAGE}

Neutron probes were used to measure water storage changes at three locations on the Hanford Site. Data were obtained for the Grass Site, the BWTF, and the 200 East 7ysimeter sites. These data are part of the Hanford Site performance assessment data base. Details of the scope of this data base and the procedures used for data storage and retrieval are provided in Appendix A. The calibration procedure and the protocol for using neutron probes to make soil-water storage measurements are shown in Appendix $C$.

\subsection{GRASS SITE WATER BALANCE}

The Grass Site near the 300 Area is being studied because it represents surface conditions (i.e., surface with only sparse grass cover) that may exist at or near waste burial sites after fires or drought conditions. The soil at this site is coarse texture and representative of many soils/surface sediments in the 100 and 200 Area. The vegetative cover of annual and perennial grass (cheatgrass and bluegrass, no shrub growth) on the site has not changed appreciably since testing began in 1983 . Changes in water storage at this site are attributed to variations in climate (precipitation) and to changes in water uptake by plants. To document water storage changes, a network of 25 neutron probe access tubes was installed at the site in December of 1982. Figure 3.1 shows a schematic diagram of the Grass Site and the access tubes. These access tubes have been monitored biweekly to a depth of $3.5 \mathrm{~m}$, since January of 1983 . Figure 3.2 shows the average soil-water storage at the Grass Site. Data indicate little change in water storage occurred below the 1-m depth from January 1987 to June 1988. This small storage change is attributed to below normal precipitation (see Section 2.0). The maximum average water storage to a depth of $3.5 \mathrm{~m}$ during the past year (July 1987 to June 1989) was $20 \mathrm{~cm}$ of water, compared to over $32 \mathrm{~cm}$ of storage measured in early 1983 for the same site. For the past year, virtually all of the storage change at the Grass Site occurred during the winter months and in the top $1 \mathrm{~m}$ of the soil profile. Although essentially no storage change occurred below $1 \mathrm{~m}$ during the past year, water could have nevertheless drained from the profile. 


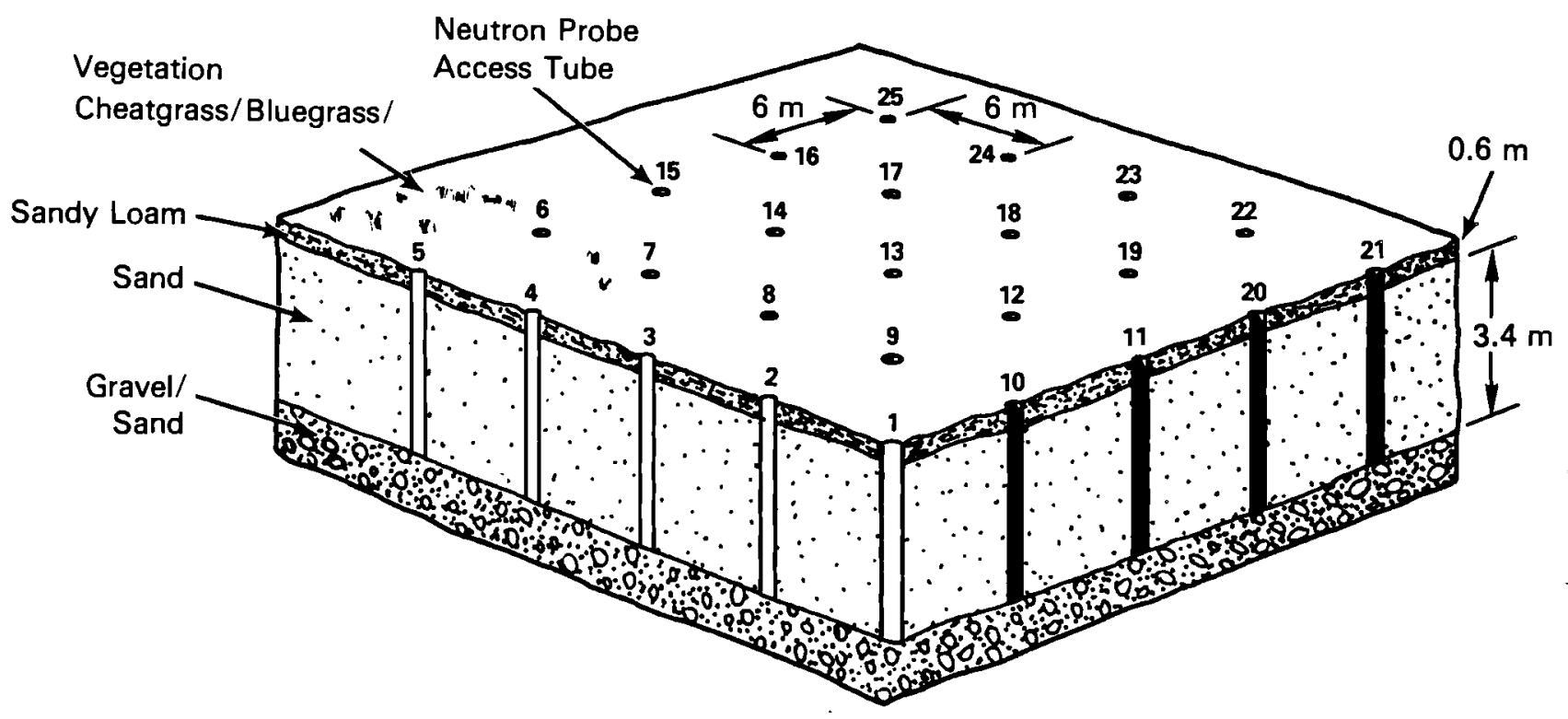

FIGURE 3.1. Schematic View of Neutron Probe Access Tubes at the Grass Site

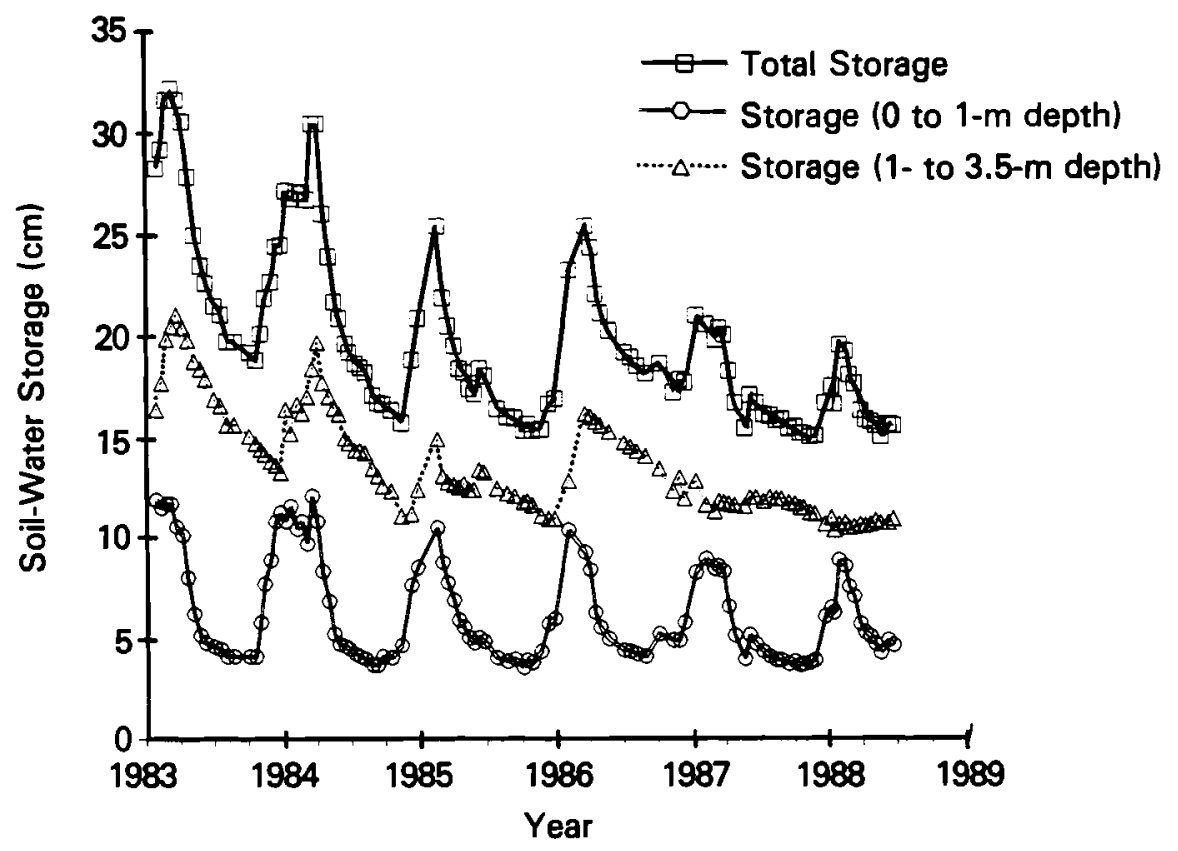

FIGURE 3.2. Soil-Water Storage for the Grass Site for January 1983 to June 1988 
Water drainage rates cannot be directly measured using only the waterstorage data from the neutron probe access tubes. Water storage data provides only one piece of information needed to assess the overall water balance of a site. Water storage can be used to predict drainage only if the evapotranspiration (water loss from soil and plant surfaces) and precipitation are measured independently. However, if water tensions are known and hydraulic property data are available, estimates of drainage rates can be made using neutron probe data (Rockhold, Fayer, and Gee 1988). Section 5.0 details the hydraulic properties measured for the Grass Site; Section 6.0 provides estimates of drainage using hydraulic conductivity data coupled with water storage and water content data.

In a previous report (Gee 1987), water storage values were obtained by summing water content in the interval between two measured depths and then summing over all depth intervals to obtain the total storage. In this report, a trapezoidal method (Green, Ahuja, and Chong 1986) is used for estimating storage. The trapezoidal method for calculating water storage can be expressed as

$$
\int_{0}^{L} \theta(z, t) d z \approx \theta_{1} z_{1}+\sum_{i=2}^{n}\left[\left(\theta_{i-1}+\theta_{i}\right) / 2\right]\left(z_{i}-z_{i-1}\right)
$$

where $L=$ profile depth

$$
z=\text { soil depth }
$$$$
\mathrm{t}=\mathrm{time}
$$

$\mathrm{dz}=$ depth increment

$z_{1}$ and $\theta_{1}=$ the depth and water content for the first measurement position

$\theta_{i}=$ the soil water content measured at the $i^{\text {th }}$ point in the profile starting from the top

$n=$ the number of data points down to depth $L$.

In comparing methods for calculating water storage for selected dates, there were only a few dates for which the use of different methods resulted in a more than $10 \%$ difference in the storage value. Although the storage values 
did not change significantly, the trapezoidal method was judged to be better documented (Green, Ahuja, and Chong 1986) than the other methods. Consequently, the trapezoidal method will be used to calculate soil-water storage from neutron probe information for all test sites.

To assess whether a few selected neutron probe monitoring points could be used to estimate water storage at the Grass Site, analyses were also made of the variation in water storage data from individual access tubes for the site. The temporal stability of the storage values were tested using a method proposed by Vachaud et a1. (1985). Vachaud et al. measured soil water to a depth of $1 \mathrm{~m}$ in 17 access tubes using neutron probes at a field site in France. His test data were stable over a 2.5-year period. In other words, the wettest soil profiles were consistently wetter and the driest soil profiles were consistently drier during the entire 2.5-year period (as the field responded to seasonal changes in water content). Vachaud et a1. (1985) used a cumulative probability plot to show the time stability of the data. The water storage determined from individual access tubes was ranked according to storage values (low to high); this ranking appeared to persist throughout the year. The persistence of the ranking was interpreted to indicate that it may be possible to reduce 1 arge measurement networks (i.e., with many access tubes) to a few representative locations.

Vachand's method was tested using the Grass Site data with relatively poor results. Figures 3.3 and 3.4 are cumulative probability plots of the water storage values for two time periods (October 1983 to April 1984 and January 1988 to April 1988). The curves reflect the probability that storage values will be less than the values shown. The curves provide a convenient way to show the distribution of individual storage values. For both time periods, the ranking of water storage values did not remain consistent, suggesting that values associated with water storage for specific access tubes varied sufficiently to preclude selecting only a few tubes to reflect the storage changes of the overall site. An exception was tube 25 . Tube 25 is the access tube where two unsteady drainage-flux experiments were conducted (see Section 5.0). In these two experiments, supplemental water was applied at the soil surface, and the surface was temporarily covered with plastic to 


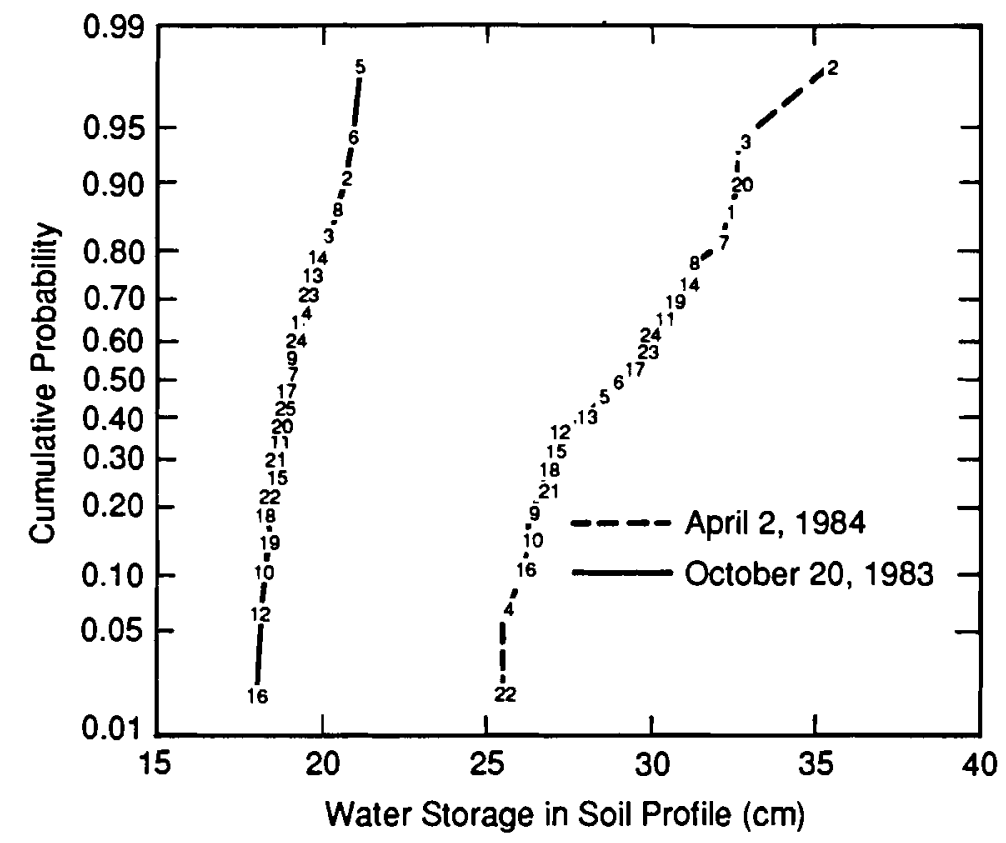

FIGURE 3.3. Cumulative Probability Plot of Water Storage for Individual Neutron Probe Access Tubes on October 20, 1983, and April 2, 1984

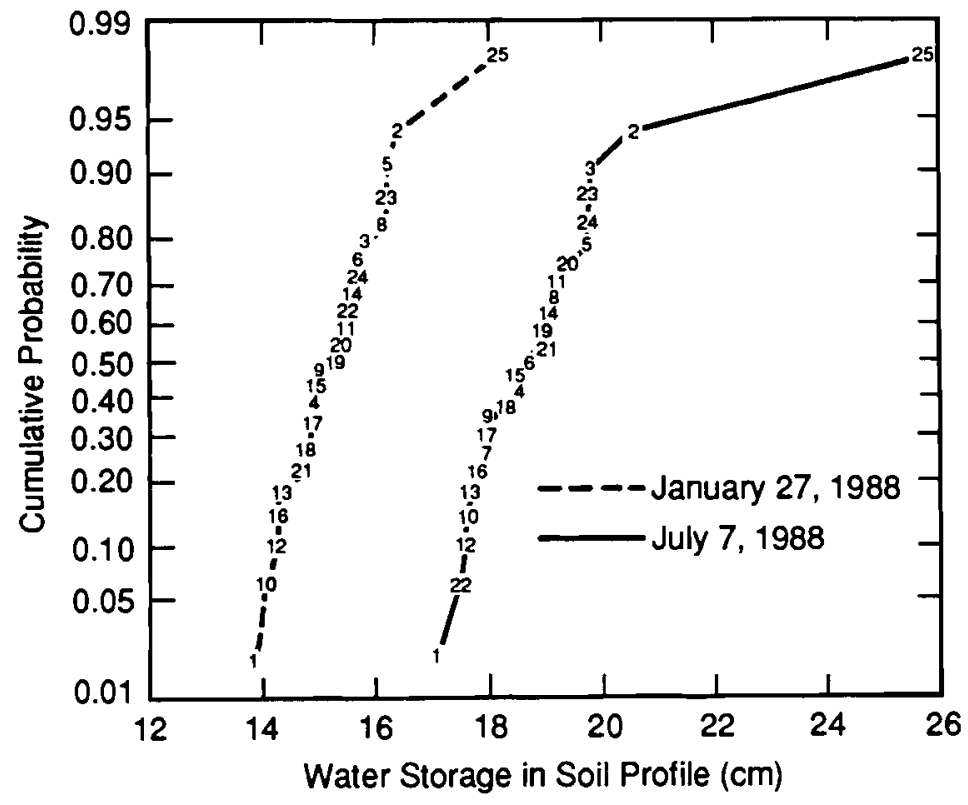

FIGURE 3.4. Cumulative Probability Plot of Water Storage for Individual Neutron Probe Access Tubes on January 27, 1988, and Ju7y 7, 1988 
prevent evaporation in July 1987 and September 1987. The deliberate wetting and covering of the test plot immediately surrounding the access tube explains why the water content was higher for this tube than for any other tube of the Grass Site. In November 1987, the plot surrounding tube 25 was uncovered to permit evaporation. During the past 10 months (from November 1987 to present), grass (primarily cheatgrass) has begun growing on the plot. The storage changes at tube 25 between January and July 1988, shown in Figure 3.4 , reflect the above conditions.

\subsection{BURIED WASTE TEST FACILITY}

The objective of monitoring water storage at the BWTF is to compare soil-water storage changes for bare and vegetated surfaces under conditions of known drainage documented by lysimeters. The lysimeters at the BWTF are filled with coarse sands typical of sediments underlying the 200 Areas and other waste disposal areas of the Hanford Site.

The water balance of the vegetated lysimeter reflects the water storage and drainage at waste sites covered with vegetation. The water balance of the bare-surface lysimeters reflects conditions of maximized recharge. Such bare-surface conditions may exist at waste burial sites denuded by fire or herbicides. Differences in water balance (i.e., storage and drainage) between the vegetated and nonvegetated (bare) surfaces are attributed to differences in evapotranspiration. The BWTF has a more continuous record of soil-water storage than any other location on the Hanford Site.

Figure 3.5 shows $p l$ an and cross-section views of the BWTF facility. The 7.6-m-deep south caisson, the 1.5-m-deep south and north weighing lysimeters are being monitored for water storage on a routine (biweekly) basis. The south caisson and north weighing lysimeter are kept bare. The south weighing lysimeter has been vegetated since March 1983.

Figure 3.6 compares the soil water stored in the top $1.2 \mathrm{~m}$ of each of these lysimeters. An annual water storage cycle is clearly seen. Water storage values for a11 measurement dates, from January 1984 through June 1988, are documented in Appendix C (Tables C.1, C.2, and C.3). During FY 1988 , water storage values for late winter were lower in all lysimeters 
Plan View
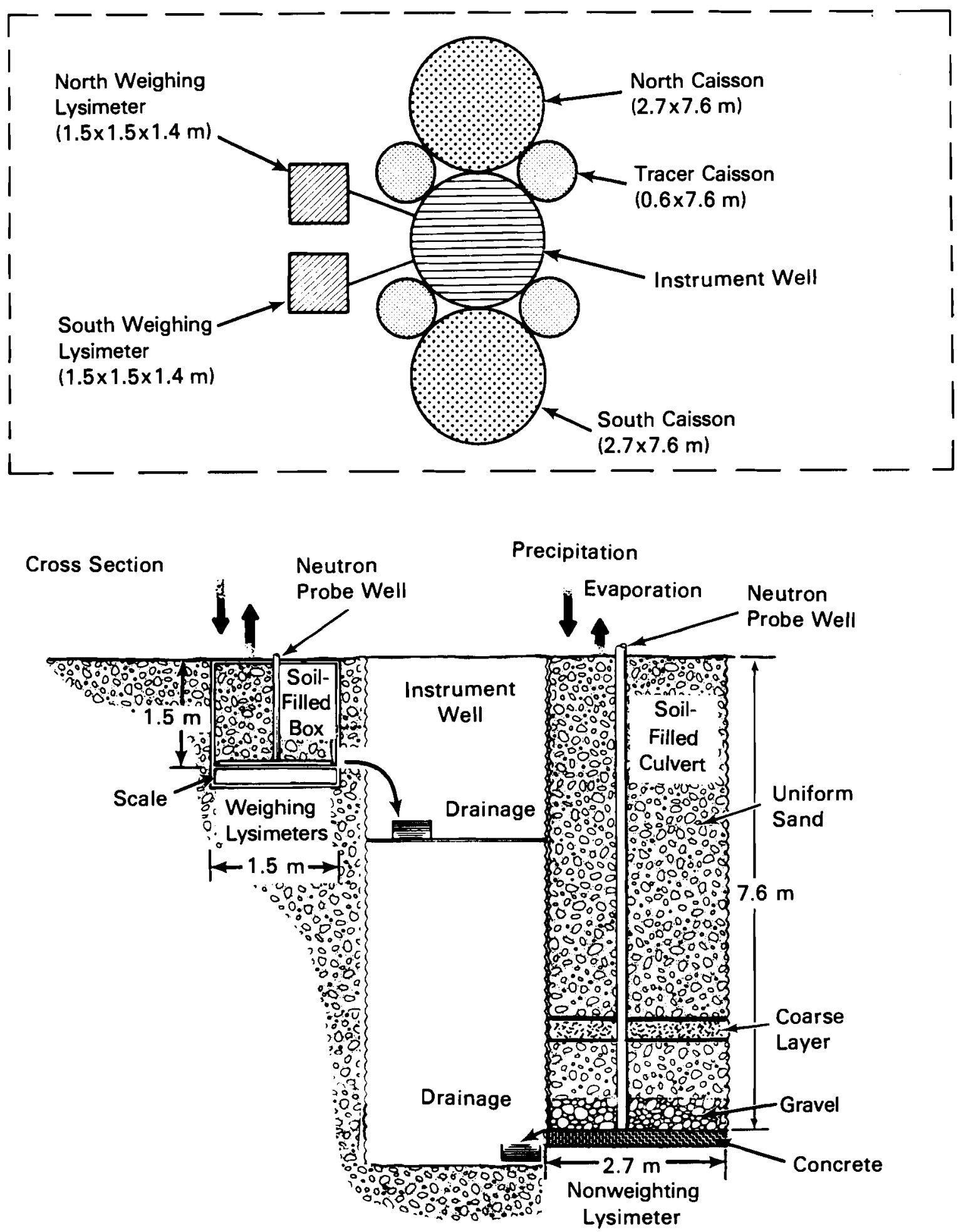

FIGURE 3.5. P7an View and Cross Section of the Buried Waste Test Facility Adjacent to the 300 North Burial Grounds 


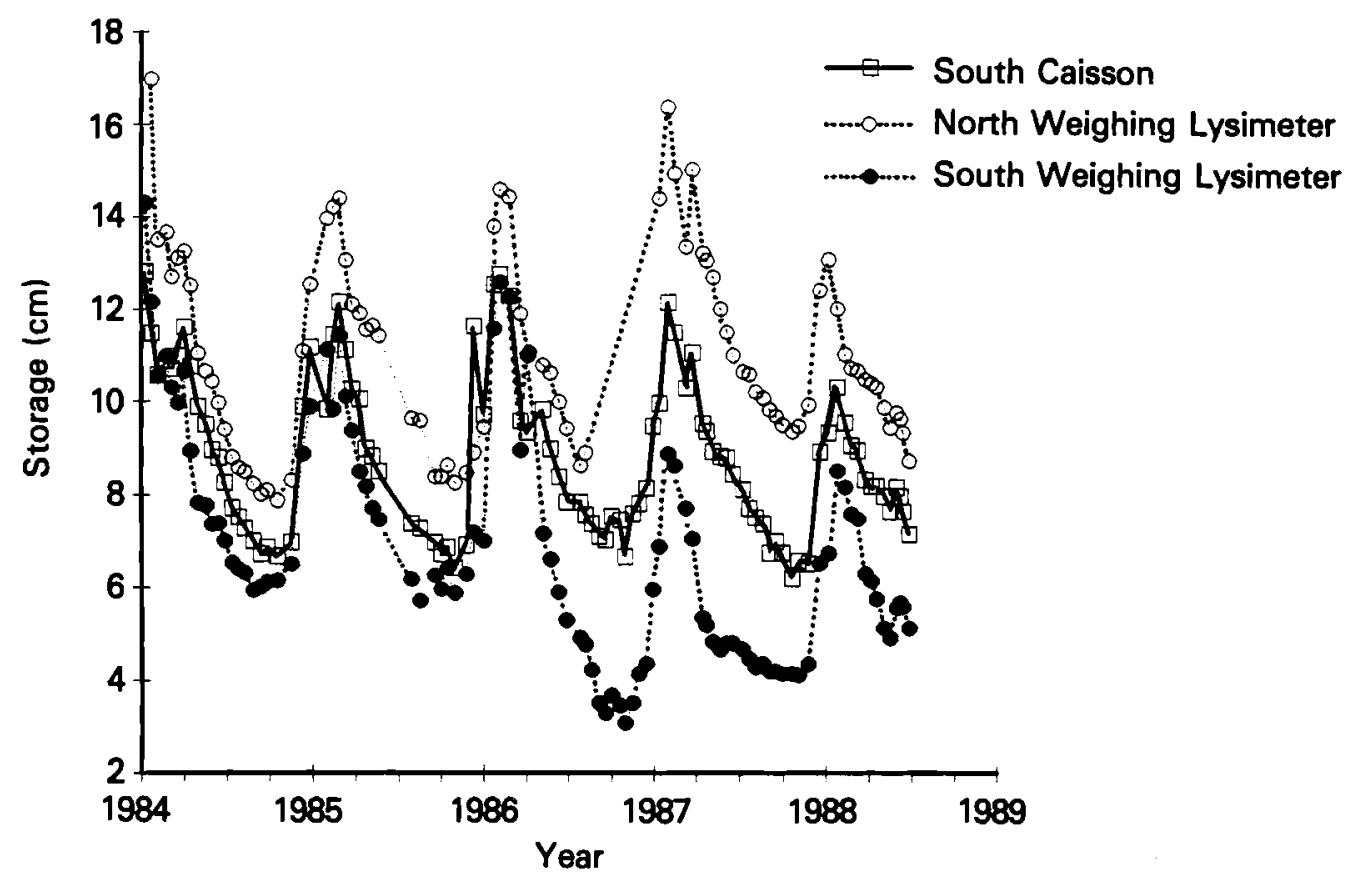

FIGURE 3.6. Water Storage in the Top 1.2-m Depth of the South Caisson, South Weighing Lysimeter, and North Weighing Lysimeter at the Buried Waste Test Facility

than in 1987, reflecting variations in winter precipitation from 1987 to 1988. Water-storage losses have persisted in all lysimeters since early spring (1988). For 1984 through 1988, the south weighing lysimeter consistently stored less water in the top $1.2 \mathrm{~m}$ of the soil profile than the other two lysimeters. This result is attributed to vegetative cover on the south weighing lysimeter and bare surfaces (no vegetation) on the other two lysimeters.

Both the south caisson and the north weighing lysimeter have drained during the past year (1987) (see Section 2.0). There has been no drainage from the south weighing lysimeter. The storage changes reflect the composite effect of precipitation, evaporation, and drainage. Water balance calculations using the surface storage data from these lysimeters are presented in Section 6.0. 


\subsection{THE 200 EAST LYSIMETER SITE}

The purpose of renewed monitoring of the 200 East $7 y$ simeter site is to thoroughly document current water storage changes at a 200 Area site under controlled surface (bare soil) conditions. Monitoring will permit testing of the hypothesis that removing vegetation from soil surfaces will enhance water storage and possibly lead to drainage at 200 Area waste burial sites. Monitoring planned for this lysimeter site during the next 2 years (1988 through 1989) will consist of at least monthly measurements of water storage in the closed-bottom lysimeter (nonvegetated soil) and in surrounding, undisturbed areas (vegetated soils).

Figure 3.7 shows the plan view of the 200 East lysimeter site and the cross section of the 18.5 -m-deep closed-bottom lysimeter. The open-bottom lysimeter, originally emplaced at this site early in 1972, was partially emptied (to a depth of about $6 \mathrm{~m}$ ) in the spring of 1983. The soil from this excavation, plus additional soil from an excavation immediately surrounding the lysimeter (Figure 3.8), was placed in a large stockpile immediately north of the open-bottom lysimeter. No effective attempt was made to stabilize the soil pile. As a consequence, since 1983, material blown from the pile has accumulated on the surface of the closed-bottom lysimeter. The open-bottom lysimeter is not presently used for soil-water monitoring.

Five neutron probe access tubes are currently being monitored at the 200 East lysimeter site. As shown in Figure 3.7, three of these access tubes are in the closed-bottom lysimeter. The fourth tube is in an area southwest of the lysimeters dominated by sagebrush (Artemisia tridentata). The fifth tube is in an area dominated by grass (Bromus tectorum), immediately south of the closed-bottom lysimeter. On January 22, 1988, the surface of the closedbottom lysimeter was observed to be covered to a depth of $40 \mathrm{~cm}$ with eolian (windblown) material, apparently from the stockpile located north of the open-bottom 7ysimeter. Surface vegetation, mostly annual grasses and weeds, was also observed (Figure 3.9). 
Site Coordinates

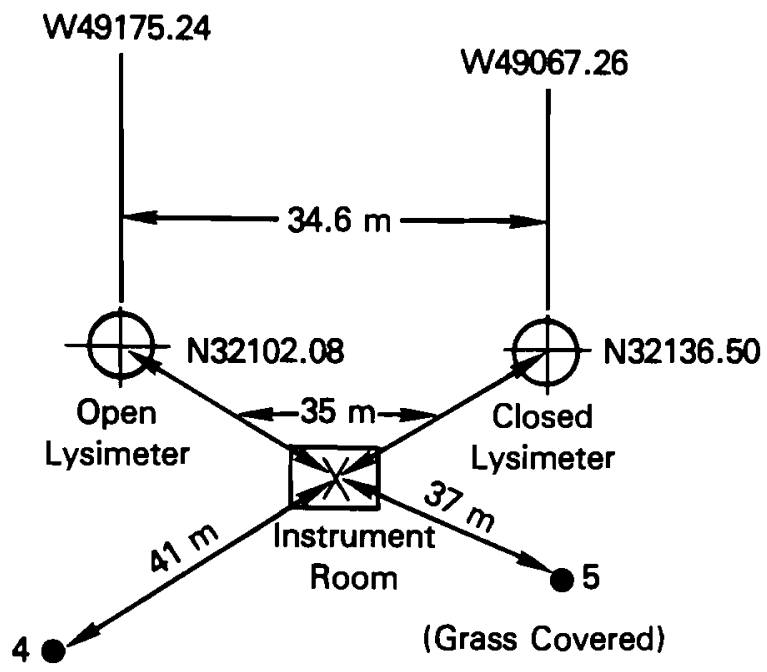

Closed-Bottom Lysimeter Surface

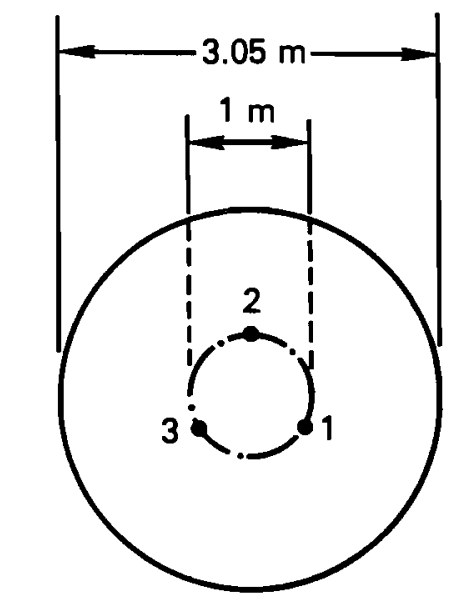

- Neutron Probe Access Tubes

(Sagebrush Covered)

Plan View

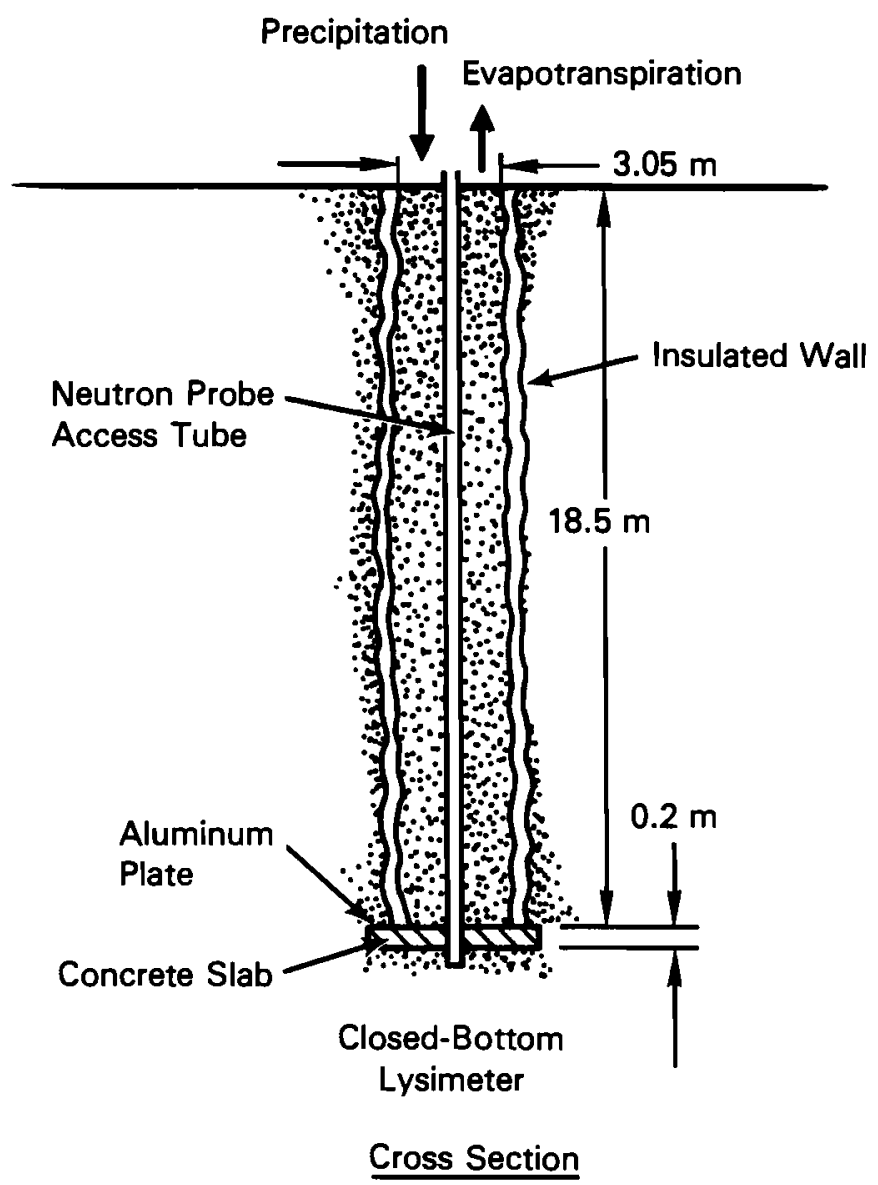

FIGURE 3.7. Plan View and Cross Section of 200 East Area Closed-Bottom Lysimeter 


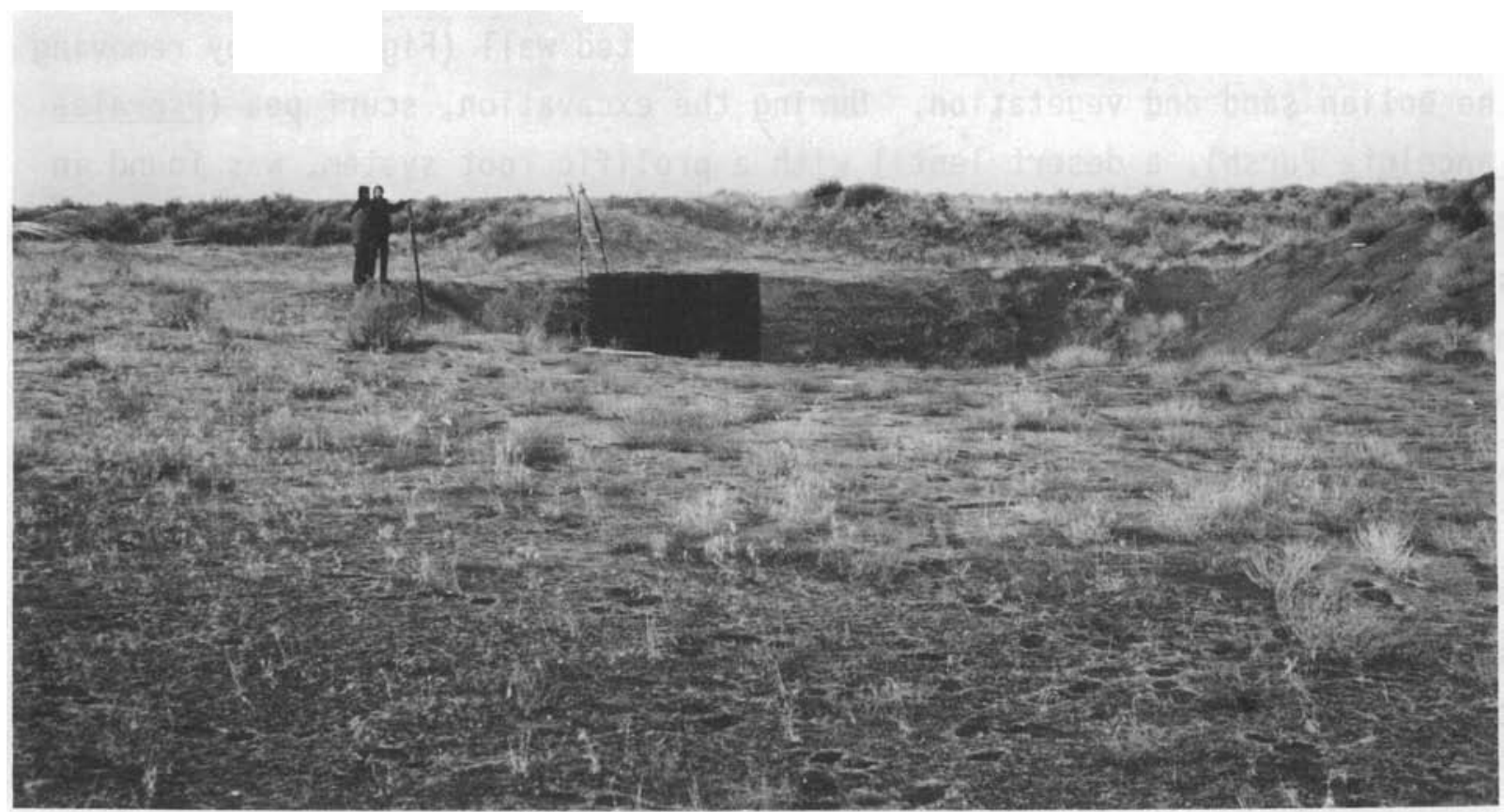

FIGURE 3.8. Excavation Site near the 200 East Open-Bottom Lysimeter on January 22, 1988

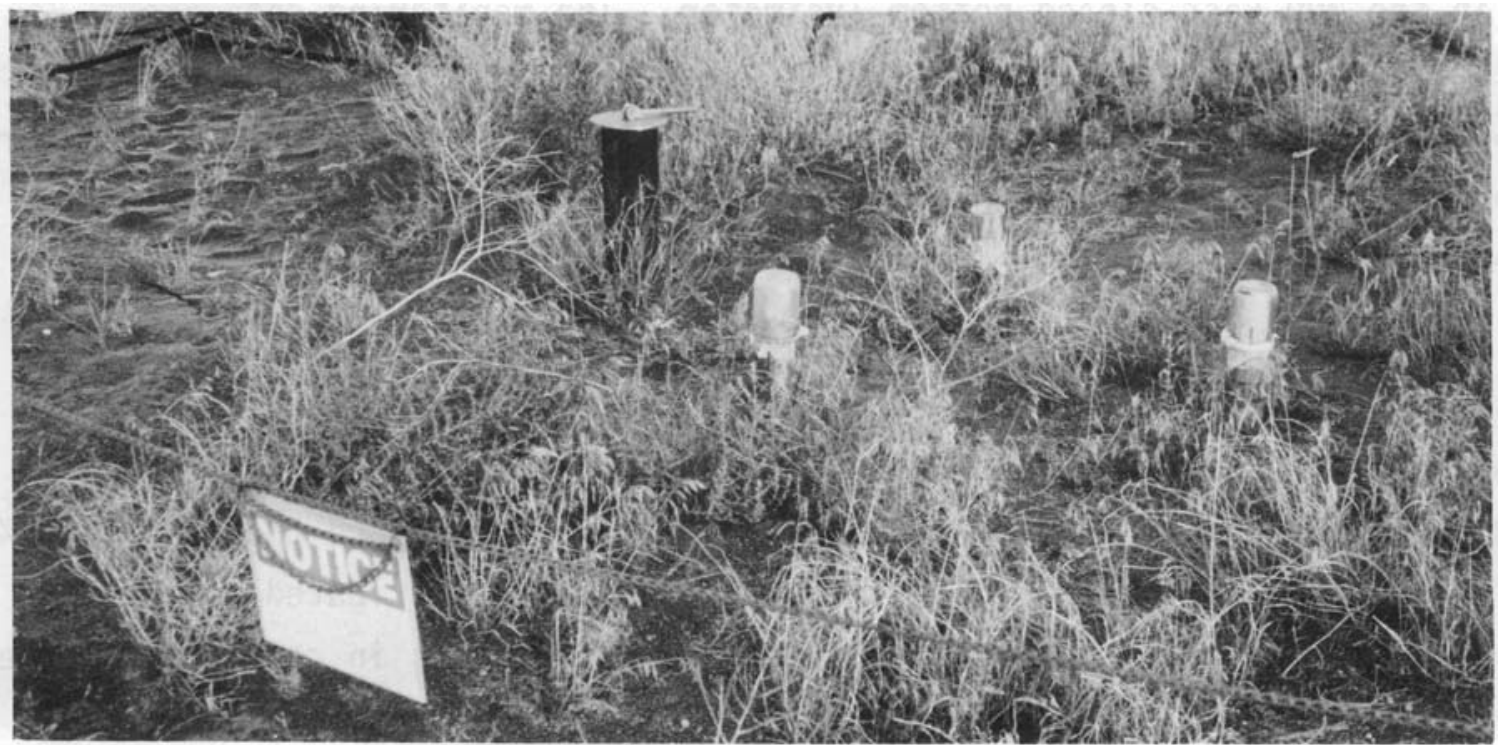

FIGURE 3.9. Surface of 200 East Closed-Bottom Lysimeter on January 22, 1988 
On February 4, 1988, the surface of the closed-bottom lysimeter was excavated down to the metal rim of the insulated wall (Fig. 3.7) by removing the eolian sand and vegetation. During the excavation, scurf pea (Psoralea lancelota Pursh), a desert lentil with a prolific root system, was found in abundance in and around the lysimeter. All vegetation was removed from the surface of the lysimeter, and monitoring of moisture was initiated using a neutron probe. Since February 1988, the three access tubes in the closedbottom lysimeter and the fourth and fifth access tubes in the sagebrush (Figure 3.10) and grassy areas (Figure 3.11) have been monitored bimonthly.

Water content profiles of the closed-bottom lysimeter are shown in Figures 3.12 and 3.13. A comparison of water storage measurements for all five access tubes is presented in Figure 3.14. The data show that water-storage changes are significantly less for the lysimeter than for the adjacent undisturbed areas. The effect of vegetation removal on water storage is apparent, with the closed-bottom lysimeter losing less than $1 \mathrm{~cm}$ of storage over a 6 -month period while more than $3 \mathrm{~cm}$ of water was lost from the vegetated (grass and sagebrush covered) sites.

The 200 East lysimeter will continue to be monitored through 1990 . Because of vegetation removal, water storage is expected to increase with time in the 200 East closed-bottom lysimeter. The monitoring data are expected to confirm earlier work (Fayer, Gee, and Jones 1986) that suggests the presence of plants on the surface of the 200 East lysimeters is the major reason for differences between storage and drainage data from the 200 East closed-bottom lysimeter monitored in the 300 Area.

Figure 3.12 shows the water content profile as measured to a depth of $18.5 \mathrm{~m}$ by the three neutron probes within the closed-bottom lysimeter. Except for measurements at a depth of $18 \mathrm{~m}$, there is reasonable agreement among the three samples; water contents seldom differ by more than \pm 0.5 vol\% moisture throughout the profile. The peak at $18 \mathrm{~m}$ is attributed to the concrete bottom of the closed-bottom lysimeter. Differences in readings for the three tubes are attributed to positioning of the probes and possibly to 


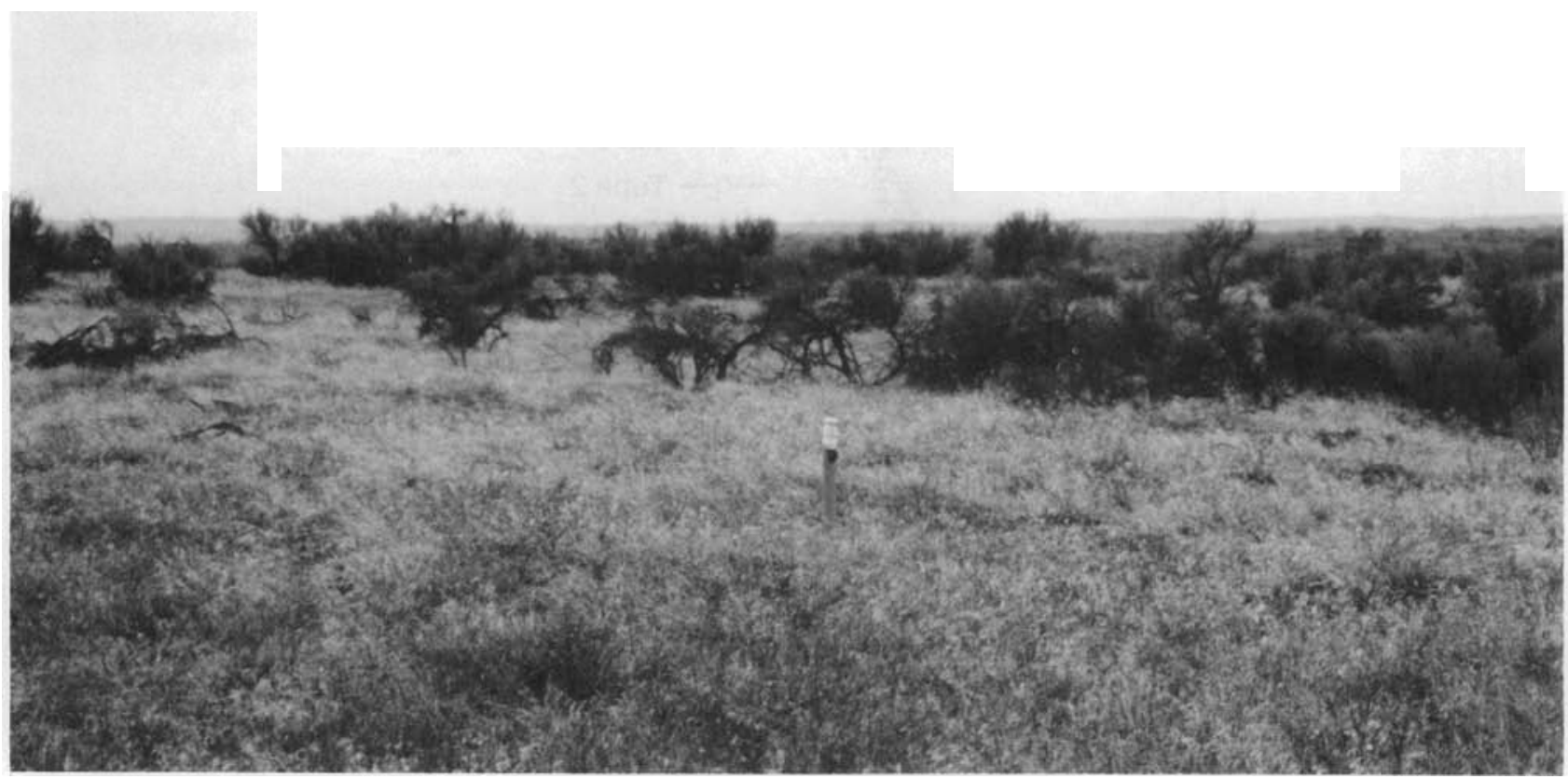

FIGURE 3.10. Access Tube \#4 Located in Sagebrush Cover South of the 200 East Closed-Bottom Lysimeter

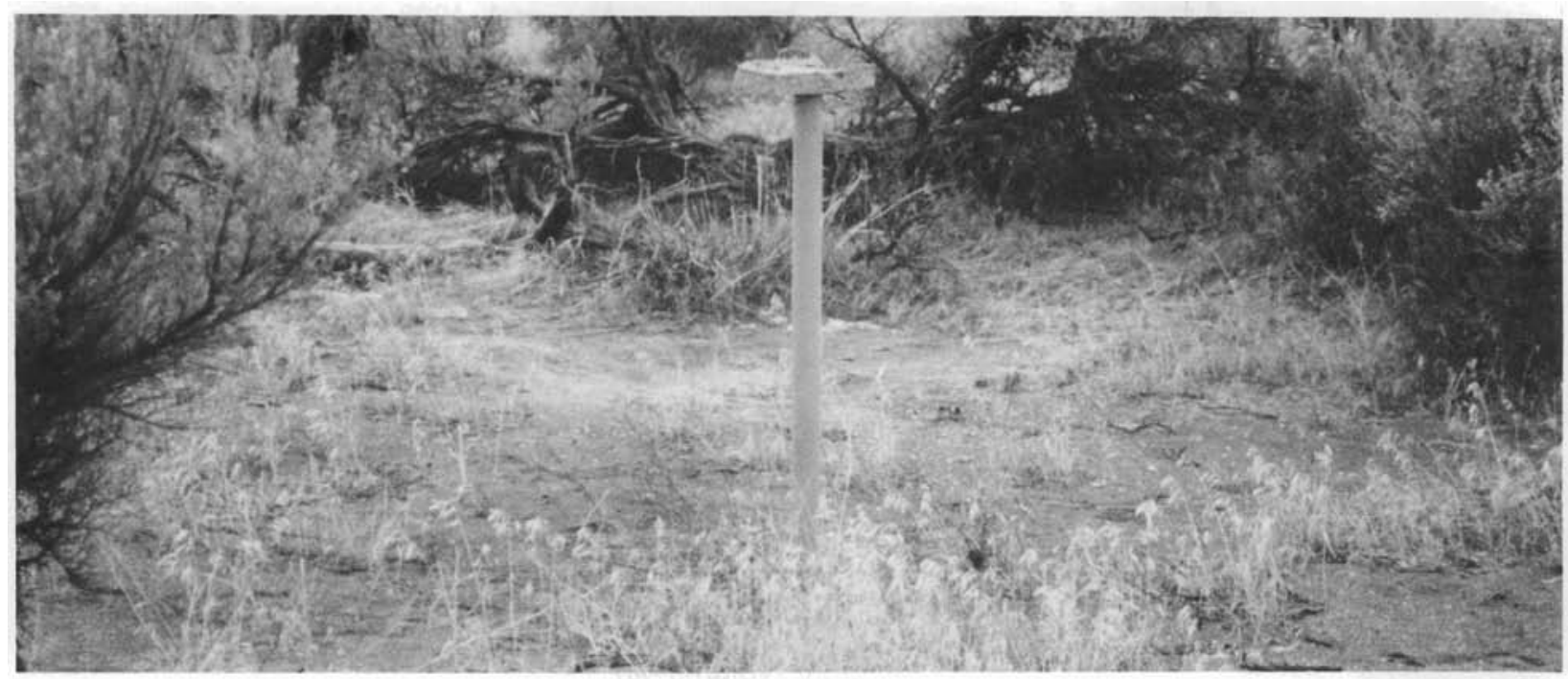

FIGURE 3.11. Access Tube \#5 Located in Grass Cover South of the 200 East Closed-Bottom Lysimeter 


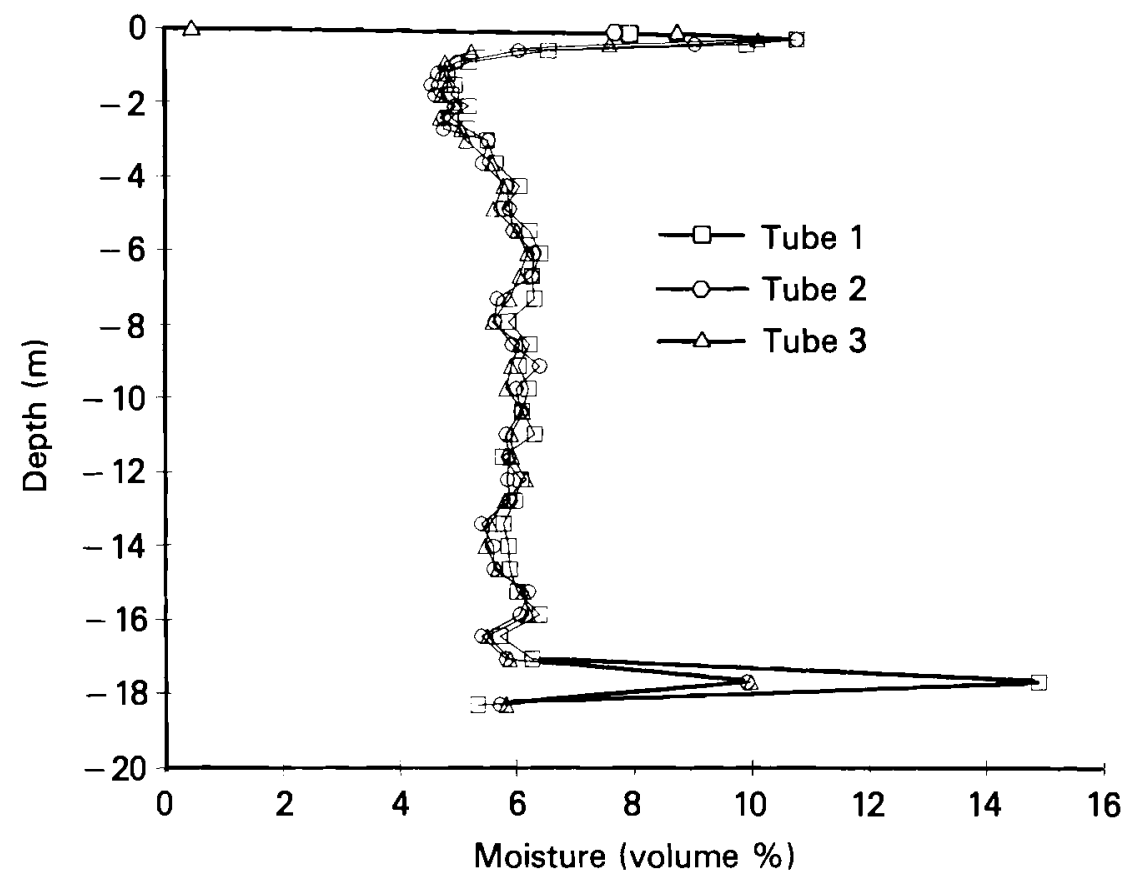

FIGURE 3.12. Water Content Profile at the 200 East Lysimeter Site for February 11, 1988 (a11 three access tubes were monitored)

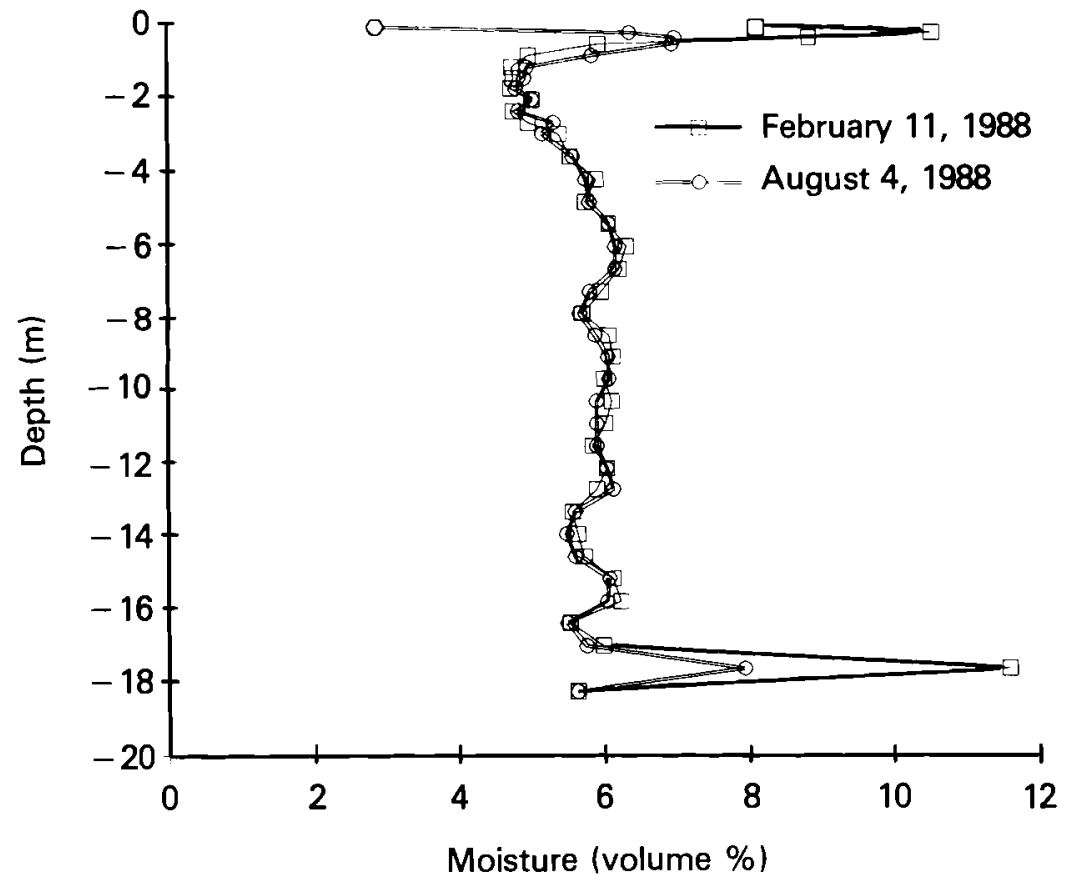

FIGURE 3.13. Water Content Profile at the 200 East Lysimeter Site (average for February 11, 1988, and August 4, 1988) 


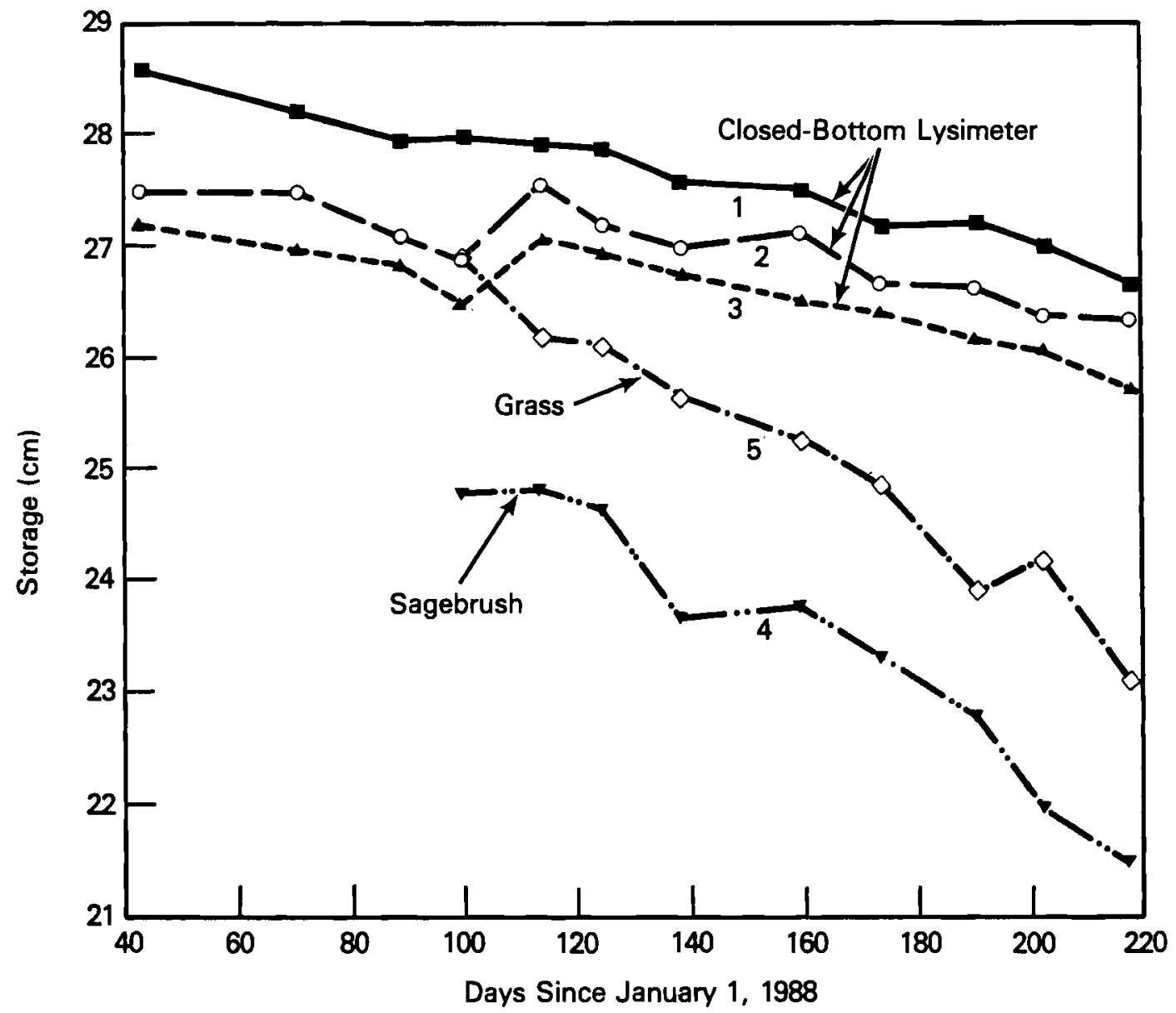

FIGURE 3.14. Soil-Water Storage in the Top $5 \mathrm{~m}$ of the Soil Profile as a Function of Time for Closed-Bottom Lysimeter and Adjacent Vegetated Areas at the 200 East Lysimeter Site

differences in the thickness of the concrete. Moisture at the lower depths is measured in $0.6-\mathrm{m}$ increments. The use of smaller increments would help resolve the apparent differences in water storage near the concrete slab at the bottom of the lysimeter.

Future measurements in the lysimeter will be taken over smaller increments $(0.3 \mathrm{~m}$ or less) in the bottom $1.2 \mathrm{~m}$ of the lysimeter to better define total storage and eliminate the uncertainties associated with measurements in and around the concrete bottom. 


\subsection{DRAINAGE}

Drainage was measured directly from lysimeters located in the 300 North Area (see Figure 1.2). In addition, two small gravel-covered lysimeters were constructed and placed at a test facility adjacent to the HMS to quantify the effects of a gravel surface on drainage.

\subsection{LYSIMETER DATA}

During the past year, drainage measurements were obtained from lysimeters at the BWTF (see Figures 1.1 and 3.5). Appendix D includes the procedure used in collecting data from the BWTF. (Figure D.1) and an example data sheet (Figure D.2). Cumulative drainage values from January 1984 through June 1988 for the south caisson, the south weighing 7ysimeter, and the north weighing lysimeter, are shown in Figures 4.1 and 4.2 and are listed in Appendix D (Tables D.1, D.2, and D.3).

From July 1987 through June 1988, there was no drainage from the south weighing lysimeter, which is covered with vegetation. Drainage occurred from the bare soils in the south caisson and north weighing lysimeter, but at rates lower than observed in previous years. The recent data reflect effects of vegetation and decreased winter precipitation on drainage (see Section 2.0). Table 4.1 summarizes the amount of annual drainage measured in the three BWTF 1ysimeters since July 1985. For comparison purposes, the average and standard deviation for annual drainage from 10 lysimeters at the adjacent CWTF(a) are also listed.

(a) The CWTF consists of 10 1ysimeters (1.8-m dia. by $3.1-\mathrm{m}$ deep), each of which contain a solidified commercial waste container surrounded by soil (Wa7ter, Graham, and Gee 1984; Jones, Serne, and Toste 1988). The facility is used to study the hydrology and geochemistry related to burial of solid wastes under arid climatic conditions. The operation of the facility is currently funded by the Special Waste Form LysimeterArid Task as part of the U.S. Department of Energy (DOE) Low-Level Waste Management Program. The facility is adjacent to and within $20 \mathrm{~m}$ of the BWTF. Similarities between the BWTF and CWTF are the climate and soil type. The soils in both facilities have similar textures $(>90 \%$ sand by weight). All 10 of the CWTF lysimeters have been kept bare (free of vegetation) since installation in 1984. 


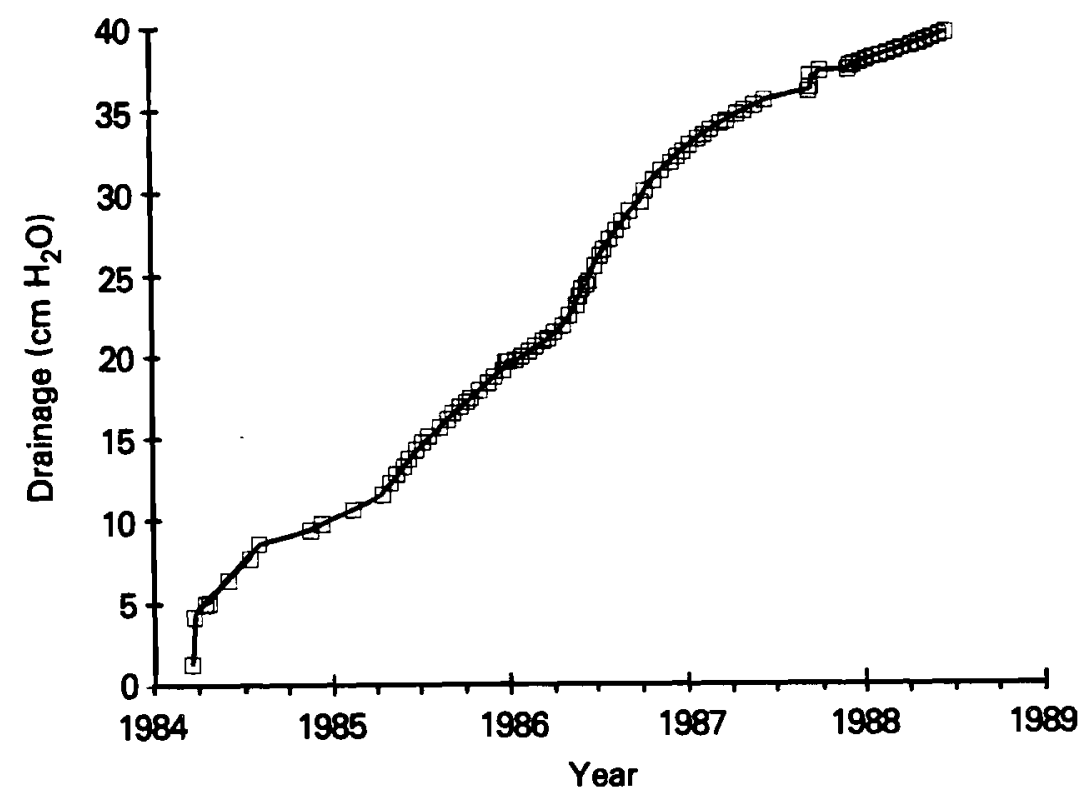

FIGURE 4.1. Cumulative Drainage from the South Caisson at the Buried Waste Test Facility

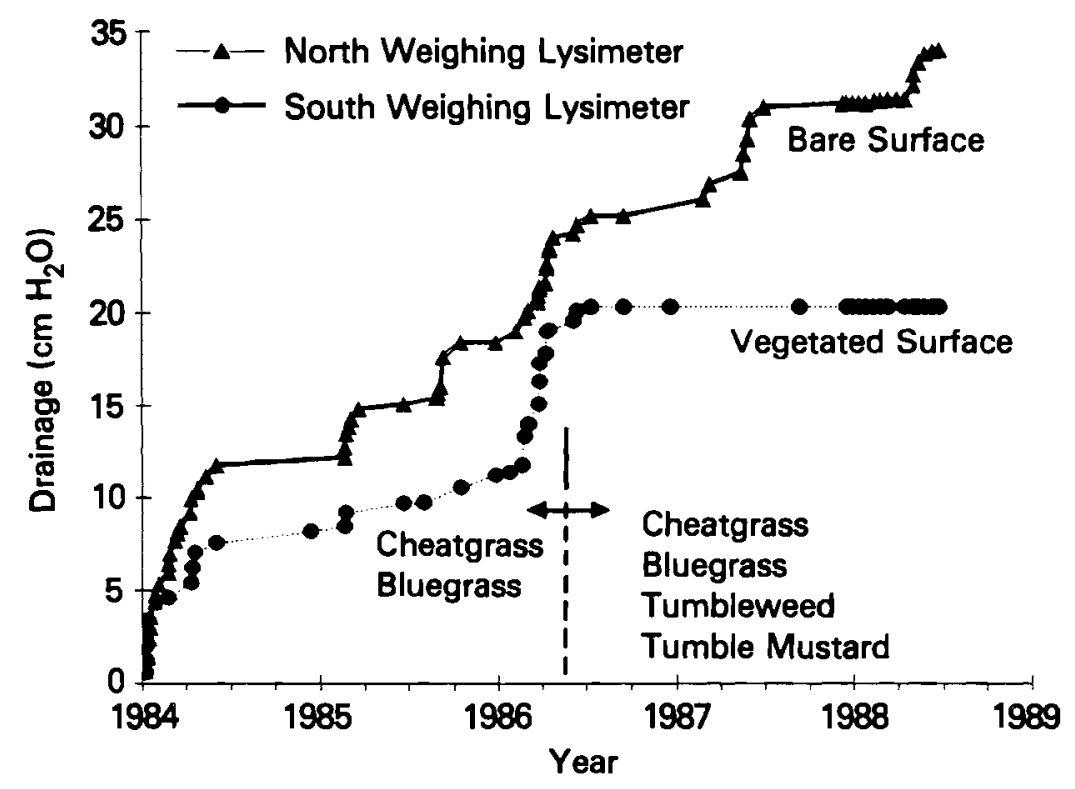

FIGURE 4.2. Cumulative Drainage for the North and South Weighing Lysimeters at the Buried Waste Test Facility 
TABLE 4.1. Drainage Data for Three Lysimeters at the Buried Waste Test Facility [South Weighing Lysimeter (SWL), North Weighing Lysimeter (NWL), and South Cassion (SC) ] and 10 Lysimeters (averaged values) at the Commercial Waste Test Facility (CWTF)

\begin{tabular}{|c|c|c|c|c|}
\hline Year & \multicolumn{4}{|c|}{ Lysimeter Drainage, $\mathrm{cm} \mathrm{H}_{2} \mathrm{O}$} \\
\hline (July-June) & $\overline{\text { SWL }}$ & NWL & $\mathrm{SC}$ & CWTF \\
\hline $1985-1986$ & 10.6 & 10.0 & 11.1 & $12.3 \pm 1.4$ \\
\hline $1986-1987$ & 0.1 & $6.0^{(a)}$ & 10.2 & $4.9 \pm 0.8$ \\
\hline $1987-1988$ & 0.0 & 3.1 & 4.0 & $4.6 \pm 0.4$ \\
\hline
\end{tabular}

(a) NWL was temporarily decommissioned from August 1986 to January 1987 (i.e., no drainage was collected for this time period).

Twelve bare-soil lysimeters (north weighing lysimeter, south caisson, and 10 lysimeters from the CWTF) exhibited similar high drainage rates (10 to $12 \mathrm{~cm} / \mathrm{yr}$ ) during the 1985 water year (July through June) and consistent7y lower drainage rates ( 3 to $5 \mathrm{~cm} / \mathrm{yr}$ ) during the 1987 water year. During 1986, a leak was detected in the north weighing lysimeter; it was excavated (and remained empty for 4 months, August through December 1986), resealed, and refilled in January 1987 . The data reported for this lysimeter is biased because of this disruption. The water storage and water contents of the refilled north weighing lysimeter (see Section 3.0, Figure 3.6) were higher than the other two BWTF lysimeters because the north weighing lysimeter was filled in January while the soil contained more moisture (6 to $8 \mathrm{wt} \%$ ) than the typical "field capacity" (4 to 5 wt\%). The excess water in this soil has subsequent7y drained or evaporated during the past 18 months. Drainage values from the north weighing lysimeter should not reflect the influence of climatic variables.

Drainage from the south caisson, which is the longest drainage lysimeter (7.6 $\mathrm{m}$ deep), was over twice that for the CWTF during the 1986 water year. This difference in drainage was 1ikely the result of extra storage water draining from the deeper south caisson. Nevertheless, the data are convincing evidence that drainage occurs in measurable quantities at this location 
because, when soils are kept bare, coarse-textured soils drain below the surface so readily that drainage occurs even in dry years.

A vegetative cover, primarily cheatgrass and bluegrass (poa), was established on the south weighing lysimeter in March 1983 (Gee 1987). Cheatgrass and bluegrass remained the dominant cover plants until 1986, when a large tumbleweed was allowed to grow on the lysimeter. Tumble mustard, an annual deep-rooted plant, invaded the surface of the lysimeter, germinated, and grew during the summers of 1987 and 1988 . Table 4.2 lists the observed surface cover conditions of the south weighing lysimeter since installation in 1979.

Tumbleweed and tumble mustard have relatively deep (generally in excess of $1 \mathrm{~m}$ vertical depth) tap roots and grow during summer months, as compared to cheatgrass and bluegrass, which are "cool season" grasses that become dormant in the summer. These differences in plant phenology (i.e., growth

TABLE 4.2. Surface Conditions of South Weighing Lysimeter at the Buried Waste Test Facility. Plant cover $(\mathrm{a})$ and density are listed.

Year Surface Condition

1979 Bare

1980 Bare

1981 Bare

1982 Bare

1983 Cheatgrass and bluegrass (transplanted, $-40 \%$ cover)

1984 Cheatgrass, bluegrass ( $-50 \%$ cover)

1985 Cheatgrass, bluegrass ( $-50 \%$ cover)

1986 Cheatgrass, bluegrass, tumbleweed ( $60 \%$ cover)

1987 Cheatgrass, bluegrass, tumble mustard ( $75 \%$ cover)

1988 Cheatgrass, bluegrass, tumble mustard ( $-60 \%$ cover)

(a) Scientific Name

Bromus tectorum

Poa sandbergii

Salsola kali

Sisymbrium altissimum
Common Name

Cheatgrass

Sandberg's bluegrass

Russian thistle (tumbleweed)

Jim Hill mustard (tumble mustard) 
patterns) are probable reasons why water losses from drainage were significantly reduced in the south weighing lysimeter during 1987 and 1988 (Figure 4.1 and Table 4.1). The observed large drainage from the south weighing lysimeter during the 1985-1986 water year is attributed to the release of stored soil water from winter rain accumulations. Water apparently infiltrated the soil profile below the shallow root systems of the cheatgrass and bluegrass during the winter months and could not be removed by capillarity or plant uptake at a rate fast enough to prevent drainage.

As discussed in Section 3.0 (Figure 3.6), the south weighing lysimeter stored significantly less water (in the top $1.2 \mathrm{~m}$ ) during the past years than did the other two (bare) lysimeters, thus reflecting the influence of water removal in summer months by deep-rooted plants (e.g., tumbleweed and tumble mustard). The lack of drainage is consistent with the lower storage values observed in the south weighing lysimeter.

Because effects of $\mathrm{plant}$ cover on drainage from the south weighing lysimeter are based only on a time series of single location, nonreplicated treatments, plant cover effects on drainage (localized recharge) for the entire Hanford Site were not extrapolated. However, the data strongly suggest that where there are shallow-rooted plants, such as cheatgrass and bluegrass, with no tumbleweed or other deep-rooted plants, there is high probability that drainage will occur, particularly when the soil is coarse textured, as it is in the south weighing lysimeter. Evidence that drainage can occur below vegetation at the Hanford Site is documented with the south weighing lysimeter data. Evidence that drainage can be eliminated by the presence of deep-rooted vegetation is also documented for the same location.

Predictive models for recharge that do not account for plant cover and rooting depth variations (either spatially or temporally) will not be successful for the Hanford Site. Vegetation dynamics, as influenced by such things as natural (i.e., fire, drought, etc.) or human disturbances (excavations, weed control, etc.), must be a key component in any reliable estimate for recharge at a specific location. Additional replicated tests that document drainage rates under vegetated conditions would be highly desirable. Tests have been proposed to use sma11-tube lysimeters at the Grass Site to 
directly measure drainage rates under conditions where shallow-rooted grasses grow on coarse-textured soils. Details related to small-tube lysimeter design (dimensions etc.) are presented in the following section.

\subsection{GRAVEL-COVERED LYSIMETERS}

During FY 1988, it was proposed to Westinghouse Hanford Company to study natural recharge at tank farm sites in the 200 Areas. Pacific Northwest Laboratory proposed to install small drainage-type lysimeters at a selected tank farm site and to monitor the lysimeters routinely (at least monthly) for weight change and drainage. The lysimeter data would then be used to estimate current recharge rates at the tank farm site. However, there were some concerns about radiation safety in excavating a site for locating the lysimeters and also in ensuring the accessibility of the lysimeters at the tank farms. Approval was given to construct lysimeters with gravel covers and locate them on the 200 Area Plateau under simulated tank farm conditions, thus minimizing radiation safety concerns and providing ready access to the lysimeters for monitoring. Subsequently, two lysimeters were constructed and located at a site close to the HMS.

Two smal1-tube (30.5-cm dia.), gravel-covered-type lysimeters were installed at an experimental plot located next to the Field Lysimeter Test Facility (FLTF) and adjacent to the HMS (Kirkham, Gee, and Downs 1987). The dimensions and layering sequence for the gravel-covered lysimeters are shown in Figure 4.3.

Lysimeters were constructed from 1.7-m long, plastic well casing manufactured by Corro-Tec, Inc., of Seattle, Washington. The casing was sealed at the bottom with a plastic insert that was welded to the casing. Each casing was fitted at the bottom with a drainage fitting coupled to a length of flexible plastic Tygon(a) tubing. A clamp was placed at the end of the tubing. Drainage water was collected from the outflow tube and measured. Each column was leak tested by filling the column with water to a depth of approximately $1 \mathrm{~m}$, allowing a minimum of $24 \mathrm{hr}$ to elapse, then checking

(a) Tygon is a registered tradename of U.S. Stoneware Company, Akron, Ohio. 


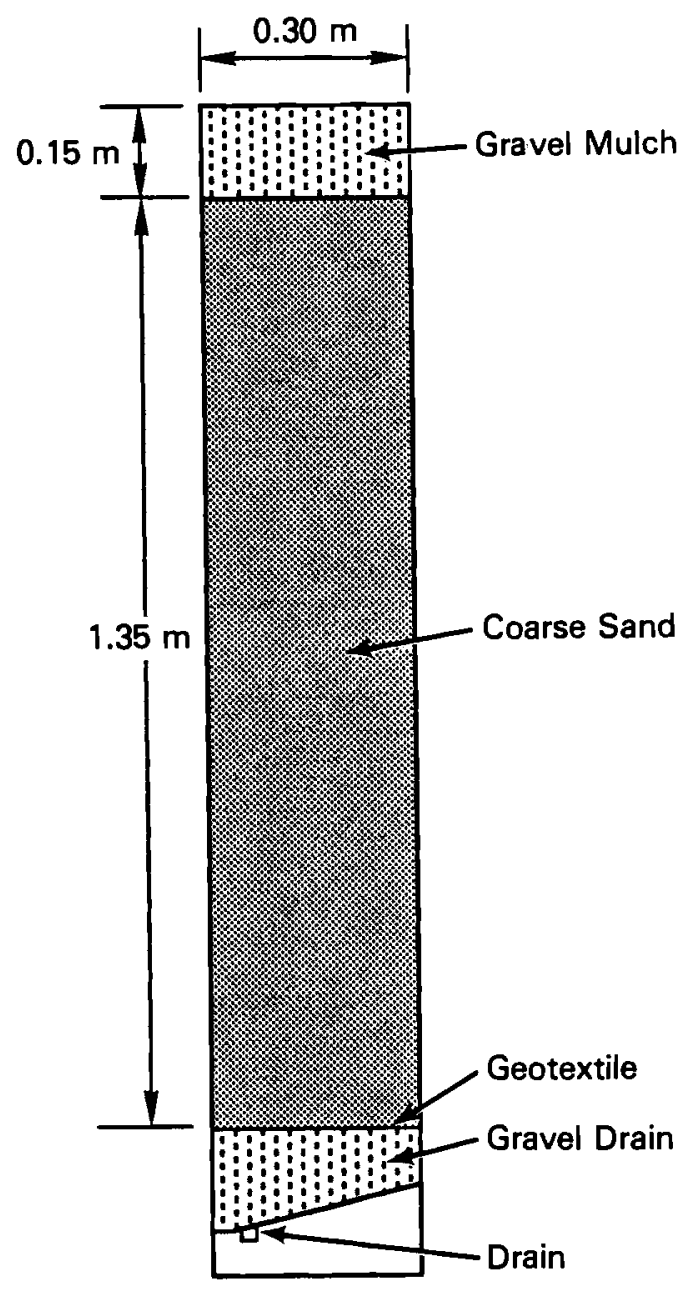

FIGURE 4.3. Schematic of Gravel-Covered Lysimeter Used to Simulate Tank Farm Surface Conditions

bottom seams and the area around the drainage fitting for signs of moisture. No leaks were observed from the welded seams in the bottom of the columns, but some fittings leaked. When leaks were detected, the fittings were readjusted and the leak test repeated until the leaks were stopped. Once the columns were leak free, the water was removed and a piece of heavy-duty screen was placed over the drain hole on the inside of the column to prevent plugging by gravel in the bottom layer.

The column was then filled with layers of gravel, geotextile, and sand, and topped with a layer of gravel (Figure 4.3). The bottom of the lysimeters were filled with $\sim 20 \mathrm{~cm}$ of gravel $(\sim 8-\mathrm{mm}$ dia) to facilitate collection of any drainage that may occur. The bottom grave 1 was covered by a geotextile to 
prevent the sand layer from sifting into the gravel layer. Coarse sand was packed on the geotextile in nine lifts that were $15 \mathrm{~cm}$ in length to a height of $135 \mathrm{~cm}$ above the geotextile and $15 \mathrm{~cm}$ from the top of the column. The average water content of the sand was $5 \mathrm{wt} \%$, and the soil was packed to an average dry bulk density of approximately $1.62 \mathrm{~g} / \mathrm{cm}^{3}\left(1.7 \mathrm{~g} / \mathrm{cm}^{3}\right.$ wet density). Grab samples of each lift were collected for determining moisture. The coarse sand was covered with a $15-\mathrm{cm}$-thick gravel layer to maximize infiltration. The grave1-covered lysimeters were put in place at the test facility on July 25, 1988. A small (2-ton capacity) crane and a crane scale, sensitive to $\pm 0.1 \mathrm{~kg}$, were used to position and weigh the lysimeters. Weights of the two lysimeters were documented for 2 days (July 25, 1988, and August 25,1988 ) (Table 4.3). Weights will be measured on at least a monthly basis. The weight changes and drainage rates from these two lysimeters will be documented and compared with other lysimeters that are being placed at this same site. The influence of gravel covers and the absence of vegetation on drainage will be documented for soil and climate conditions on the 200 Area Plateau.

TABLE 4.3. Grave1-Covered Lysimeter Weight Changes

\begin{tabular}{|c|c|c|}
\hline \multirow[b]{2}{*}{ Lysimeter } & \multicolumn{2}{|c|}{ Weight, $\mathrm{kg}$} \\
\hline & 25 July 1988 & 25 Aug 1988 \\
\hline$G-9$ & 230.3 & 229.8 \\
\hline$G-10$ & 229.7 & 229.2 \\
\hline
\end{tabular}




\subsection{HYDRAULIC PROPERTIES}

Several efforts have been made to obtain reliable estimates of hydraulic properties of Hanford Site soils for use in water balance calculations using computer codes such as UNSAT-H (Fayer, Gee, and Jones 1986). Field measurements of hydraulic conductivity were started at two locations in FY 1988 . In the Fall of 1987, two unsteady drainage flux-method experiments (Green, Ahuja, and Chong 1986) were conducted at the Grass Site and the McGee Ranch. Results of the first set of these experiments are reported by Rockhold, Fayer, and Gee (1988). The results of the second set of experiments are reported here.

In addition to the measurement of hydraulic conductivity at these two sites, water retention characteristics were measured and a fractal technique for parameter estimation was tested. Rockhold, Fayer, and Gee (1988) previously used the Arya and Paris (1981) model to predict water retention characteristics from particle-size distribution and bulk-density data. An estimation method using concepts of fractal mathematics is described in this section and used to estimate parameters in the Arya and Paris (1981) soilwater retention model for the Grass Site and McGee Ranch soils.

\subsection{UNSATURATED HYDRAULIC CONDUCTIVITY FOR THE GRASS SITE}

Calculations of hydraulic conductivity using the unsteady drainage-flux method are based on a one-dimensional Darcian analysis of transient, in situ soil-water content and hydraulic head profiles during vertical drainage from field plots. The method, as used in this study, consisted of ponding water on the surface of a plot until the soil profile was wetted beyond the maximum depth of interest. The soil surface was then covered with clear plastic and a thin (approximately $3-\mathrm{cm}-$ thick) layer of soil to prevent evaporation and minimize thermal effects. Isothermal conditions were assumed to exist in the profile during drainage. Water contents and hydraulic heads were then monitored as the water in the profiles redistributed and drained. Specific details of measurements taken at the Grass Site and the McGee Ranch, and subsequent hydraulic conductivity calculations, are described by Rockhold, Fayer, and Gee (1988). 
Hydraulic head data from the first experiment at the Grass Site indicated that a significant amount of water moved laterally out of the test plot profile [see Figure 5.1(a)]. Therefore, an assumption that all water drains vertically, which is needed to correctly calculate hydraulic conductivities, assuming one-dimensional flow using Richards' equation (Richards 1931), is not valid. Consequently, the experiment was modified to eliminate lateral flow, and rerun.

As reported previously by Rockhold, Fayer, and Gee (1988), the soil profile at the Grass Site is layered, with approximately $45 \mathrm{~cm}$ of sandy loam overlying more than $3 \mathrm{~m}$ of relatively uniform coarse sand. This textural transition inhibits redistribution of water into the lower layer by restricting the downward flux to the extent that the lower layer cannot become completely saturated. This hydrologic barrier also acts to store water longer in the upper part of the soil profile. Under the conditions of the first experiment, where the surface was covered but only a finite area was wetted, water could apparently be drawn laterally out of the upper part of the soil profile by potential gradients from the drier surrounding soil, rather than draining into the lower part of the soil profile by gravity flow.

In the second experiment at the Grass Site, lateral flow out of the upper profile layer was eliminated by trenching around the perimeter of the plot down to a depth of $60 \mathrm{~cm}$ and installing plastic sheeting. The textural transition between the two soil layers occurs between the $45-$ and $60-\mathrm{cm}$ depths. The distance from the center of the wetted plot to the trench was approximately $1.5 \mathrm{~m}$. Soil was then backfilled and the experiment repeated. Hydraulic conductivities and profile storage changes were calculated using the data from both experiments to quantify the lateral flow effects in the first experiment and to determine the resulting effect on hydraulic conductivity calculations.

Figure 5.1(a) and (b) show the total hydraulic head profiles for the first and second experiments, respectively. Matric head data corresponding to these profiles are listed in Tables D.2 and D.6. Data shown in these figures indicate that lateral flow out of the upper part of the soil profile was effectively eliminated in the second experiment by the plastic sheeting. 

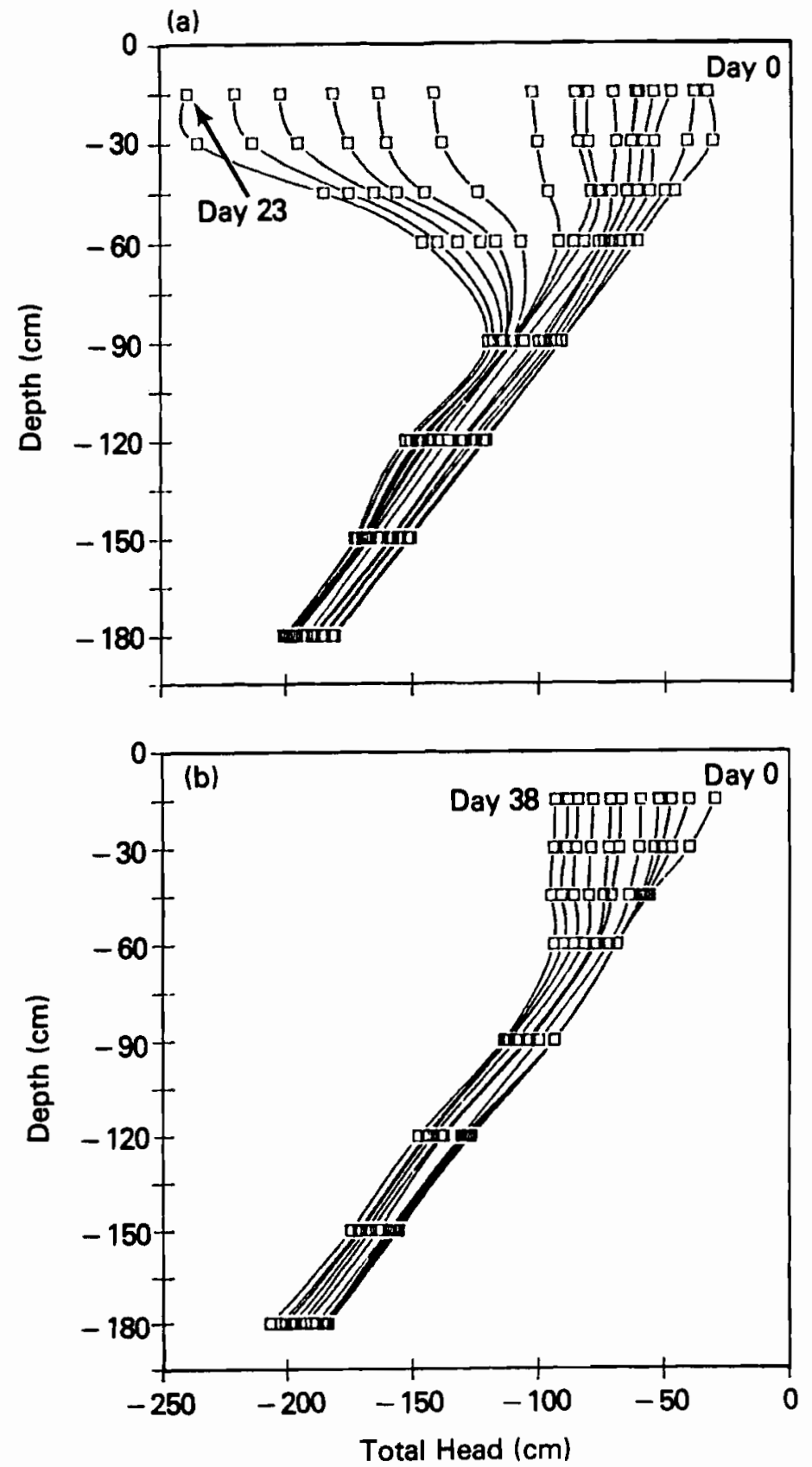

FIGURE 5.1. Total (matric plus gravity) Head Profiles for First and Second Experiments at the Grass Site. (a) Represents first experiment over a period of 23 days, with day 0 plot on right and day 23 plot on left. (b) Represents second experiment over a period of 38 days, with day 0 plot on right and day 38 plot on the left. 
In the second experiment, the range over which total head changed above the $60-\mathrm{cm}$ depth was still more than twice as great as the range over which total head changed below the $60-\mathrm{cm}$ depth. This result is likely due to different water retention characteristics of the upper, fine soil relative to the lower, coarse soil.

Figure 5.2(a) and (b) show water content profiles from the first and second experiment, respectively. These data are listed in Tables E.1 and E.5. The water content at the $30-\mathrm{cm}$ depth decreased by $0.083 \mathrm{~cm}^{3} / \mathrm{cm}^{3}$ in the first experiment (from $0.191 \mathrm{~cm}^{3} / \mathrm{cm}^{3}$ to $0.108 \mathrm{~cm}^{3} / \mathrm{cm}^{3}$ ) during approximately 23 days. This contrasts with the second experiment in which the water content at the $30-\mathrm{cm}$ depth decreased only by $0.045 \mathrm{~cm}^{3} / \mathrm{cm}^{3}$ (from $0.178 \mathrm{~cm}^{3} / \mathrm{cm}^{3}$ to $0.133 \mathrm{~cm}^{3} / \mathrm{cm}^{3}$ ) during approximately 38 days of drainage. Differences in water content changes at depths below $45 \mathrm{~cm}$ are comparable for both experiments. Based on this information and the hydraulic head profiles shown in Figure 5.1(a) and (b), lateral flow of water out of the upper part of the test plot profile in the first experiment appears to have been significant.

Total water storage in the soil profile was calculated for both experiments using a trapezoidal approximation (Green, Ahuja, and Chong 1986), assuming the water content at the surface was equal to the water content at the $15-\mathrm{cm}$ depth. The total water stored in the profile above a depth of $180 \mathrm{~cm}$ immediately after ponding was $26.75 \mathrm{~cm}$ in the first experiment and $26.09 \mathrm{~cm}$ in the second experiment. The total water stored in the profile after approximately 23 days of drainage and redistribution was $12.24 \mathrm{~cm}$ and $15.03 \mathrm{~cm}$, for the first and second experiments, respectively. Considering the differences between initial water storage for each experiment, the lateral flow apparently resulted in $3.45 \mathrm{~cm}$ more storage loss from the profile in the first experiment than in the second experiment. This value is approximately $24 \%$ of the total water storage change during the first experiment.

Water content and hydraulic head profiles were used to calculate hydrau1ic conductivities with a time-averaging approach, as described by Rockhold, Fayer, and Gee (1988). Calculated hydraulic conductivities for the first and second experiments are listed in Tables E.4 and E.8, respectively. 

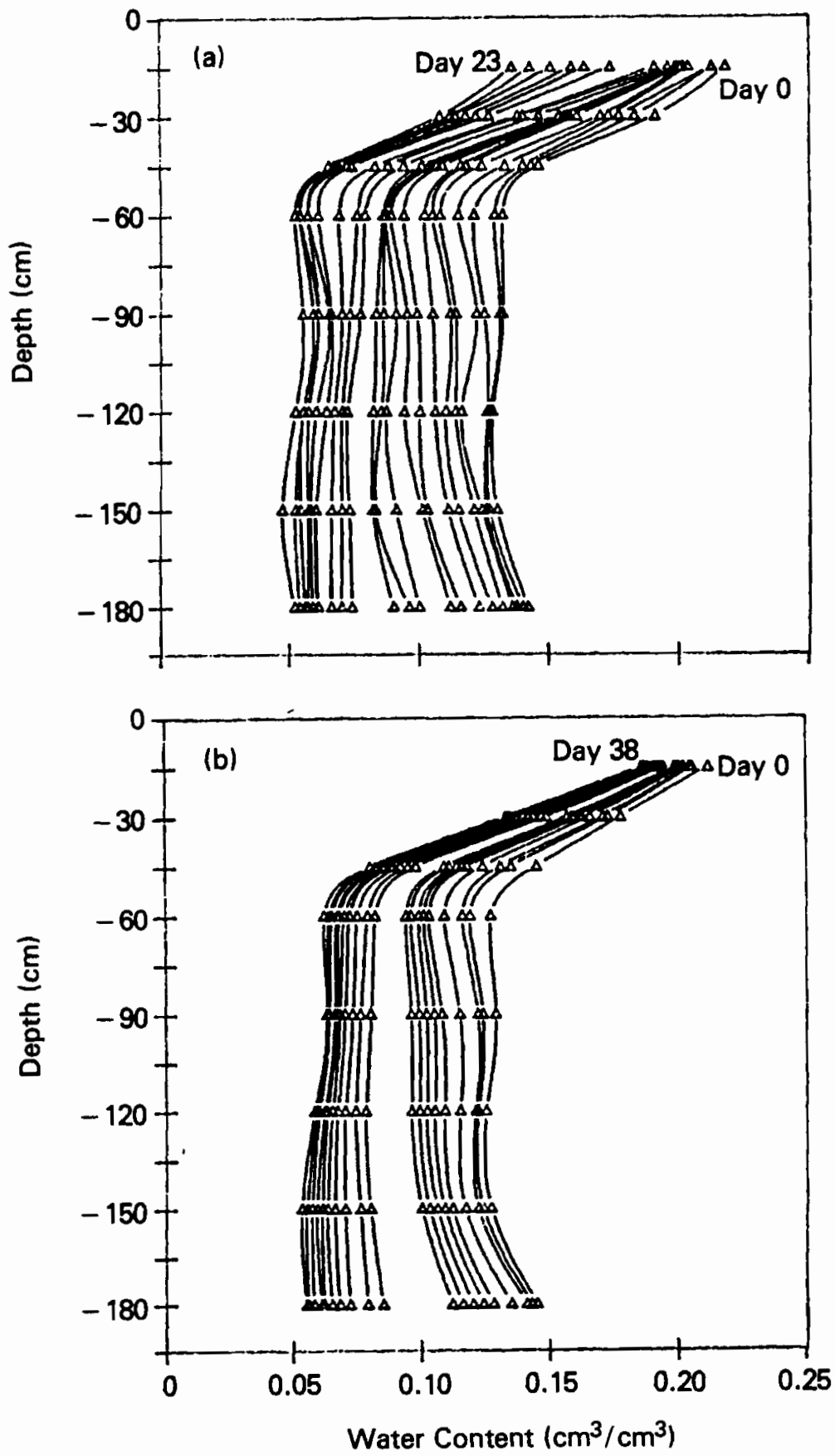

FIGURE 5.2. Water Content Profiles Measured with a Neutron Probe for First and Second Experiments at the Grass Site. (a) Represents first experiment over 23 days, with day 0 plot on right and day 23 on left. (b) Represents second experiment (restricted lateral

flow) over a period of 38 days, with day 0 plot on right and day 38 plot on left. 
Total head gradients were estimated with a two-sided approximation

$$
\partial H / \partial z \approx\left[h\left(\operatorname{depth}_{Z}+1, t\right)-h\left(\operatorname{depth}_{Z}-1, t\right) /\left(\operatorname{depth}_{Z}+1-\operatorname{depth}_{Z}-1\right)\right]-1
$$

where $H$ is the total hydraulic head, $h$ is the matric head at time $t$, and $z$ is the depth below soil surface.

Figure 5.3(a) and (b) show hydraulic conductivity as a function of volumetric water content for the $30-$ to $180-\mathrm{cm}$ depths, from the first and second experiments, respectively. Hydraulic conductivities from the upper part of the soil profile are not delineated as well in the first experiment as in the second because the reversal in head gradients (caused by lateral flow) resulted in negative conductivities. In the lower part of the soil profile, calculated hydraulic conductivities are up to one order of magnitude higher for the first experiment than for the second. This result is explained by calculations of hydraulic conductivities that assume storage changes above any given depth in a given time period result from water moving vertically downward. Thus, the higher hydraulic conductivities calculated from data of the first experiment reflect the larger changes in storage that result from lateral flow out of the profile, in addition to vertical flow through the profile, without corresponding changes in head gradients.

Figure 5.4 shows the water retention characteristics from the second experiment at the Grass Site. The data from the lower part of the soil profile (at $60-$ to $180-\mathrm{cm}$ depths) group together fairly closely compared to the data from the upper part of the soil profile (15- to $45-\mathrm{cm}$ depths). Data from the latter appear to have transitional water retention characteristics, but may actually represent points on scanning curves because they were wet up to different water contents during ponding. Observations from the trench dug around the plot at the study site for the second experiment show the textural transition from the upper soil layer to the coarser lower layer to be relatively abrupt. However, detailed particle-size analyses (see Table 5.1) indicate a textural gradation from the upper to the lower layer, which may explain the differences in water retention characteristics. 

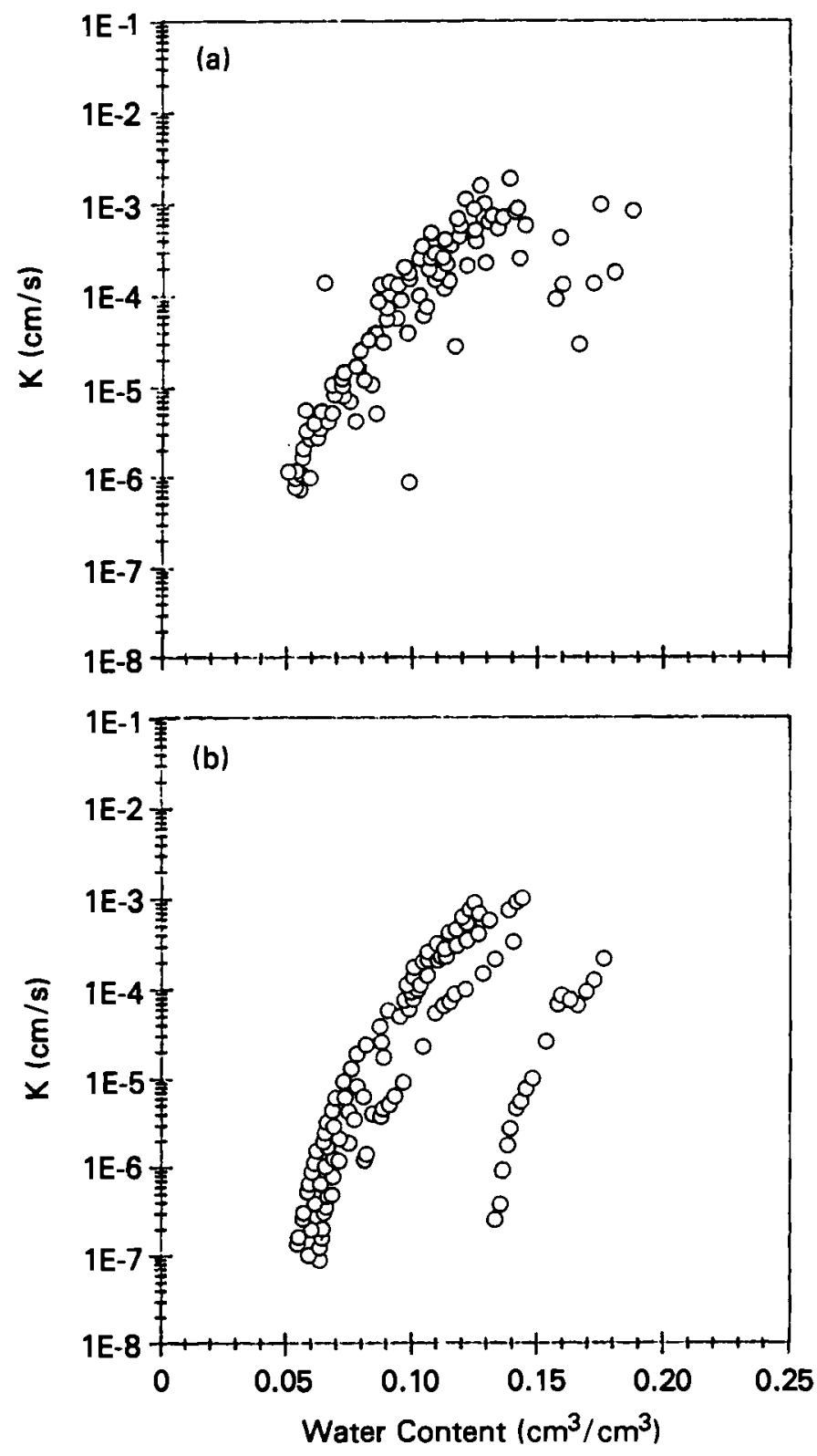

FIGURE 5.3. Comparison of Unsaturated Hydraulic Conductivity as a Function of Water Content for First and Second Experiments at the Grass Site (depth 30 to $180 \mathrm{~cm}$ ). (a) Represents first experiment and (b) represents second experiment (restricted lateral flow). 


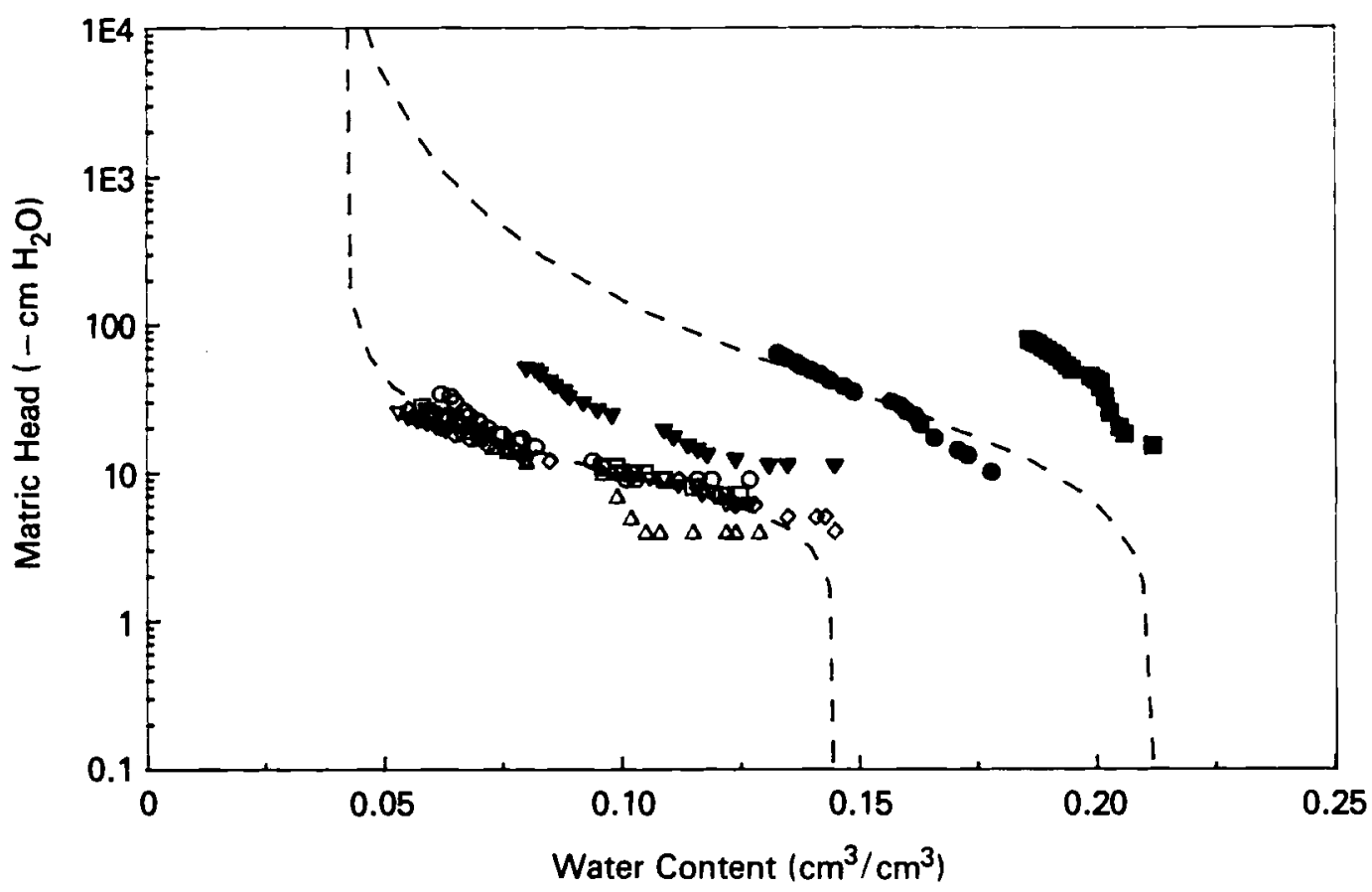

FIGURE 5.4. Water Retention Characteristics (matric head versus water content) for Second Experiment (restricted lateral flow) at the Grass Site. (A11 depths reported. Upper dashed 1 ine represents $30-\mathrm{cm}$ depth; lower dashed line represents 60 - to $180-\mathrm{cm}$ depths.)

TABLE 5.1 Grass Site Laboratory Particle-Size and Hydraulic Conductivity Data

\begin{tabular}{|c|c|c|c|c|}
\hline Depth $(\mathrm{cm})$ & $\%$ Sand & $\%$ silt & \% Clay & $\mathrm{K} 1 \mathrm{~s}(\mathrm{a})(\mathrm{cm} / \mathrm{s})$ \\
\hline $\begin{array}{r}0-15 \\
15-30 \\
30-40\end{array}$ & $\begin{array}{l}72 \\
77 \\
85\end{array}$ & $\begin{array}{l}22 \\
17 \\
10\end{array}$ & $\begin{array}{l}6 \\
6 \\
5\end{array}$ & $\begin{array}{l}1.25 \mathrm{E}-4 \\
6.23 \mathrm{E}-4 \\
3.69 \mathrm{E}-3\end{array}$ \\
\hline $\begin{array}{c}40-50 \\
50-60 \\
60-80 \\
80-90 \\
95\end{array}$ & $\begin{array}{l}90 \\
96 \\
96 \\
97 \\
94\end{array}$ & $\begin{array}{l}6 \\
2 \\
2 \\
1 \\
4\end{array}$ & $\begin{array}{l}4 \\
2 \\
2 \\
2 \\
2\end{array}$ & $\begin{array}{l}1.67 \mathrm{E}-3 \\
2.42 \mathrm{E}-3 \\
2.67 \mathrm{E}-3 \\
2.68 \mathrm{E}-3 \\
2.01 \mathrm{E}-3\end{array}$ \\
\hline
\end{tabular}

(a) Laboratory-saturated hydraulic conductivity determined by the falling head method (Klute and Dirksen 1986). 
To describe the water retention characteristics and hydraulic conductivity-water content relationships of this layered profile, the van Genuchten (1978) water retention model was fit to the data. These curves are shown in Figure 5.4. The differences between the water retention characteristics and calculated hydraulic conductivities from various depths within the profile necessitated separate curve fittings of data from the upper and lower soil profile. Because of uncertainties regarding the accuracy of hydraulic head approximations at $15 \mathrm{~cm}$ and the effects of the textural transition at $45 \mathrm{~cm}$, data from the $30-\mathrm{cm}$ depth were assumed to be the most representative of the upper part of the soil profile. Data from the 60to $180-\mathrm{cm}$ depths were fitted simultaneously to represent the lower part of the soil profile.

The residual water content values, $\theta_{r}$, were fixed at the initial (preponding) average water contents (i.e., $0.036 \mathrm{~cm}^{3} / \mathrm{cm}^{3}$ and $0.042 \mathrm{~cm}^{3} / \mathrm{cm}^{3}$ for the upper and lower parts of the profile, respectively). The saturated water contents, $\theta_{S}$, were fixed at the highest water contents obtained during the experiment (i.e., $0.212 \mathrm{~cm}^{3} / \mathrm{cm}^{3}$ and $0.145 \mathrm{~cm}^{3} / \mathrm{cm}^{3}$ for the upper and lower parts of the profile, respectively). The saturated hydraulic conductivity, $K_{s}$, was fixed for the entire profile at the infiltration rate of $2 E-3 \mathrm{~cm} / \mathrm{s}$. This value was measured immediately before the start of drainage (i.e., at time zero). This value is approximately two times the field-saturated hydrautic conductivity, $K_{f s}$, measured in the upper part of the soil profile with a Guelph permeameter (see Table 4.3 of Rockhold, Fayer, and Gee 1988). The field-measured water contents and hydraulic conductivities are not saturated values. For purposes of curve-fitting, however, $\theta_{S}$ and $K_{S}$ are simply notational distinctions representing the highest values of water content and hydraulic conductivity, respectively, that were obtained during the experiments. The Mualem (1976) conductivity model, as described by Rockhold, Fayer, and Gee (1988), was used with $K_{S}=2 E-3 \mathrm{~cm} / \mathrm{s}$ and the closed-form solution of the van Genuchten water retention function (van Genuchten 1978) to predict unsaturated hydraulic conductivities for both soil layers. Figure 5.5 shows the resulting hydraulic conductivity curves. 


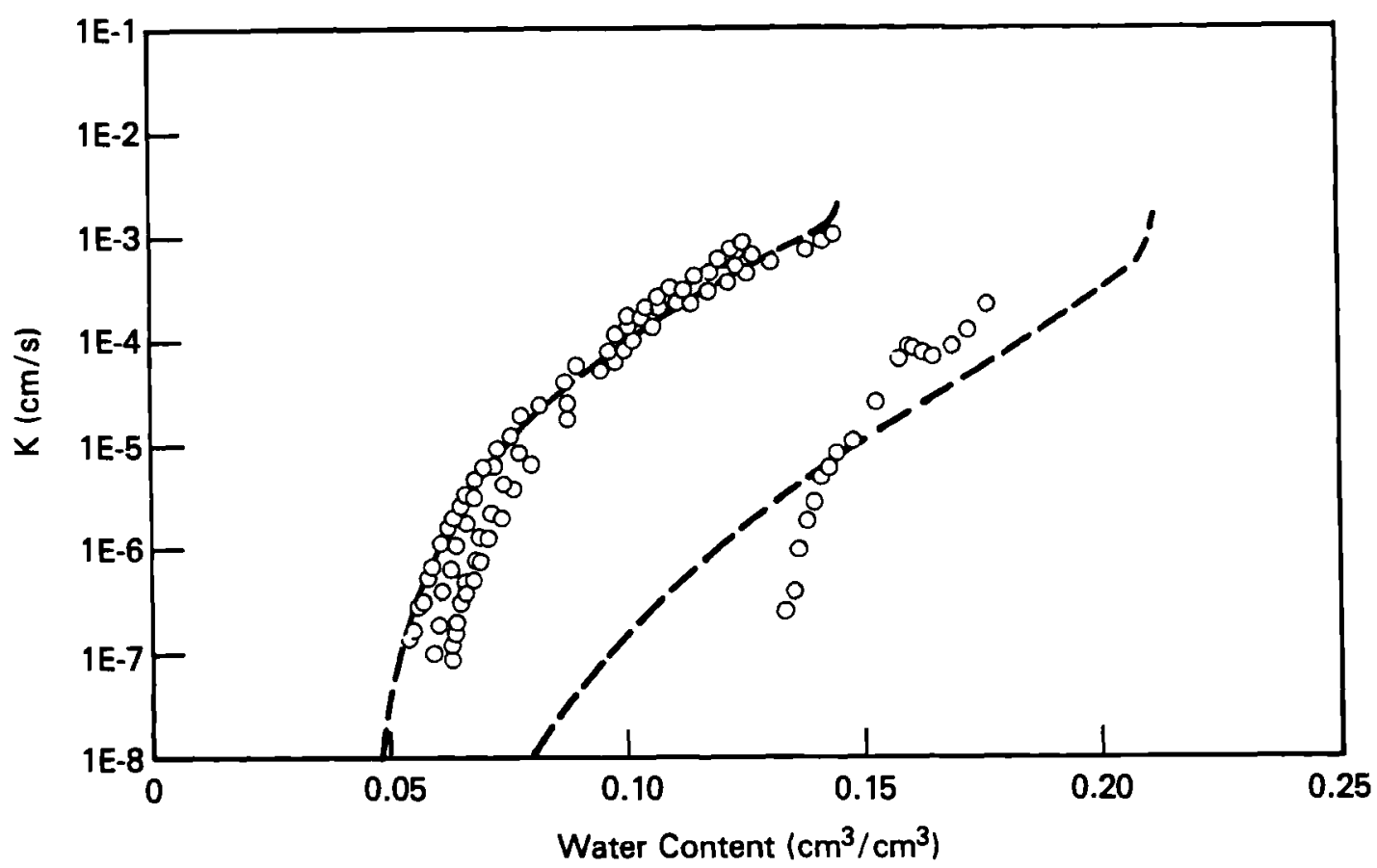

FIGURE 5.5. Calculated Hydraulic Conductivities for Second Experiment (restricted lateral flow) at the Grass Site. (Curve and data on right represent the $30-\mathrm{cm}$ depth. Curve and data on left represent 60 - to $180-\mathrm{cm}$ depths.)

The curve representing conductivities predicted for the lower soil layer in Figure 5.5 closely matches the measured conductivities over the range of measured water contents. Predicted conductivities represented by the curve depicting the $30-\mathrm{cm}$ depth are up to five times lower than calculated conductivities at water contents greater than $0.15 \mathrm{~cm}^{3} / \mathrm{cm}^{3}$, and up to an order of magnitude higher than calculated conductivities at water contents less than $0.15 \mathrm{~cm}^{3} / \mathrm{cm}^{3}$.

The variations in hydraulic properties within the upper part of the soil profile may be attributed to hysteresis (i.e., nonunique water content versus matric head relationships) and/or textural gradation. Soils with relatively high sand contents, such as those found at the Grass Site, generally show distinctly different (higher) water contents when drained than when wetted to the same matric head values. Laboratory-measured water retention data are most generally related to "primary drying curves" while field-measured water retention data are related to so-called "scanning curves" (Hillel 1982). 
Analyses of laboratory data yielded two relatively distinct groups of water retention characteristics. Averaging these characteristics yielded two sets of data representing the $0-$ to $40-\mathrm{cm} 1$ ayer and the $40-$ to $95-\mathrm{cm}$ layer at the site (see Table 5.2). Assuming these data are good representations of primary drying characteristics, the van Genuchten (1978) model was fit to the data to determine the primary drying curve for each layer. The resulting data and fitted water retention curves are shown in Figure 5.6.

The first few water retention data points measured after time zero from each depth in the unsteady drainage-flux experiment appear to fall on main wetting curves. As the soil profile drains, these data appear to break off of the wetting curves onto intermediate scanning curves. By assuming that main wetting curves have the same basic shape as main drying curves, and that these curves form a closed loop, a representation of the primary wetting characteristics for each layer was determined. The $\alpha$ parameter determined from fitting the laboratory water retention characteristics with the van Genuchten (1978) model was scaled according to $\alpha h=\alpha^{\prime} h^{\prime}$. The term $\alpha$ represents the fitted value for the laboratory data, and $h$ is the value of matric head on the fitted drying curve corresponding to $h^{\prime}$, which is measured at the same water content but presumably is on the main wetting curve.

TABLE 5.2. Laboratory-Measured Water Retention Characteristics for the Grass Site

Water Content, $\mathrm{cm}^{3} / \mathrm{cm}^{3}$, at Matric Head, $-\mathrm{cm}$

\begin{tabular}{|c|c|c|c|c|c|c|c|c|c|}
\hline epth, $\mathrm{cm}$ & 0 & 2 & 5 & 10 & 20 & 50 & 100 & 1000 & 15300 \\
\hline $\begin{array}{r}0-15 \\
15-30 \\
30-40 \\
\text { Mean }\end{array}$ & $\begin{array}{l}0.326 \\
0.273 \\
0.291 \\
0.297\end{array}$ & $\begin{array}{l}0.324 \\
0.273 \\
0.291 \\
0.296\end{array}$ & $\begin{array}{l}0.318 \\
0.273 \\
0.291 \\
0.294\end{array}$ & $\begin{array}{l}0.313 \\
0.265 \\
\frac{0.290}{0.294}\end{array}$ & $\begin{array}{l}0.296 \\
0.255 \\
0.194 \\
0.248\end{array}$ & $\begin{array}{l}0.258 \\
0.222 \\
0.161 \\
0.214\end{array}$ & $\begin{array}{l}0.169 \\
0.163 \\
0.155 \\
0.162\end{array}$ & $\begin{array}{l}0.094 \\
0.100 \\
0.098 \\
0.097\end{array}$ & $\begin{array}{l}0.068 \\
0.078 \\
0.070 \\
0.072\end{array}$ \\
\hline $\begin{array}{r}40-50 \\
50-60 \\
60-80 \\
80-90 \\
\frac{95}{\text { Mean }}\end{array}$ & $\begin{array}{l}0.388 \\
0.335 \\
0.364 \\
0.407 \\
0.422 \\
0.383\end{array}$ & $\begin{array}{l}0.386 \\
0.333 \\
0.364 \\
0.407 \\
\frac{0.422}{0.382}\end{array}$ & $\begin{array}{l}0.380 \\
0.327 \\
0.356 \\
0.399 \\
0.418 \\
0.376\end{array}$ & $\begin{array}{l}0.352 \\
0.239 \\
0.328 \\
0.335 \\
0.378 \\
0.326\end{array}$ & $\begin{array}{l}0.134 \\
0.092 \\
0.086 \\
0.096 \\
0.096 \\
0.101\end{array}$ & $\begin{array}{l}0.101 \\
0.077 \\
0.058 \\
0.066 \\
0.066 \\
0.074\end{array}$ & $\begin{array}{l}0.074 \\
0.060 \\
0.054 \\
0.040 \\
0.046 \\
0.055\end{array}$ & $\begin{array}{l}0.060 \\
0.043 \\
0.042 \\
0.040 \\
0.040 \\
0.045\end{array}$ & $\begin{array}{l}0.049 \\
0.039 \\
0.036 \\
0.033 \\
0.035 \\
0.038\end{array}$ \\
\hline
\end{tabular}




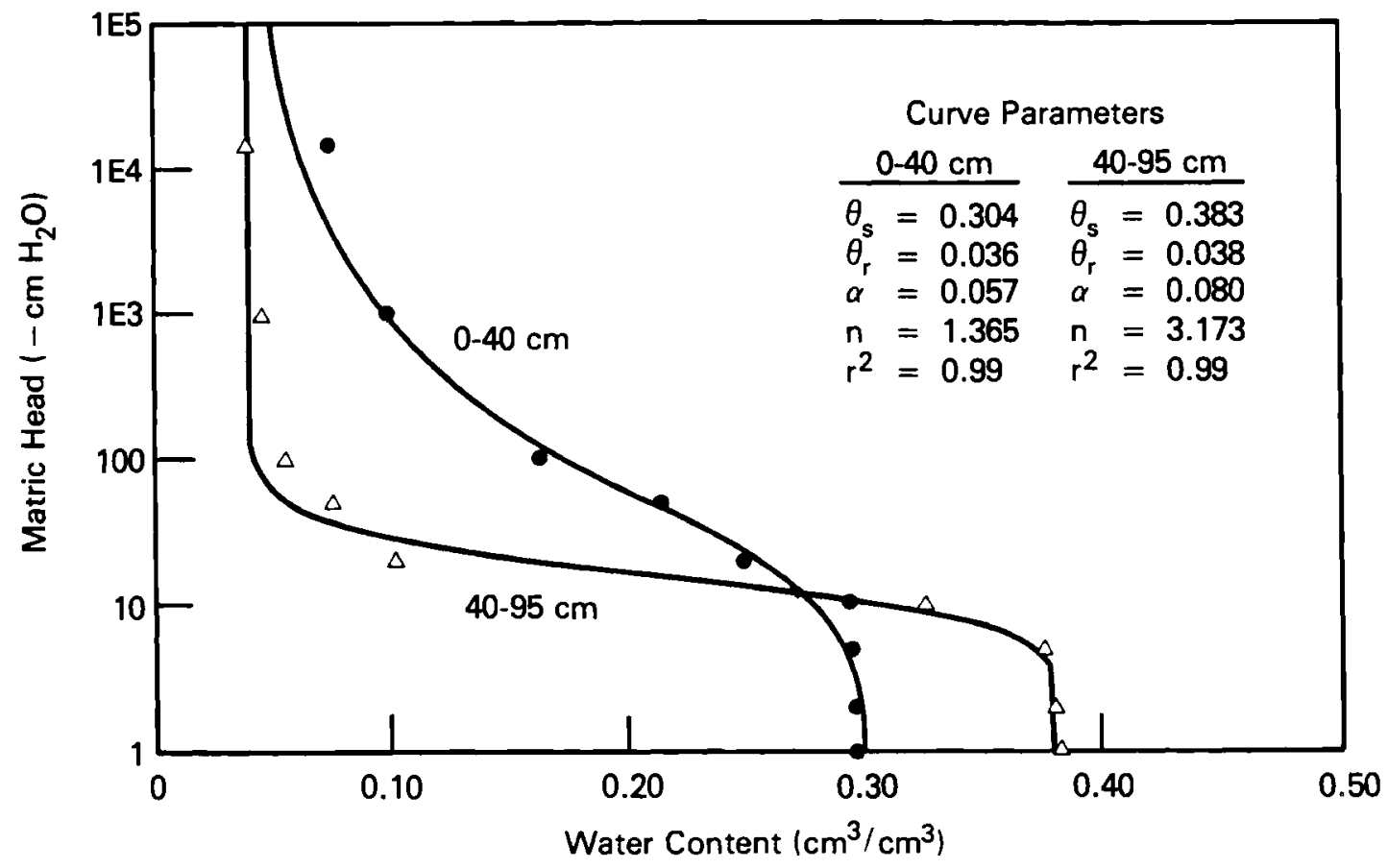

FIGURE 5.6. Water Retention Characteristics Measured in the Laboratory for Grass Site Soil

The $\alpha$ parameters determined by fitting the laboratory data were scaled as described, and the resulting wetting and drying curves are shown in Figures 5.7 and 5.8 with field data from the second unsteady drainage-flux experiment. These figures portray the upper and lower parts of the soil profile, respectively. The drying curves represent fits to average, laboratorymeasured water retention data. The hypothetical wetting curves may or may not accurately represent the actual wetting characteristics. Given the available data, however, these curves appear to be reasonable and to bracket the potential hysteretic behavior of the layers in this soil profile.

In conclusion, lateral flow was significant in the first unsteady, drainage-flux experiment at the Grass Site; this is evidenced by total profile water storage changes that were approximately $24 \%$ greater in the first experiment than in the second experiment, and calculated hydraulic conductivities for the first experiment, which were up to one order of magnitude greater than those calculated for the second experiment. 


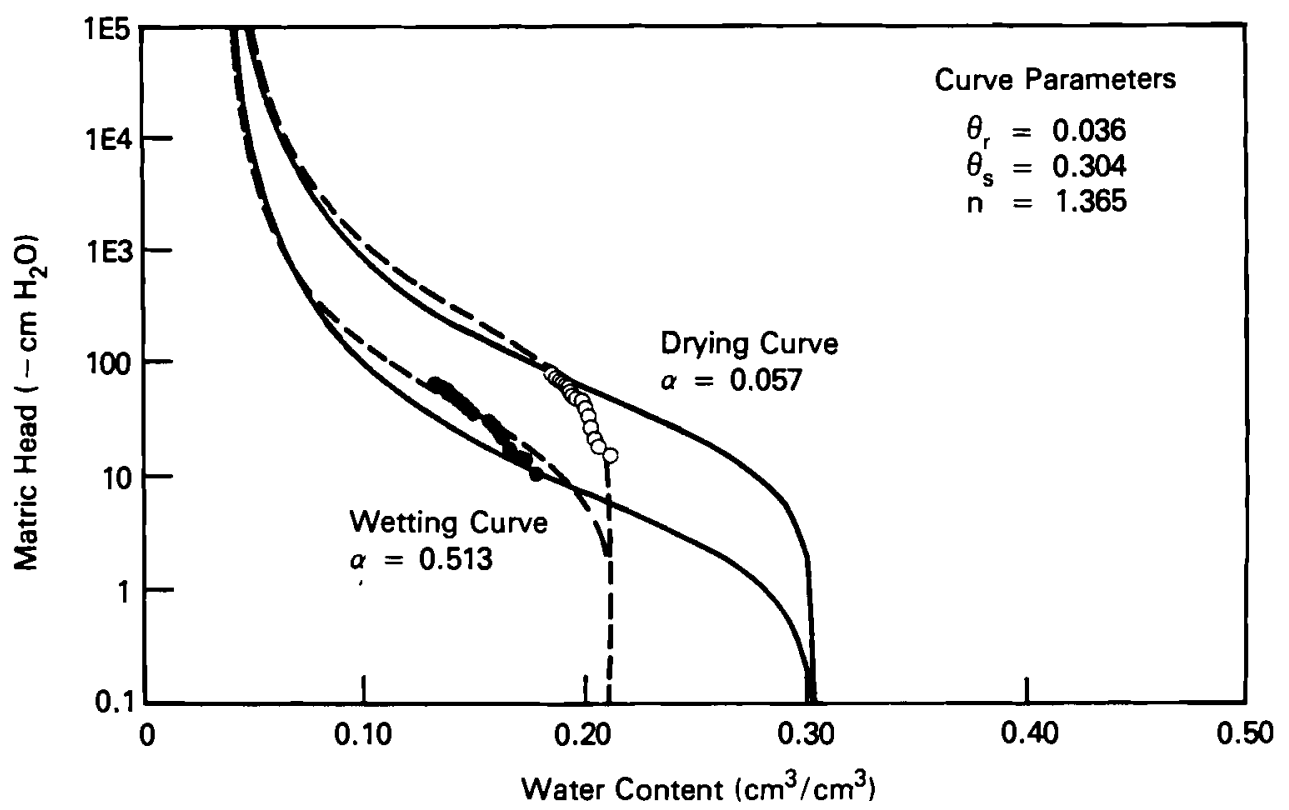

FIGURE 5.7. Field-Measured Water Retention Characteristics from the 30- and 45-cm Depths (upper soil profile) in the Second Experiment at the Grass Site. (Solid lines represent main drying and wetting curves. Dashed lines represent scanning curves.)

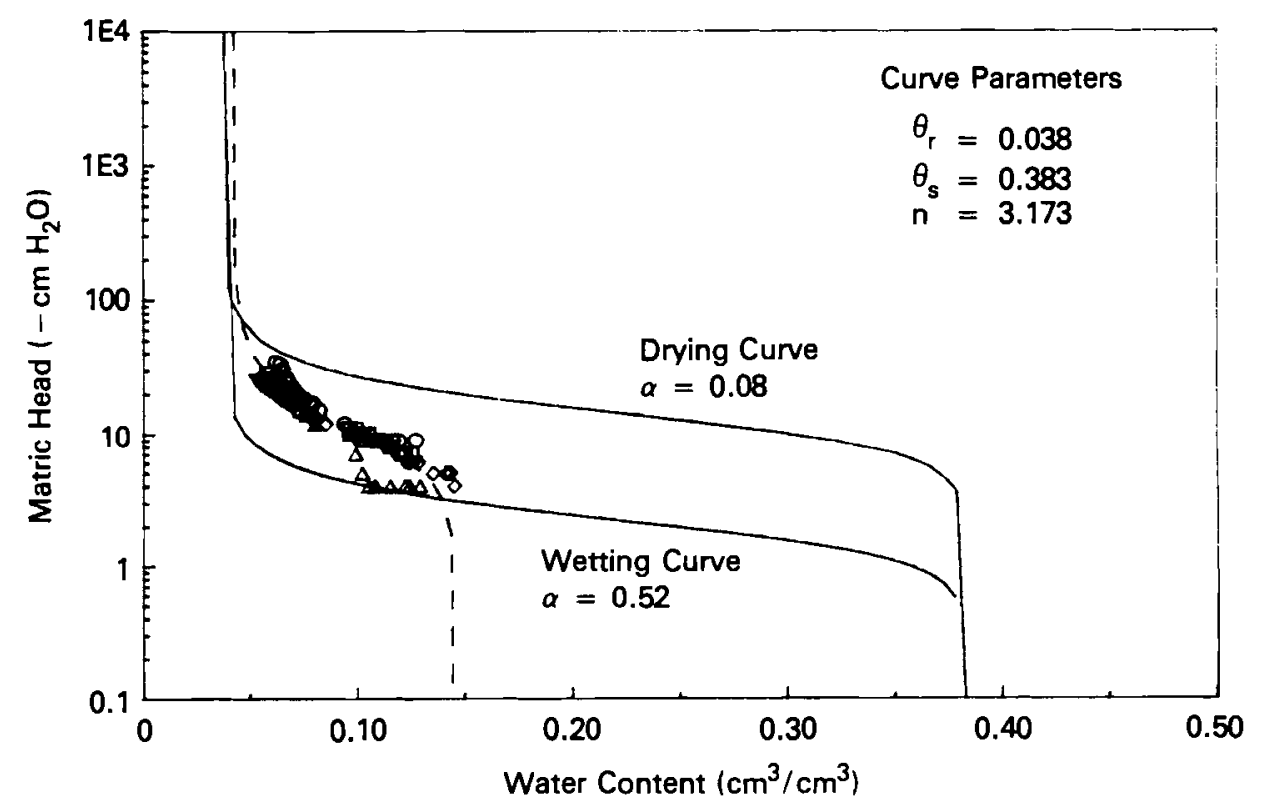

FIGURE 5.8. Field-Measured Water Retention Characteristics from the 60- to $180-\mathrm{cm}$ Depths (lower soil profile) in the Second Experiment at the Grass Site. (Solid lines represent main wetting and drying curves. Dashed line represents scanning curve.) 
The water retention data from these experiments also appear to exhibit hysteretic behavior. Assuming the field data to be hysteretic, water retention curves were fit to laboratory-measured water retention data to determine the main drying curves for the two soil layers. The fitted drying curve parameters were then scaled to generate hypothetical wetting curves. These wetting and drying curves approximate the potential hysteretic behavior of the field-measured water retention characteristics from the second experiment. Using such an approach to account for hysteresis effects helps to reconcile the differences between laboratory-and field-measured hydraulic properties. This evidence that hysteresis effects are significant suggests that hysteresis models should be incorporated into existing water balance computer codes such as UNSAT-H (Fayer, Gee, and Jones 1986). Until then, the laboratory drying curve parameters 1 isted in Figures 5.7 and 5.8 should be used for model simulations of the Grass Site, with $\mathrm{Ks}=2.0 \mathrm{E}-3 \mathrm{~cm} / \mathrm{s}$.

\subsection{UNSATURATED HYDRAULIC CONDUCTIVITY FOR THE MCGEE RANCH}

The first unsteady drainage-flux method experiment at the McGee Ranch was also repeated because of uncertainties as to whether or not the 2-m by $2-m$ plot size was sufficient to create a buffer zone that minimized lateral flow out of the plot profile. In the second experiment at this site, the plot area was expanded to approximately $4 \mathrm{~m}$ by $4 \mathrm{~m}$. A trench was not dug around the plot profile and sealed with plastic as in the second experiment at the Grass Site, because no distinct layering of the soil profile was evident at the McGee Ranch.

Measured water retention characteristics and calculated hydraulic conductivities from this second experiment were very similar to those of the first experiment. If lateral flow out of the plot was significant in either experiment, it was not apparent because of the relative uniformity of the soil profile. Therefore, the results of the first unsteady drainage-flux experiment conducted at the McGee Ranch are judged to be valid (Rockhold, Fayer, and Gee 1988). Data from the second experiment at the McGee Ranch are listed in Appendix $E$ of this report. 


\subsection{WATER RETENTION CHARACTERISTIC PREDICTIONS}

The Arya-Paris (1981) model is a capillary pore model that translates particle-size distributions into pore-size distributions. Cumulative pore volumes, corresponding to increasing pore radii, are divided by the sample bulk volume to determine the volumetric water contents. The pore radi $i$ are then converted to equivalent matric head values by using the equation of capillarity.

To compute pore volumes and radii, the particle-size distribution is subdivided. The solid mass of each subdivision is assumed to form a matrix with a bulk density equal to that of an undisturbed field sample. An equivalent pore volume for a unit of sample mass is then computed from

$$
V v_{i}=\left(w_{j} / \rho_{p}\right) e ; i=1,2, \ldots, n
$$

and the corresponding pore radius from

$$
r i_{i}=R_{i}\left[4 e n_{i}(1-\underline{a}) / 6\right]^{1 / 2}
$$

where $V v_{j}=$ pore volume

$$
\begin{aligned}
W_{i} & =\text { solid mass } \\
\rho_{\mathrm{p}} & =\text { particle density } \\
\mathrm{e} & =\text { void ratio } \\
r_{i} & =\text { mean pore radius } \\
\mathrm{R}_{j} & =\text { particle radius } \\
\mathrm{n}_{\mathrm{i}} & =\text { number of particles } \\
\underline{\mathrm{a}} & =\text { constant (pore geometry factor) }
\end{aligned}
$$

The Arya-Paris model approximates a pore length, which corresponds to a given particle-size range, as the number of particles that lie along the pore path times the length contributed by each particle. In a cubic close-packed assemblage of uniform-size spheres, the total pore length is estimated to be equal to $n_{j} 2 R_{j}$. Because actual soil particles are nonspherical, the model assumes each particle will contribute a length greater than the diameter of an equivalent sphere. The number of particles required to track a pore path 
is then assumed to equal $n_{j}{ }^{a}$, where $\underline{a}$ is greater than 1 . Thus, the $\underline{a}$ parameter essentially adjusts the pore radi $i$ formulation to account for the nonsphericity of particles and pore tortuosity.

The concept of fractals provides a means of quantifying a variety of scale-invariant processes in nature (Mandelbrot 1982). A power function relationship between number and size is by definition a fractal. Turcotte (1986) has shown that the cumulative particle-size distribution of natural soil materials can be of a fractal nature of the form

$$
N=C R^{-D}
$$

where $N$ is the number of particles larger in radius than $R, C$ is a constant, and $D$ is the fractal dimension. Mandelbrot, Passoja, and Paullay (1984) suggest that the fractal dimension of a transect through a fractal volume can be taken as two less than the dimension of the volume.

Scott Tyler of the Desert Research Institute, Reno, Nevada, suggested application of the concepts of fractal mathematics to independently estimate the a parameter in the Arya and Paris (1981) water retention model. Work by Tyler(a) suggests that the a parameter may be equal to the fractal dimension of a pore trace, representing the tortuosity of the pore trace. Thus, given a particle-size distribution, the fractal dimension of a tortuous pore trace (the a parameter) can be determined by subtracting two from the absolute value of the slope of a log-log plot of particle radii versus cumulative number of particles.

To test this technique for independently determining the a parameter in the Arya and Paris (1981) model, particle-size distribution data were first digitized by PNL from curves representing soils $C$ and $F$ in Figure 1 of Arya and Paris (1981). The a parameters were then determined from these particlesize distributions by plotting mean particle radii (mm) versus cumulative number of particles greater than the radii.

(a) Personal Communication with S. W. Tyler, Desert Research Institute, University of Nevada, Reno, Nevada, 1987. 
The a parameter determined from this fractal analysis for soil $\mathrm{C}$ was 1.227. The best-fit value of the parameter determined by Arya and Paris for this soil was 1.362. Arya and Paris (1981) computed this value by minimizing the sums of the absolute value of the logs of measured matric heads minus the logs of predicted matric heads.

Figure 5.9 shows the cumulative number of particles plotted versus mean particle radius from digitized data representing Arya and Paris soil $F$. The a parameter determined by this analysis was 0.948 . Four of the digitized data points were then selectively removed and a first-order regression of the remaining data yielded an a parameter of 1.056. This example illustrates the sensitivity of this fractal determination of the a parameter to the number and spacing of particle-size-distribution data points. The best-fit value of the a parameter determined by Arya and Paris (1981) for soil $\mathrm{F}$ was 1.389 .

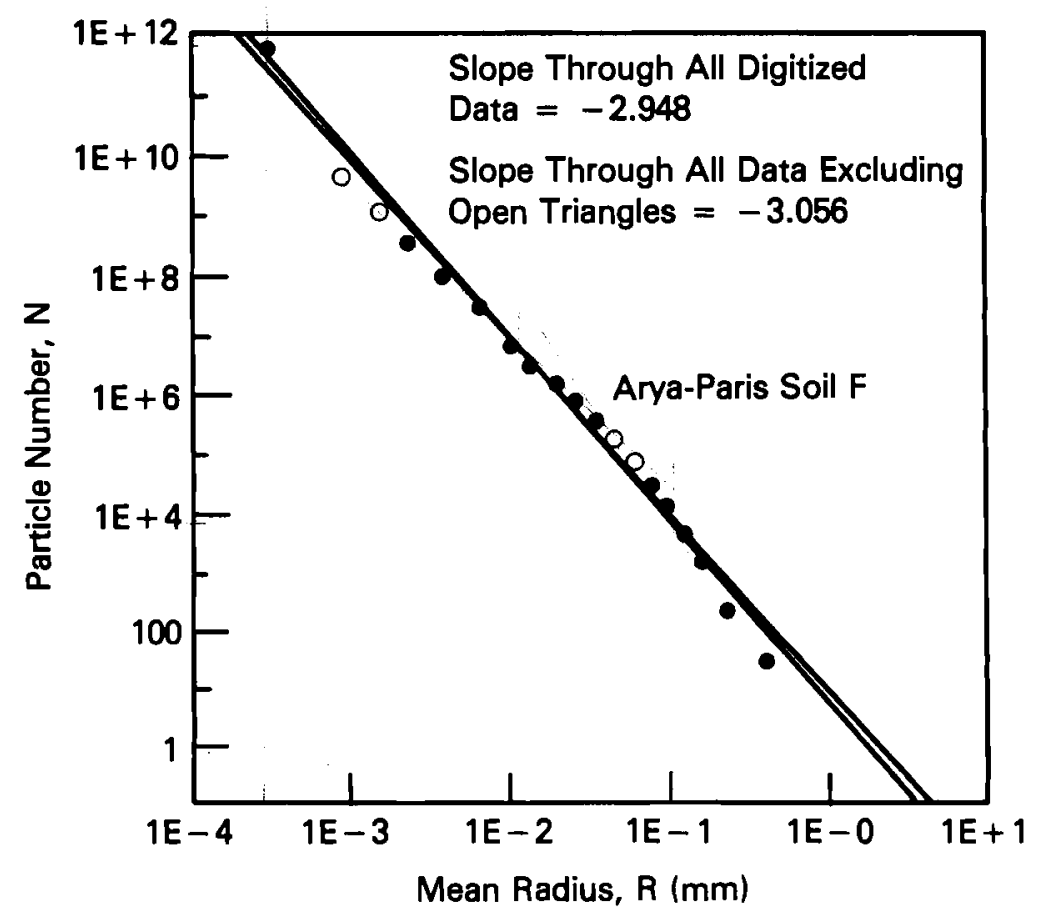

FIGURE 5.9. Computed Slopes for Particle Number Versus Mean Radius for Soil F of Arya and Paris (1981) 
Sixteen soil samples were also collected from the FLTF and analyzed by this fractal approach to determine the a parameter. The samples represent a composite of $A$ to $C$ soil horizons that were excavated from the borrow pit at the McGee Ranch. This pit is located adjacent to the unsteady, drainage-flux experiment plot at the site. Particle-size distributions, particle densities, and water retention characteristics were determined for these samples using standard analysis methods (K1ute 1986).

All of the samples are classified as silt loams with the exception of two, which are classified as loams. The sand, silt, and clay percentages of the samples ranged from $32-44 \%, 42-59 \%$, and $7-14 \%$, respectively. Results of the particle-size analyses for these soils are listed in Table 5.3. The average particle density of the samples was $2.72( \pm 0.04) \mathrm{g} / \mathrm{cm}^{3}$.

Water retention characteristics were predicted, using the Arya and Paris (1981) model, from the particle-size distributions of each of the 16 samples, with the fractal analysis to determine the a parameters. A bulk density of $1.37 \mathrm{~g} / \mathrm{cm}^{3}$ and a particle density of $2.72 \mathrm{~g} / \mathrm{cm}^{3}$ were used for al1 model predictions. The best-fit values of the a parameter, visually determined for the $16 \mathrm{FLTF}$ samples, ranged from 1.10 to 1.25 . The a parameters determined for three of the samples by the fractal analyses were outside the visually determined best-fit range (see Table 5.4). These samples were D05-03 $(\underline{a}=1.081), D 13-08(\underline{a}=1.265)$, and D14-04 ( $\underline{a}=1.328)$. Using these three $\underline{a}$ parameters in the Arya and Paris model resulted in predicted water retention characteristics that were not in as close agreement (visually) with the measured data as can be obtained with different values of $\underline{a}$. Therefore, the

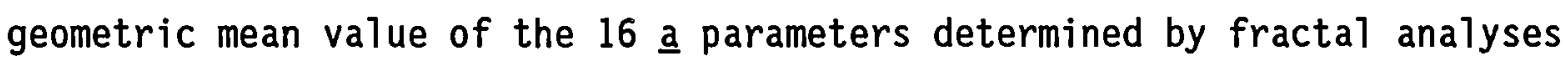
was used for predicting water retention characteristics for al1 16 samples using the Arya and Paris model. This mean value is 1.201 , with a geometric standard deviation of 0.002 . The geometric mean, rather than the arithmetic mean, was used because particle-size distribution data generally show lognormal distributions. The arithmetic mean value of a , however, is 1.203 , with a standard deviation of 0.003 . The results of these fractal analyses are listed in Table 5.4. 
TABLE 5.3. Results of Soil Particle-Size Analysis for the Field Lysimeter Test Facility

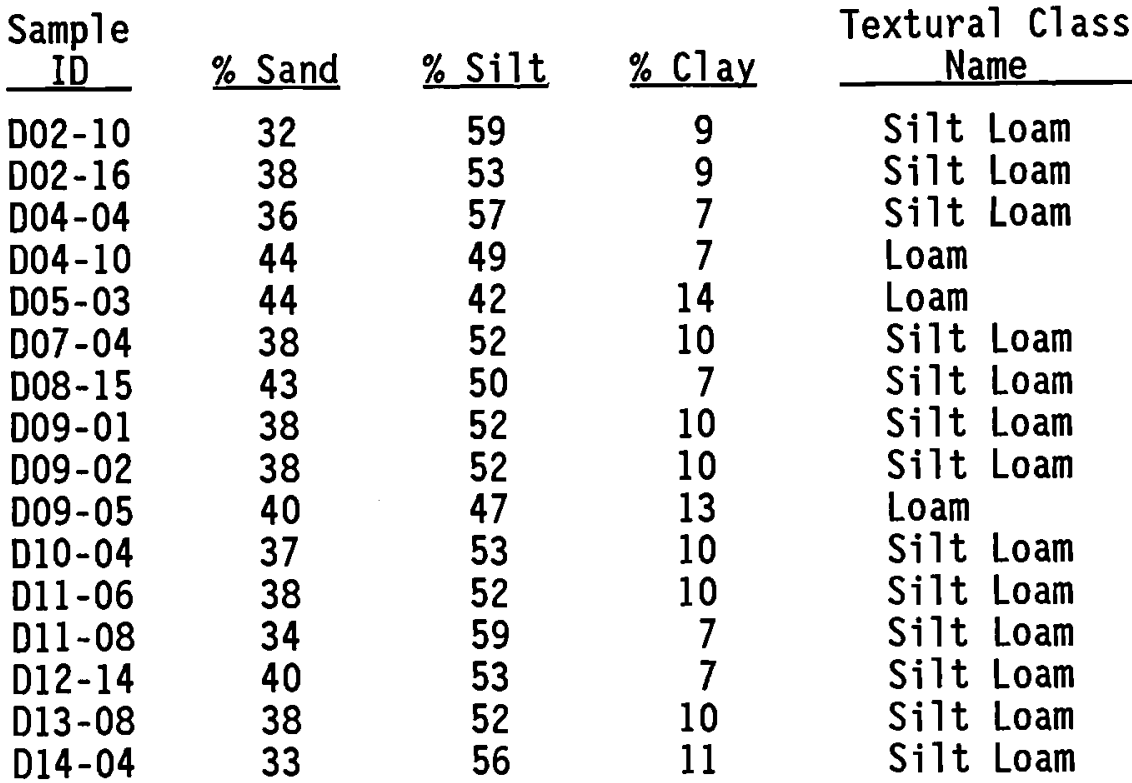

TABLE 5.4. Fractal Analysis Results of Field Lysimeter Test Facility Soil Particle-Size Distribution Data. Least-squares regressions of mean radius $(\mathrm{mm})$ versus particle number.

$\begin{array}{cc}\begin{array}{c}\text { Sample } \\ \text { ID }\end{array} & \\ \text { D1ope } \\ \text { D02-10 } & -3.244 \\ \text { D02-16 } & -3.201 \\ \text { D04-04 } & -3.220 \\ \text { D04-10 } & -3.166 \\ \text { D05-03 } & -3.081 \\ \text { D07-04 } & -3.186 \\ \text { D08-15 } & -3.151 \\ \text { D09-01 } & -3.188 \\ \text { D09-02 } & -3.190 \\ \text { D09-05 } & -3.175 \\ \text { D10-04 } & -3.241 \\ \text { D11-06 } & -3.195 \\ \text { D11-08 } & -3.238 \\ \text { D12-14 } & -3.171 \\ \text { D13-08 } & -3.265 \\ \text { D14-04 } & -3.328\end{array}$

\begin{tabular}{c} 
Intercept \\
\hline 0.316 \\
0.394 \\
0.360 \\
0.453 \\
0.644 \\
0.441 \\
0.490 \\
0.432 \\
0.433 \\
0.446 \\
0.298 \\
0.409 \\
0.319 \\
0.433 \\
0.265 \\
0.139
\end{tabular}

\begin{tabular}{c}
$r^{2}$ \\
\hline 0.980 \\
0.980 \\
0.980 \\
0.976 \\
0.988 \\
0.984 \\
0.978 \\
0.982 \\
0.982 \\
0.982 \\
0.976 \\
0.980 \\
0.980 \\
0.976 \\
0.976 \\
0.980
\end{tabular}

Fractal Dimension,

\begin{tabular}{l}
\multicolumn{1}{c}{$\underline{\mathrm{a}}$} \\
\hline 1.244 \\
1.201 \\
1.220 \\
1.166 \\
$1.081(\mathrm{a})$ \\
1.186 \\
1.151 \\
1.188 \\
1.190 \\
1.175 \\
1.241 \\
1.195 \\
1.238 \\
1.171 \\
$1.265(\mathrm{a})$ \\
$1.328(\mathrm{a})$
\end{tabular}

Geometric Mean $\underline{a}=1.201$

Standard Deviation $=0.002$

(a) Values are outside the visually determined best-fit range of $\underline{a}$. 
Measured water retention characteristics from four of the 16 FLTF soil samples are plotted with predicted values in Figures 5.10 and 5.11. Model predictions match the measured data for all 16 samples within a factor of two of matric head values between water contents of $0.40 \mathrm{~cm}^{3} / \mathrm{cm}^{3}$ and $0.10 \mathrm{~cm}^{3} / \mathrm{cm}^{3}$. At water contents between $0.40 \mathrm{~cm}^{3} / \mathrm{cm}^{3}$ and $0.496 \mathrm{~cm}^{3} / \mathrm{cm}^{3}$, the predicted values are generally greater than the measured data by as much as a factor of five. The value of $0.496 \mathrm{~cm}^{3} / \mathrm{cm}^{3}$ is the total porosity calculated for the laboratory samples, which were all packed to a bulk density of $1.37 \mathrm{~g} / \mathrm{cm}^{3}$.

None of the 1aboratory samples were thoroughly saturated (i.e., they al1 had water contents that were less than the calculated total porosity). Therefore, it is possible that the predicted water retention characteristics do not match the measured data more closely at higher water contents because the measured data actually represent points on hysteresis loops before reaching the primary drying curve at a water content of about $0.40 \mathrm{~cm}^{3} / \mathrm{cm}^{3}$. At water contents below about $0.10 \mathrm{~cm}^{3} / \mathrm{cm}^{3}$, water retention characteristics predicted for this soil by a capillary pore model should not be expected to match measured data as well as at higher water contents, because under these drier soil moisture conditions, water is held primarily in surface films and may not behave in accordance with capillary laws. Overall, the predicted water retention characteristics appear to be good representations of points on main drying curves at water contents between $0.496 \mathrm{~cm}^{3} / \mathrm{cm}^{3}$ and $0.100 \mathrm{~cm}^{3} / \mathrm{cm}^{3}$.

Third-order polynomial, least-squares regressions were performed on the predicted water retention characteristics for each sample between matric heads of $-50 \mathrm{~cm}$ to $-3800 \mathrm{~cm}$. The equations of the fitted curves (R-values of 0.99 to 1.00 ) were then used to calculate matric heads for each sample (at the 1aboratory-measured water contents) corresponding to matric heads of $-100 \mathrm{~cm},-150 \mathrm{~cm},-510 \mathrm{~cm},-1020 \mathrm{~cm}$, and $-4080 \mathrm{~cm}$. Predicted and measured matric heads at fixed-water contents are compared in Figure 5.12. A firstorder regression of predicted versus measured matric head values resulted in a slope of 0.87 , with $r^{2}$ equal to 0.956 . 

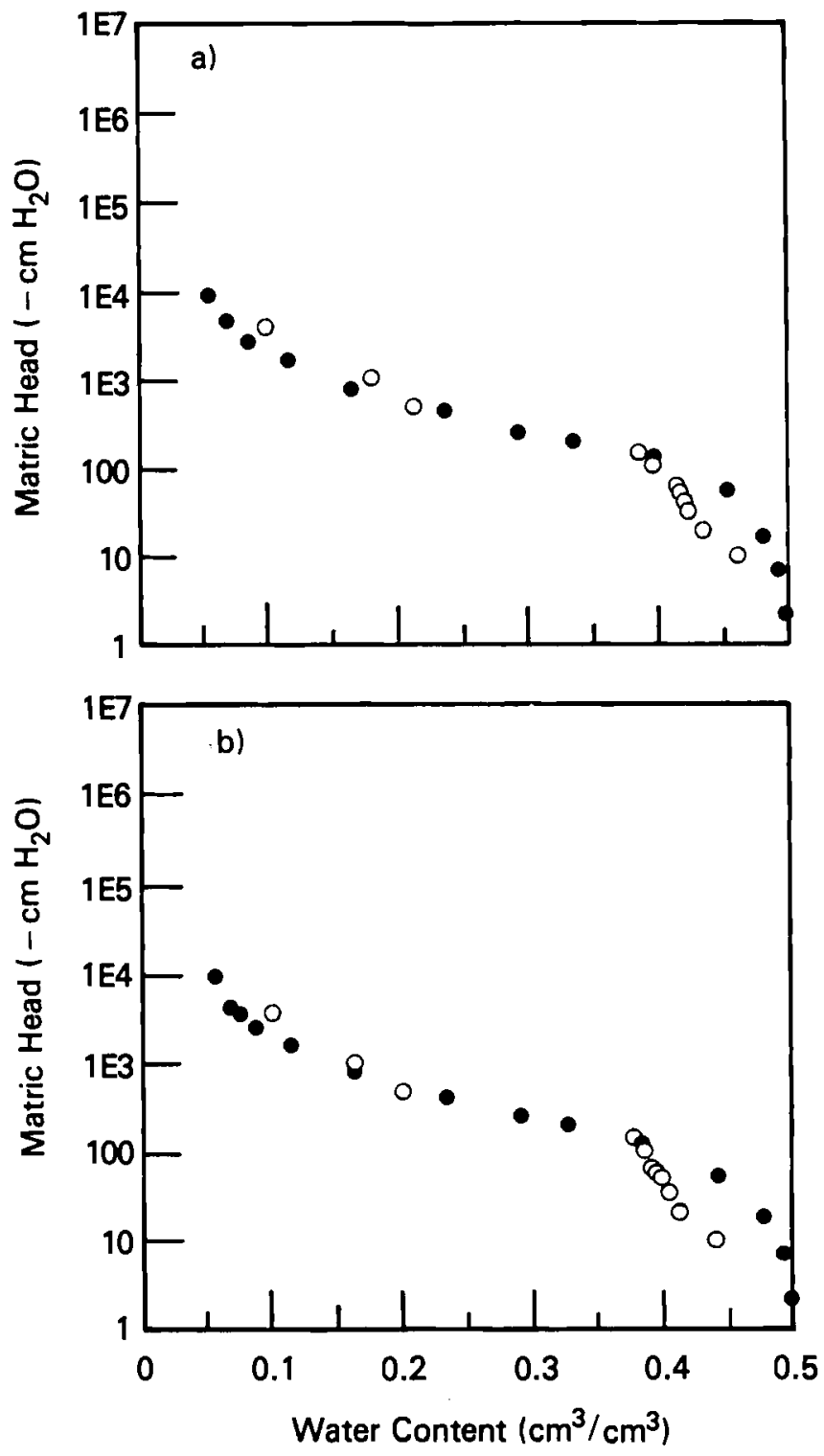

FIGURE 5.10. Soi1-Water Retention Characteristics for the McGee Ranch. a) Represents sample FLTF D10-04; b) represents sample FLTF D11-06. [Solid circles are predicted from the Arya and Paris (1981) model. Open circles are measured data.] 

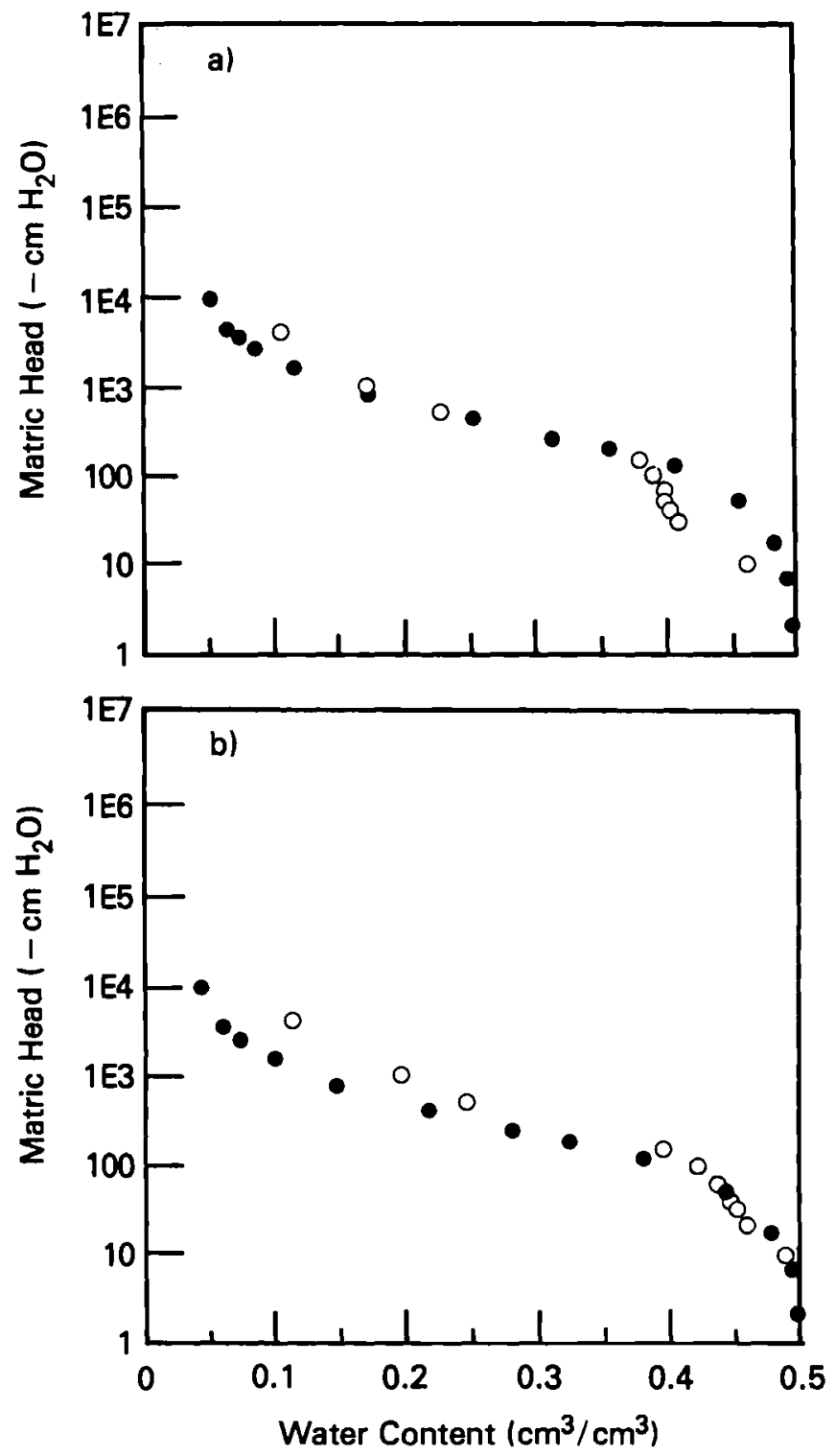

FIGURE 5.11. Soil-Water Retention Characteristics for the McGee Ranch. a) Represents sample FLTF DI1-08; b) represents sample FLTF D12-14. [Solid circles are predicted from the Arya and Paris (1981) Mode1. Open circles are measured data.]

Figure 5.12 shows that the measured and predicted values are in close agreement at matric heads of $-100 \mathrm{~cm}$ and $-510 \mathrm{~cm}$, and are reasonable at $-1000 \mathrm{~cm}$. The range in variation of the predicted matric head values is about the same as that for the five measured matric head values shown, suggesting that the variability in the predictions stems from differences in 


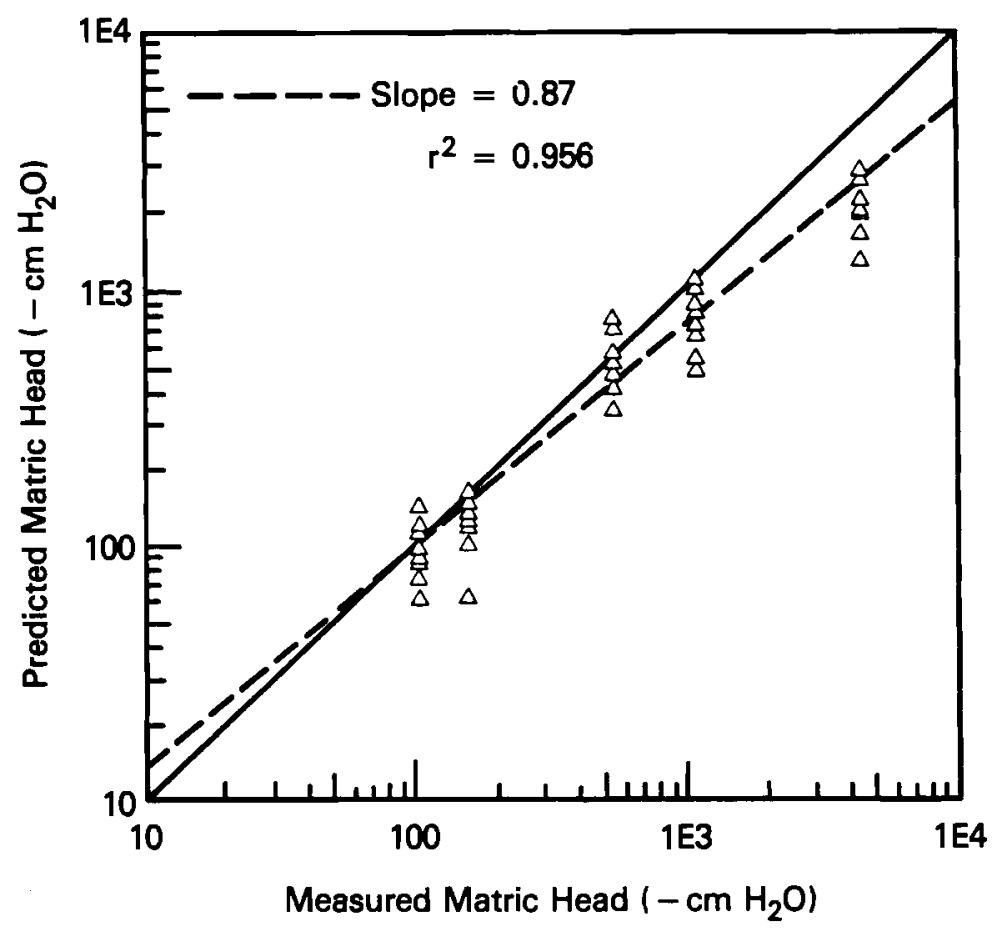

FIGURE 5.12. Predicted Versus Measured Matric Head Values for 16 McGee Ranch (FLTF) Soils for a Range of $-100 \mathrm{~cm}$ to $-5000 \mathrm{~cm}$ of Matric Head

the particle-size distributions of the samples. This variation may also be due in part to the use of the geometric mean a rather than individual a's for each sample.

Fractal analysis was also performed on particle-size distribution data from the upper and lower parts of the soil profile at the Grass Site. Figure 5.13 shows the regressions of particle number versus mean radius for these data. The a parameters determined from these analyses are 0.718 and 0.463 for the upper and lower parts of the soil profile, respectively.

According to Tyler(a) a small fractal dimension indicates a fairly straight flow path, while a fractal dimension greater than 1.5 yields tortuous pore channel representations which are unrealistic. Tyler also suggests that fractal dimensions of pore traces that are less than one do not

(a) Personal Communication with S. W. Tyler, Desert Research Institute, University of Nevada, Reno, Nevada, 1987. 


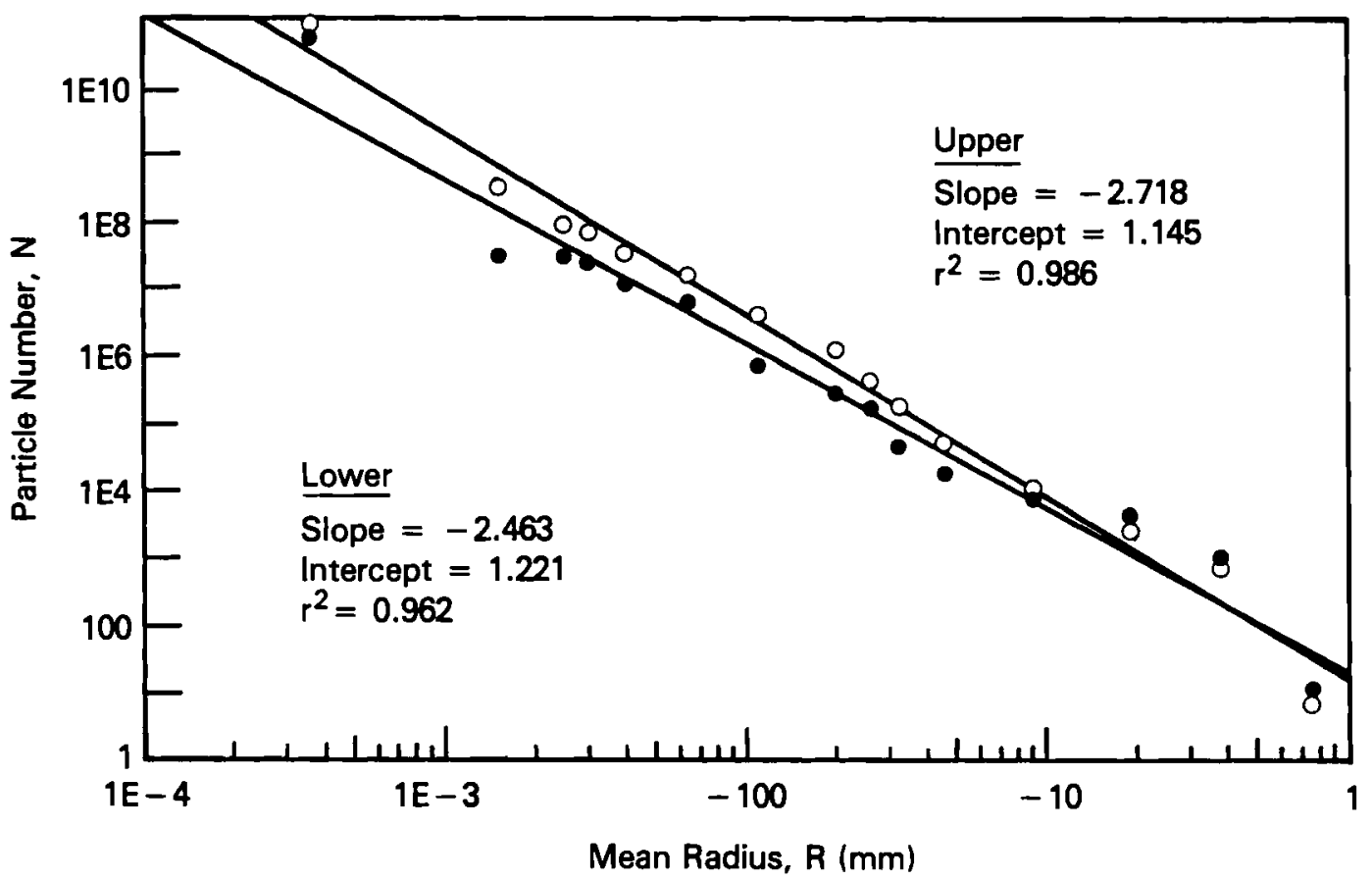

FIGURE 5.13. Particle Number Versus Mean Radius for Grass Site Soils. (Lower curve represents $60-\mathrm{cm}$ depth. Upper curve represents $20-\mathrm{cm}$ depth.)

show scale-invariant similarity, and that use of the fractal model is not appropriate in such cases. Therefore, the a parameters used in the Arya and Paris (1981) model for the Grass Site were determined by visual fit to the mean laboratory-measured water retention data. The laboratory data, rather than the field data, were used because the laboratory data appeared to be more representative of main drying characteristics.

Figure 5.14 shows the water retention curves fit to laboratory data and the water retention characteristics predicted by the Arya and Paris (1981) model for the Grass Site. Mean particle-size distribution data from the upper and lower parts of the soil profile at the Grass Site were used to generate these predicted characteristics. The best-fit values of a were visually determined from these data and are 1.5 and 1.3 for the upper and lower parts of the soil profile, respectively. 


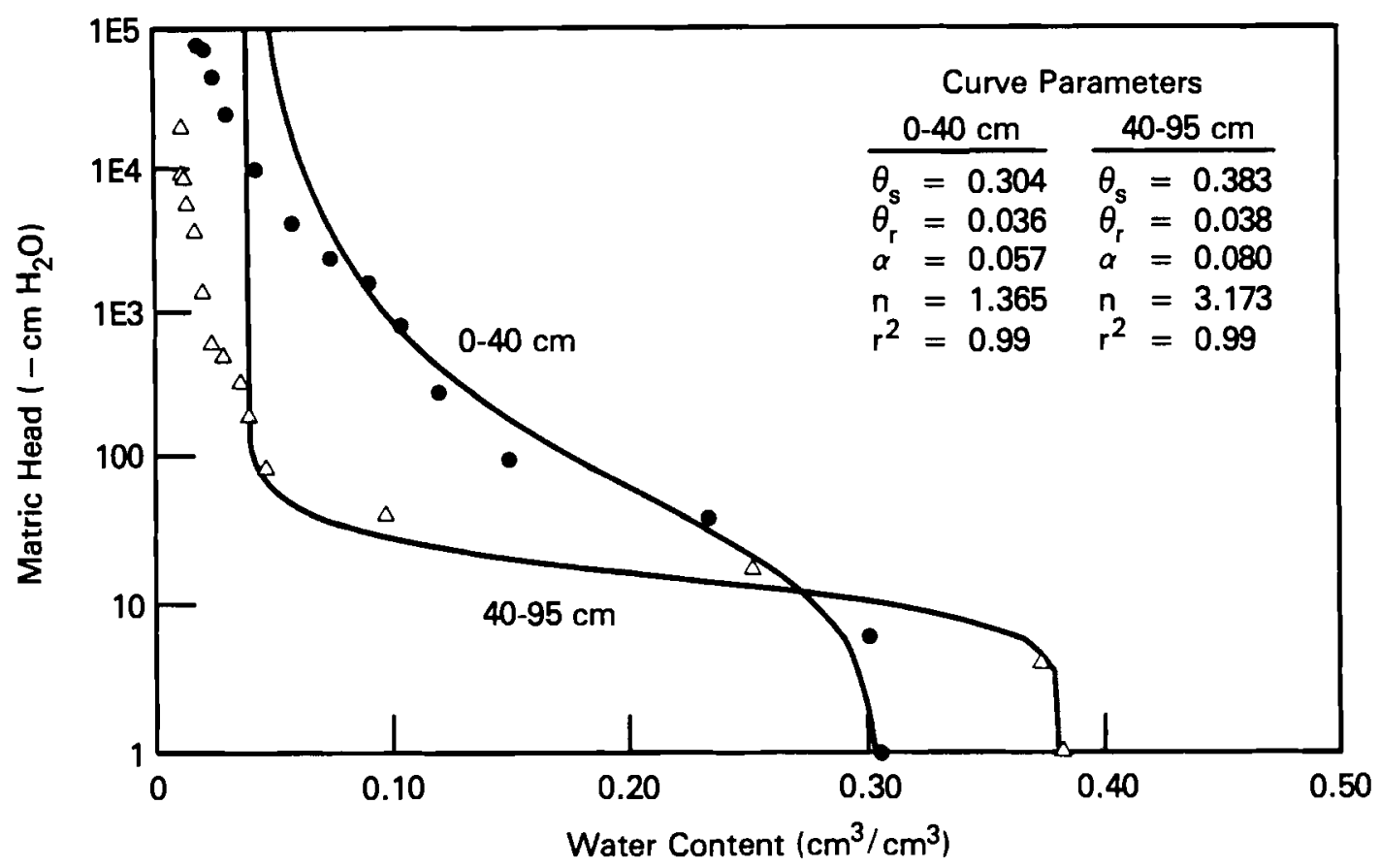

FIGURE 5.14. Water Retention Curves and Curve-Fitting Parameters for the Grass Site. (Solid lines represent laboratory data. Points represent characteristics predicted from the Arya and Paris model.)

Predicted water retention characteristics are in agreement with the curve representing the mean 1aboratory water retention characteristics for the upper part of the soil profile within a factor of two for water contents from $0.304 \mathrm{~cm}^{3} / \mathrm{cm}^{3}$ to about $0.080 \mathrm{~cm}^{3} / \mathrm{cm}^{3}$. At water contents from $0.080 \mathrm{~cm}^{3} / \mathrm{cm}^{3}$ to the residual water content of $0.036 \mathrm{~cm}^{3} / \mathrm{cm}^{3}$, the predicted characteristics underestimate matric head by up to an order of magnitude. Predicted water retention characteristics for the lower part of the soil profile match the mean laboratory-measured water retention characteristics within a factor of two from $0.383 \mathrm{~cm}^{3} / \mathrm{cm}^{3}$ to the residual water content of $0.038 \mathrm{~cm}^{3} / \mathrm{cm}^{3}$.

Fractal analysis was also used to estimate the a parameter for the BWTF soi1. The same composite particle-size distribution from samples $18 \mathrm{~A}$ and $18 \mathrm{~B}$ that was used previously in the study by Rockhold, Fayer, and Gee (1988), was used to estimate the a parameter by fractal analysis. Figure 5.15 shows the 


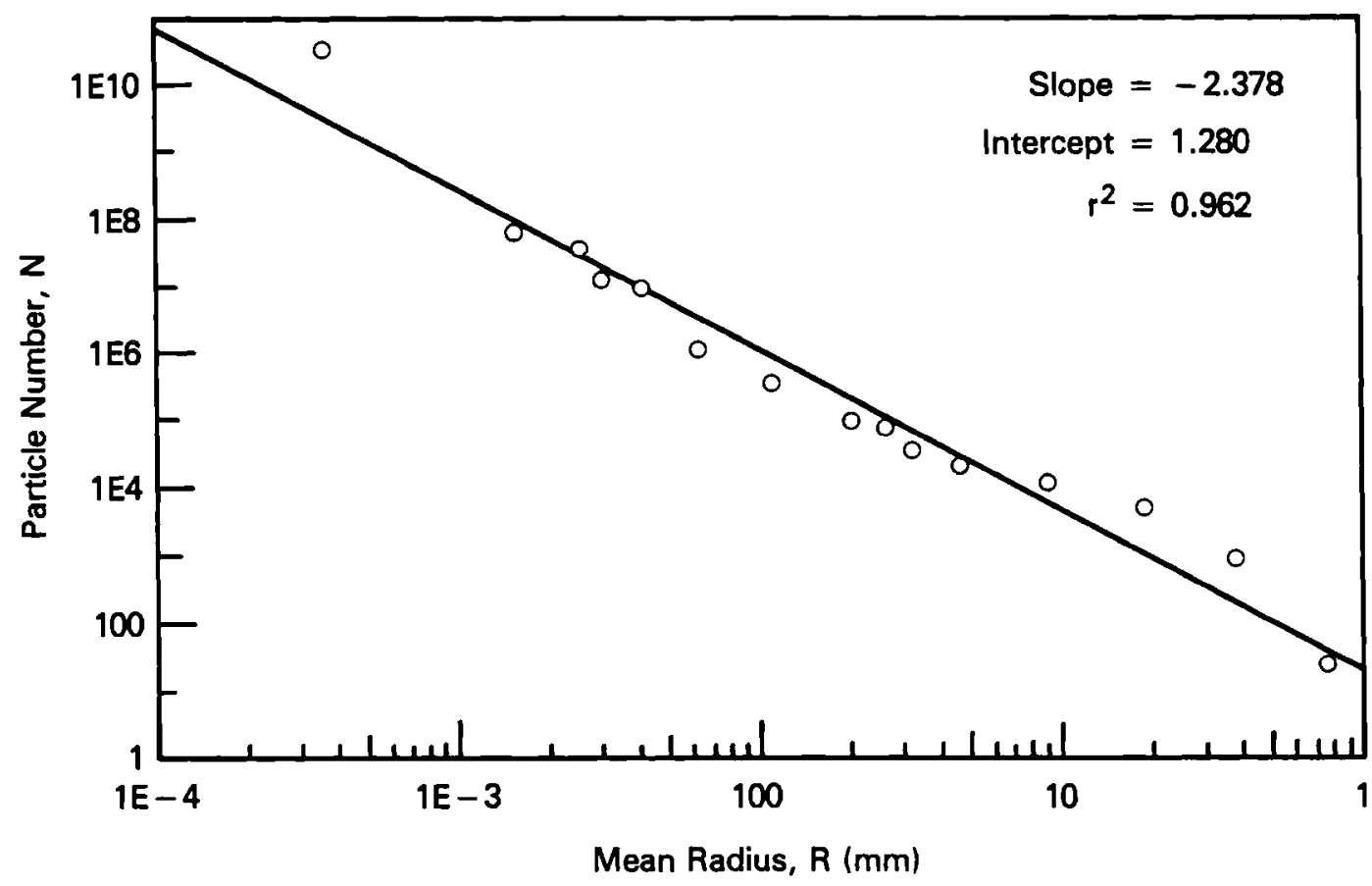

FIGURE 5.15. Particle Number Versus Mean Radius for Sandy Soil at the Buried Waste Test Facility

$\log -\log$ plot from these data of particle number versus mean radius. The $\underline{a}$ parameter determined from this analysis is 0.378 . This low value indicates that, like the Grass Site soil, the BWTF sand does not show scale-invariant similarity and, thus, the fractal model is not appropriate to use. The visually determined best-fit a for this soil, taken from previous work by Rockhold, Fayer, and Gee (1988), is 1.18.

In conclusion, the Arya and Paris (1981) model provides reasonable estimates of water retention characteristics for the range of matric heads (from 0 to $-1000 \mathrm{~cm}$ ) where capillary flow dominates for the soils from the Grass Site, McGee Ranch, and BWTF. Determination of the a parameter using fractal analysis was successful for the McGee Ranch silt loam soil, but was not successful for the sandy loam and sands from the Grass Site and BWTF. The a parameters generated from these analyses for the Grass Site and BWTF soils were less than one, indicating that these soil materials do not show 
scale-invariant similarities. In such cases(a), this particular fractal model is inappropriate.

Tyler(a) also noted that this fractal analysis yields estimates of $\underline{a}$ that are less than one for one of the sandy soils of his study. It is currently unclear whether this nonfractal behavior is generally typical for coarser-textured soils. The fractal determination of the a parameter is also highly sensitive to the number of and spacing of particle-size distribution data points. Therefore, it was necessary to determine the a parameters in the Arya and Paris (1981) model for soils from the Grass Site and BWTF by visually fitting predicted water retention characteristics to measured data. Variations of the fractal model used could potentially be developed for estimating the a parameter for these coarser-textured soils.

\subsection{HYDRAULIC PROPERTY SUMMARY}

The parameters in Table 5.5 summarize the hydraulic properties of the Grass Site and McGee Ranch soils.

Field-measured saturated hydraulic conductivities were in close agreement with laboratory-measured saturated hydraulic conductivities. Unsaturated hydraulic conductivities calculated from field data for two experiments varied by up to one order of magnitude, depending on initial and boundary conditions.

Field-measured water retention characteristics showed considerable differences from laboratory-measured data. These differences were attributed to hysteresis effects, which were effectively bracketed by scaling the main drying curves determined from laboratory data to generate hypothetical wetting curves.

Water retention characteristics predicted from particle-size and bulk density data using a capillary pore model matched laboratory-measured values within a factor of two of the matric head over the range of field-measured water contents. The fractal parameter estimation technique tested for (a) Personal Communication with S. W. Tyler, Desert Research Institute,
University of Nevada, Reno, Nevada, 1987. 
estimating a parameter in the capillary pore model was successful for only one of the three soils tested.

TABLE 5.5 Curve-Fitting Parameters for the van Genuchten (1978) Water Retention and Mualem (1976) Predictive Conductivity Models

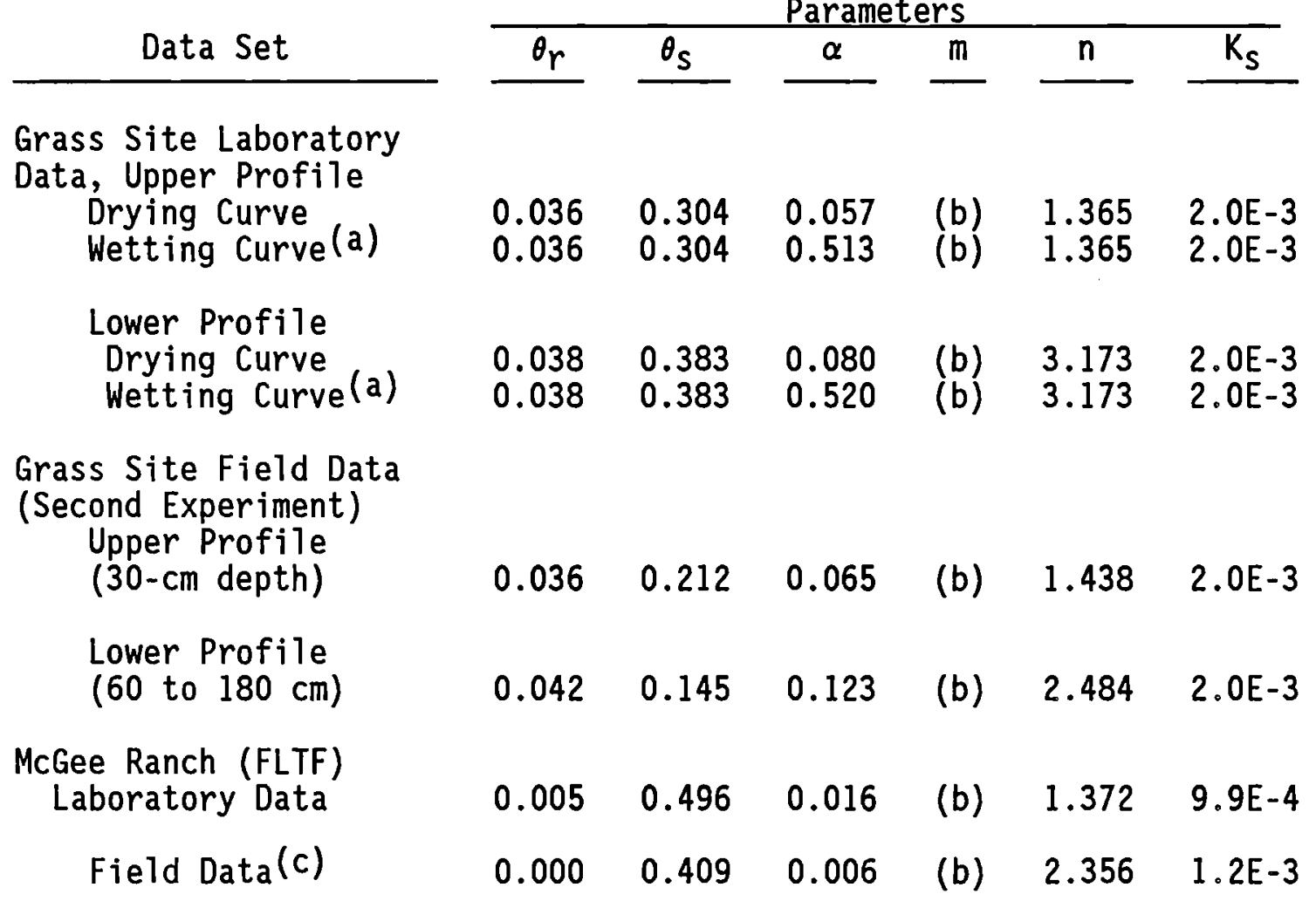

(a) Hypothetical wetting curves generated by scaling the $\alpha$ parameter determined from laboratory data so that the wetting curves bracket the field-measured water retention characteristics.

(b) Mualem-based restruction, $m=1-1 / n$.

(c) From the first experiment conducted at the McGee Ranch (Rockhold, Fayer, and Gee 1988). 


\subsection{SITE WATER BALANCE CONSIDERATIONS}

Table 6.1 lists water balance parameters for selected locations at the Hanford Site for the year July 1987 through June 1988. In calculating the annual evapotranspiration and the annual drainage (except where measured directly), we have assumed there has been no runoff since the soils at the test locations cited are generally coarse-textured and water infiltration rates exceeded precipitation and snowmelt rates during the test period. Table 6.2 shows the ratio of actual evapotranspiration to predicted potential evapotranspiration calculated from the neutron probe and weighing lysimeter data for the BWTF.

Figure 6.1 shows the monthly rainfall distribution for a 68-year period at the Hanford Site (based on historical data for 1912 through 1980 from the HMS). The data clearly show that wintertime precipitation dominates the Hanford Site and is likely responsible for net infiltration of water at locations where the soil is coarse textured and plant cover is sparse and/or shallow rooted. Figure 6.2 shows the monthly potential evapotranspiration for the past 10 years (1978 through 1987) calculated using a standard Penmantype calculation, which requires knowledge of daily temperature, radiation, and wind speed (Fayer, Gee, and Jones 1986, and reference there in to Doorenbos and Priutt methods for calculations of potential evapotranspiration). Figure 6.3 compares calculated potential evapotranspiration and precipitation for the HMS, for 1978 through 1987. Figure 6.4 shows the correlation between potential evapotranspiration (PET) and precipitation for the same period. The coefficient of determination ( $r^{2}$ value) between PET and precipitation is 0.005 , suggesting that these two variables are not correlated.

The data from Tables 6.1 and 6.2 also illustrate that estimates of potential evapotranspiration (as computed from climate variables alone) are virtually useless in predicting actual evapotranspiration and drainage at the Hanford Site. This is because when soil or plant surfaces are dry, as is the case much of the time at the Hanford Site, they no longer evaporate water to the atmosphere at the potential rate. For coarse, bare soils, the soil 
TABLE 6.1. Water Balance Parameters for July 1987 Through June 1988

\begin{tabular}{|c|c|c|c|c|c|}
\hline Location & $\begin{array}{c}\text { Surface } \\
\text { Condition } \\
\end{array}$ & $\begin{array}{c}\text { Precipitation, } \\
\mathrm{cm} / \mathrm{yr}\end{array}$ & $\begin{array}{l}\text { Storage } \\
\text { Change, } \\
\mathrm{cm} / \mathrm{yr}\end{array}$ & $\begin{array}{l}\text { Drainage, } \\
\mathrm{cm} / \mathrm{yr}\end{array}$ & $\begin{array}{l}\text { Evapotran- } \\
\text { spiration, } \\
\mathrm{cm} / \mathrm{yr} \\
\end{array}$ \\
\hline \multicolumn{6}{|l|}{ BWTF } \\
\hline $\begin{array}{l}\text { South caisson } \\
\text { North weighing } \\
\text { caisson }\end{array}$ & $\begin{array}{l}\text { Bare } \\
\text { Bare }\end{array}$ & $\begin{array}{l}12.5 \\
12.5\end{array}$ & $\begin{array}{l}-1.9 \\
-1.9\end{array}$ & $\begin{array}{l}3.1 \\
4.1\end{array}$ & $\begin{array}{r}10.3 \\
9.3\end{array}$ \\
\hline $\begin{array}{l}\text { South weighing } \\
\text { caisson }\end{array}$ & Vegetated & 12.5 & 0.5 & 0 & 12.0 \\
\hline \multicolumn{6}{|l|}{ CWTF } \\
\hline 10 lysimeters & Bare & 12.5 & -1.9 & 4.6 & 9.8 \\
\hline Grass Site & Vegetated & 11.5 & 0.5 & $(2.0)^{(a)}$ & 10.0 \\
\hline
\end{tabular}

(a) Estimated from Buried Waste Test Facility observations.

TABLE 6.2. Ratio of Actual Evapotranspiration (ET) to Predicted Potential Evapotranspiration (PET) (a) for July 1987 Through June 1988

Location

BWTF

South caisson

North weighing lysimeter

South weighing lysimeter

0.06

0.05

0.07

CWFT

10 lysimeters

0.06

Grass Site

0.06

(a) PET for all 300 North Area locations is assumed to be the same as at the Hanford Meteorological Station and equal to $163.2 \mathrm{~cm}$. 


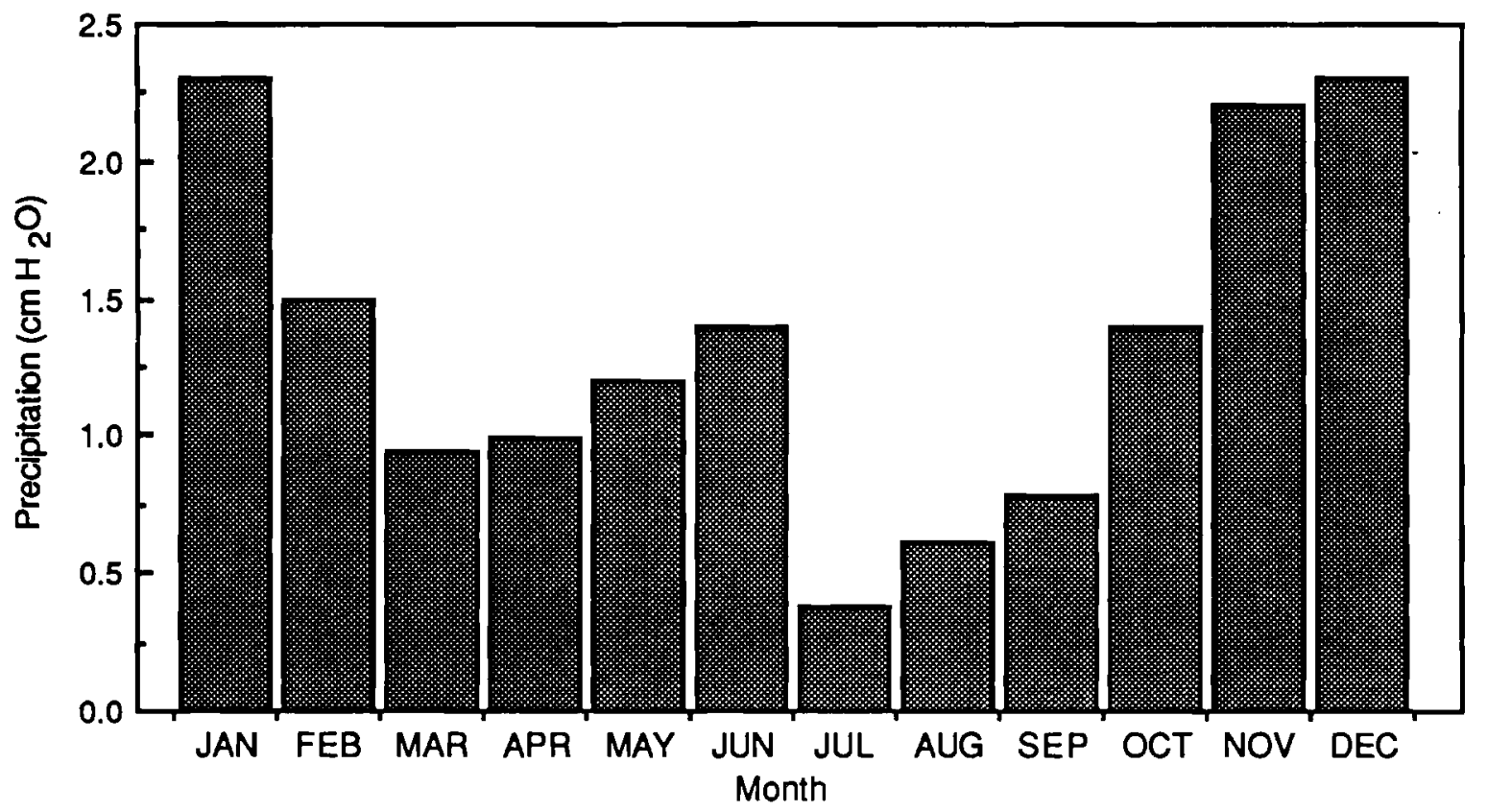

FIGURE 6.1. Monthly Rainfal1 Distributions Determined from Long-Term Averages (1912 through 1980) at the Hanford Site (after Stone et al. 1983)

surface dries relatively quickly and tends to form an armor or highly resistive layer that prevents rapid water losses except immediately after rainfalls. During the summer, the actual evapotranspiration is only a small fraction of the potential rate. Because most precipitation at the Hanford Site occurs during winter when the potential evaporation is lowest, the chance for water to be stored and eventually drain is markedly increased. Coarse (e.g., sandy or gravelly) soils having water storage capacities of only a few centimeters of water in the top meter of the soil profile are more susceptible to drainage than fine-textured (e.g., silty or clayey) soils that often have storage capacities exceeding the annual precipitation by several times (e.g., 40 to $60 \mathrm{~cm}$ of water).

The actual storage capacity of the soil is a function not only of the soil texture, but of $\mathrm{plant}$ cover and the distribution of precipitation. If deep-rooted plants are present, the effective storage capacity of the soil is increased because plant roots will intercept much, if not all, of the infiltrating water before it moves below the root zone. Thus, the presence of 


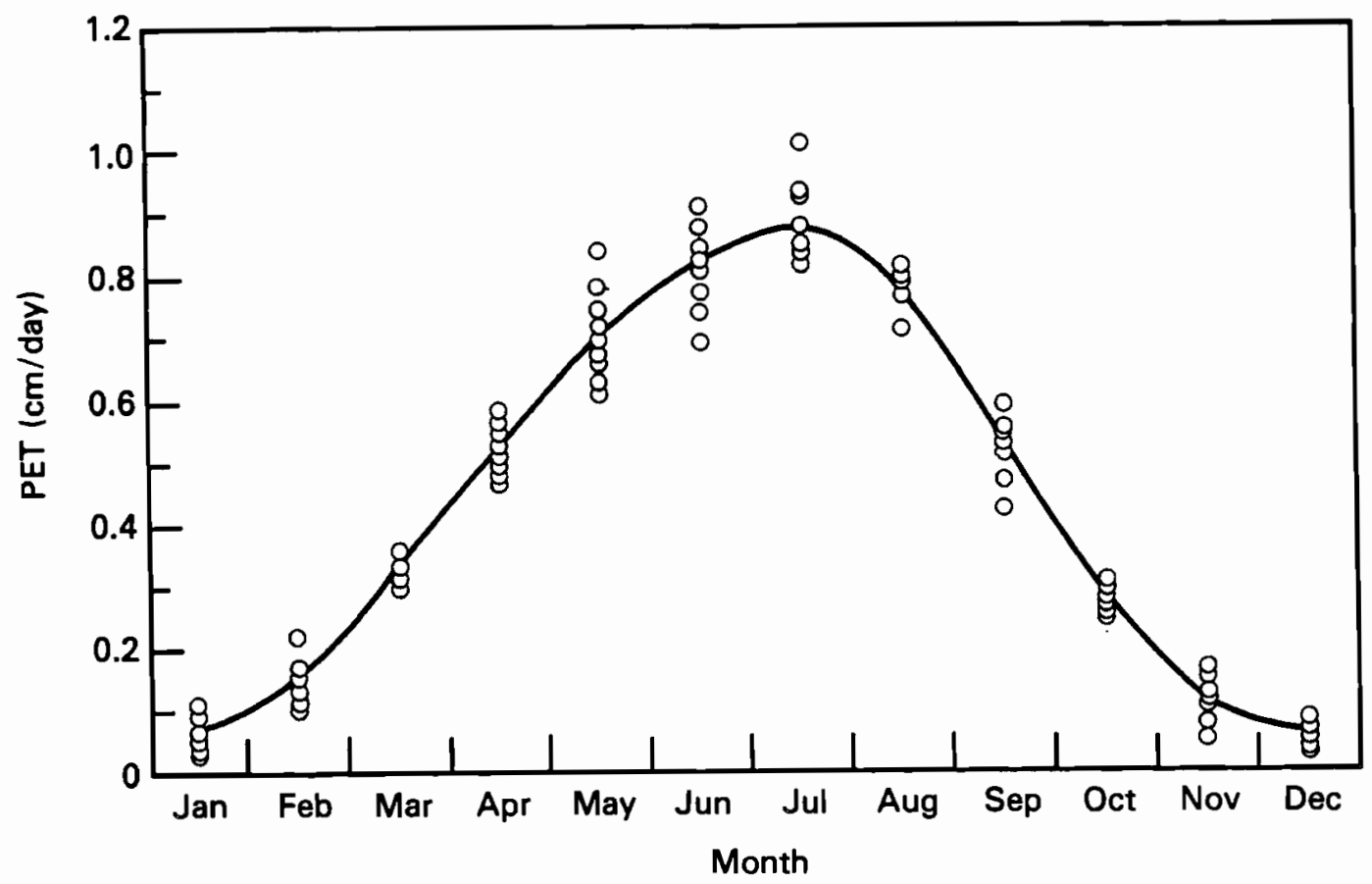

FIGURE 6.2. Average Daily Potential Evapotranspiration (PET) at the Hanford Meteorological Station Determined for Each Month of the Year Using the Penman Model for 1978 Through 1987

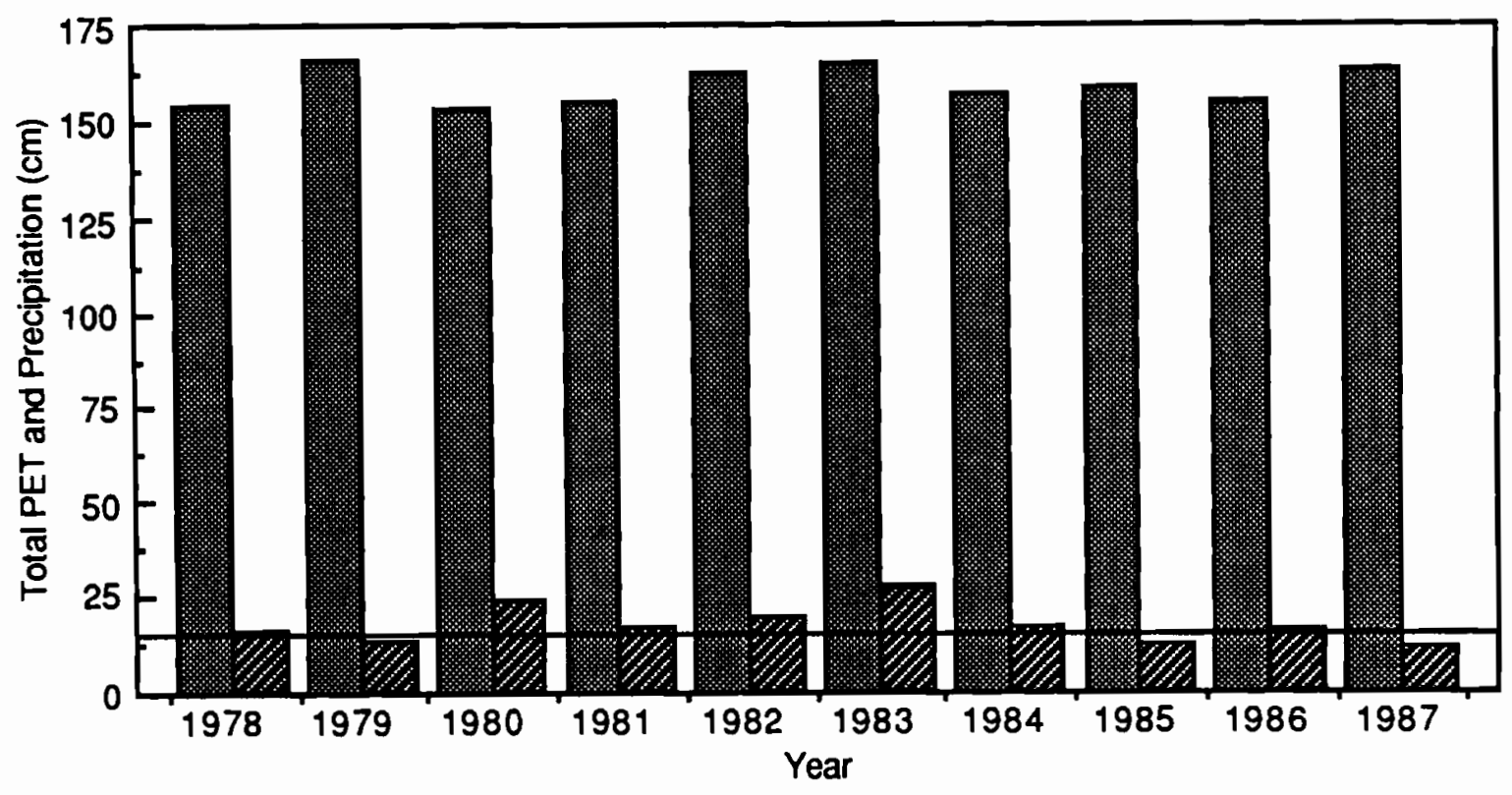

FIGURE 6.3. Total Potential Evapotranspiration (PET) and Precipitation (crosshatch) at the Hanford Meteorological Station for 1978 Through 1987. The solid line represents the long-term average $(16 \mathrm{~cm} / \mathrm{yr})$ precipitation for the Hanford Site. 


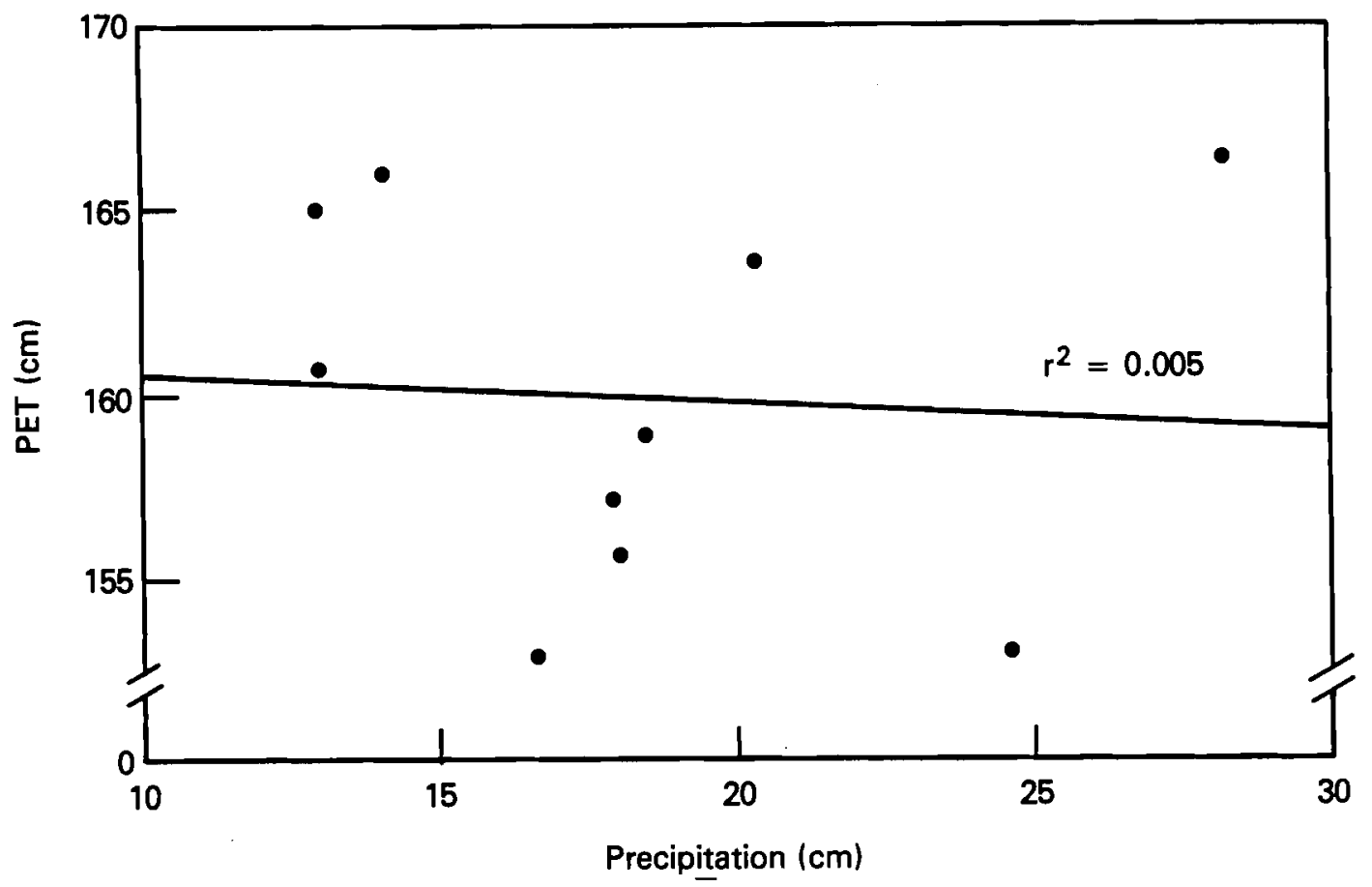

FIGURE 6.4. Correlation Between Potential Evapotranspiration (PET) and Precipitation for 1978 Through 1987

plants can significantly increase the storage capacity of both coarse and fine-textured soils. In a semiarid climate, as exists at the Hanford Site, a coarse soil with $\mathrm{plant}$ cover may in some years have adequate storage capacity to prevent drainage and in other years not. For example, change of vegetation from deep-rooted sagebrush to shallow-rooted cheatgrass, which often occurs after a fire, can dramatically change the storage capacity of a soil. If the grass root depth is only a few tens of centimeters and winter precipitation penetrates to depths of a meter or more, then the chances of deep drainage occurring are greatly enhanced. Such conditions (i.e., grass cover, lack of deep-rooted plants, coarse soils) have been present at the Grass Site for the past 5 years or more.

The distribution of precipitation, as well as its quantity, determine if the storage capacity of a soil will be exceeded in any given year. If the wintertime precipitation were doubled or if a large snowfall occurred by rapid snowmelting, the storage capacity of most coarse-textured soils at the Hanford Site would be exceeded and drainage would likely occur. 
It is clear from the previous discussion that the storage capacity of a soil is a dynamic property. Estimates of the storage capacity of a given soil must be made on a site-specific basis and must include information about the plant cover and the distribution of precipitation. Models used to predict the water balance of a site must address these factors to be successful. The UNSAT-H model (Fayer, Gee, and Jones 1986) includes all of the key parameters (soil hydraulic properties, plant characteristics, and climatic variables) and has been used successfully to assess the dynamic nature of water balance parameters for selected conditions at the Hanford Site.

In summary, the following observations made related to Hanford Site water balance can be made.

1. Lysimeter measurements have quantified drainage rates ranging from 0 to more than $10 \mathrm{~cm} / \mathrm{yr}$. The range is a primary function of surface cover (from deep-rooted vegetation to bare soil) conditions. Drainage measured from July 1987 to June 1988 in BWTF and CWTF lysimeters located north of the 300 Area was influenced by presentand previous-year (below normal) precipitation; bare-soil drainage from July 1987 through June 1988 ranged from $3 \mathrm{~cm} / \mathrm{yr}$ to $5 \mathrm{~cm} / \mathrm{yr}$. Previous-year drainage values exceeded $10 \mathrm{~cm} / \mathrm{yr}$ as a consequence of higher wintertime precipitation.

2. Water storage changes from July 1987 through June 1988 for all lysimeter sites and the Grass Site were relatively small (ranging from $4 \mathrm{~cm}$ to $5 \mathrm{~cm}$ total storage) compared to previous years' records (more than $8 \mathrm{~cm}$ ). The smaller water storage changes are also attributed to lower precipitation.

3. Water storage measurements at the 200 East lysimeter site show that bare surface conditions have significantly reduced summertime water storage losses compared to water storage losses from vegetated surfaces.

4. Potential evapotranspiration is not a reliable estimate of actual evaporation or evapotranspiration at the Hanford Site. There was no correlation between potential evapotranspiration and variation in precipitation for the past 10 years (1978 to 1988). Reliable 
estimates of actual evapotranspiration cannot be obtained directly from estimates of precipitation or potential evapotranspiration. These estimates are best made by quantifying drainage rates, precipitation, and soil-water storage changes.

5. There is still relatively large uncertainty in predicting natural recharge for specific conditions at the Hanford Site. Additional lysimeter tests and continued monitoring of the present lysimeter facilities appear to offer the best approach to quantifying natural recharge over the expected range of conditions that exist at the Hanford Site. 


\subsection{REFERENCES}

Arya, L. M., and J. F. Paris. 1981. "A Physicoempirical Model to Predict the Soil Moisture Characteristics from Particle-Size Distribution and Bulk Density Data." Soil Sci. Soc. Am. J. 45:1023-1030.

Fayer, M. J., G. W. Gee, and T. L. Jones. 1986. UNSAT-H Version 1.0: Unsaturated Flow Code Documentation and Applications for the Hanford Site. PNL-5899, Pacific Northwest Laboratory, Richland, Washington.

Gee, G. W. 1987. Recharge at the Hanford Site: Status Report. PNL-6403, Pacific Northwest Laboratory, Richland, Washington.

Gee, G. W., and P. R. Heller. 1985. Unsaturated Water Flow at the Hanford Site: A Review of Literature and Annotated Bibliography. PNL-5428, Pacific Northwest Laboratory, Richland, Washington.

Gee, G. W., and T. L. Jones. 1985. Lysimeters at the Hanford Site: Present Use and Future Needs. PNL-5578, Pacific Northwest Laboratory, Richland, Washington.

Green, R. E., L. R. Ahuja, and S. K. Chong. 1986. "Hydraulic Conductivity, Diffusivity, and Sorptivity of Unsaturated Soils: Field Methods." Methods of Soil Analysis, Part 1. 2nd ed., ed. A. K1ute, pp. 771-798. American Society of Agronomy, Madison, Wisconsin.

Hillel, D. 1982. Introduction to Soil Physics. Academic Press, New York, New York, p. 78.

Jones, T. L., R. J. Serne, and A. P. Toste. 1988. Special Waste-Form Lysimeter-Arid: Three-Year Monitoring Report. PNL-6400, Pacific Northwest Laboratory, Richland, Washington.

Kirkham, R. R., G. W. Gee, and T. L. Jones. 1984. "Weighing Lysimeters for Long-Term Water Balance Investigations at Remote Sites." Soil Sci. Soc. Am. J. 48:1203-1205.

Kirkham, R. R., G. W. Gee, and J. L. Downs. 1987. Field Lysimeter Test Facility for Protective Barriers: Experimental Plan. PNL-6351, Pacific Northwest Laboratory, Richland, Washington.

Klute, A. 1986. "Water Retention: Laboratory Methods." Methods of Soil Analysis, Part I. 2nd ed., ed A. Klute, pp. 635-662. American Society of Agronomy, Madison, Wisconsin.

Klute, A., and C. Dirksen. 1986. "Hydraulic Conductivity and Diffusivity: Laboratory Methods." In Methods of Soil Analysis, Part I. 2nd ed., ed. A. Klute, pp. 687-734. American Society of Agronomy, Madison, Wisconsin. 
Mandelbrot, B. B. 1982. The Fractal Geometry of Nature. W. H. Freeman, San Francisco, Cal ifornia.

Mandelbrot, B. B., D. E. Passoja, and A. J. Paullay. 1984. "Fractal Character of Fracture Surfaces of Metals." Nature, Vol. 308, pp. 721-722.

Mualem, Y. 1976. "A New Model for Predicting the Hydraulic Conductivity of Unsaturated Porous Media." Water Resour. Res. 12(3):513-522.

Richards, L. A. 1931. "Capillary Conduction of Liquids in Porous Mediums." Physics $1: 318-333$.

Rockhold, M. L., M. J. Fayer, and G. W. Gee. 1988. Characterization of Unsaturated Hydraulic Conductivity at the Hanford Site. PNL-6488, Pacific Northwest Laboratory, Richland, Washington.

Stone, W. A., J. M. Thorp, 0. P. Gifford, and D. J. Hoitink. 1983.

Climatological Summary for the Hanford Area. PNL-4622, Pacific Northwest Laboratory, Richland, Washington.

Turcotte D. L. 1986. "Fractals and Fragmentation." J. Geophys. Research 91 (B2) : 1921-1926.

U.S. Department of Energy (DOE). 1987. Final Environmental Impact Statement. Disposal of Hanford Defense High-Level, Transuranic and Tank Wastes, Hanford Site, Richland, Washington. D0E/EIS-0113, Vol. 3 (Appendix M). U.S. Department of Energy, Washington, DC.

Vachaud, G., A. Passerat de Silans, P. Balabanis, and M. Vaiclin. 1985. "Temporal Stability of Spatically Measured Soil Water Probability Density Function." Soil Sci. Soc. Am. J. 49:822-828.

van Genuchten, M. Th. 1978. Calculating the Unsaturated Hydraulic Conductivity with a New Closed-Form Analytical Model. Report 78-WR-08, Department of Civil Engineering, Princeton University, Princeton, New Jersey, pp. 63 .

Walter, M. B., M. J. Graham, and G. W. Gee. 1984. A Field Lysimeter Facility for Evaluating the Performance of Commercial Solidified Low-Level Waste. PNL-5253, Pacific Northwest Laboratory, Richland, Washington. 


\section{APPENDIX A}

\section{DATA ARCHIVING PROCEDURES}


APPENDIX A

DATA ARCHIVING PROCEDURES

\section{DATA BASE OBJECTIVES}

Pacific Northwest Laboratory (PNL) is working under direction from the Westinghouse Hanford Company, Environmental Technology Group, to collect, analyze, and store data needed for performance assessment activities. The information and computer-encoded mathematical models needed to assess performance of proposed waste remediation and disposal options will be assembled in a quality-assured and consistent manner for retrieval and analysis. Major concerns that must be addressed include ensuring that 1) data are archived and documented adequately, 2) data are accessible through the Hanford Site computer network, and 3) the Hanford Site Performance Assessment (HSPA) data base is compatible with other Hanford Site data bases.

The data are currently stored and accessed using RS/1 software.(a) RS/1 is a data analysis system with graphical, statistical, and data management capabilities. The software is user friendly and can be operated both on the VAX (b) and IBM(c) PC/AT computer systems. Most data now reside in the HSPA MicroVAX ${ }^{(b)}$, which has the advantages of large storage capacity and multiuser capabilities. Accessing the data using RS/1 on the IBM PC/AT offers the advantages of fast response time for data entry as a single user and, most importantly, compatibility with data collection software. Data are easily transferred from RS/1 on the IBM PC/AT to final storage on the VAX computer system. The organization of the data in this system and the current procedures for storage and retrieval are described in this report.

(a) RS/1 (The Research System) is a registered tradename of BBN Research Systems, Sunnyvale, Cal ifornia.

(b) VAX and MicroVAX are registered tradenames of the Digital Equipment Corporation (DEC), Maynard, Massachusetts.

(c) IBM is a registered tradename of the International Business Machines Corp., Boca Raton, Florida. 


\section{STANDARD INTERFACE TO OTHER HANFORD SITE DATA BASES}

To make credible assessments of performance of waste remediation and disposal systems for the Hanford Site, a11 relevant data must be accessible. In addition to the HSPA data base, other data bases exist for a variety of Hanford Site data (e.g., the Hanford Site Protective Barriers Program data base, Hanford Site groundwater monitoring data base, Hanford Site compliance data base, and the Westinghouse Hanford Company ROCSAN data base (containing granulometric data).

It is not realistic to assume that any one data base contains and adequately documents all required data. Thus, either "switchboard" software must be developed to enable the HSPA data base to interface with, and access, information from the other data bases, or the HSPA data base must be compatible with an existing data base management system.

of considerable interest to all Hanford Site environmental data management systems is the development of a new data base management system that will provide a geographically based retrieval system. A Geographic U.S. Information System (GIS) for Hanford, Pasco Basin, and/or Yakima Firing Range data is being developed at PNL, with funding provided by the U.S. Department of Defense. Among other features, this GIS will use a standard software interface to access different data bases. A comprehensive approach appears to provide the most cost-effective way for performance assessment personne 1 to interface with other data bases. During the next several years, the activities of the GIS development will be reviewed, and plans will be made to implement features of the GIS into the HSPA data base.

\section{CURRENT DATA MANAGEMENT AND PROCEDURES}

The objective of the HSPA data base is to provide the means to centralize, critically review, store, and retrieve reliable and consistent data to support various waste remediation and disposal studies at the Hanford Site. Several types of data have been, and are currently being, collected to support the calibration and validation of groundwater pathway models. Data stored in the HSPA data base are 1 isted in Table A.1 according to type of data, method of collection, and location of data collection. 
IABLE A.1. Types of Data Collected for the HSPA Data Base

Type of Data

Soil Moisture

Drainage

Precipitation

Soil Water Potential

Soi1 Temperature

Wind Speed and Direction

Air Temperature
Relative Humidity
$\begin{aligned} & \text { Saturated Vapor Pres- } \\ & \text { sure }\end{aligned}$

Solar Radiation

Phenology

Vegetative Cover

Evaporation or Evapotranspiration Rates
Method of collection

Neutron probe or gravimetric

Physical measurement

Tipping bucket ${ }^{(a)}$

Weighing Lysimeter(a)

Collection-type (nonrecording)

Tensiometers

Thermocouples (a)

Anemometer (a)

Thermistor (a)

Humidity transducer (a)

Calculated from

temperature and

relative humidity (a)

Pyranometer(a)

Observations

Observations

Lysimeter weight changes
BWTF Grass Site

$\mathrm{X}$

$\mathrm{X}$

$x$

$\mathrm{X}$

$X$

$x \quad x$

$x \quad x$

$x \quad x$

$X \quad X$

$x \quad x$

$x$

$x$

$x \quad x$

$x \quad x$

$X \quad X$

$x$

(a) Connected to data logger.

Work on the HSPA data base currently involves collection of water balance data from the Buried Waste Test Facility (BWTF) and the Grass Site. Numerous reports also document the hydraulic conductivity and water retention data previously gathered for Hanford Site sediments (Enfield, Hsieh, and Warrick 1973; Hsieh, Browne11, and Reisenauer 1973; Hsieh and Enfield 1974; Cass, Campbe11, and Jones 1981; Gee and Campbe11 1980; Gee et a1. 1981; Gee 
and Kirkham 1984; Sisson and Lu 1984; and Heller, Gee, and Myers 1985). In addition, in situ hydraulic conductivity data have been collected at the BWTF and Grass Site and adjacent to the 200 Areas at the McGee Ranch site. These data are incorporated into the data base as needed. Relevant computer codes are archived (at this time, only UNSAT-H Version 1.0).

This appendix discusses the current procedures and software for collection, storage, and archiving of performance assessment data and outlines plans and procedures for data management using the HSPA MicroVAX.

\section{DATA BASE DESIGN}

Performance assessment data are stored and accessed using a statistical analysis system that operates on both the IBM PC/AT and VAX computer systems. This flexibility is important because the software used for automated data collection and for editing data files operates on IBM systems; data collected in this manner can be processed directly into RS/1 by the IBM PC/AT. The software, RS/1, is specifically designed for information handling. Within the data base, information is stored in hierarchical directories, as shown in Figure A.1. Data are stored according to data type and geographical location.

Data collected are transferred directly from the IBM PC/AT data collection station to the HSPA MicroVAX. The framework for data collection, processing, quality assurance, storage, and access is shown in Figure A.2, and is discussed in detail in the following sections.

\section{Procedures for Incorporating Neutron Probe Data}

Soil moisture data are collected using neutron probes at various study areas on the Hanford Site. As discussed in the main body of the report, measurements of soil water using the neutron probe have been taken periodically in the 300 Area BWTF since 1978, at the Grass Site since 1983, and at the 200 East lysimeter site since February of 1988. Descriptions of these sites are provided in Section 2.0. The neutron probe field measurements 


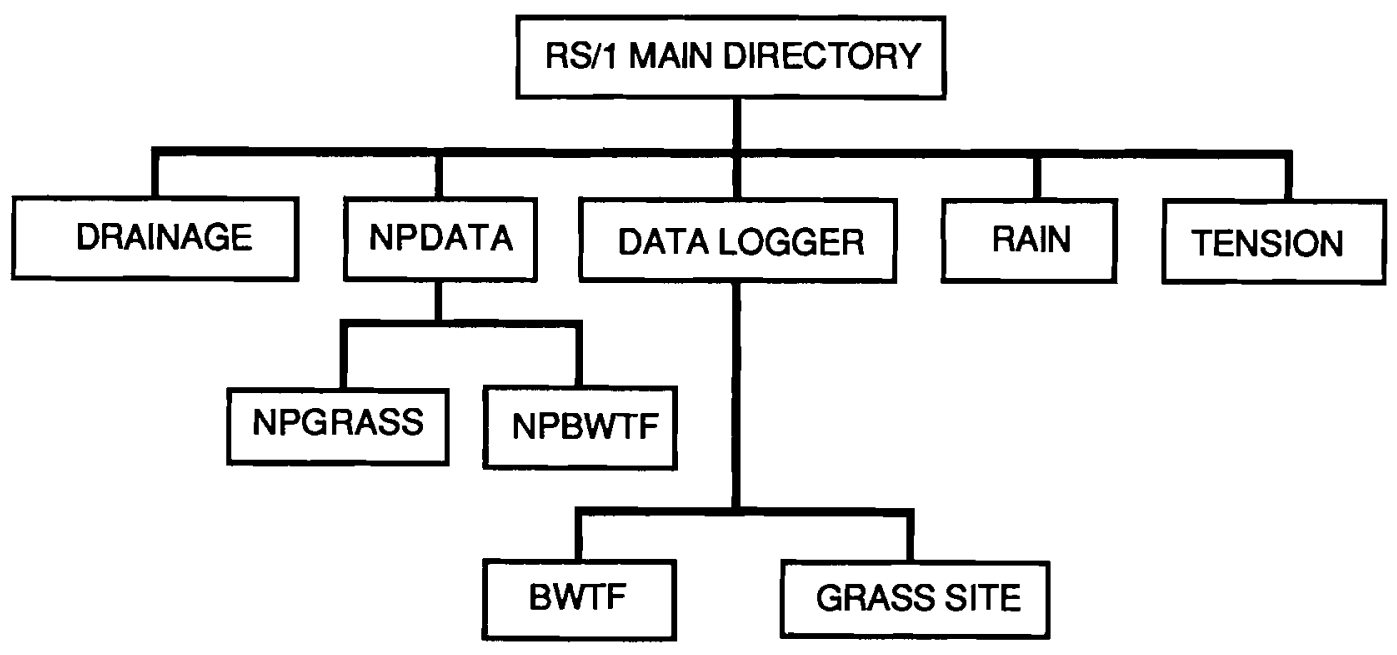

S8809 116001

\begin{abstract}
THE MAIN DIRECTORY CONTAINS A LISTING OF ALL OTHER DIRECTORIES AS WELL AS THE INDIVIDUAL USER DIRECTORIES

THE DRAINAGE OIRECTORY CONTAINS DRAINAGE DATA FOR THE BWTF SITE ONLY AT THIS TIME THE NPDATA DIRECTORY CONTAINS THE SUMMARY TABLES FOR NEUTRON PROBE DATA COLLECTED AT THE BWIF AND GRASS SITES

THE NPGRASS DIRECTORY CONTAINS RAL NEUTRON PROBE COUNT AND PERCENT MOISTURE DATA FOR THE GRASS SITES

THE NPBWTF DIRECTORY CONTAINS RAH COUNT AND PERCENT MOISTURE DATA FOR THE BWTF SITE THE DATA LOGGER DATA CONTAINS DIRECTORIES FOR EACH OF THE SITES WHERE DATA LOGGERS AUTOMATICALLY COLLECT DATA FOR A NUMBER OF SENSORS

THE BWTF DIRECTORY CONTAINS THE FILES OF DATA LOGGER DATA FOR THE BWTF SITE ORGANIZED BY CALENDAR YEAR

THE GRASS SITE DIRECTORY CONTAINS THE FILES OF DATA LOGGER DATA FOR THE GRASS SITE ORGANIZED BY CALENDAR YEAR

THE RAIN DIRECTORY CONTAINS SUMMARIES OF THE RAIN DATA CONTAINED IN THE BWTF AND GRASS-SITE DIRECTORIES

THE TENSION DIRECTORY CONTAINS SOIL WATER POTENTIAL DATA COLLECTED AT BOTH THE GRASS SITE AND BWTF
\end{abstract}

FIGURE A.1. Directory and File Organization for Water Balance Data in the RS/1 Data Base

are recorded in the project notebook and stored on a digital readout unit (data logger) connected to the probe. The information on the digital readout unit is transmitted to an IBM PC/AT in PNL facilities. The file is then edited to a specific format and transmitted to the HSPA MicroVAX system. This method of data transfer avoids errors that might be generated during manual data entry. The raw data files for the current year are stored on 


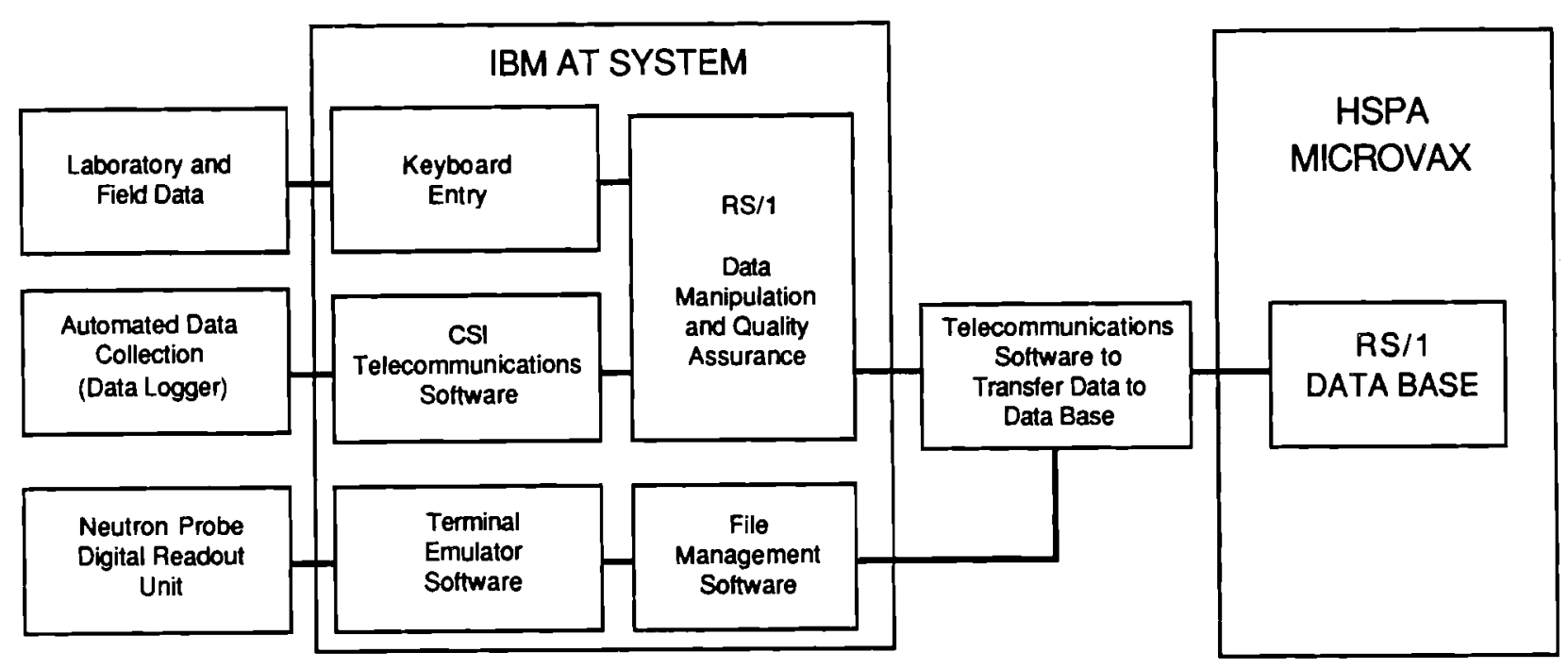

$\$ 8809116002$

FIGURE A.2. Framework for Collecting, Processing, Storing, and Accessing Water Balance Data

backup floppy disks and on the VAX system in addition to being documented in the project notebook. Using RS/1 procedures (simple computer programs written in the RS/1 command language), the raw data are read into tables and analyzed to obtain percent moisture and total centimeters of water storage at each depth. Averages of these values are then calculated and entered into summary tables that reflect total storage in the soil profile.

Within the data base, the neutron probe data for the current calendar year are organized first by site and then chronologically. Neutron probe data for a specific site are entered in a directory for that site. The file names of the tables in the RS/1 directories for neutron probe data indicate the calendar date on which the data were collected and include a prefix letter indicating the site at which the data were collected and a suffix letter indicating whether the table contains raw counts $(A)$ or percent moisture (C). Examples of these formats are shown in Figures A.3 and A.4. Tables containing summaries of the data collected from each site are stored in a first-leve1 directory (the 'NPDATA' directory) for easier access by all users. 
G26MAY87A $17 R \times 28 C$

15-SEP-87 10:25 Page 1

Noutron Probe Data for the Grass Site on May 20, 1987

61-JUL-87 1 ST. MEAN 2 END MEAN 3 DEPTH. 4 HOLE 15 HOLE 2 BNW $61374 P .75-76$ STANDARD STANDARD

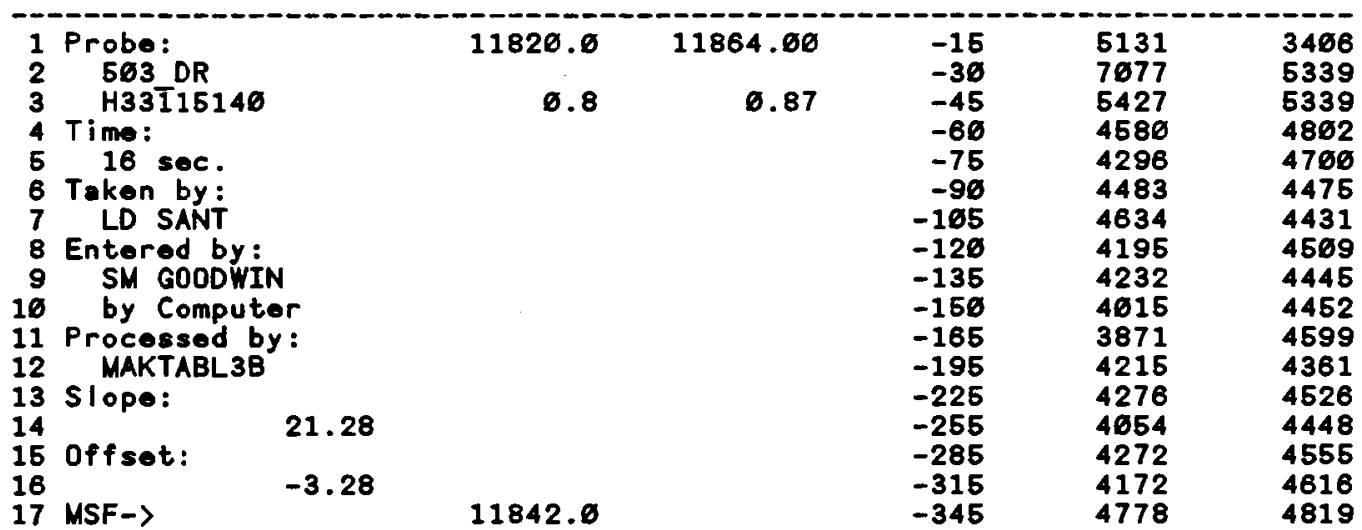

$61-J U L-87$ BNW 51374 P. 75-76

6 HOLE 37 HOLE 48 HOLE 59 HOLE 6 10 HOLE 7

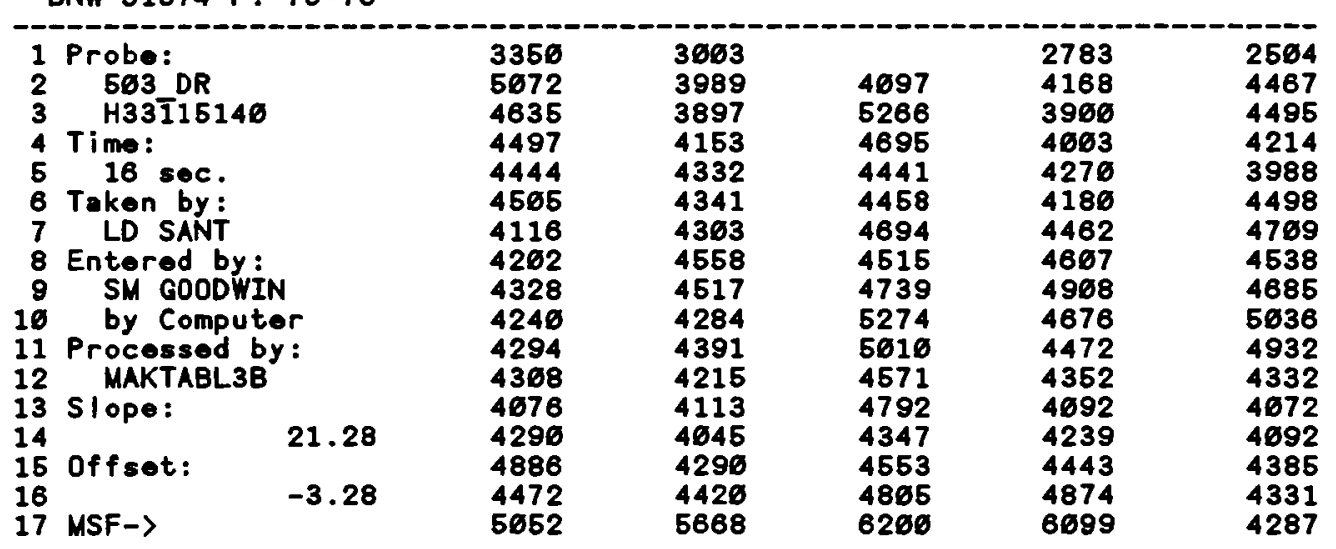

FIGURE A.3. Example of Neutron Probe Raw Count Data Stored Using RS/1 Format 
Neutron Probe Data for the Grass Site on May 26, 1987

61-JUL-87 11 HOLE 812 HOLE 913 HOLE 1614 HOLE 11 15 HOLE 12 BNW 51374 P. 75-76

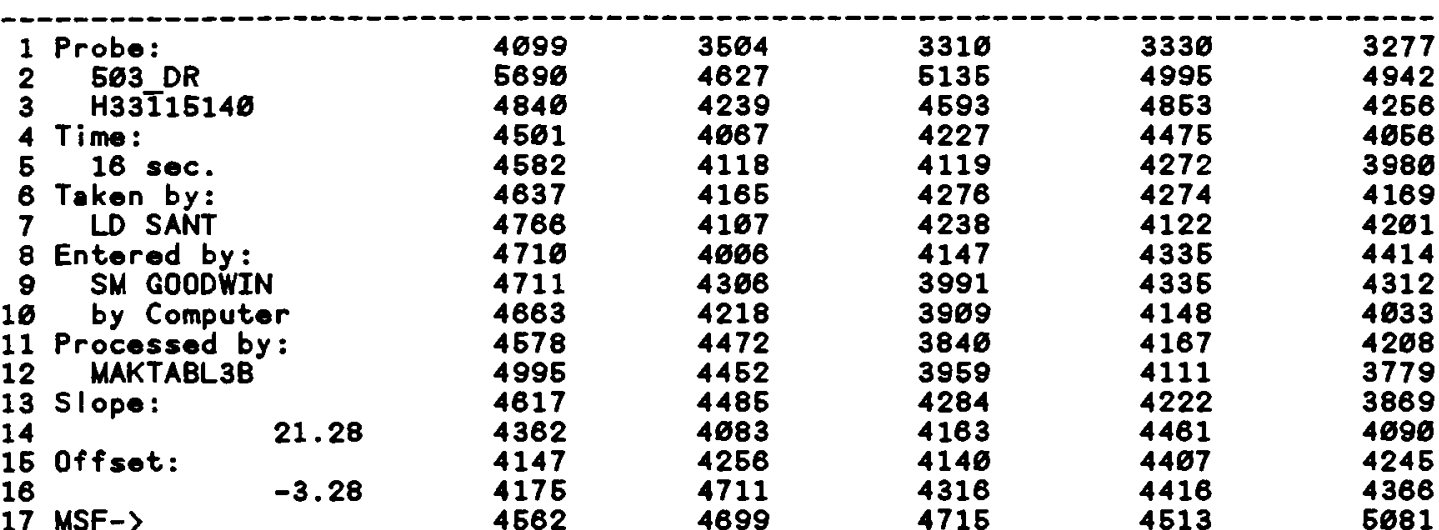

16 HOLE $13 \quad 17$ HOLE $14 \quad 18$ HOLE $15 \quad 19$ HOLE $16 \quad 20$ HOLE 17 BNW 51374 P. $75-78$

1 Probe:
2 5ø3 DR
3 H33I16140
4 Time:
6 16 sec.
6 Taken by:
7 LD SANT
8 Entered by:
9 SM GOODWIN
10 by Computer
11 Processed by:
12 MAKTABL3B
13 SIope: $\quad 21.28$
14 Offset: $\quad-3.28$
15 MSF->

$\begin{array}{lllll}3482 & 3692 & 3762 & 3237 & 385 \sigma \\ 4736 & 5161 & 5318 & 4848 & 5184 \\ 4327 & 4868 & 4521 & 4363 & 4562 \\ 4266 & 4492 & 4173 & 4656 & 4165 \\ 3996 & 4434 & 4261 & 3961 & 4169 \\ 4674 & 4371 & 4136 & 3928 & 4215 \\ 4666 & 4192 & 4216 & 3897 & 4117 \\ 4469 & 4217 & 4187 & 3965 & 4657 \\ 4596 & 4181 & 4563 & 4189 & 4168 \\ 4376 & 4222 & 4772 & 4681 & 4692 \\ 4473 & 4486 & 4461 & 4678 & 4267 \\ 4661 & 4776 & 4117 & 4245 & 4635 \\ 4436 & 4634 & 4697 & 4179 & 4265 \\ 4339 & 4653 & 4168 & 4699 & 4136 \\ 4521 & 4316 & 4316 & 4654 & 4459 \\ 4542 & 4365 & 4179 & 4368 & 4420 \\ 5163 & 4743 & 4656 & 4726 & 4896\end{array}$

FIGURE A.3. (contd) 
Neutron Probe Data for the Grass Site on May 20, 1987 91-JUL-87
BNW 51374 P. $75-76$

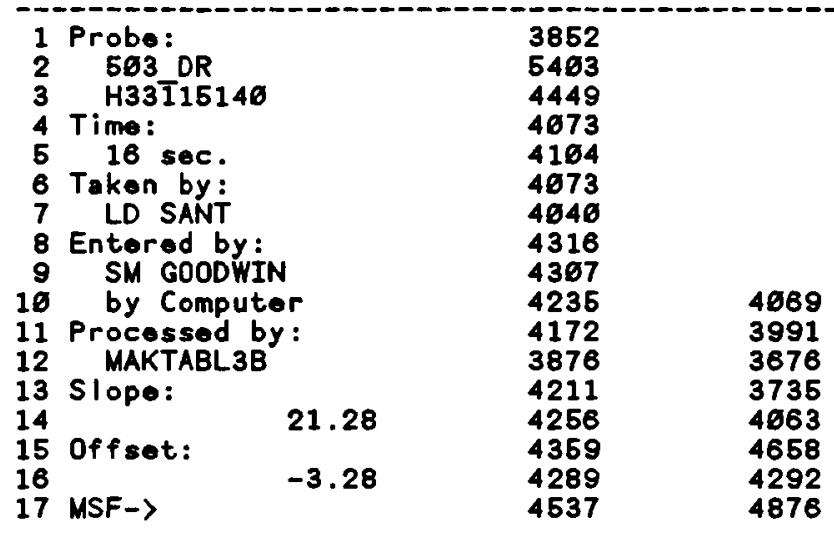

๑1-JUL-87 BNW 51374 P. 75-76

26 HOLE 2327 HOLE 2428 HOLE 25 1 Probo:

$2503-O R$

3 H33T15140

4 Time:

$516 \mathrm{sec}$.

6 Taken by:

7 LD SANT

8 Enterod by:

9 SM GOODWIN

10 by Computer

11 Processed by

12 MAKTABL3B

13 SI Ope:

16 offset

21.28

16

$-3.28$

17 MSF->

FIGURE A.3. (contd) 
Neutron Probe Data for the Grass Site on May 20, 1987

\begin{tabular}{|c|c|c|c|c|c|c|}
\hline & $\begin{array}{l}\text { ס1-JUL-87 } \\
\text { BNW } 51374 \text { P. } 75-76\end{array}$ & $\begin{array}{l}1 \text { ST. MEAN } \\
\text { STANDARD }\end{array}$ & $\begin{array}{l}2 \text { END MEAN } \\
\text { STANDARD }\end{array}$ & 3 DEPTH & 4 HOLE 1 & 5 HOLE 2 \\
\hline & $\begin{array}{l}\text { Probe: } \\
\text { 563 DR } \\
\text { H33I15140 } \\
\text { Time: } \\
16 \text { sec. } \\
\text { Token by: } \\
\text { LD SANT } \\
\text { Entered by: } \\
\text { SM GOODWIN } \\
\text { by Computer } \\
\text { Processed by: } \\
\text { MAKTABL3B } \\
\text { Slope: } \quad 21.28 \\
\text { Offset: } \quad-3.28 \\
\text { MSF-> }\end{array}$ & $\begin{array}{r}11820.6 \\
0.8\end{array}$ & $\begin{array}{r}11864.60 \\
6.87\end{array}$ & $\begin{array}{l}-15 \\
-36 \\
-45 \\
-66 \\
-75 \\
-96 \\
-165 \\
-126 \\
-135 \\
-156 \\
-165 \\
-195 \\
-225 \\
-255 \\
-285 \\
-315 \\
-345\end{array}$ & $\begin{array}{l}5.946375 \\
9.437325 \\
6.472285 \\
4.956231 \\
4.439885 \\
4.775923 \\
5.647269 \\
4.258389 \\
4.324878 \\
3.934936 \\
3.676163 \\
4.294329 \\
4.463945 \\
4.865613 \\
4.396757 \\
4.217658 \\
5.366836\end{array}$ & $\begin{array}{l}2.846561 \\
6.314166 \\
6.314156 \\
5.349164 \\
5.165871 \\
4.761547 \\
4.682479 \\
4.822645 \\
4.767637 \\
4.726216 \\
4.984374 \\
4.656696 \\
4.853194 \\
4.713628 \\
4.965367 \\
5.614923 \\
5.379713\end{array}$ \\
\hline
\end{tabular}

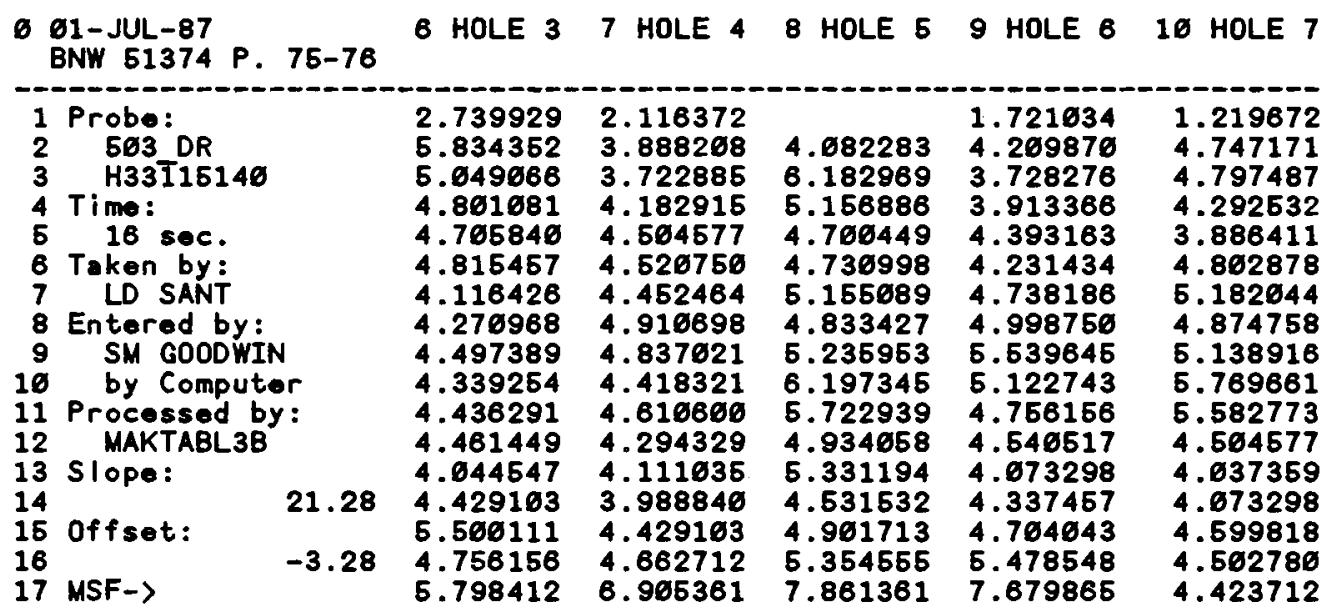

FIGURE A.4. Example of Processed Neutron Probe Data Stored Using RS/1 Format 
Neutron Probe Data for the Grass Site on May 20, 1987

$\emptyset$ 01-JUL-87 11 HOLE 8 12 HOLE 913 HOLE 1614 HOLE 11 15 HOLE 12 BNW 51374 P. 75-76

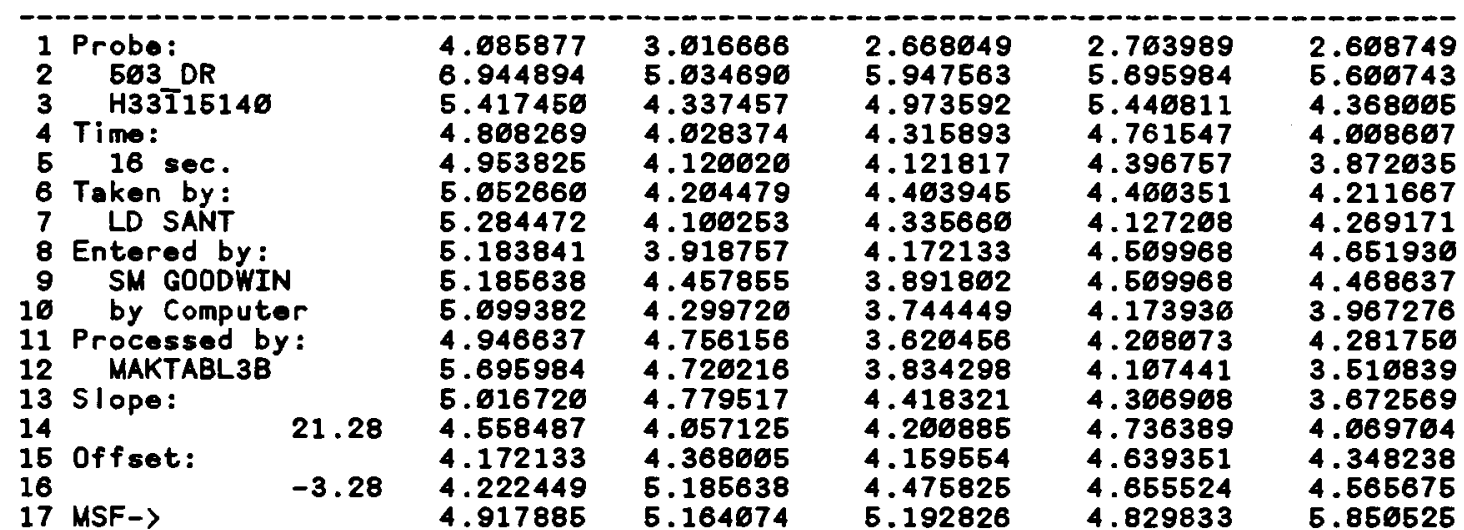

\section{1-JUL-87}

16 HOLE $13 \quad 17$ HOLE $14 \quad 18$ HOLE 15

19 HOLE $16 \quad 20$ HOLE 17 BNW 51374 P. 75-76

\begin{tabular}{|c|c|c|c|c|c|c|c|}
\hline $\begin{array}{ll}1 & f \\
2 & \\
3 \\
4 \\
5 \\
6 \\
6 \\
7 \\
8 \\
9 \\
9 \\
0 \\
1 \\
2 \\
2\end{array}$ & \multicolumn{2}{|c|}{$\begin{array}{l}\text { Probe: } \\
5 \emptyset 3 \text { DR } \\
\text { H33T115140 } \\
\text { Time: } \\
16 \text { sec. } \\
\text { Taken by: } \\
\text { LD SANT } \\
\text { Entered by: } \\
\text { SM GOODWIN } \\
\text { by Computer } \\
\text { Processed by: } \\
\text { MAKTABL3B }\end{array}$} & $\begin{array}{l}2.977132 \\
5.228765 \\
4.495592 \\
4.375193 \\
3.898996 \\
4.646953 \\
4.626577 \\
4.760765 \\
4.968261 \\
4.583646 \\
4.767953 \\
5.695788 \\
4.691464 \\
4.617156 \\
4.844269 \\
4.881946 \\
5.997879\end{array}$ & $\begin{array}{l}3.354561 \\
5.994285 \\
5.359946 \\
4.792696 \\
4.687870 \\
4.574660 \\
4.252998 \\
4.297923 \\
4.233231 \\
4.366908 \\
4.781314 \\
5.291660 \\
3.969673 \\
4.663216 \\
4.475825 \\
4.563878 \\
5.243141\end{array}$ & $\begin{array}{l}3.486290 \\
6.276413 \\
4.844269 \\
4.218855 \\
4.269171 \\
4.141584 \\
4.285344 \\
4.244613 \\
4.961713 \\
5.295254 \\
4.736389 \\
4.118223 \\
4.882283 \\
4.162656 \\
4.474628 \\
4.229637 \\
5.886863\end{array}$ & $\begin{array}{l}2.636869 \\
5.431826 \\
4.452464 \\
4.068697 \\
3.736673 \\
3.778591 \\
3.722885 \\
3.845686 \\
4.247607 \\
4.653531 \\
4.648141 \\
4.348238 \\
4.229637 \\
4.685877 \\
4.665613 \\
4.461449 \\
5.261811\end{array}$ & $\begin{array}{l}3.638426 \\
6.835616 \\
4.917885 \\
4.896659 \\
4.211667 \\
4.294329 \\
4.118223 \\
4.616464 \\
4.289876 \\
4.873298 \\
4.279953 \\
5.849666 \\
4.384178 \\
4.152366 \\
4.732795 \\
4.662712 \\
5.618081\end{array}$ \\
\hline
\end{tabular}

FIGURE A.4. (contd) 
Neutron Probe Data for the Grass Site on May 20, 1987

$61-J U L-87$

36 STANDARD DEV 31 MOISTURE $(\mathrm{cm})$

32 ROWMEAN

BNW 51374 P. $75-76$ GRASS PLOT GRASS PLOT ROTOTILLED

1 Probe:
2 563 DR
3 H33115140
4 Time:
5 16 sec.
6 Taken by:
7 LD SANT
8 Entered by:
9 SM GOODWIN
19 by Computer
11 Processed by:
12 MAKTABL3B
13 Slope:
14 Offset: 21.28
15 Off set:
16
17 MSF->

0.716877
0.738794
0.608993
0.457499
0.431463
0.358726
0.485979
0.398414
0.464216
0.715761
0.588576
0.668948
0.564976
0.258856
0.398559
0.325416
.778644

\begin{tabular}{|c|c|}
\hline $\begin{array}{l}0.444642 \\
\emptyset .861698 \\
0.762539 \\
0.671547 \\
0.652679 \\
0.66656 \emptyset \\
0.660136 \\
0.665482 \\
0.687277 \\
6.684625 \\
6.684941 \\
1.322873 \\
1.296888 \\
1.282846 \\
1.378668 \\
1.396224 \\
1.616466\end{array}$ & $\begin{array}{l}3.646186 \\
6.291987 \\
4.898718 \\
4.412936 \\
4.244613 \\
4.349436 \\
4.664611 \\
4.669361 \\
4.944241 \\
4.647166 \\
4.396767 \\
4.643544 \\
4.389569 \\
4.286542 \\
4.648336 \\
4.859184 \\
6.327927\end{array}$ \\
\hline
\end{tabular}

61-JUL-87
BNW 51374 P. 75-76 33 STANDARD DEV 34 MOISTURE (cm)
ROTOTILLED

1 Probe:

2 683 DR

3 H33I15140

4 Time:

516 soc.

6 Taken by:

8 Entered by:

9 SM GOODWIN

by Computer

rocessed by:

12 MAKTABL3B

1421.28

15 offset:

21.28

17 MSF->

$-3.28$

\begin{tabular}{|c|c|}
\hline $\begin{array}{l}2.166465 \\
2.771173 \\
1.415726 \\
0.519462 \\
0.299716 \\
0.381436 \\
0.523468 \\
0.376843 \\
0.667738 \\
0.594749 \\
0.624654 \\
.419543 \\
.0369334 \\
0.269846 \\
0.228868 \\
0.631653 \\
1.220846\end{array}$ & $\begin{array}{l}0.531927 \\
0.943798 \\
0.734868 \\
0.66194 \emptyset \\
0.636662 \\
0.652415 \\
0.696662 \\
0.766396 \\
0.741636 \\
0.682666 \\
6.659614 \\
1.393663 \\
1.316871 \\
1.285963 \\
1.394561 \\
1.457755 \\
1.898378\end{array}$ \\
\hline
\end{tabular}

FIGURE A.4. (contd) 


\section{Procedures for Automated Data Collection and Storage}

Most data collected at the BWTF and the Grass Site are automatically collected using CSI (Campbell Scientific, Inc., Logan, Utah) data loggers. The programs controlling data collection are generated and edited using CSI software that operates on the IBM PC/AT. The data logger program controls which sensors are interrogated, time interval, and date(s) of the measurement. An example of a program for a data logger and short descriptions of the software programs are given in this appendix. The data are output to a cassette tape recorder and transmitted daily via telephone and modem to the IBM PC/AT in PNL's laboratory. The data are sorted daily and then transmitted to the HSPA MicroVAX, where they are entered into RS/1. Data from key sensors are then plotted and the quality of the data inspected before it is added to the HSPA RS/1 data base.

These data sets include scale readings from the weighing lysimeters, rainfall, soil temperatures, ambient temperature, wind speed, solar radiation, and relative humidity, as described in Table A.1. The information collected at the BWTF from 1983 have been read into the RS/1 software and analyzed. Raw data files for 1983 to 1985 are stored on the user-mountable hard disk. Processed data are stored in RS/1 directories for each site. Within the directory for each site, data are organized according to calendar year. The file names of the RS/1 tables reflect where the data were collected, the calendar year, and whether the data are hourly or daily averages.

Micrometeorological data collected from the Grass Site since September 1986 are similarly transmitted by telephone and read into the RS/1 software on the HSPA MicroVAX.

Procedures for Incorporating Field and Laboratory Data

Several types of data (see Table A.1) are collected manually in the field or result from laboratory analyses:

- Drainage data are collected manually from the north and south weighing lysimeters and south caisson at the BWTF. These data are manually entered into RS/ 1 and processed using RS/1 procedures to obtain cumulative values of drainage during the monitoring period. 
- Soil-water potential is measured in the field at the BWTF and at the Grass Site. These data are entered manually into RS/1 for analysis.

- Plant-water potential is measured in the field at the BWTF and at the Grass Site. These data are entered manually into RS/1 for analysis.

- Plant-water relations data measured in the field, estimates of canopy cover, and phenology observations for the Grass Site are entered and stored on the HSPA MicroVAX.

- Soil hydraulic conductivity data are manually entered and stored using RS/1 software.

- Data on particle size, density, and gravimetric moisture from laboratory analyses are also entered and stored in tables using RS/1 software.

\section{Procedures for Incorporating Hanford Site Meteorological Station Data}

Meteorological data of interest are obtained from the HMS. Precipitation data are read into RS/1 software from these files and stored as tables for comparison with micrometeorological data collected at the field study sites.

\section{Code Documentation and Entry into Archive}

UNSAT-H Version 1.0 (Fayer, Gee, and Jones 1986) was archived on tape and on a user-mountable hard disk as follows: 1) on a 3/4-in. 1600 BPS VAX tape in a locked cabinet in PNL's Sigma $V$ Building computer room, 2) on a 3/4-in. BPI VAX tape in M. J. Fayer's office (room 2607, Sigma V, Pacific Northwest Laboratory, Richland, Washington), 3) on a user-mountable hard disk labeled 'TARDIS' in the Sigma $V$ computer room, and 4) as a working copy on the PNL ZVAX.

Version 1.0 of UNSAT-H was updated in 1987 to include additional options for computing functions affecting hydraulic conductivity and recompiled and archived as Version 1.1 in accordance with QA procedures. Version 2.0 will 
be completed and available by 0ctober 1988. UNSAT2 (Davis and Neuman 1983) has been used on an interim basis for protective barrier analysis (Fayer et a1. 1985).

\section{IBM PC-COMPATIBLE SOFTWARE FOR ACCESSING DATA LOGGERS}

Automated collection of field data is accomplished using CSI data loggers. Programs entered into the data loggers for data collection and processing are documented. An example of a program generated for the BWTF site using the CSI software, EDLOG, is given in Figure A.5 (page A.16). The EDLOG program operates on the IBM PC/AT and allows us to label and document sensors on the program itself. Other CSI software is used with IBM PCs to automatically access data from field sites over telephone lines or radio links, to monitor data from the sensors in real time, or to download new programs to the data logger or upload an old program to check for validity. CSI's PC205 telecommunications software includes:

- TELECOM(a).--interrogates CSI data loggers and retrieves and stores the data. The program can be used in either an attended or unattended mode.

- TERM(a)--works as a terminal emulator to establish communications with a data logger. The program is used to monitor the data from the data logger in real time, or to download, retrieve, or alter data-logger programs.

- $P C 206(a)$--software supports the telecommunications software and allows development and editing of data-logger programs through use of the EDLOG program.

(a) TELECOM, TERM, and PC206 are tradenames of Campbe11 Scientific, Inc., Logan, Utah. 


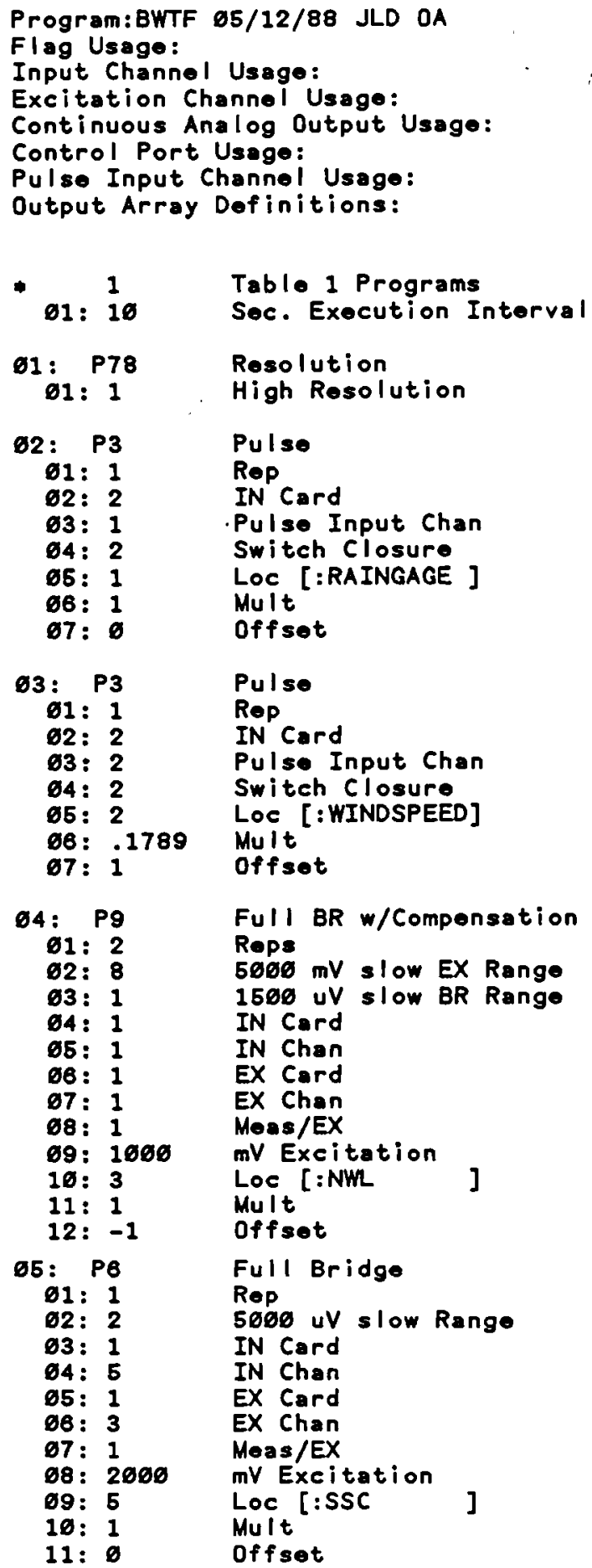

Full BR w/Compensation

Repa

$5800 \mathrm{mV}$ s low EX Range

1500 UV slow BR Range

IN Card

IN Chan

EX Card

EX Chan

Meas/EX

$m V$ Excitation

Loc $[:$ NWL

Mu It

of fset

Full Bridge

Rep

5008 uV slow Range

IN Card

IN Chan

EX Card

EX Chan

Meas/EX

mV Excitation

Loc [:SSC

Mult

Offset

FIGURE A.5. Example of a Program Generated for the Buried Waste Test Facility Using the Campbell Scientific, Inc. Software 


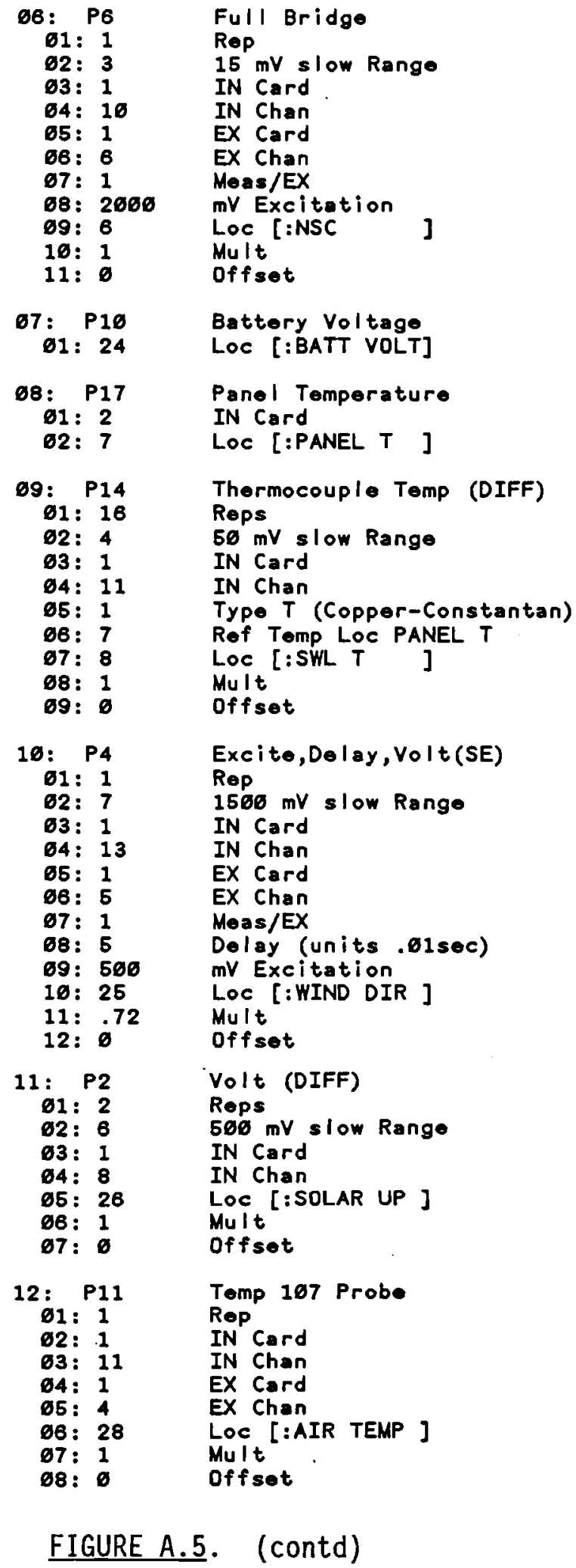




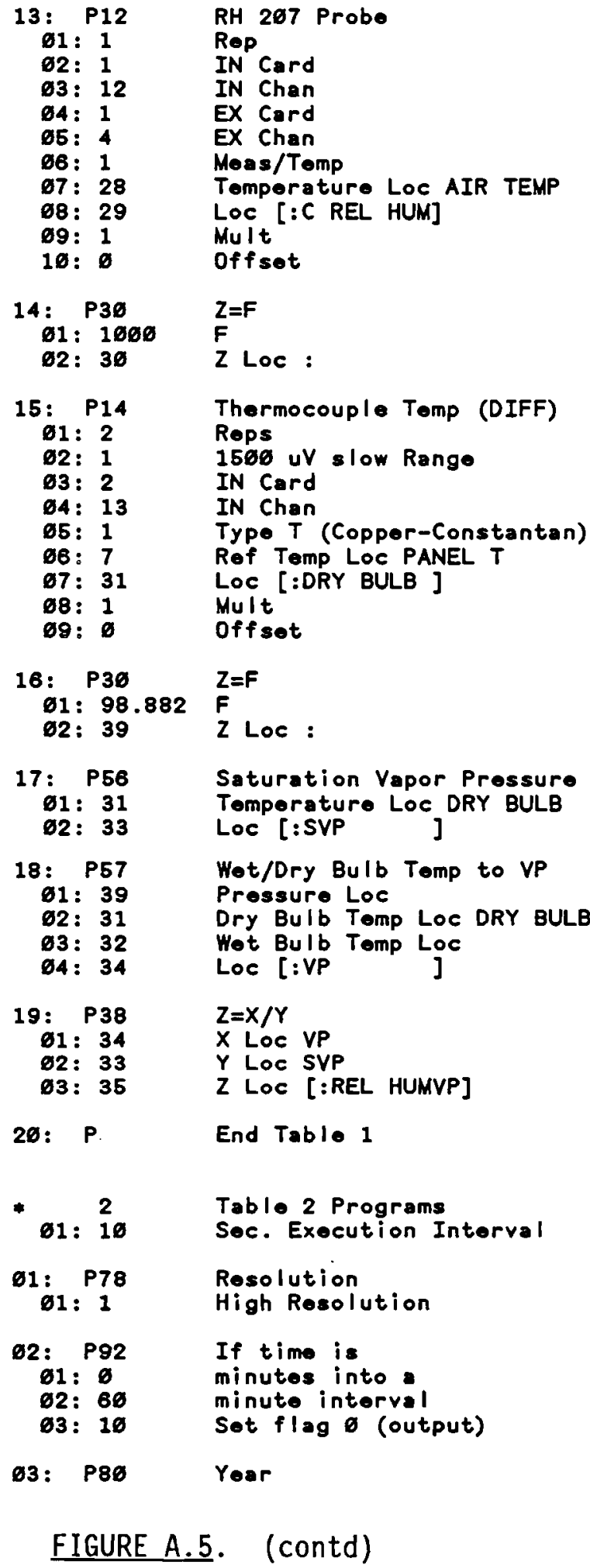

20: $P$

End Table 1

* $61: 2$

Table 2 Programs

1: $\quad$ P78 Soc. Execution Intorval

81: $1: 1$

Resolution

02: P92

ด1: $\theta$

62: 60 High Resolution

63: 10

If time is

minutes into.

minute interval

Sot flog (output)

03: $\quad$ P80

Yoar

FIGURE A.5. (contd) 


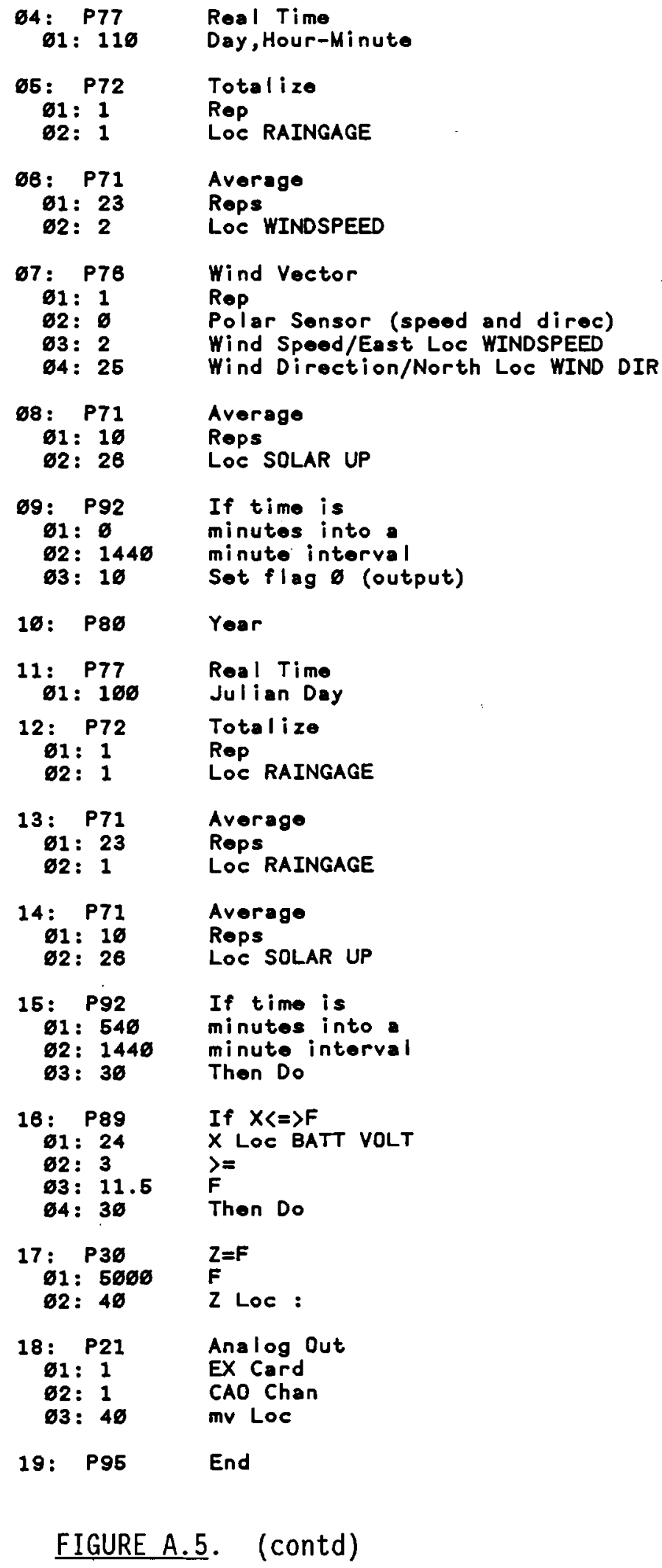

\begin{tabular}{|c|c|}
\hline $\begin{aligned} & 16: P 89 \\
& 01: 24 \\
& 02: 3 \\
& 03: 11.5 \\
& 04: 30\end{aligned}$ & $\begin{array}{l}\text { If } X \Leftrightarrow \Rightarrow F \\
X \text { LOC BATT VOLT } \\
\partial= \\
F \\
\text { Then Do }\end{array}$ \\
\hline $\begin{aligned} 17: & P 3 \emptyset \\
61: & 586 \theta \\
62: & 4 \varnothing\end{aligned}$ & $\begin{array}{l}Z=F \\
F \\
Z \text { Loc: }\end{array}$ \\
\hline $\begin{aligned} 18: & P 21 \\
61: & 1 \\
62: & 1 \\
93: & 40\end{aligned}$ & $\begin{array}{l}\text { Analog Out } \\
\text { EX Card } \\
\text { CAO Chan } \\
\text { mv Loc }\end{array}$ \\
\hline 19: & End \\
\hline
\end{tabular}

FIGURE A.5. (contd) 


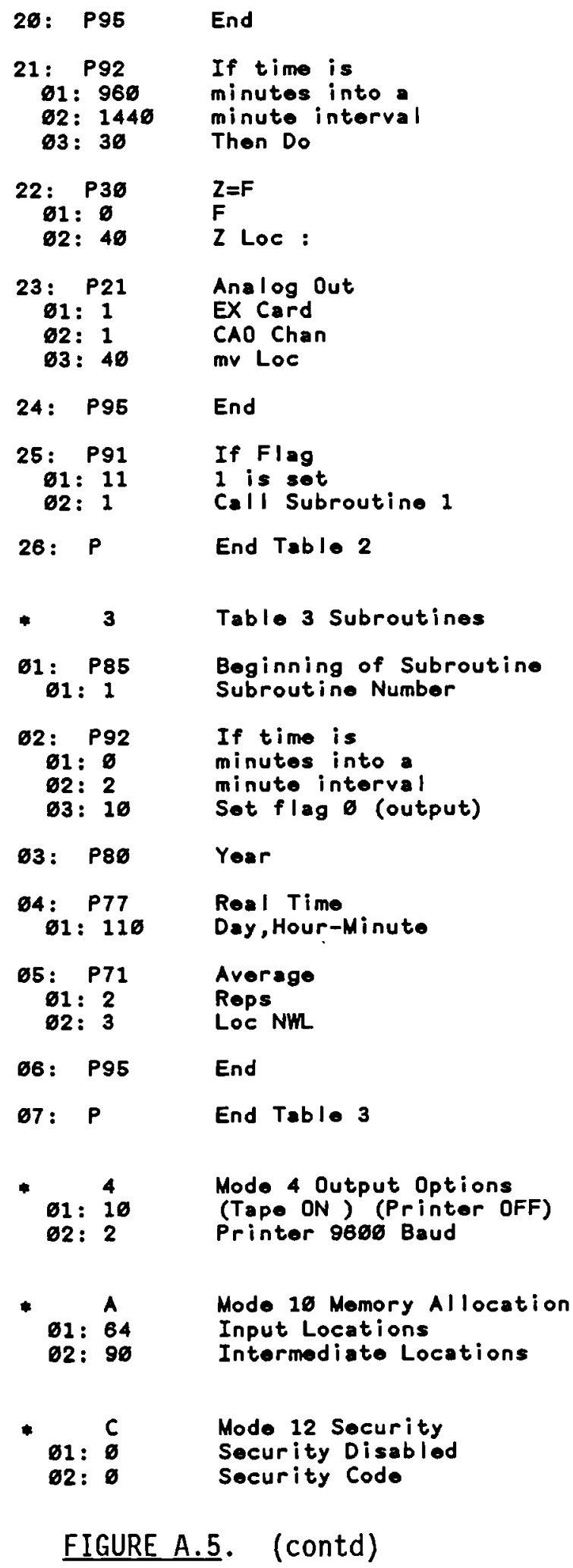

- 1 82: 90

Mode 18 Memory Allocation

Input Locations

Intermediate Locations

* C Mode 12 Security

01: $\emptyset$ Security Disablod

02: 0 Security Code

FIGURE A.5. (contd) 


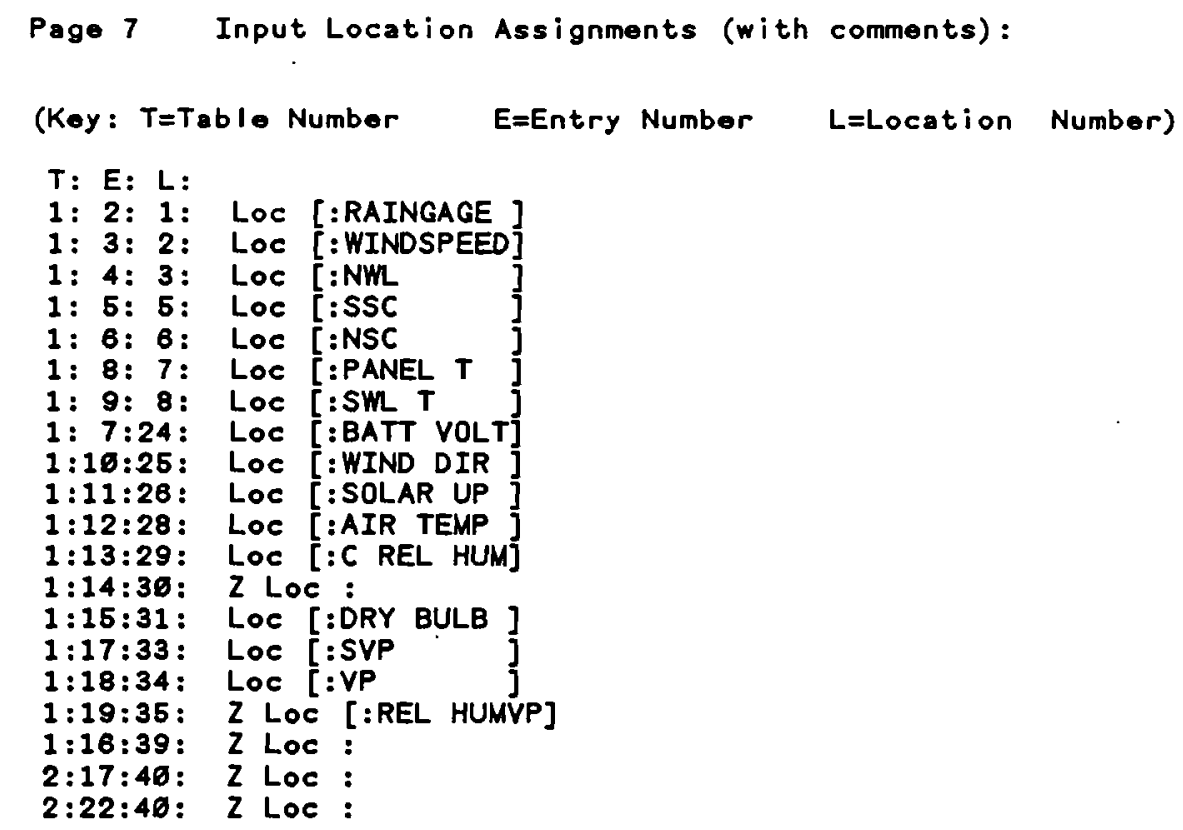

FIGURE A.5. (contd) 


\section{REFERENCES}

Cass, A., G. S. Campbe11, and T. L. Jones. 1981. Hydraulic and Thermal Properties of Soil Samples from the Buried Waste Test Facility. PNL-4015, Pacific Northwest Laboratory, Richland, Washington.

Davis, L. A., and S. P. Neuman. 1983. Documentation and User's Guide: UNSAT2-Variably Saturated Flow Model. NUREG/CR-3390, U.S. Nuclear Regulatory Commission, Washington, D.C.

Enfield, C. G., J. J. C. Hsieh, and A. W. Warrick. 1973. "Evaluation of Water Flux Above a Deep Water Table Using Thermocouple Psychrometers." Soil Science Soc. Am. Proc. 37:968-970.

Fayer, M. J., G. W. Gee, and T. L. Jones. 1986. UNSAT-H Version 1.0: Unsaturated Flow Code Documentation and Applications for the Hanford Site. PNL-5899, Pacific Northwest Laboratory, Richland, Washington.

Fayer, M. J., W. Conbere, P. R. Heller, and G. W. Gee. 1985. Model Assessment of Protective Barrier Designs. PNL-5604, Pacific Northwest Laboratory, Richland, Washington.

Gee, G. W., A. C. Campbe11, P. J. Wierenga, and T. L. Jones. 1981. Unsaturated Moisture and Radionuclide Transport. PNL-3616, Pacific Northwest Laboratory, Richland, Washington.

Gee, G. W., and A. C. Campbe11. 1980. Monitoring and Physical Characterization of Unsaturated Zone Transport: Laboratory Analysis. PNL-3304, Pacific Northwest Laboratory, Richland, Washington.

Gee, G. W., and R. R. Kirkham. 1984. Arid Site Water Balance: Evapotranspiration Modeling and Measurements. PNL-5177, Pacific Northwest Laboratory, Richland, Washington.

Heller, P. R., G.W. Gee, and D. A. Myers. 1985. Moisture and Textural Variations in Unsaturated Soils/Sediments Near the Hanford Wye Barricade. PNL-5377, Pacific Northwest Laboratory, Richland, Washington.

Hsieh, J. J. C., and C. G. Enfield. 1974. "Steady-State Method of Measuring Unsaturated Hydraulic Conductivity." Comm. in Soil Science and Plant Analysis 5:123-129.

Hsieh, J. J. C., L. E. Browne11, and A. E. Reisenauer. 1973. Lysimeter Experiment, Description and Progress Report on Neutron Measurements. BNWL-1711, Pacific Northwest Laboratory, Richland, Washington.

Sisson, J. B., and A. H. Lu. 1984. Field Calibration of Computer Models for Application to Buried Liquid Discharges: A Status Report. RHO-ST-46, Rockwel1 Hanford Operations, Richland, Washington. 
-

APPENDIX B

PRECIPITATION DATA

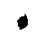


TABLE B.1. Precipitation Data from the Hanford Meteorological Station from January 1986 to JuTy 1988

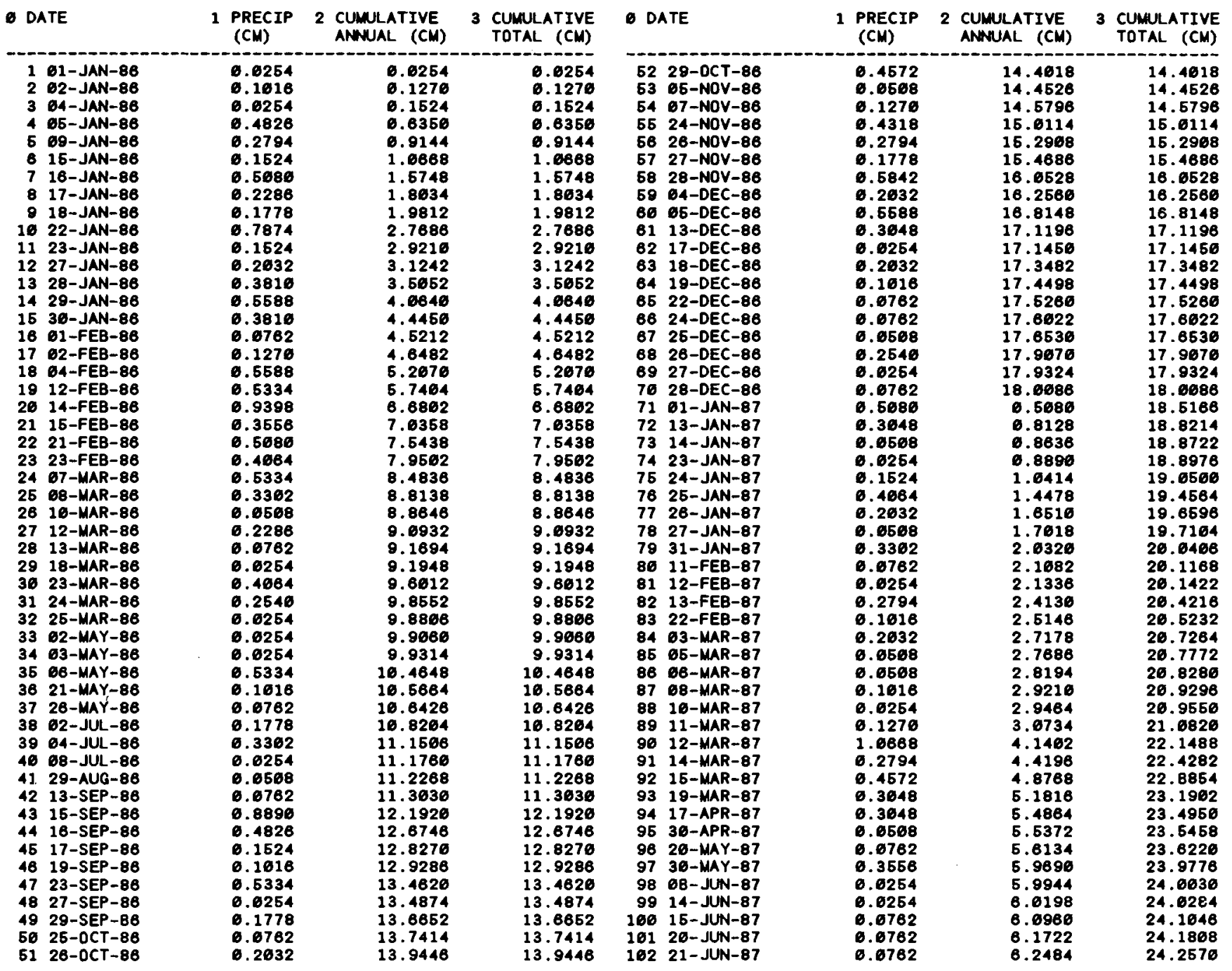


IABLE B.I (contd)

$\infty$

iv 1 PRECIP 2 CUMULATIVE 3 CUMULATIVE

- date 0.4608

7.6886

163 62-JUL-87

164 89-JUL-87

166 18-JUL-87

167 13-AUG-87

24-AUG-87

116 26-SEP-87

111 81-NOV-87
112 11-NOV-87

113 12-NOV-87

114 13-NOV-8

$115 \quad 36-N O V-87$

117 62-DEC-87

118 E3-DEC-87

119 64-DEC-87

121 BO-DEC-87

$\begin{array}{ll}122 & 69-D E C-87 \\ 123 & 15-D E C-87\end{array}$

124 16-DEC-87

125 28-DEC-87

126 B4-JAN-8B

127 67-JAN-88

129 69-JAN-88

18-JAN-88

131 14-JAN-8B

133 G4-MAR-88

134 BO-MAR-88

138 22-MAR-8B

137 28-MAR-88

138 29-MAR-8B

139 62-APR-88

146 E3-APR-8B

141 17-APR-88

142 19-APR-88

$14320-A P R-8 B$
144 22-APR-88

145 27-APR-8B

146 28-APR-8B

147 30-APR-8B

149 68-MAY-8B

$15018-M A Y-8 B$

151 27-MAY-88

152 28-MAY-8B
153 B1-JUN-88

6.1524

0.6858

0.1278

0.3648
0.1618

6.0254

.0508

7.2136
7.5184

7.6200

7.6454

7.6962

$0.0254 \quad 7.7216$

$0.4572 \quad 8.1788$

6508

8.2296

.0508

. 2546

8.2804

8.2794

8.8604
8.3648

.0508

6.1778

8.7378

9.0178

0.0774

16.8330

10.2108

16.5918

11.9888

1.3978

6.2288

12.2174

$\begin{array}{ll}6.4826 & 12.7696 \\ 6.2632 & 12.9632 \\ 8.0568 & 8568\end{array}$

6.0588

6.6588
8.3362

0.3362
6.1778

. .1016

.4318

.6096

0.4864

0.1778
0.0254

0.1524

0.0254

8.4828

0.0782
0.2286

0.2286

6.0254

6.6568

6. 0144

6.0782

0.2632

. 1778

0.0254

1.2192

0.1524
0.8254

0.0254

0.0508

0.0254

6.7112
6.8588

1.0160

1.1938

1.2192

1.3716

1.3970

1.8796

2.1844

2. 2698

2.2352

2.2866

3. 2004

3.2786

3.4798

3.6576

3.6830

4.9622
5.0546

5.6546
5.8800
5. 1054

5.1654

5.1816

5.8928
5.9436

24.4894

5. 6052

25.5270

25.0288

25.8546

25.7648

25.7362

26.1874

28.2896

政.

27.8258

27.6888

27.9988

28.0418

28. 2194

28.6084

28.8974

36. 7888

39.

9826

31.6134

31.3436

31.5214

32.2056

32.1316

32.2834

32.3088

32. 8878

33.6962

33.1216

3..1978

.

34.3918

34.589

34.5948

35.9884

35.9918

38.0172

36.6886

36.6934

36.8648
36.8554

\begin{tabular}{|c|c|c|c|}
\hline D DATE & $\begin{array}{l}1 \text { PRECIP } \\
(\mathrm{CM})\end{array}$ & 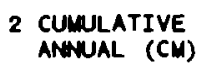 & $\begin{array}{l}3 \text { CUMULATIVE } \\
\text { TOTAL (CM) }\end{array}$ \\
\hline $\begin{array}{ll}154 & 62-J U N-88 \\
155 & 64-J U N-88 \\
156 & 65-J U N-88 \\
157 & 13-J U L-88\end{array}$ & $\begin{array}{l}0.6254 \\
0.6254 \\
0.1778 \\
0.3362\end{array}$ & $\begin{array}{l}5.9696 \\
5.9944 \\
6.1722 \\
6.5624\end{array}$ & $\begin{array}{l}36.8898 \\
36.9662 \\
37.6840 \\
37.4142\end{array}$ \\
\hline
\end{tabular}


TABLE B.2. Precipitation Data for the Buried Waste Test Facility from January 1986 to July 1988

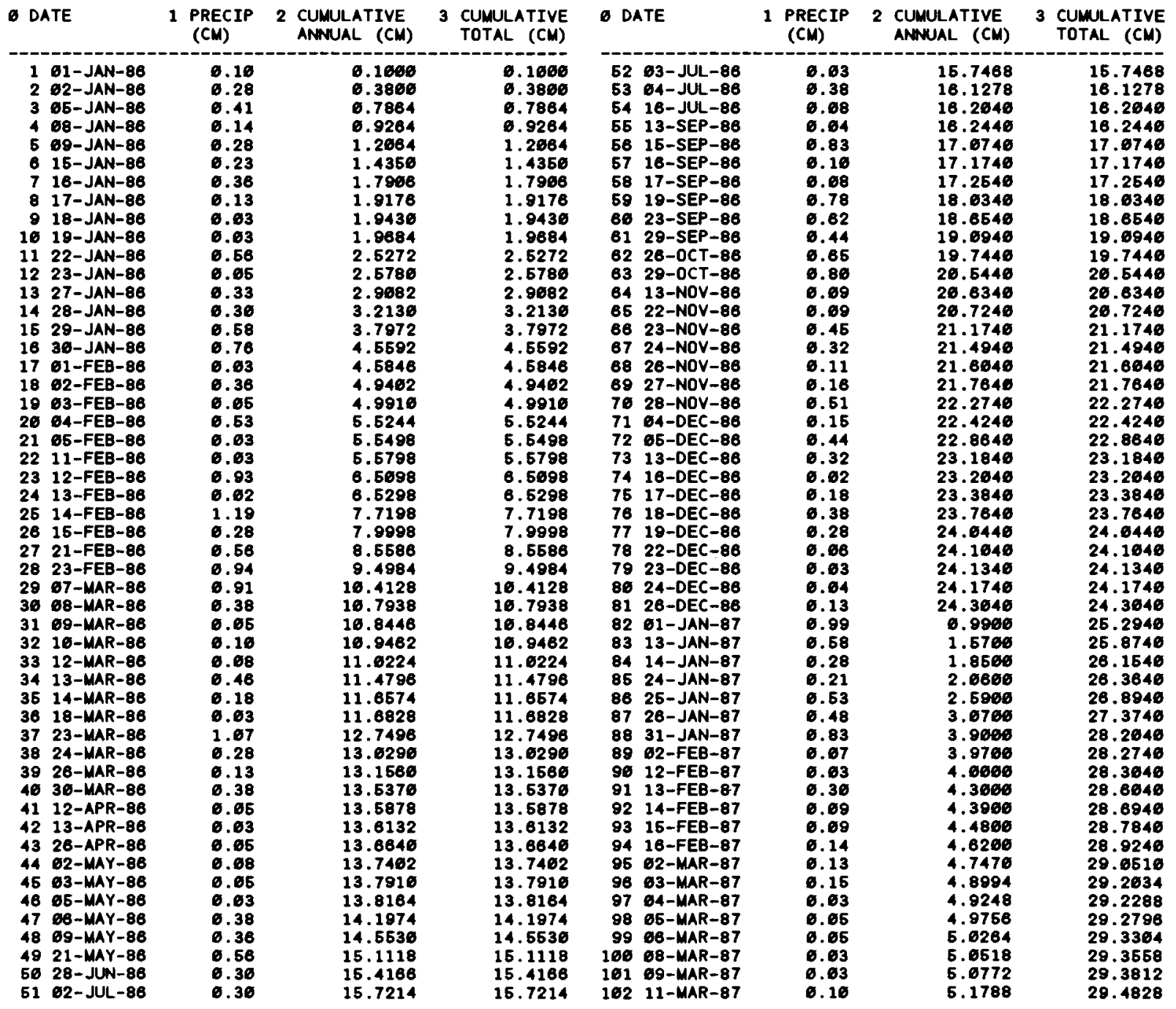


IABLE B.2. (contd)

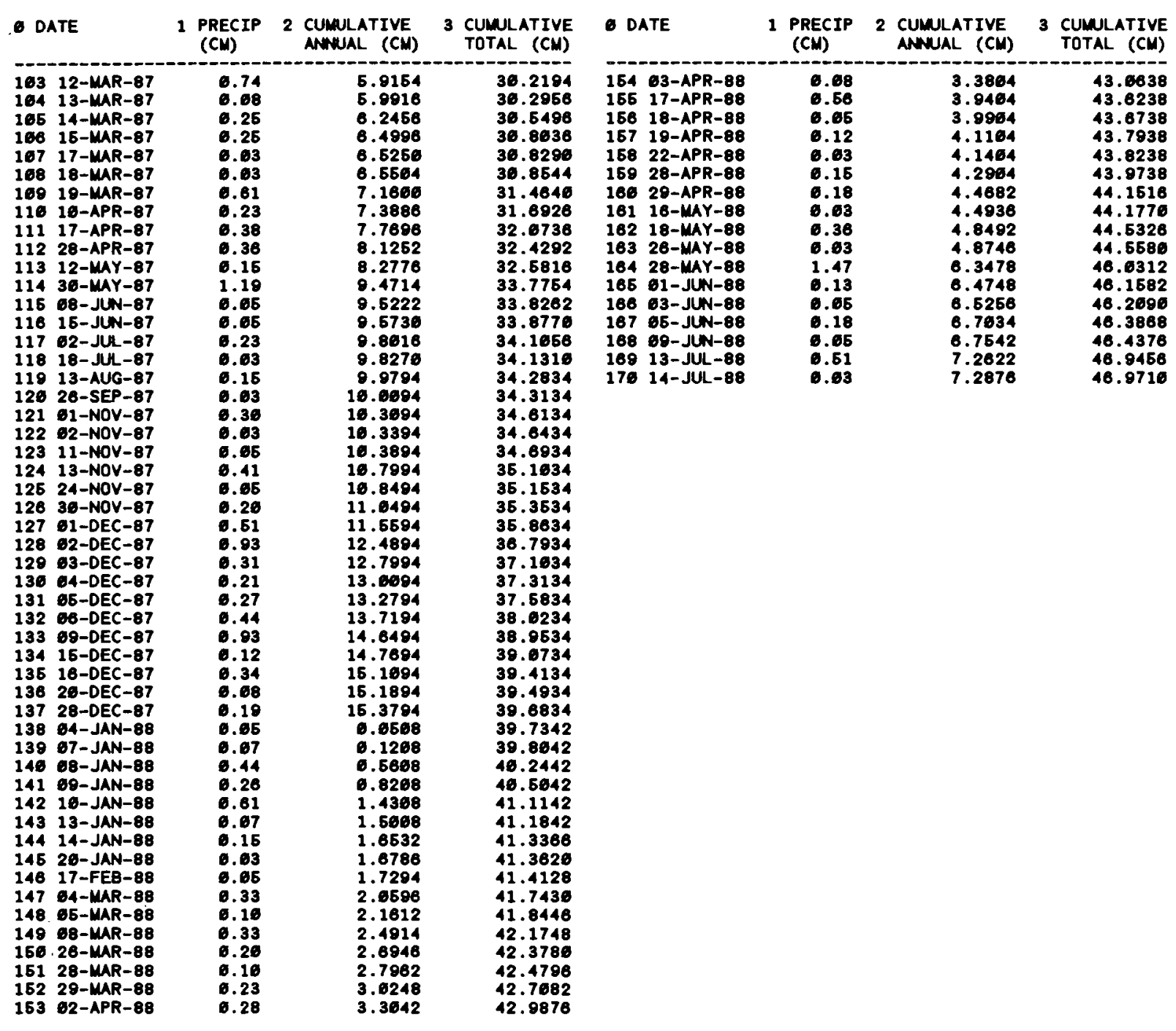


APPENDIX C

WATER STORAGE PROCEDURES AND DATA 
Technical Procedure No. HSPA ?

TITLE: MEASUREMENT OF SOIL MOISTURE IJSING THE NEUTRON PROBE

\subsection{APPLICABILITY}

This procedure describes the use of the 503-DR Hydroprobe Neutron Depth moisture Gauge in measuring soil moisture in the field. The 503DR measures subsurface moisture in soil and other materials by using a probe containing a source of high energy neutrons and a slow (thermal) neutron detector. Impact of the fast neutrons with hydrogen present in the water in the soil slows some of the neutrons and deflects them back for detection. The measurement of the number of slow neutrons detected is displayed directly on a digital readout unit attached to the source shield assembly. The digital readout unit operates on NICAD batteries and should be charged before being used. For further information concerning the 503DR, see the operators manual on file in the field lab, Room 1519, Sigma V.

\subsection{DEFINITIONS}

None. For further technical information, see the operators manual in Room 1519 of Sigma $V$.

\subsection{RESPONSIBLE STAFF}

Neutron Probe Operator.

\begin{tabular}{|c|c|c|c|}
\hline Concurrence & Date $4 / 2$ & Roproved & $5 / 9 / 8 \varnothing$ \\
\hline $\begin{array}{l}\text { Prepared py } \\
\mathrm{JL} \text { Downs }\end{array}$ & $\begin{array}{l}\text { Dace } \\
4 / 28\end{array}$ & $\begin{array}{l}\text { QAO Concurrence } \\
\text { CR Len }\end{array}$ & $5 / 6 / 88$ \\
\hline $\begin{array}{c}\text { Proceghire Yo. } \\
\text { HSPA } 1\end{array}$ & $\begin{array}{c}\text { Reyizion No. } \\
0\end{array}$ & $\begin{array}{l}9 \text { May } 1988 \\
9 \text { Mfective Dase }\end{array}$ & $\begin{array}{r}\text { Page } \\
1\end{array}$ \\
\hline
\end{tabular}

FIGURE C.1. Technical Procedure for Soil Moisture Measurement
Using the Neutron Probe 


\subsection{PROCEDURE}

\subsection{Equipment and Training}

- 503-DR Hydroprobe (serial no. 53115140), Neutron Depth Moisture Gauge or equivalent

- Project notebook (Laboratory Record 8ook, LRB)

- Appropriate cable for the site to be measured (see LRB)

- Radiation Safety Trainíng

\subsection{Setting the Format, Time, and Units}

The FORMAT key allows the user to specify the number of wells to be monitored and the number of depths to be measured at each well. Whenever the format is changed, any data on the unit are lost. Therefore, before setting the format, check to make sure that any data taken previously has been 'dumped' or telecommunicated from the digital readout unit to a floppy disk.

The steps to set the format are as follows:

\subsubsection{Press the FORMAT button on the readout unit. Press STEP until} Depth--appears. Key in the number of depths that will be measured for each well and press the ENTER button.

4.2.2 The readout unit wil! then read SET FMT? Press ENTER to set the format.

Set the counting time on the readout unit by first pressing the TIME key. Next press the STEP key until the appropriate time shows on the screen and then press the ENTER button.

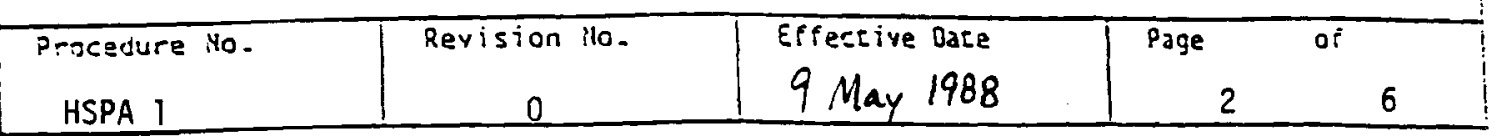

FIGURE C.1. (contd) 


\begin{tabular}{|c|c|c|}
\hline Location & Time & Depths \\
\hline $\begin{array}{l}300 \text { Grass Site } \\
\text { BWTF Lysimeters } \\
\text { 200E Lysimeter } \\
\text { CWLA } \\
\text { Grout Lysimeters }\end{array}$ & $\begin{array}{l}16 s \\
16 s \\
16 s \\
32 s \\
32 s\end{array}$ & $\begin{array}{l}17 \\
25 \\
38 \\
20 \\
28\end{array}$ \\
\hline
\end{tabular}

The units are set in the same manner as the time. First press the UNIT key on the readout unit. Then press the STEP key until the correct units are displayed (i.e., COUNT LN) and press the ENTER key.

\subsection{Mean Standard Count}

The neutron probe must be tested in a reference standard at the beginning and end of each day of use. The reference standard may be any invariable medium that will absorb energy from fast neutrons to allow them to react with the detector while they are within its range. The neutron probe shield is used as a standard. Thirty-two measurements must be made in the reference standard. The mean value of the thirty-two measurements is the mean standard count.

4.3.1 Attach the digital readout unit to the hydroprobe and connect the cable from the probe to the readout unit.

4.3.2 Place the probe in the proper position in the indentation on the probe case. Take 32 readings. The 503-DR probe does this automatically:

4.3.2a Press STD on the readout unit. The unit will display the last standard count taken. Press STEP to display the previous chi value. Press STEP again to display the previous mean standard count.

\begin{tabular}{|c|c|c|cc|}
\hline $\begin{array}{c}\text { Procedure Mo- } \\
\text { HSPA 1 }\end{array}$ & Revision llo. & $\begin{array}{c}\text { Efertive Date } \\
9 \text { Mage } 1988\end{array}$ & 3 & 6 \\
\hline
\end{tabular}

FIGURE C.1. (contd) 
4.3.2b Press STO again; the readout unit will inquire, NEW STD? Press ENTER; the probe will then begin taking 32 consecutive 8-second counts to compute the mean standard count. Stand at least 10 feet from the probe during this time to minimize any effects on the mean standard count. When the probe is finished record the mean standard count, the previous mean standard count, the Chi value, and the serial number of the probe in the LRB.

4.3.3 Evaluate the function of the neutron probe by computing the Chi statistic, R. This calculation is performed automatically by the 503-DR probe if the STD option is used. (If the mean standard count is determined manually, the $R$ value can be calculated using the equations at the end of this step.)

If $0.75 \leq R \leq 1.25$, the probe is working properly.

If $R>1.25$, the detector is not counting some of the neutrons.

If $R<0.75$, the detector is counting pulses other than neutrons.

If the Chi value (R) is too high or too low, repeat the test up to 4 times. If the average of the 4 tests is outside the range 0.75 to 1.25 , return the probe electronics to the factory for repair.

Equations for manualiy calculating R:

Mean standard count (MSC) $=\frac{\sum_{j=1}^{n} X_{j}}{n}$

where $n$ is the total number of readings and $X$ represents an individual reading

\begin{tabular}{|c|c|c|cc|}
\hline $\begin{array}{c}\text { Procedure to. } \\
\text { HSPA 1 }\end{array}$ & Revision ilo. & $\begin{array}{c}\text { Effecrive Oate } \\
9 \text { May } 1988\end{array}$ & 4 & 6 \\
\hline
\end{tabular}

FIGURE C.1. (contd) 


$$
\text { Standard Deviation }(S)=\left[\frac{\sum_{i=1}^{n}\left(X_{i}-M S C\right)^{2}}{n-1}\right]^{1 / 2}
$$

$$
\text { Chi Statistic }(R)=S / M S C^{1 / 2}
$$

NOTES:

The range 0.75 tc 1.25 is based on a sample size of 32 and a probability interval of 0.95 . The range should be recalculated if $a^{\text {a }}$ different sample size is used.

The 503-DR displays ' $S$ ' with the current Standard Count, ' $P$ ' with the previous Standard Count and 'Chi' with the ratio, R.

The DR automatically adjusts all readings to a 16 -second reading equivalent. Even the automatic calibration makes this adjustment after taking 32 eight-second readings and computing the Chi value. Therefore, if probe calibration is done manually, select the 16 -second time interval because any other time interval will yield an incorrect Chi value.

\subsection{Measurement}

4.4.1 Place the probe on top of the access port. Record in the LRB the time, access port identification, and the depths to be measured.

4.4.2 Lower the probe to the deepest depth and secure the stop on the top of the probe.

4.4.3 Press LOG on the keypad on the readout unit.

4.4.4 Key in the appropriate I.D. number and press ENTER. (The I.D. number consists of a location code and the well number; for example, 991 where 99 is the location code and 1 is the well number.)

\begin{tabular}{|c|c|c|cc|}
\hline $\begin{array}{c}\text { Procedure Mo- } \\
\text { HSPA 1 }\end{array}$ & Revision ilo- & $\begin{array}{c}\text { Efective Oate } \\
9 \text { Mage }\end{array}$ & of \\
\hline
\end{tabular}

FIGURE C.1. (contd) 
Location codes:

$$
\begin{array}{cc}
\text { BhiTF } & 55 \\
300 N \text { Grass site } & 99 \\
\text { CWLA } & 66 \\
200 \text { East Lysimeter } & 22 \\
\text { (Grout Access tubes are not logged and stored) }
\end{array}
$$

4.4.5 STEP through the $K$ Data query. The unit will then read TAKE \#, where the number refers to the deepest depth that you set in the FORMAT statement.

4.4.6 Press START. The probe will then take the count and display the value on the readout unit.

4.4.7 Record the yalue in the laboratory notebook alongside the corresponding depth. Press ENTER to store the value in the digital readout unit. The readout unit will then read TAKE \#, indicating the probe is ready to read the next depth:

4.4.8 Move the cable to the next depth to be measured, and repeat steps 6 and 7 untii al I measurements for a well are logged. After entering the value for DEPTH 1 , the readout unit will query DATA OK?

4.4.9 If data were taken satisfactorily, press ENTER and go on to log the next well. If a mistake was made in taking the readings, press the STEP key to return to that depth and retake that count. Then press STEP to reach the DATA OK? query and press ENTER.

4.4.10 When data collection is completed, bring the digital readout unit to Sigma V/1519. Download the data to the HSPA MicroVAX per instructions from the data base steward.

\begin{tabular}{|c|c|c|cc|}
\hline $\begin{array}{c}\text { Procedure Ho. } \\
\text { HSPA 1 }\end{array}$ & $\begin{array}{c}\text { Refision ilo. } \\
9 \text { Mage May } 1988\end{array}$ & 6 & 6 \\
\hline
\end{tabular}

FIGURE C.1. (contd) 


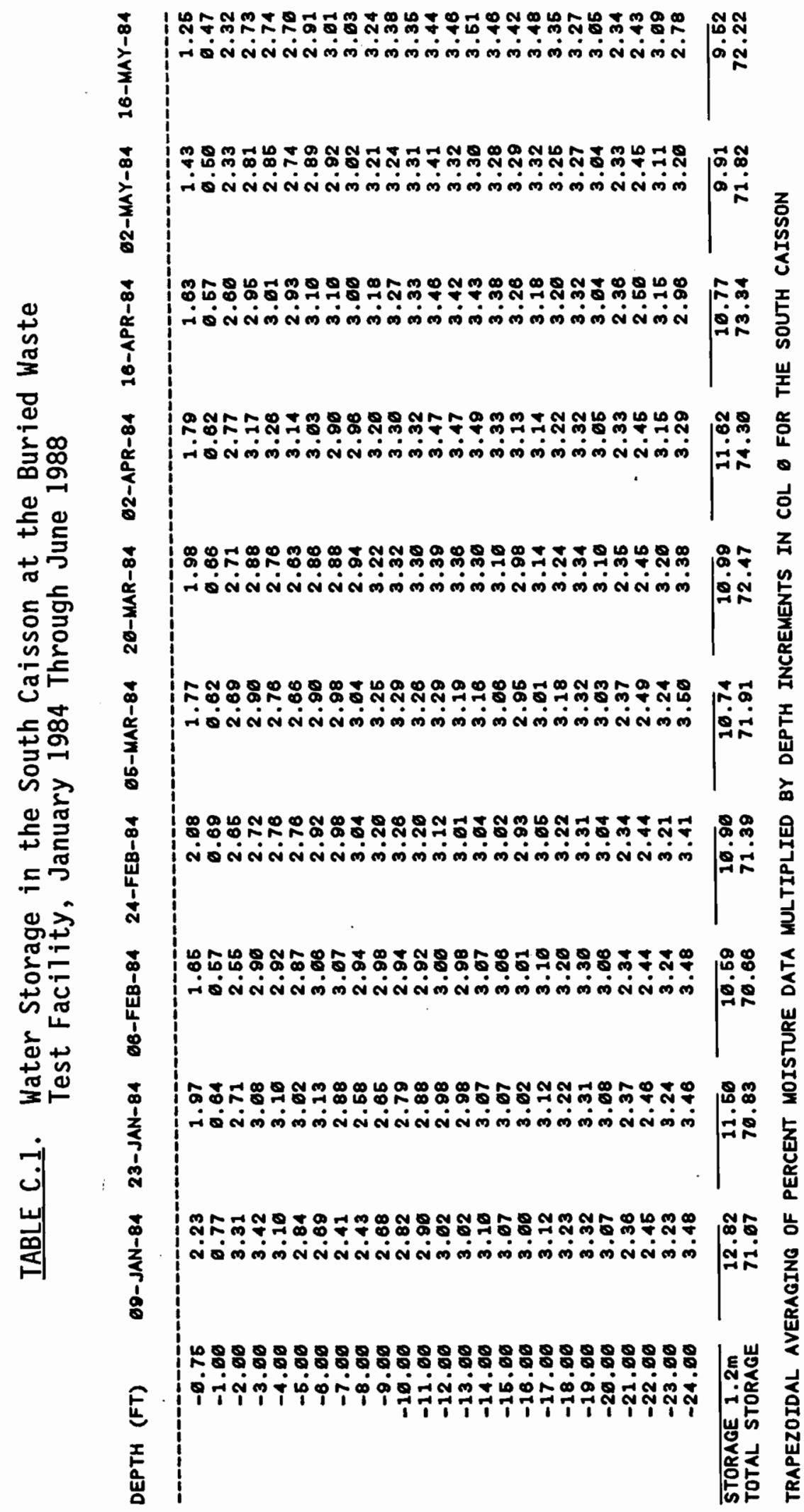

C. 7 


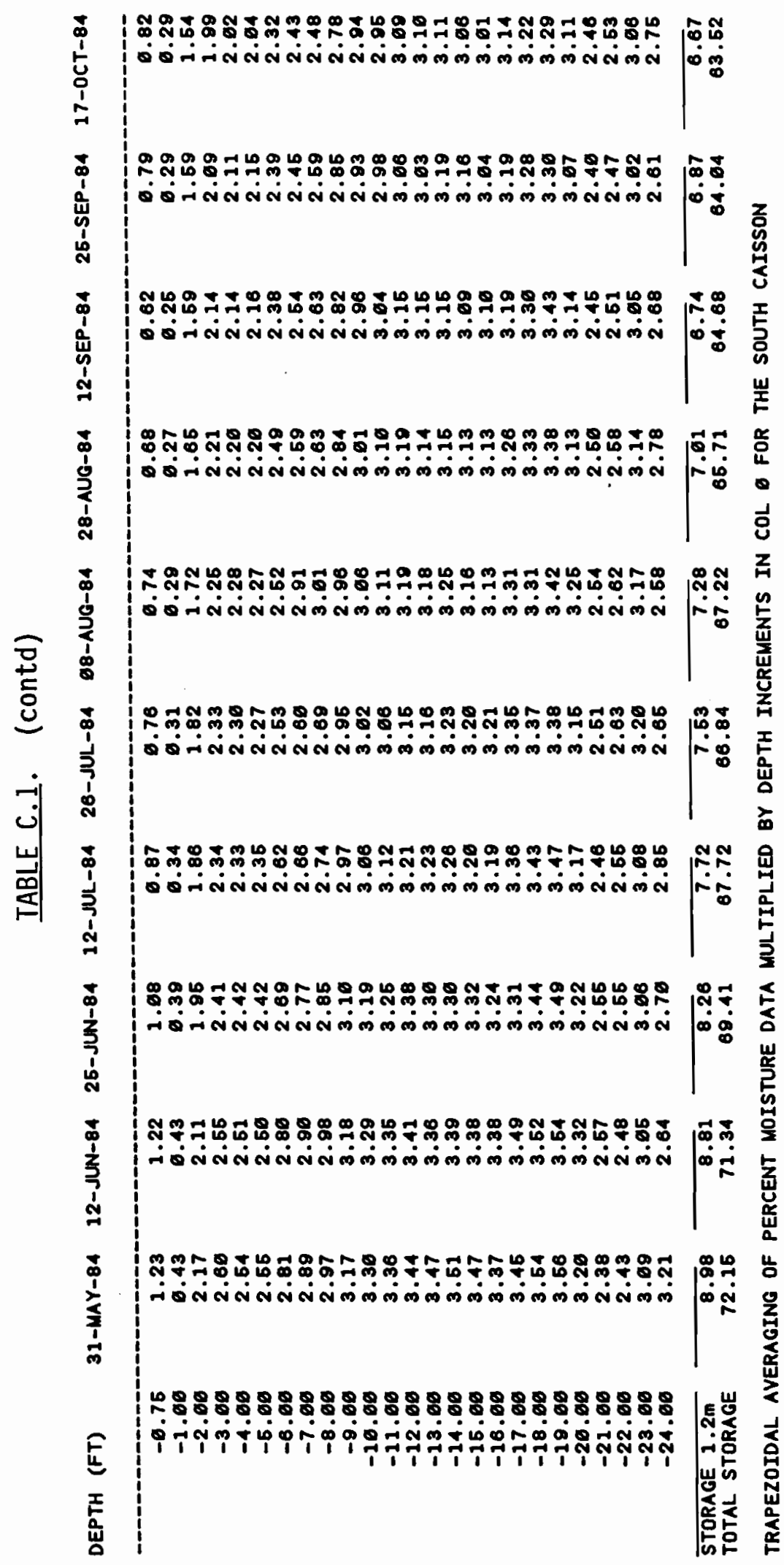

C. 8 


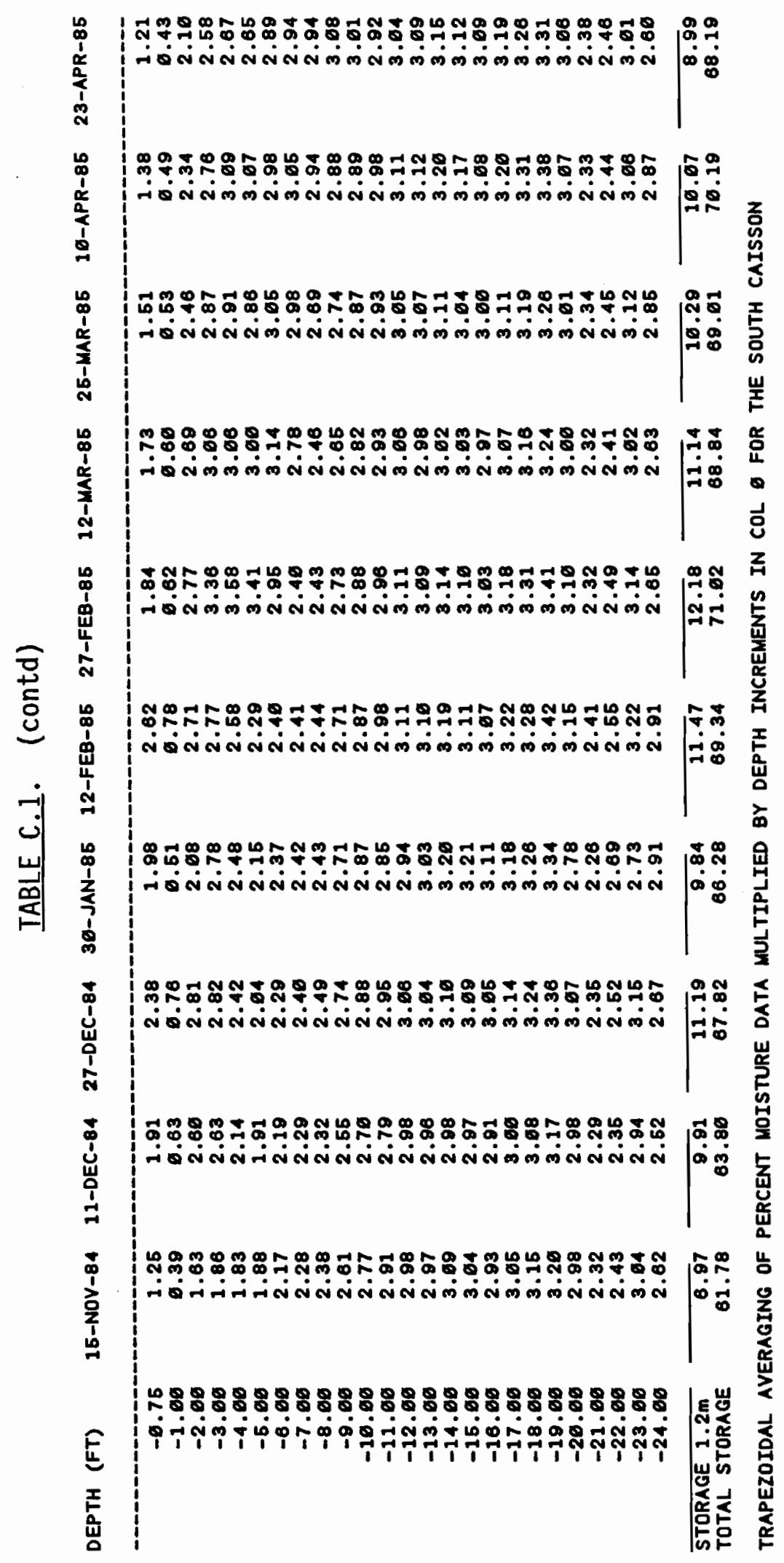

C. 9 


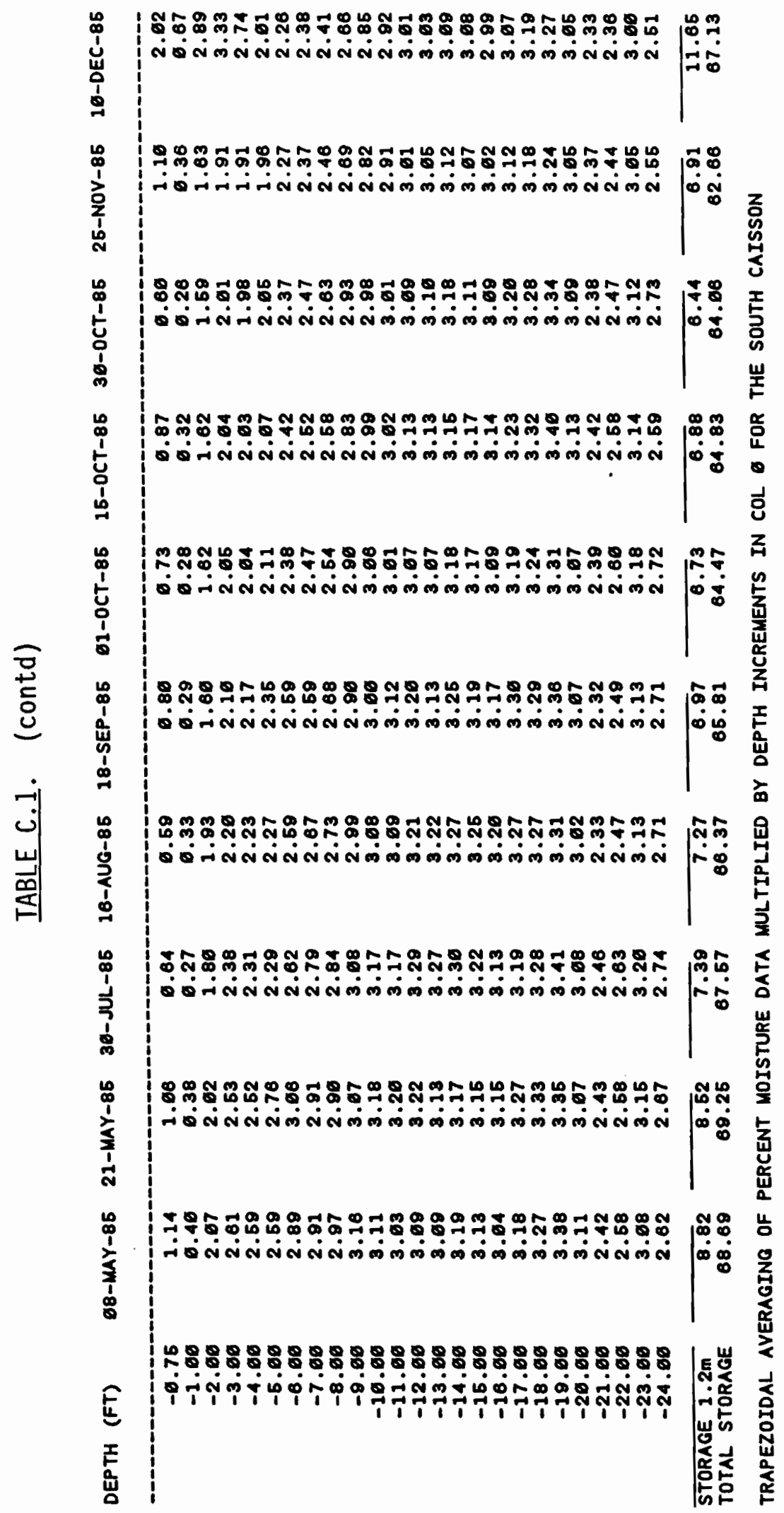

C. 10 


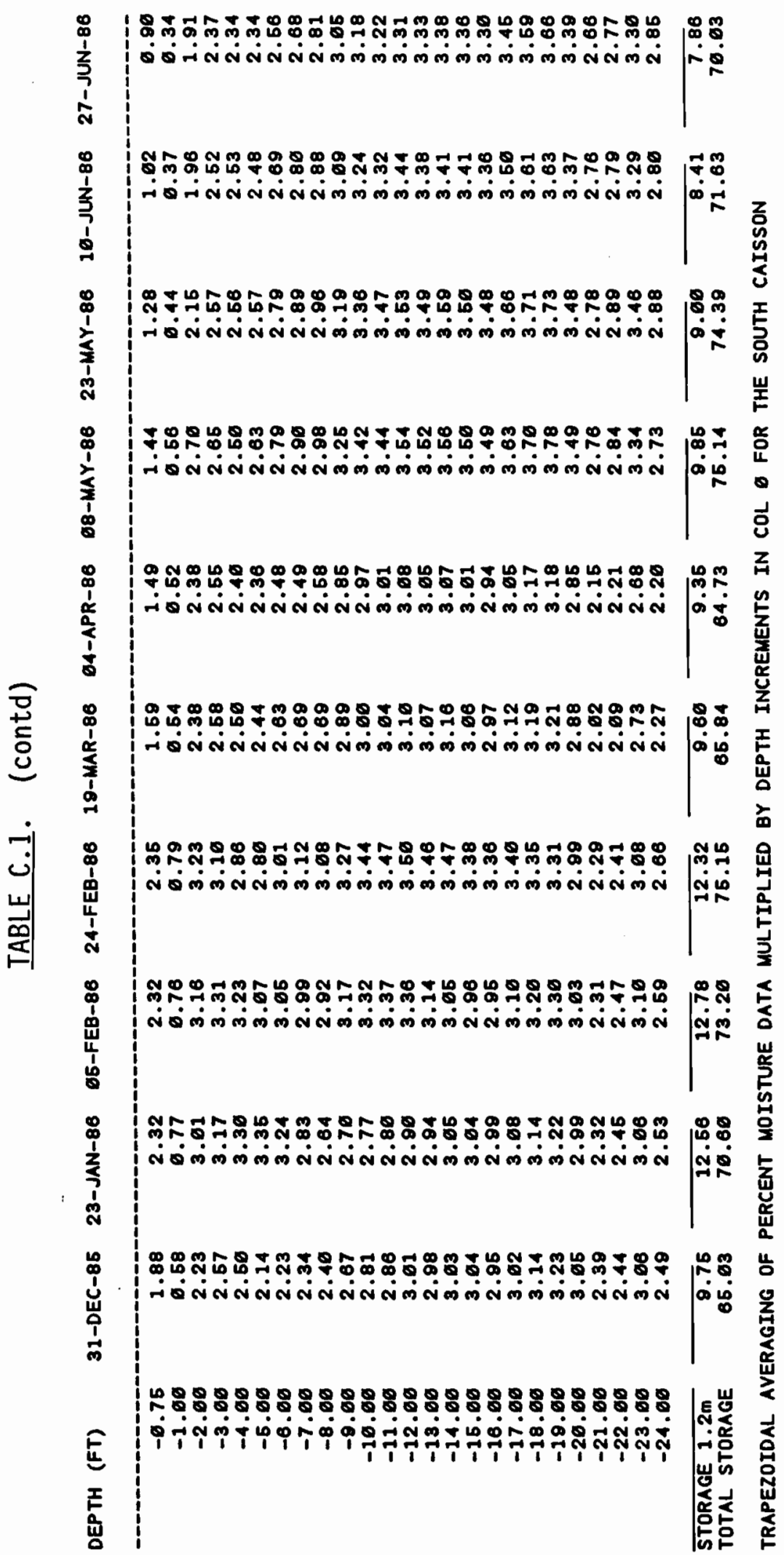

C. 11 


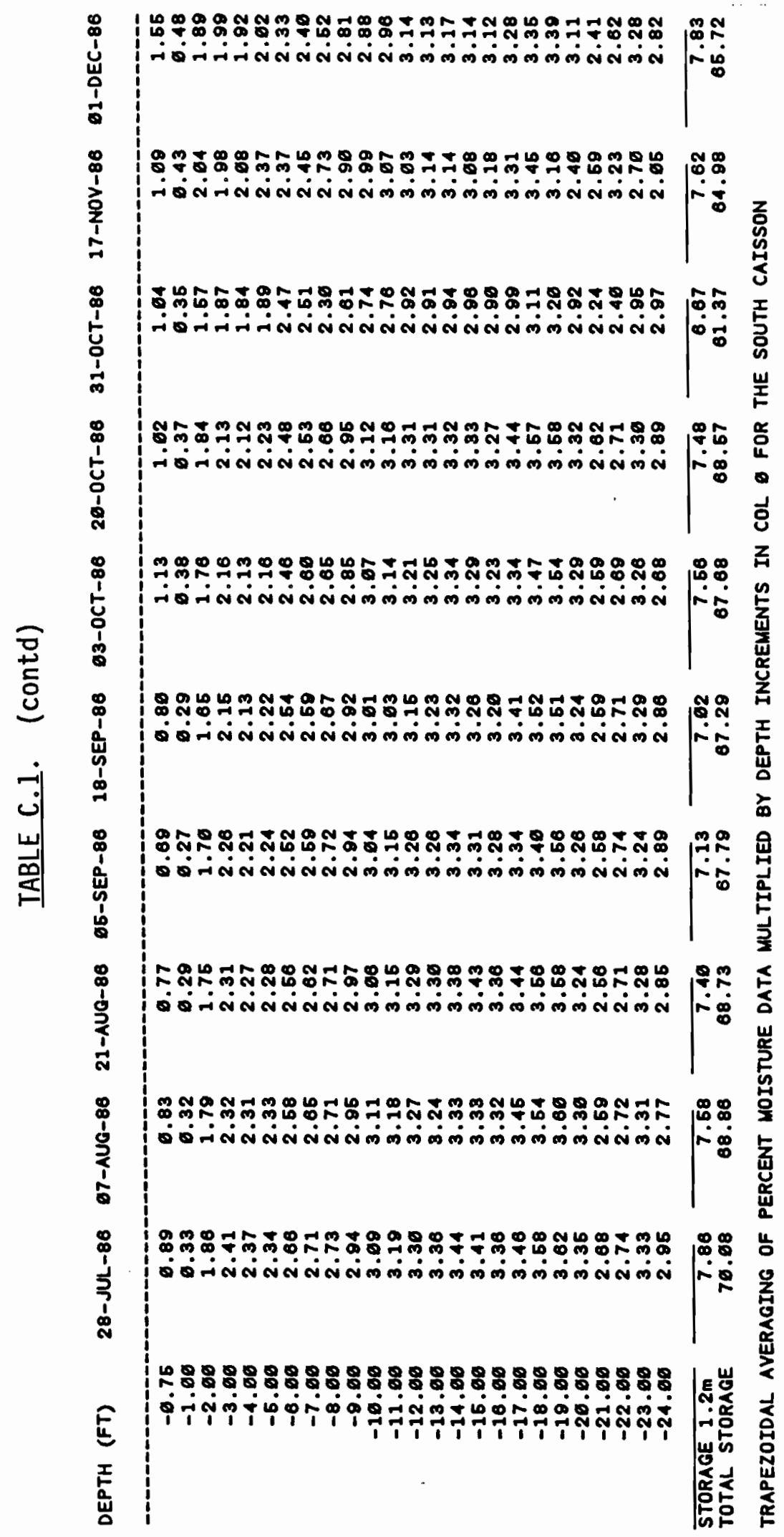

C. 12 


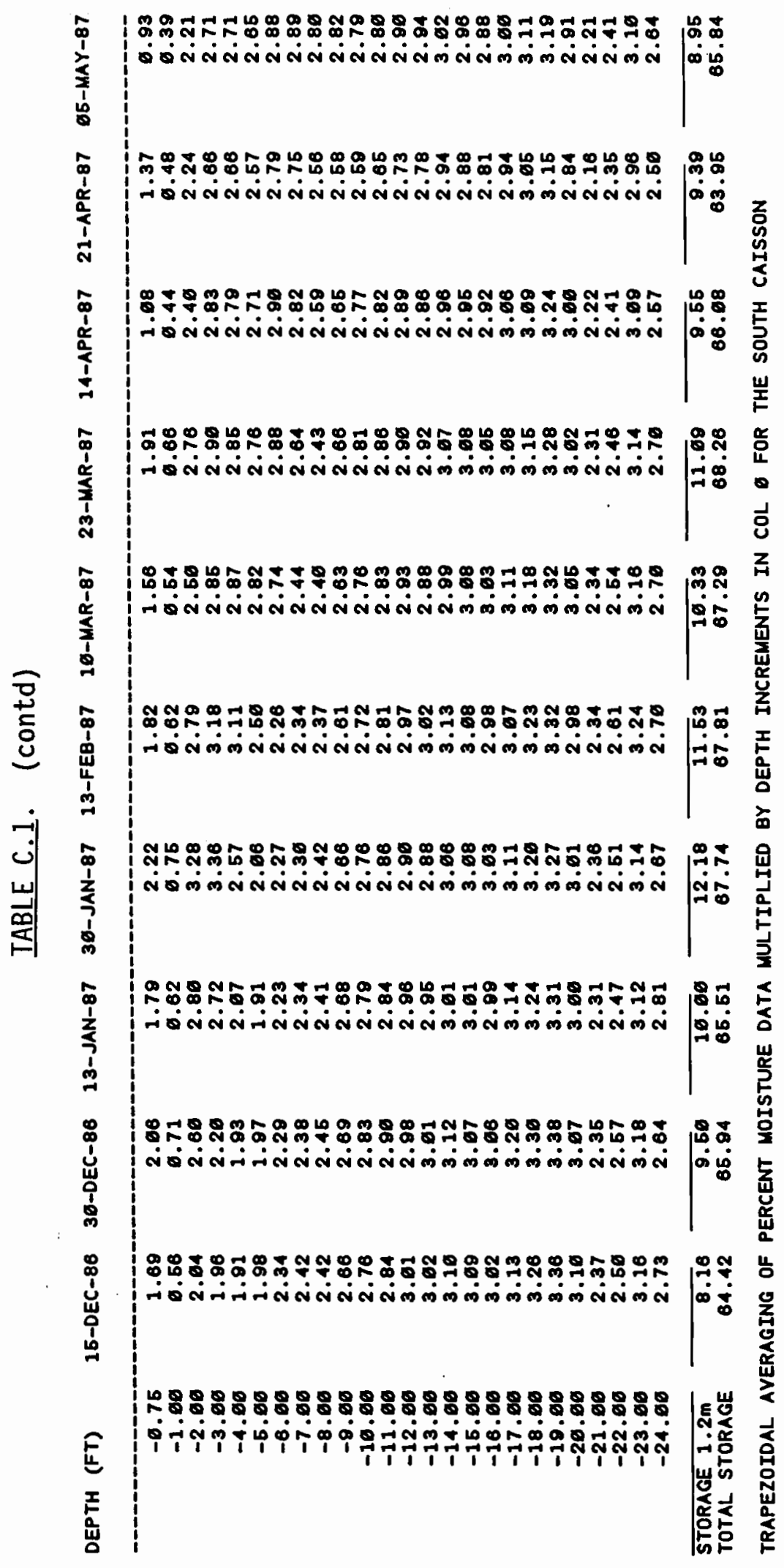




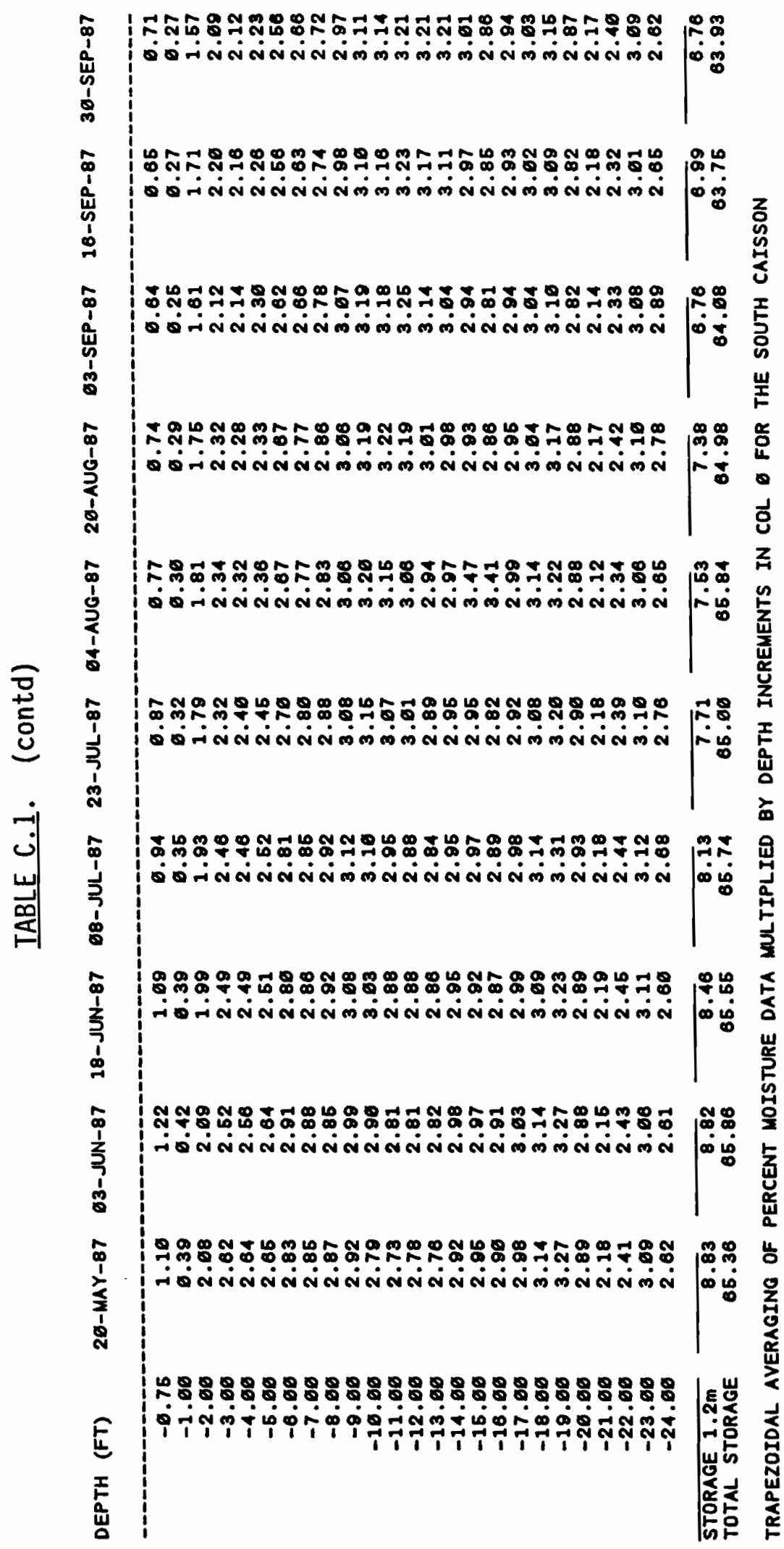

C. 14 


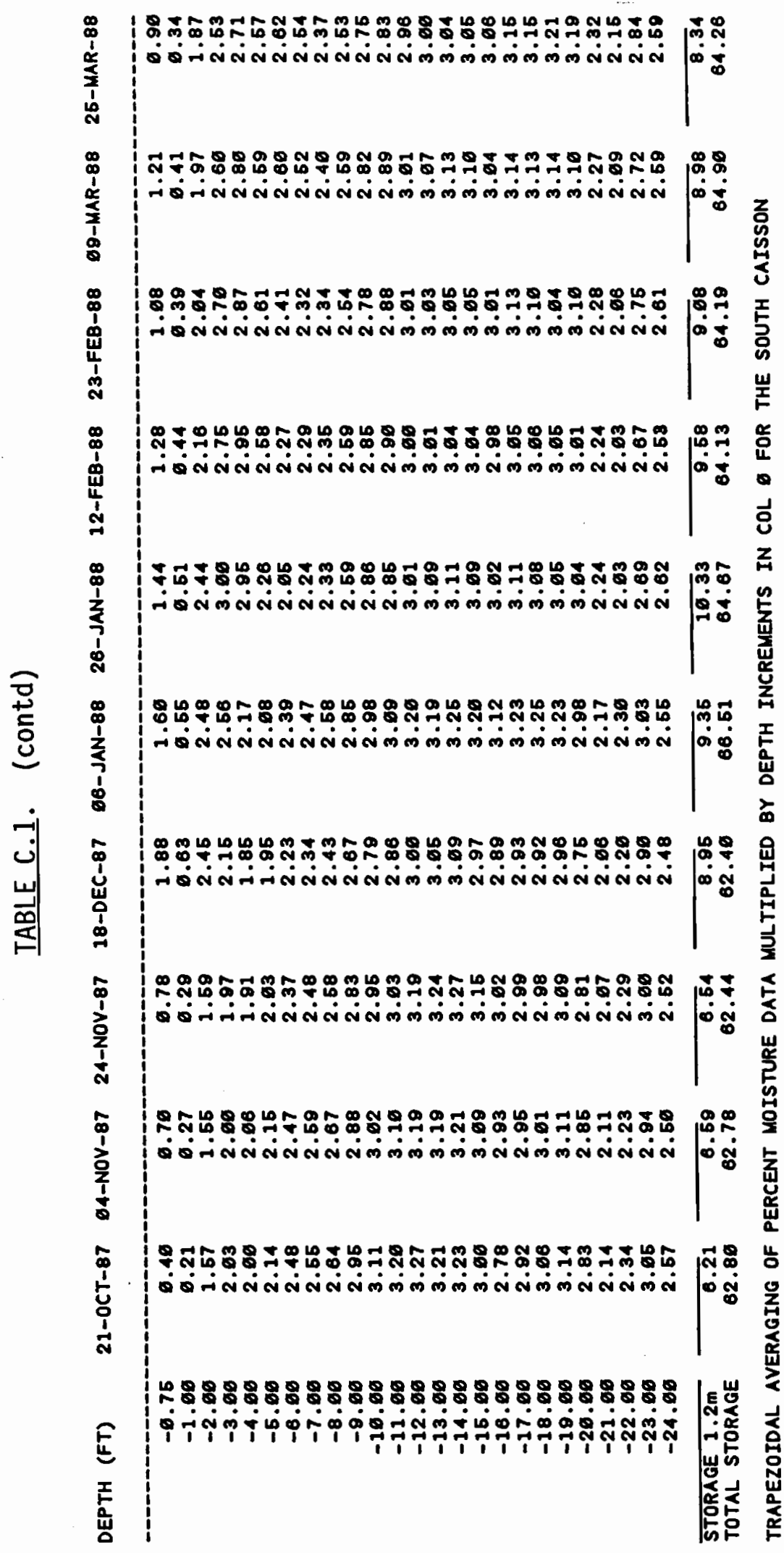

C. 15 


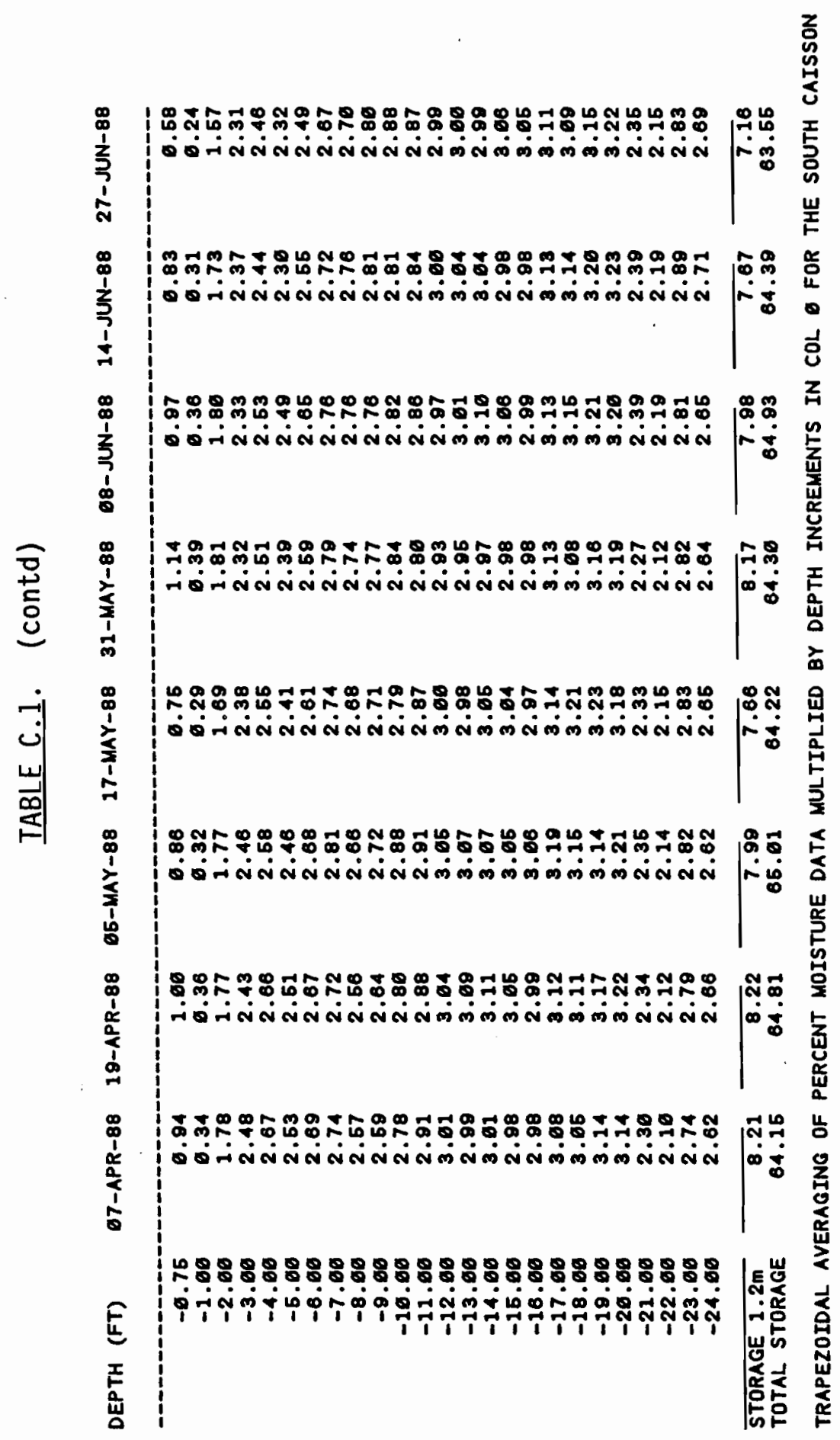

C. 16 


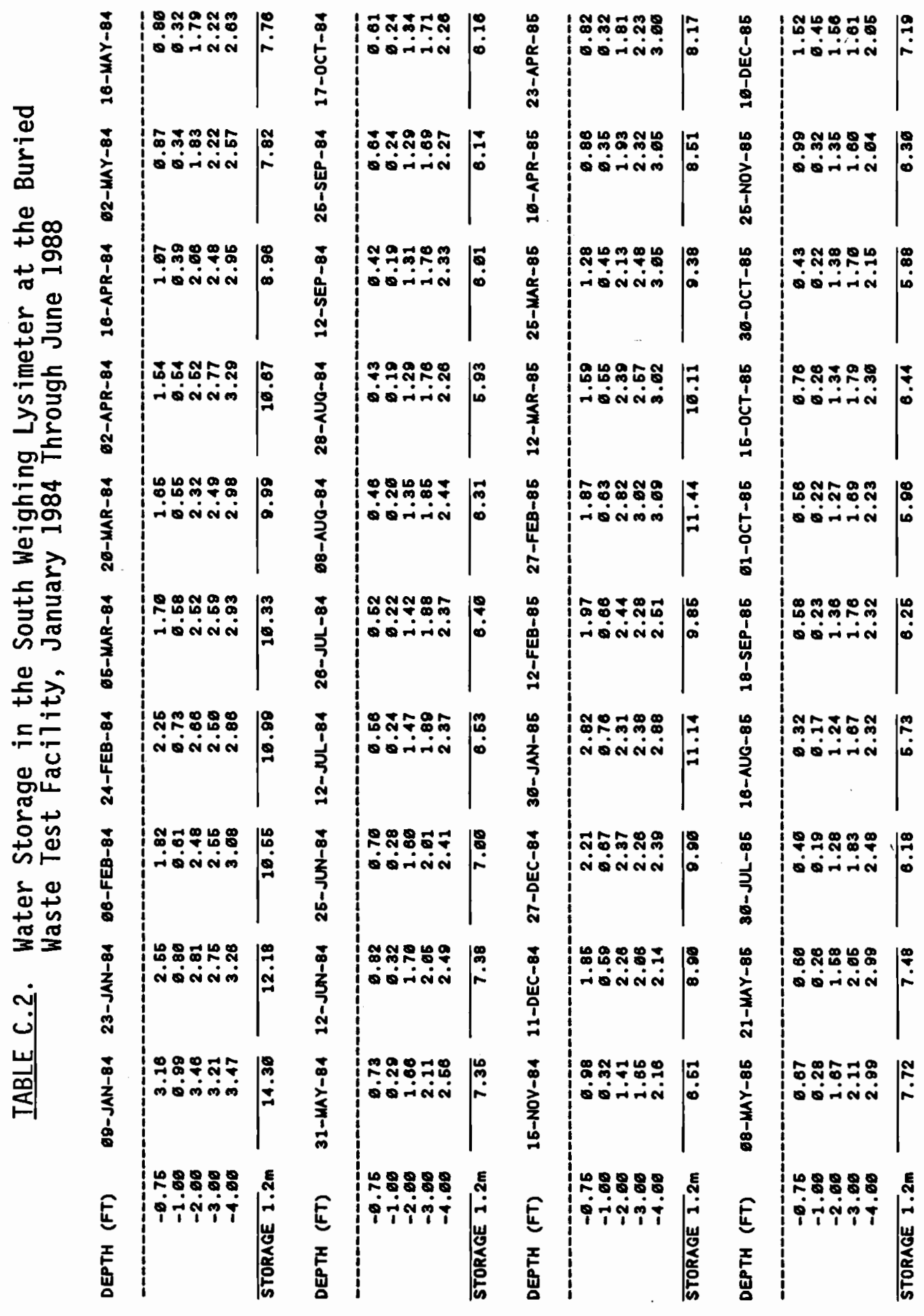




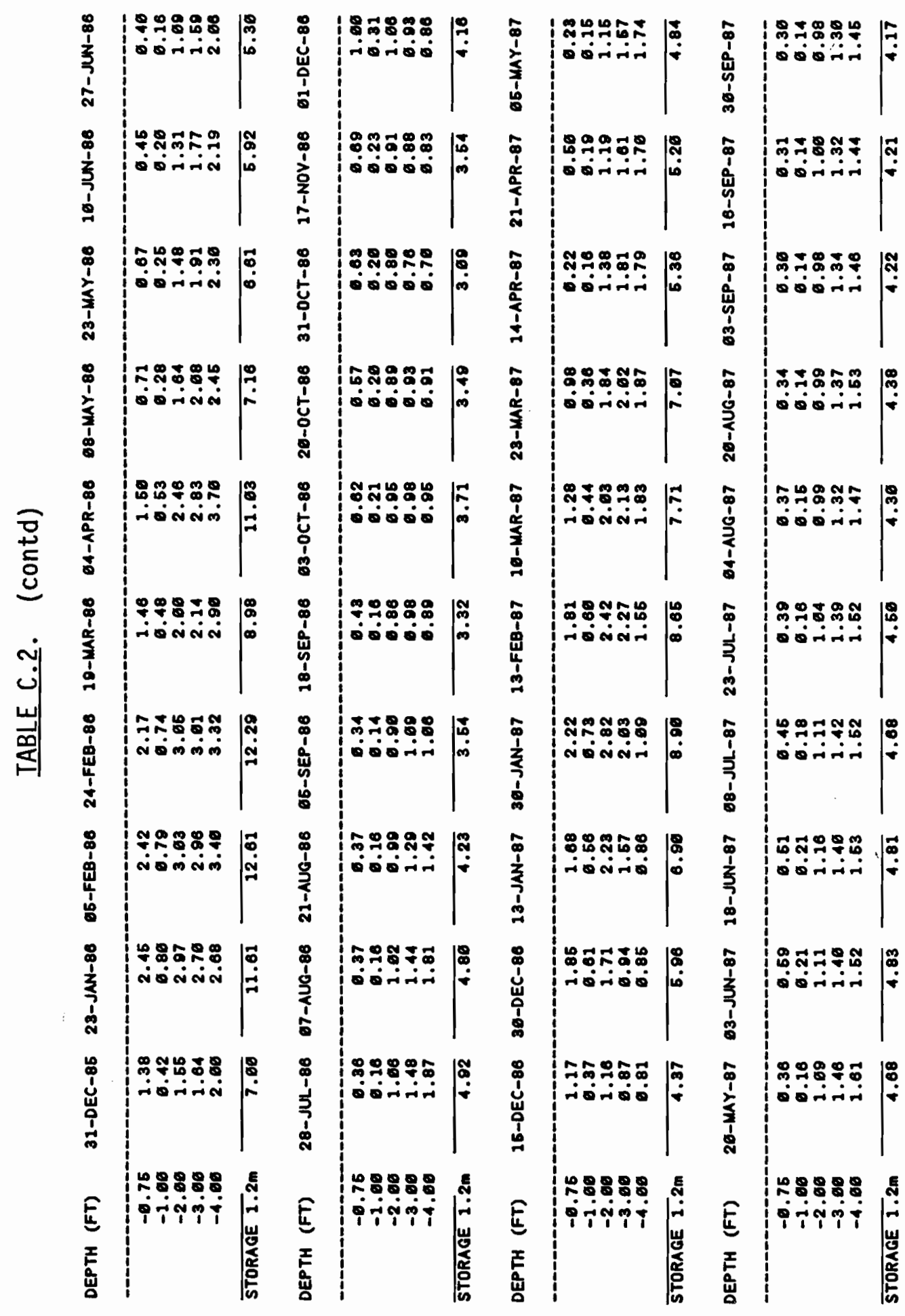




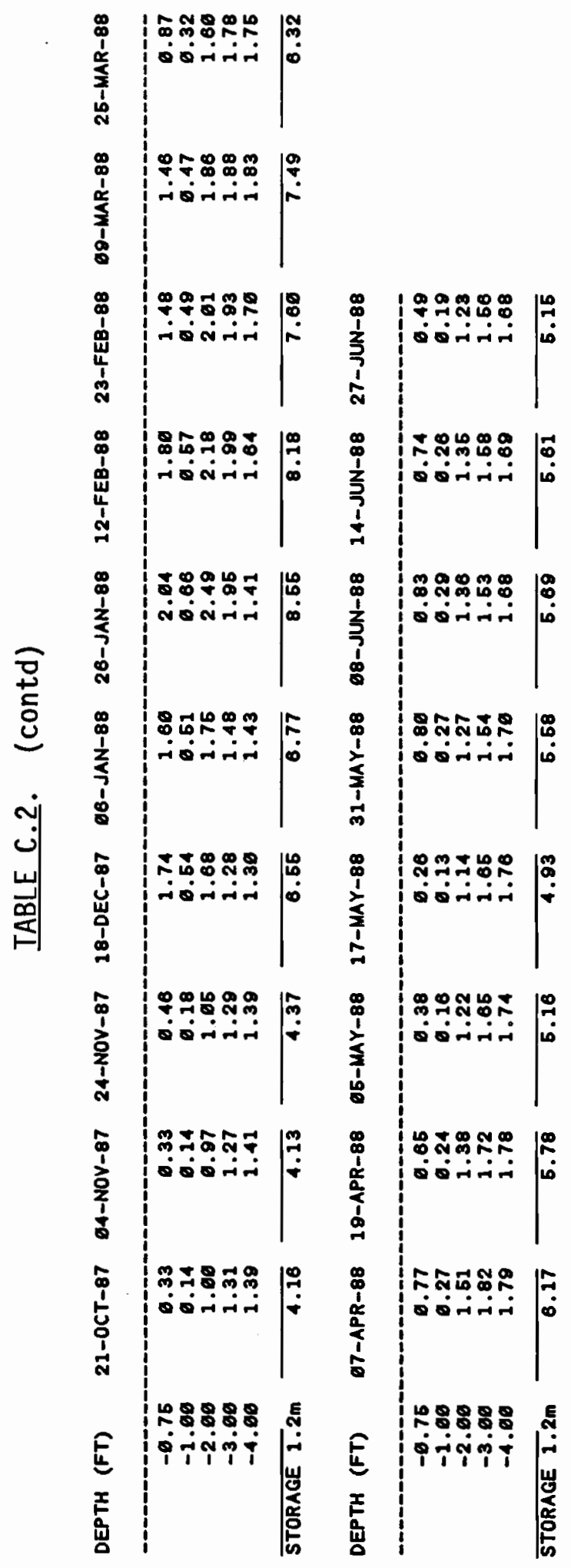

C. 19 


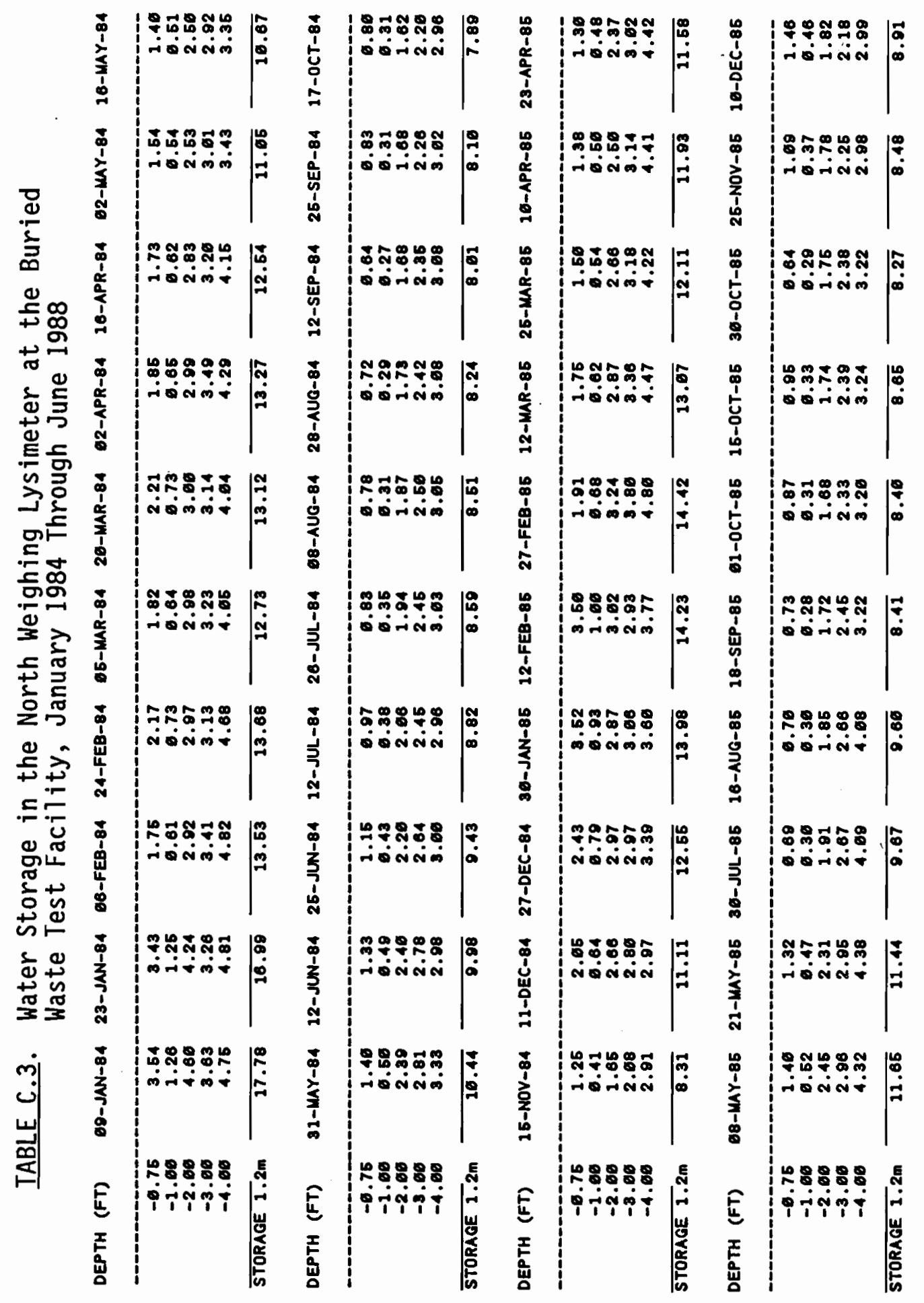




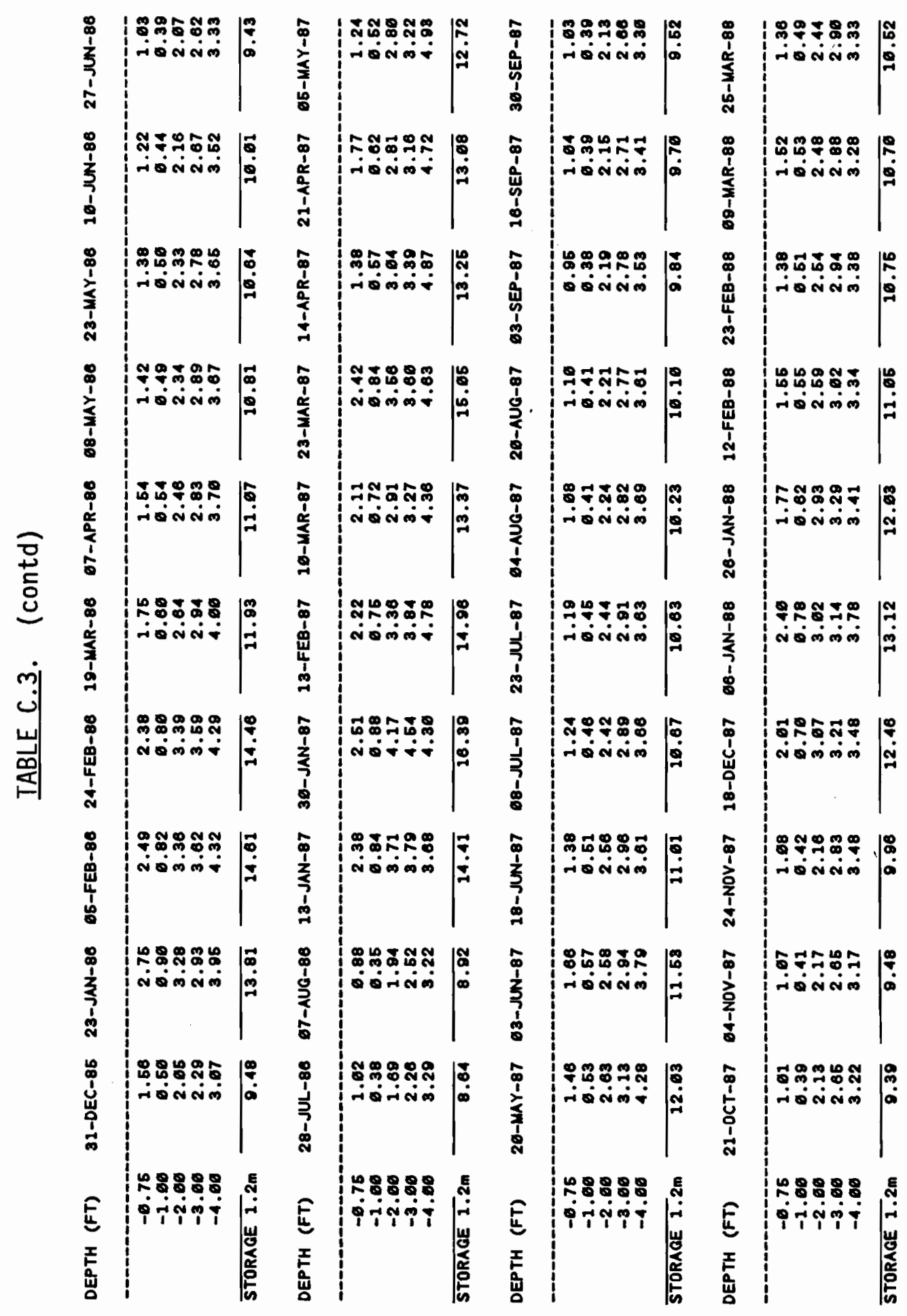




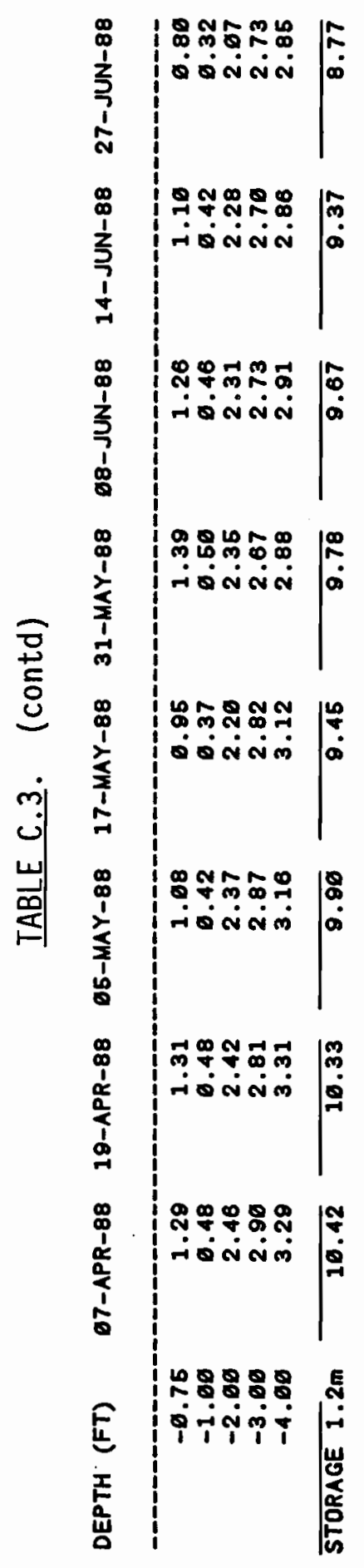

C. 22 


\section{APPENDIX D}

DRAINAGE MEASUREMENT PROCEDURE AND DATA 
Technical Procedure No. HSPA 2

TITLE: DRAINAGE MEASUREMENTS AT THE BURIED WASTE TEST FACILITY (BWTF)

\subsection{APPLICABILITY}

This procedure describes drainage measurements at the Buried Waste Test Facility (BWTF) located adjacent to the 300 North Burial Ground about $6 \mathrm{~km}$ northwest of the 300 Area at the Hanford site. Figures 1 and 2 show the location, plan view and cross sectional view of the BWTF.

\subsection{DEFINITIONS}

Lysimeters refers to a device (container of soil material) that limits water movement to one dimension, allows surface evaporation (and plant transpiration) and drainage to occur from the soil. The two types of lysimeters in use at the BWTF are drainage and weighing. The SC drainage lysimeter encloses a soil column 2.7-m in diameter and 7.6-m deep. Drainage water is removed from this lysimeter by pumping the free water that collects in the gravel pack located at the bottom of the SC lysimeter. The weighing lysimeters, NWL and SWL, enclose a soil block approximately $1.5 \mathrm{~m} \times 1.5 \mathrm{~m} \times 1.5 \mathrm{~m}$. Drainage water is removed from these lysimeters by applying subatmospheric pressure to suction candles located at the bottom of the lysimeters.

Drainage means water collected from the lysimeters other than that obtained during deliberate water input (i.e., leak testing may occur periodically throughout the life time of the facility). Water collected from the drain ports of the lysimeters over the course of the test period constitutes drainage water.

\subsection{RESPONSIBLE STAFF}

Field Personnel, or Project Manager.

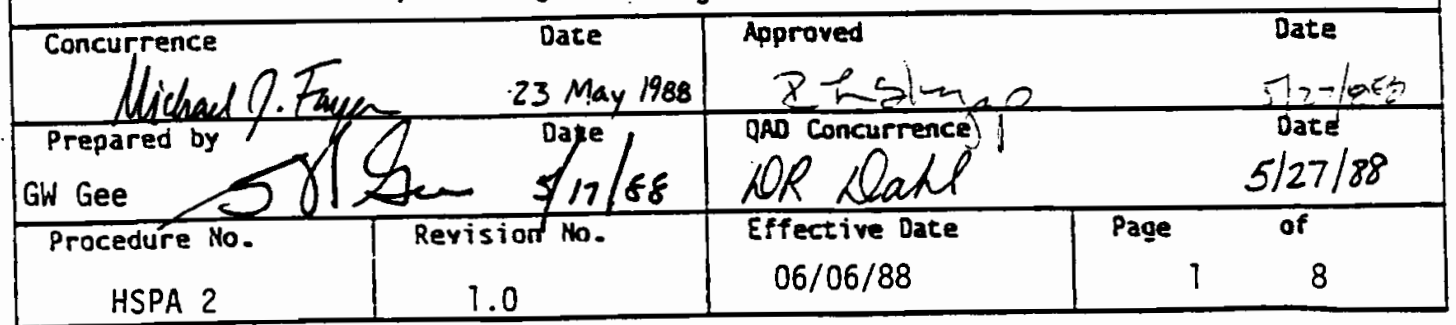

FIGURE D.1. Procedure for Measuring Drainage at the Buried Waste Test Facility 


\subsection{PROCEDURE}

\subsection{MATERIALS}

4.1.1 Carboy containers - 20 to 40L. Large enough to handle up to $20 \mathrm{~L}$ of drainage.

4.1.2 Scales - Laboratory platform type. Resolution of $\pm 1 \mathrm{~g}$ with capacity of $25 \mathrm{~kg}$.

4.1.3 Pumps. Figure 3 shows the schematic of pumps used to draw water from the lysimeters.

\subsection{SCHEDULE}

Three lysimeters are being sampled, the NWL; SWL, and SC as described in Figure 2. Sampling of drainage is done periodically, on an as-needed basis. During periods of active drainage, an adequate sampling period is twice per month. When lysimeters are draining slowly (e.g.. less than one liter per sampling), a sampling period of once every three months may be an adequate schedule. As an example, the South Weighing Lysimeter (SWL) has not drained for almost two years. Thus the actual sampling schedule is dependent upon the amounts of drainage occurring.

\subsection{PROCEDURE}

The procedure for collection of drainage water is described as follows:

4.3.1 Check for drainage in the carboys located at the bottom of the North Weighing Lysimeter (NWL), the South Weighing Lysimeter (SWL), and the South Caisson (SC). If over $1 \mathrm{~L}$ has drained (in at least a two-week period), either repiace the carboy with an empty one or transfer the drainage water into a tared container and bring back into the laboratory for weighing.

4.3.2 Weigh the carboy and water on a calibrated scale to the nearest gram. Remove the water and weigh the carboy empty. Record the date, who made the measurement, what was measured, what M\&TE scale

\begin{tabular}{|l|c|c|rr|}
\hline Procedure No. & Revision No. & Effective Date & Page & of \\
HSPA 2 & 1.0 & $06 / 06 / 88$ & 2 & 8 \\
\hline
\end{tabular}

\section{FIGURE 0.1. (contd)}




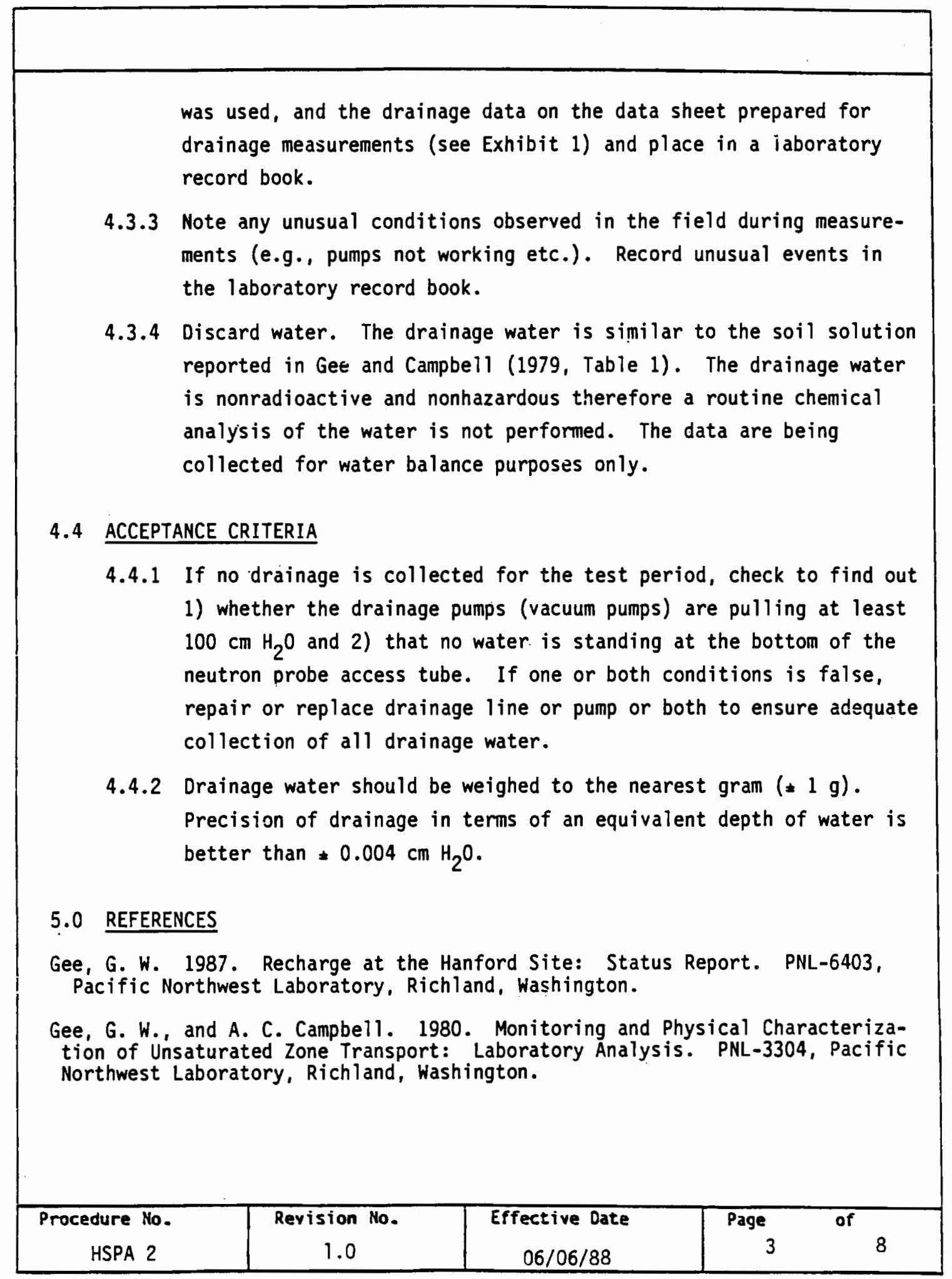

FIGURE 0.1. (contd) 
Gee, G. W., and T. L. Jones. 1985. Lysimeters at the Hanford Site: Presert Use and Future Needs. PNL-5578, Pacific Northwest Laboratory, Richland, Washington.

Kirikham, R. R., G. W. Gee, and J. L. Downs. 1987. An Experimental P.lan for the Field Lysimeter Test Facility (FLTF). PNL-6351, Pacific Northwest Laboratory, Richland, Washington.

Phillips, S. J., A. C. Campbell, M. D. Campbel1, G. W. Gee, H. H. Hoober, and K. 0. Schwarzmiller. 1979. A Field Test Facility for Monitoring Water/ Radionuclide Transport Through Partially Saturated Geologic Media: Design Construction and Preliminary Description. PNL-3226, Pacific Northwest Laboratory, Richland, Washington.

Procedure io. HSPA 2

Revision hlo.
1.0

FIGURE D.

FIGURE 0.1. (conts) 


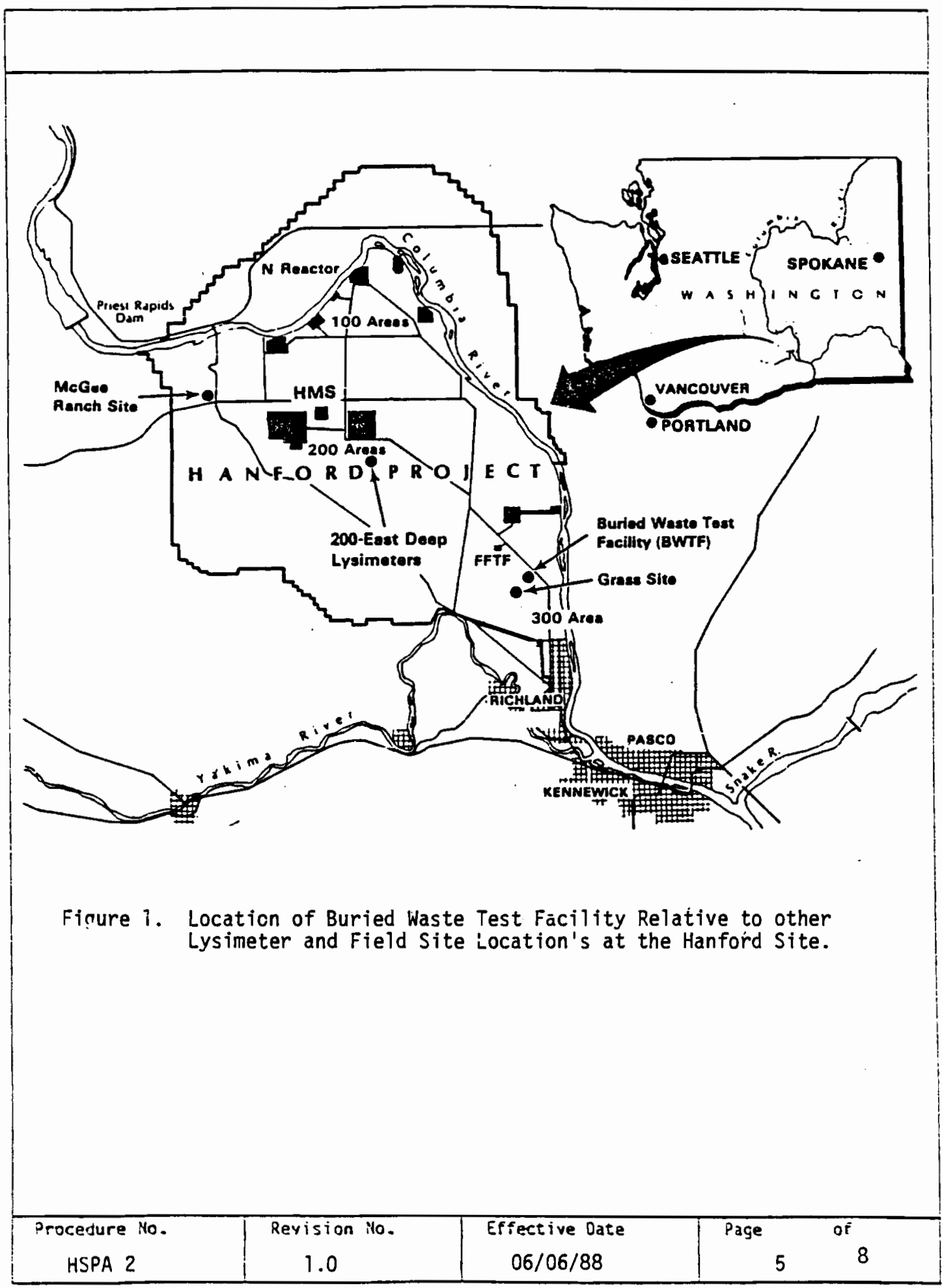

FIGURE 0.1. (contd) 


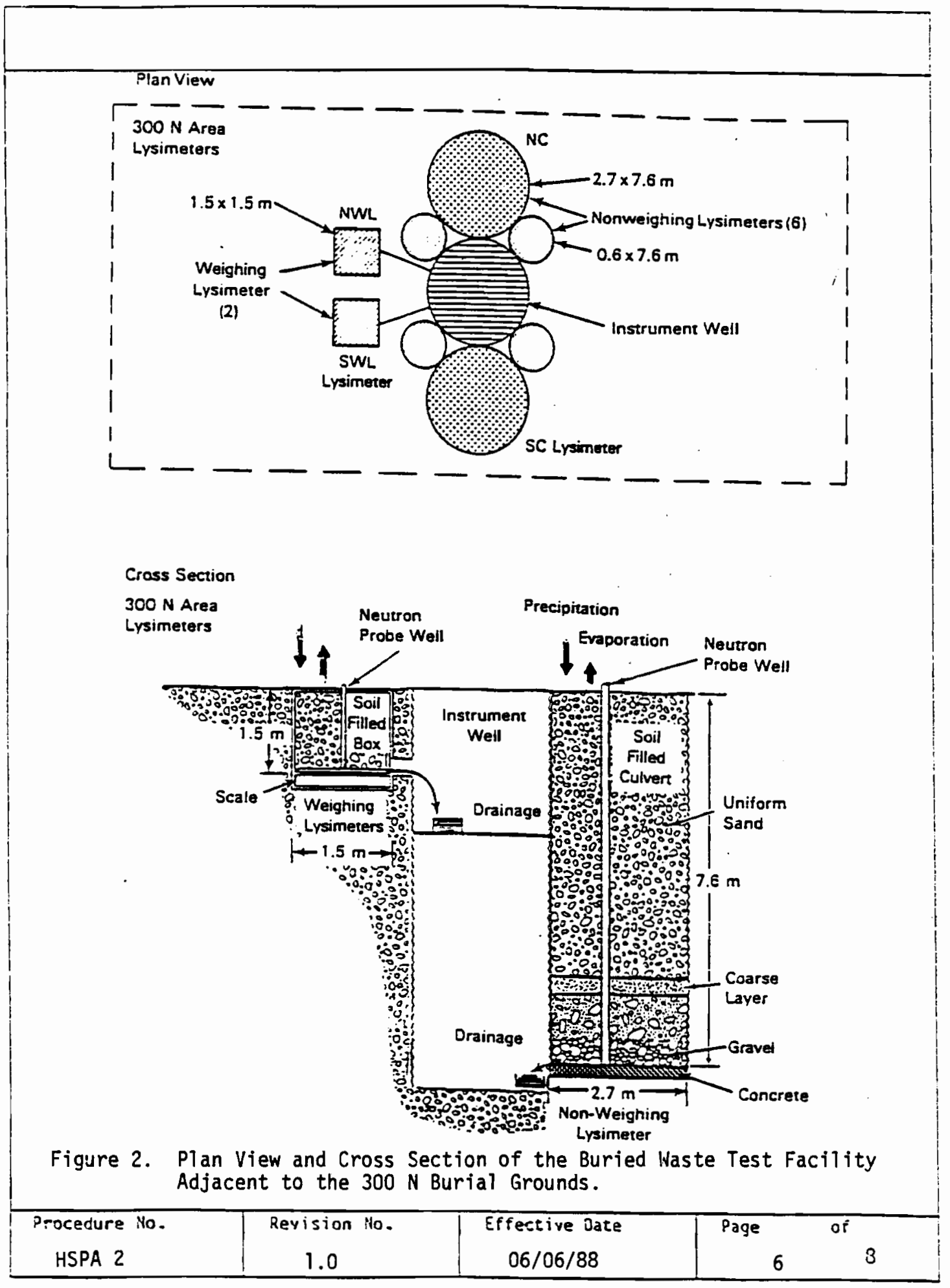

FIGURE D.I. (contd) 


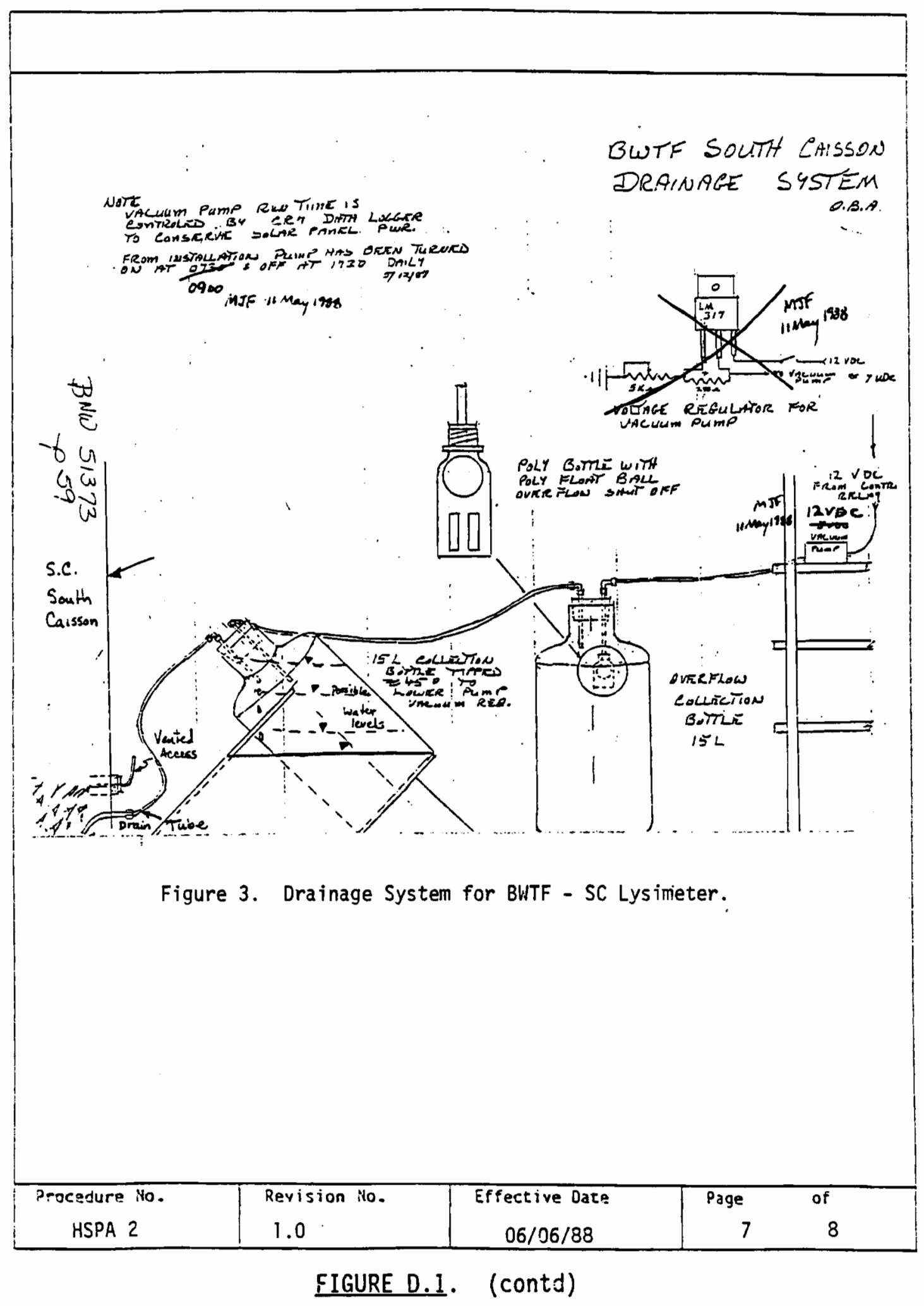




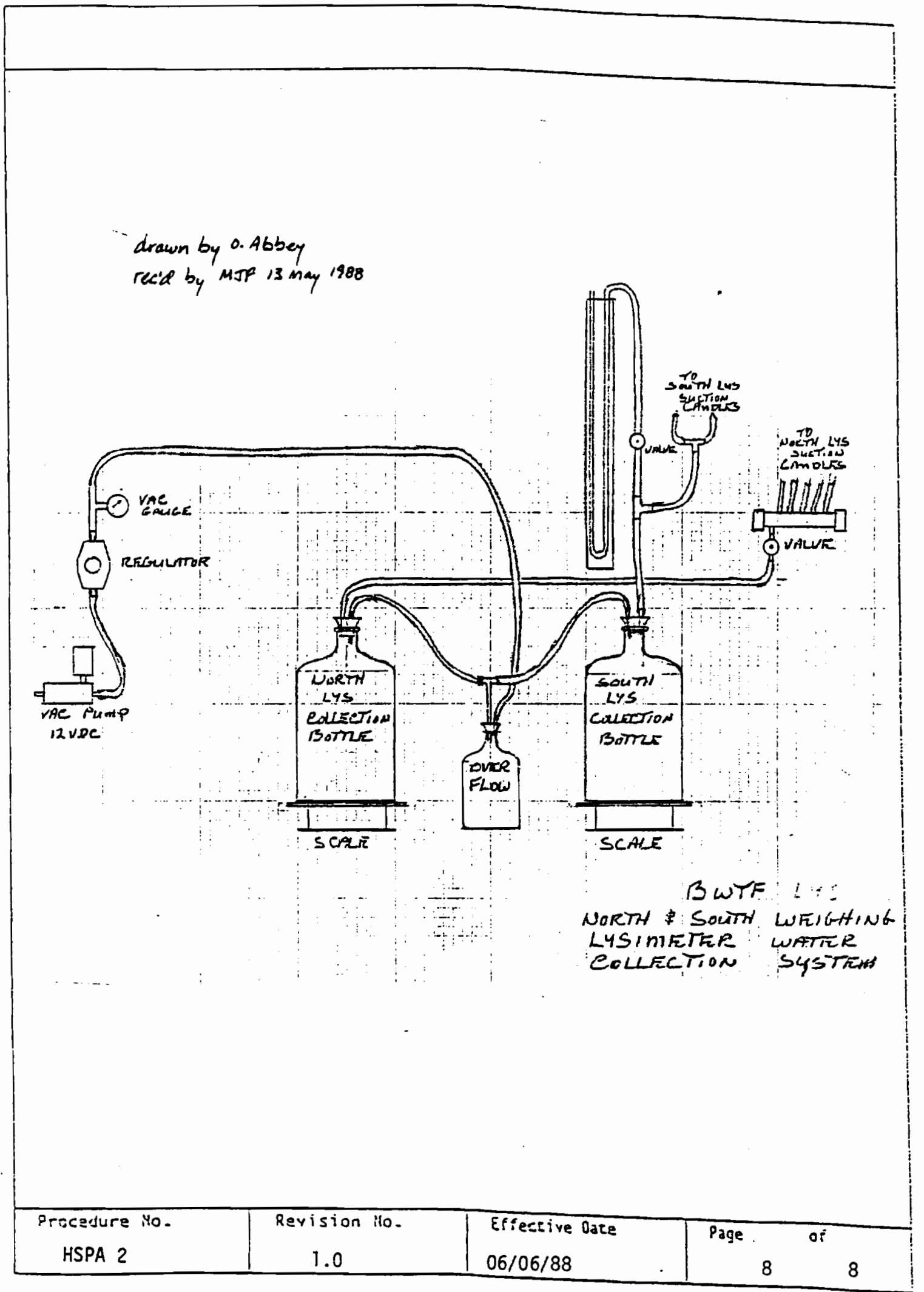

FIGURE D.1. (contd) 


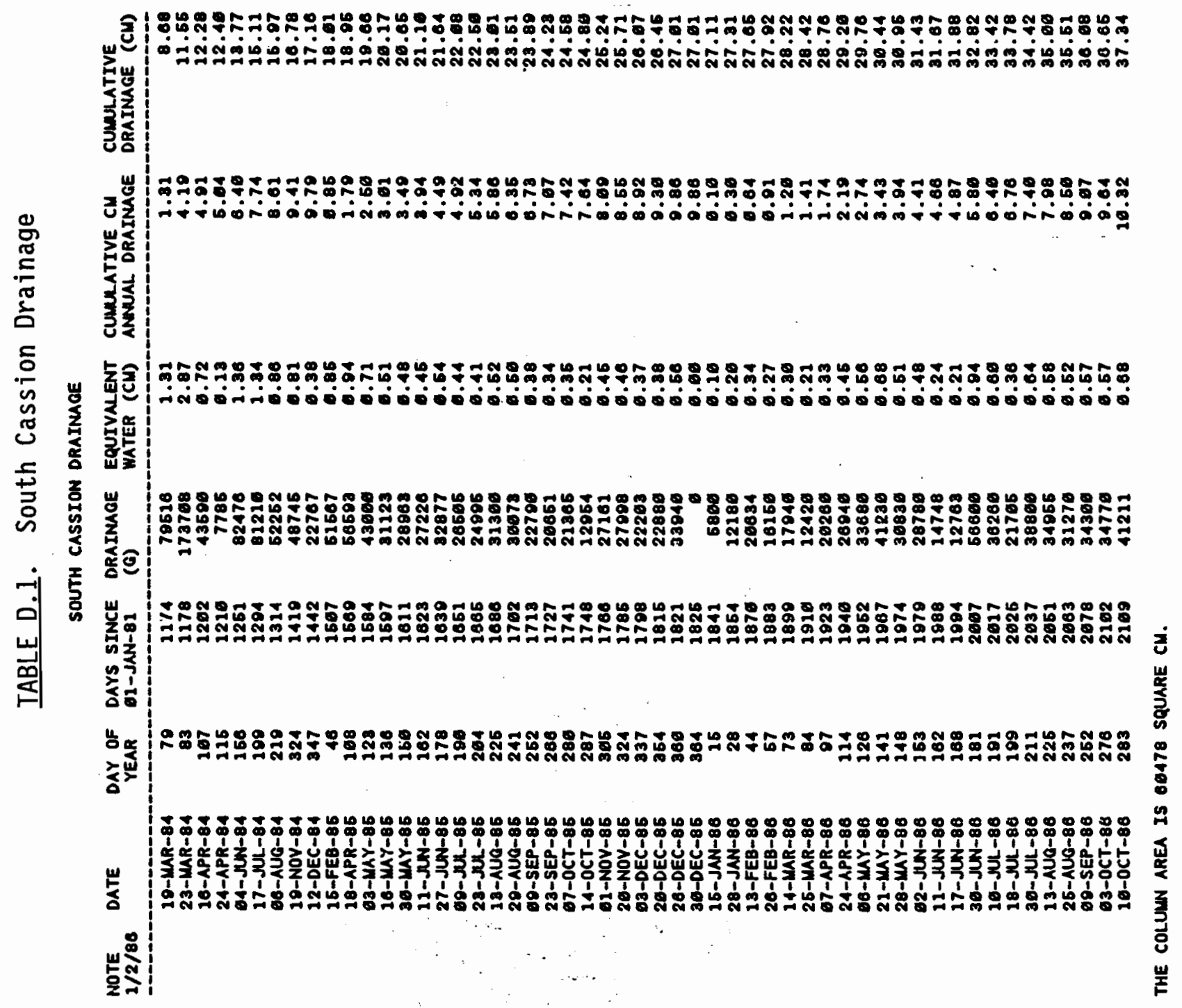

0.9 


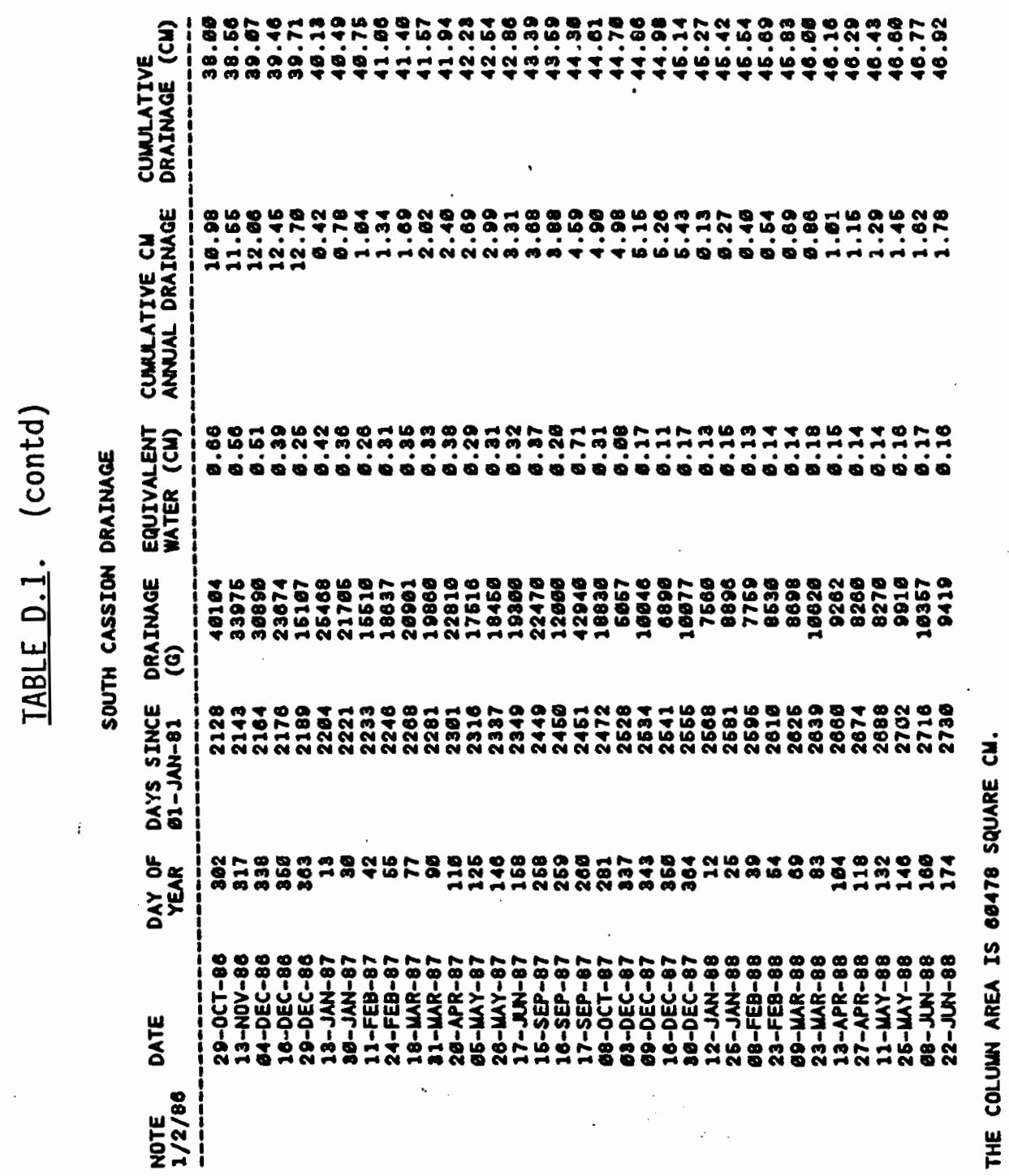

D. 10 


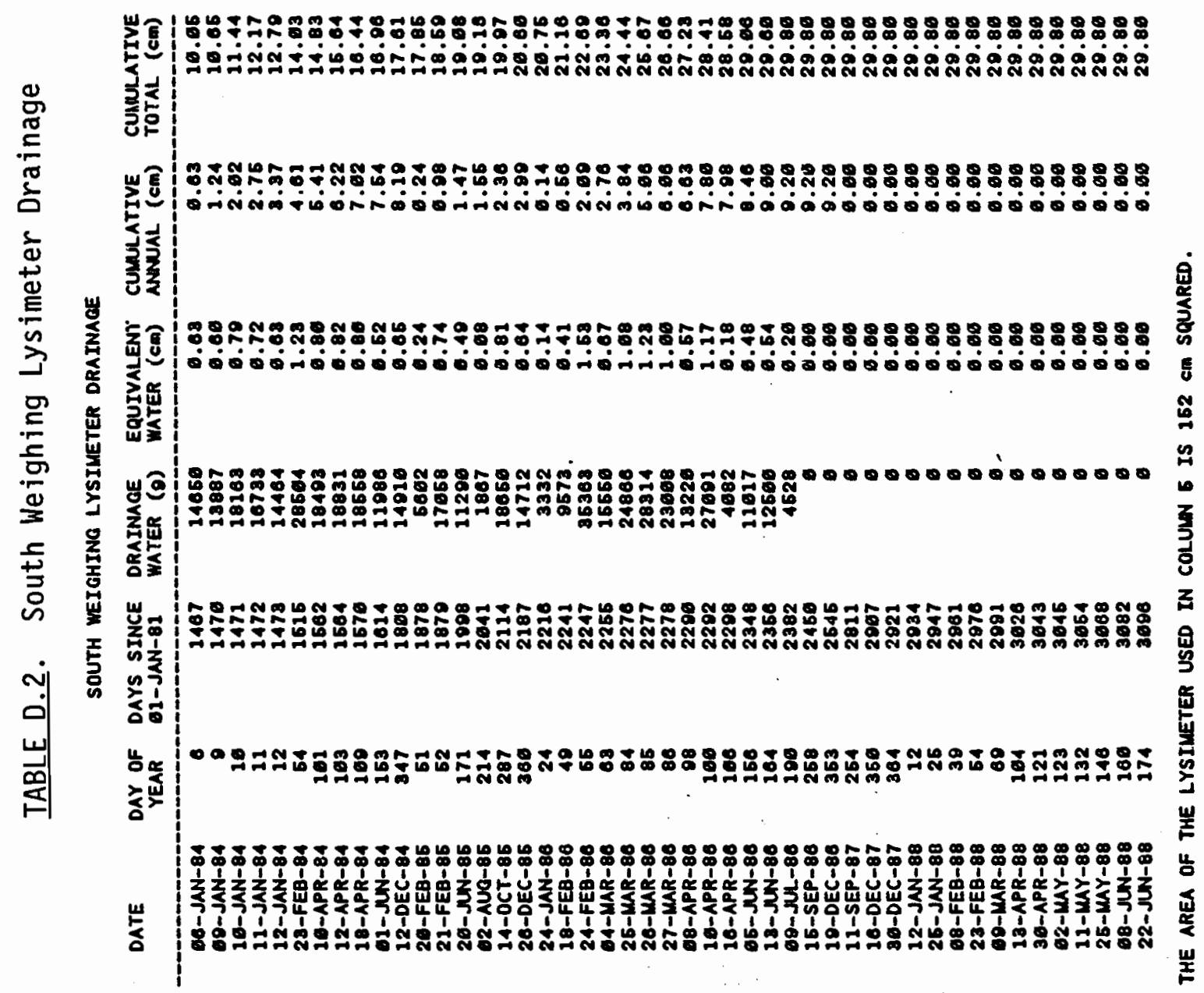




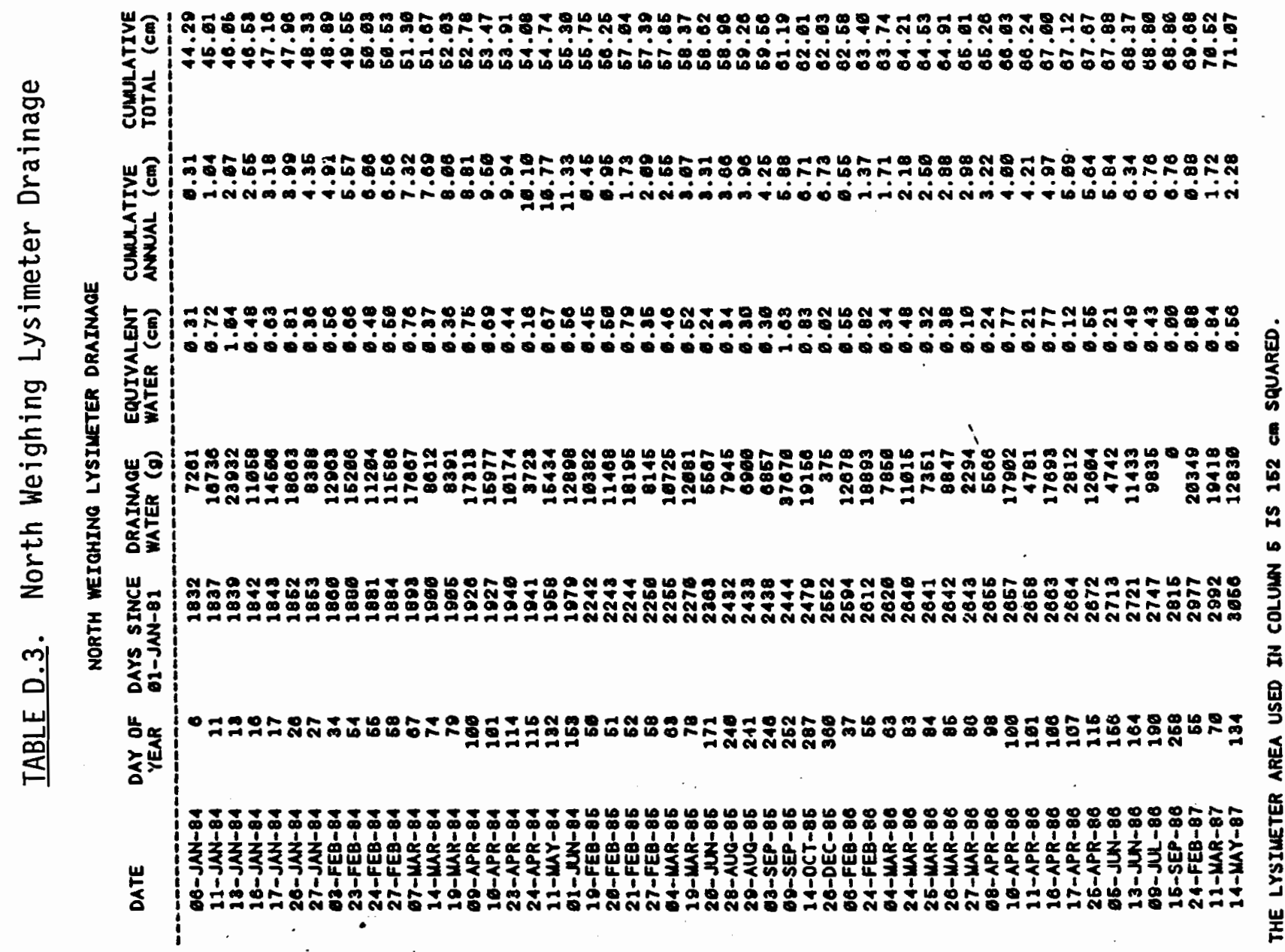

D. 12 


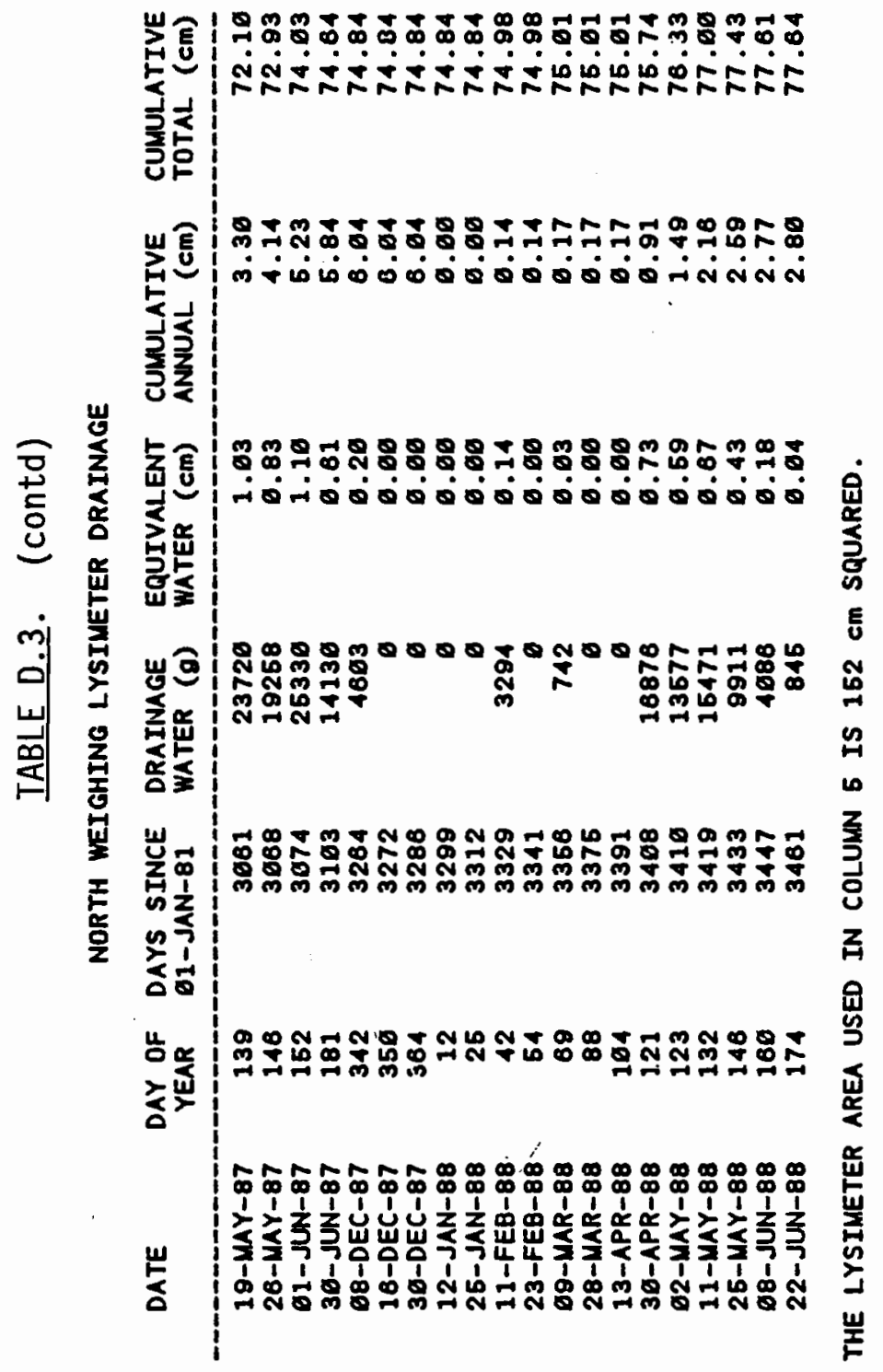

D. 13 


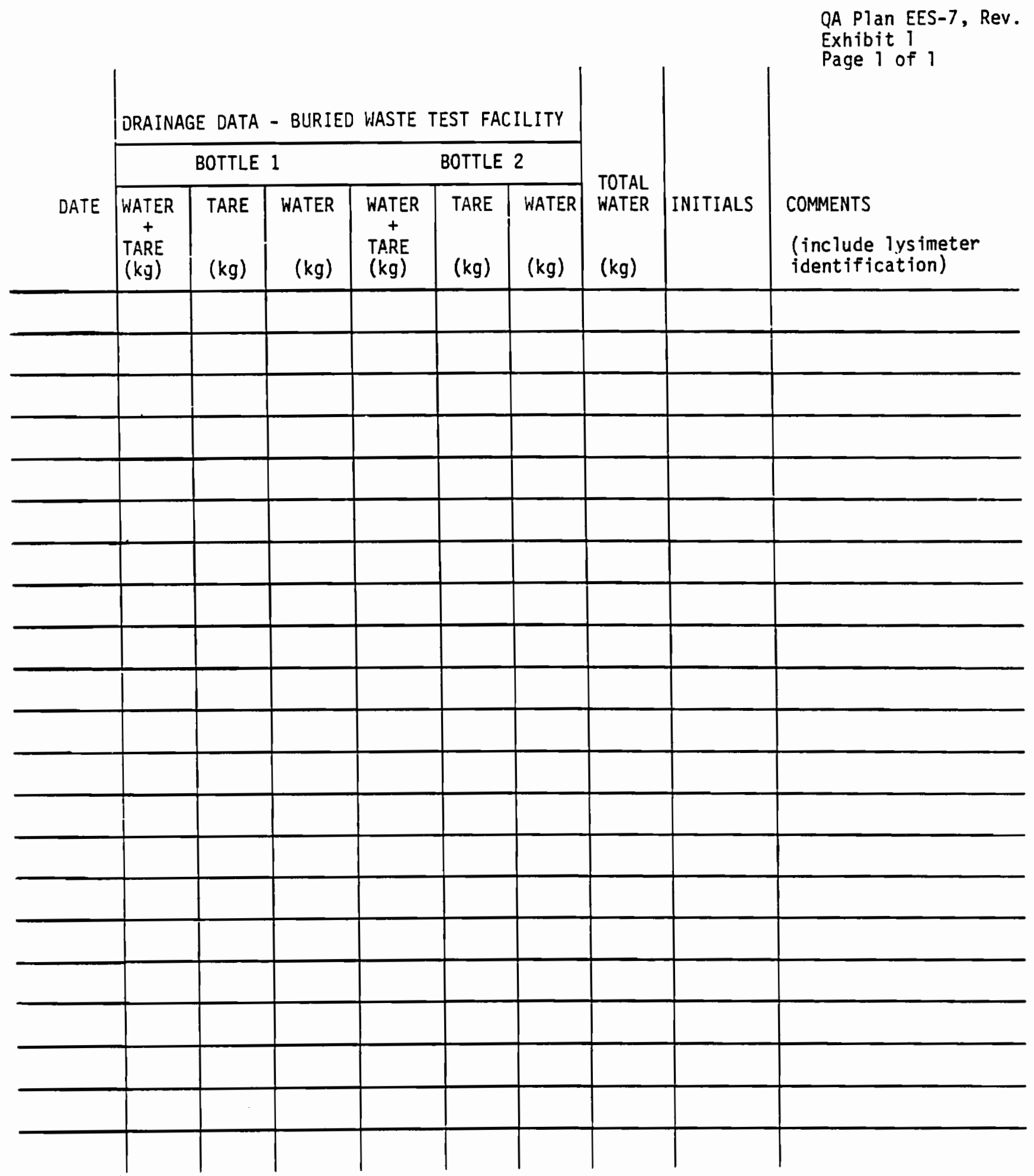

FIGURE D.2. Data Sheet for Drainage Record at the Burial Waste Test Facility 
APPENDIX E

HYDRAULIC PROPERTIES DATA 


\section{APPENDIX E}

\section{HYDRAULIC PROPERTIES DATA}

TABLE E.1. Water Content Data $\left(\mathrm{cm}^{3} / \mathrm{cm}^{3}\right)$ from Grass Site (first experiment)

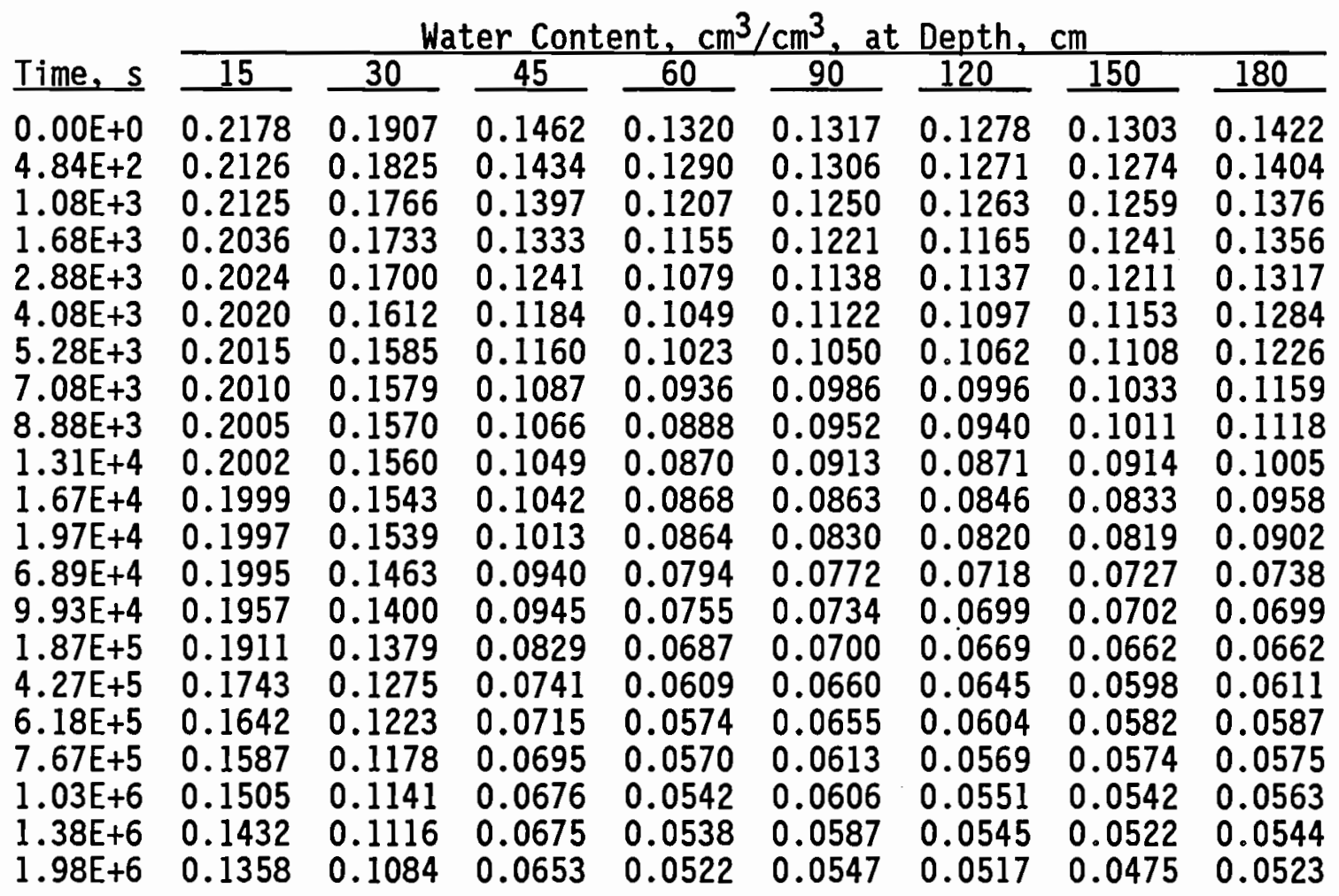


TABLE E.2. Matric Head Data from the Grass Site (first experiment)

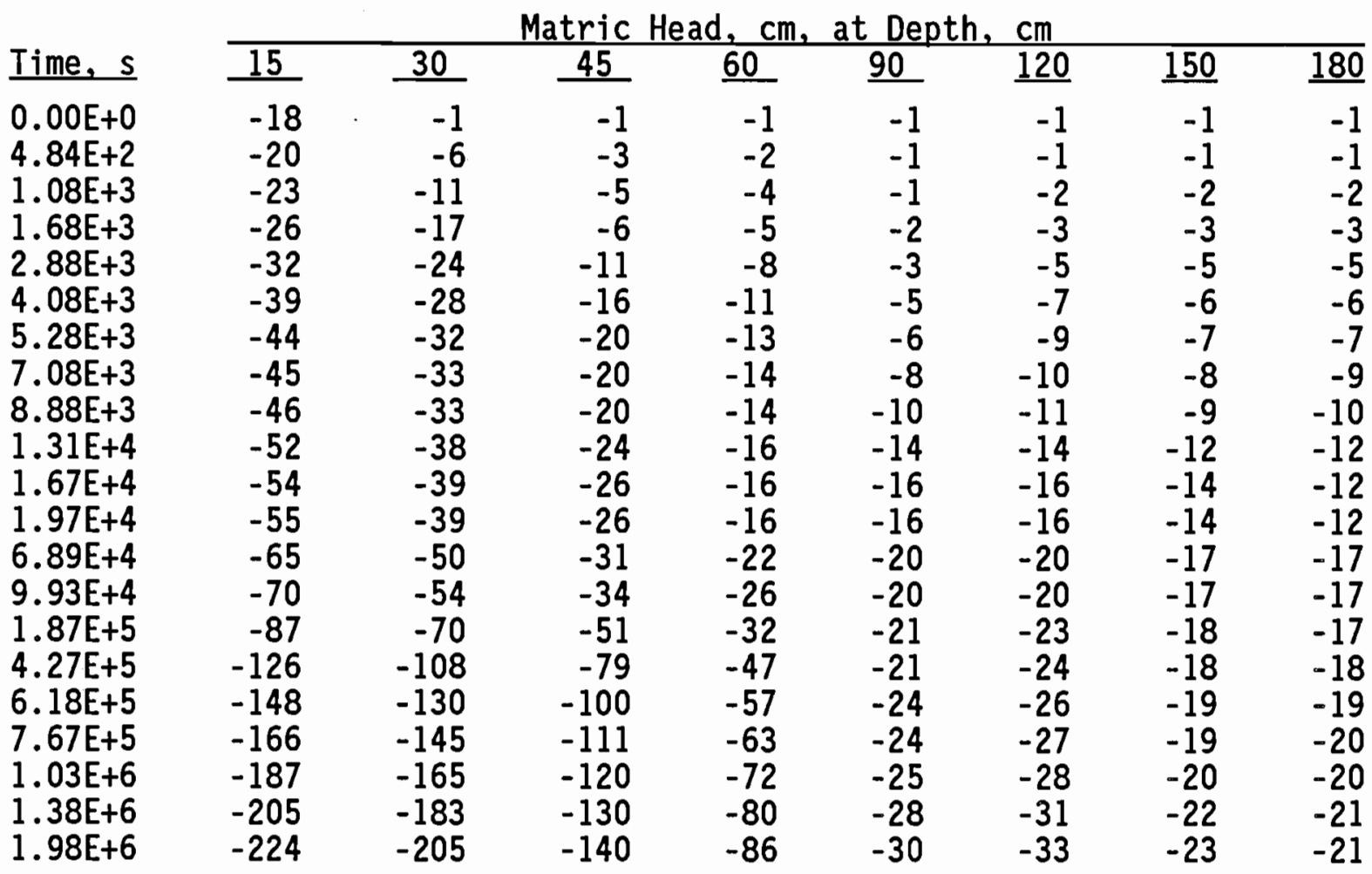

TABLE E.3. Time-Averaged Water Content from the 300 Area Grass Site (first experiment)

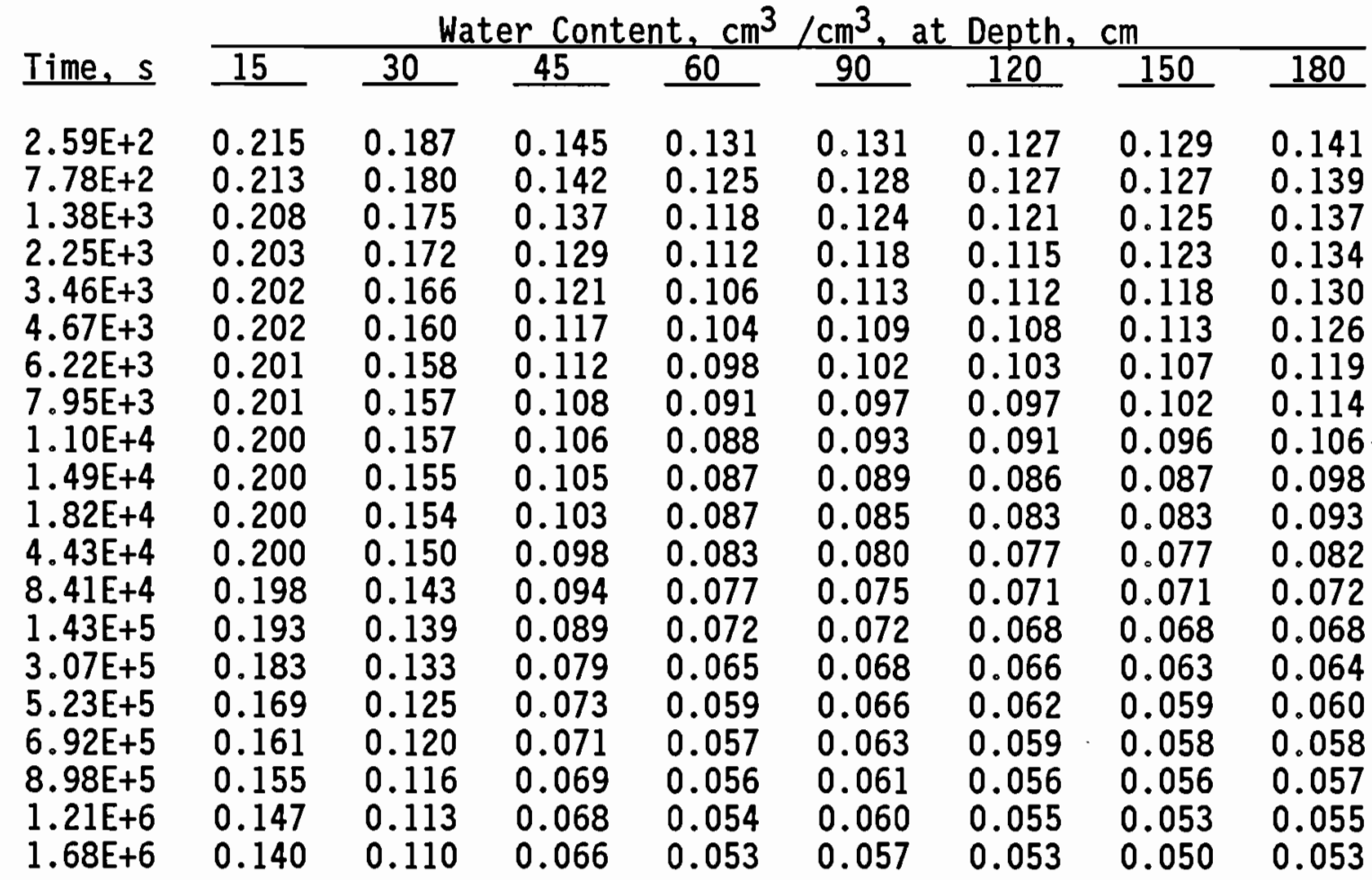


TABLE E.4. Hydraulic Conductivity from the Grass Site (first experiment)

Hydraulic Conductivity, $\mathrm{cm} / \mathrm{sec}$, at Depth, $\mathrm{cm}$

\begin{tabular}{|c|c|c|c|c|c|c|c|}
\hline ime, $s$ & 30 & 45 & 60 & 90 & 120 & 150 & 180 \\
\hline $\begin{array}{l}38 \mathrm{E}+3 \\
25 \mathrm{E}+3 \\
46 \mathrm{E}+3 \\
67 \mathrm{E}+3 \\
.22 \mathrm{E}+3 \\
95 \mathrm{E}+3 \\
10 \mathrm{E}+4 \\
49 \mathrm{E}+4 \\
82 \mathrm{E}+4 \\
43 \mathrm{E}+4\end{array}$ & $\begin{array}{l}1.87 \\
1.03 \\
1.36 \\
2.34 \\
1.2 \\
4.78 \\
6.65 \\
3.38 \\
8.1 \\
5.00 \\
-2 . \\
-2 . \\
-6.8 \\
-5.0 \\
-2 . \\
-1 . \\
-7.8 \\
-3\end{array}$ & $\begin{array}{l}7.3 \\
2.2 \\
3.4 \\
1.4 \\
1.1 \\
6.1 \\
2.5 \\
4.1 \\
4.6 \\
2.3 \\
8.7 \\
-2 . \\
-1 . \\
-8 . \\
-5 . \\
-2 .\end{array}$ & $\begin{array}{l}7.0 \\
2.6 \\
2.6 \\
1.2 \\
1.5 \\
6.7 \\
1.8 \\
1.5 \\
2.4 \\
7.4 \\
9.1 \\
8.0 \\
1.3 \\
-4 . \\
-1 . \\
-1 .\end{array}$ & $\begin{array}{l}7.63 \mathrm{E}-4 \\
7.17 \mathrm{E}-4 \\
8.78 \mathrm{E}-4 \\
4.43 \mathrm{E}-4 \\
2.81 \mathrm{E}-4 \\
2.27 \mathrm{E}-4 \\
2.51 \mathrm{E}-4 \\
1.27 \mathrm{E}-4 \\
3.62 \mathrm{E}-5 \\
3.45 \mathrm{E}-5 \\
3.75 \mathrm{E}-5 \\
9.77 \mathrm{E}-6 \\
1.12 \mathrm{E}-5 \\
6.68 \mathrm{E}-6 \\
5.12 \mathrm{E}-6 \\
4.10 \mathrm{E}-6 \\
4.46 \mathrm{E}-6 \\
3.90 \mathrm{E}-6\end{array}$ & $\begin{array}{l}8.12 \mathrm{E}-4 \\
8.53 \mathrm{E}-4 \\
1.15 \mathrm{E}-3 \\
5.50 \mathrm{E}-4 \\
3.27 \mathrm{E}-4 \\
3.40 \mathrm{E}-4 \\
3.40 \mathrm{E}-4 \\
1.96 \mathrm{E}-4 \\
7.50 \mathrm{E}-5 \\
6.74 \mathrm{E}-5 \\
6.94 \mathrm{E}-5 \\
1.51 \mathrm{E}-5 \\
1.39 \mathrm{E}-5 \\
7.31 \mathrm{E}-6 \\
4.38 \mathrm{E}-6 \\
2.80 \mathrm{E}-6 \\
2.99 \mathrm{E}-6 \\
1.57 \mathrm{E}-6\end{array}$ & $\begin{array}{l}9.24 \mathrm{E}-4 \\
9.18 \mathrm{E}-4 \\
1.46 \mathrm{E}-3 \\
6.36 \mathrm{E}-4 \\
4.61 \mathrm{E}-4 \\
4.57 \mathrm{E}-4 \\
4.73 \mathrm{E}-4 \\
2.63 \mathrm{E}-4 \\
1.36 \mathrm{E}-4 \\
1.15 \mathrm{E}-4 \\
9.33 \mathrm{E}-5 \\
2.17 \mathrm{E}-5 \\
1.62 \mathrm{E}-5 \\
8.80 \mathrm{E}-6 \\
5.23 \mathrm{E}-6 \\
3.43 \mathrm{E}-6 \\
3.60 \mathrm{E}-6 \\
1.98 \mathrm{E}-6\end{array}$ & $\begin{array}{l}3.0 \\
3.0 \\
2.0 \\
1.6 \\
1.3 \\
2.9 \\
1.8 \\
9.6 \\
5.5 \\
3.3 \\
3.3 \\
1.9 \\
1.0 \\
1.1\end{array}$ \\
\hline
\end{tabular}

IABLE E.5. Water Content Data from the Grass Site (second experiment)

\begin{tabular}{|c|c|c|c|c|c|c|c|c|}
\hline \multirow[b]{2}{*}{ Iime, $\underline{s}$} & \multicolumn{8}{|c|}{ Water Content, $\mathrm{cm}^{3} / \mathrm{cm}^{3}$, at Depth, $\mathrm{cm}$} \\
\hline & 15 & 30 & 45 & 60 & 90 & 120 & 150 & 180 \\
\hline $\begin{array}{l}0.00 \mathrm{E}+0 \\
8.99 \mathrm{E}+2 \\
1.32 \mathrm{E}+3 \\
2.76 \mathrm{E}+3 \\
4.50 \mathrm{E}+3 \\
5.70 \mathrm{E}+3 \\
7.02 \mathrm{E}+3 \\
8.70 \mathrm{E}+3 \\
1.08 \mathrm{E}+4 \\
4.68 \mathrm{E}+4 \\
7.38 \mathrm{E}+4 \\
1.35 \mathrm{E}+5 \\
2.23 \mathrm{E}+5 \\
3.23 \mathrm{E}+5 \\
5.03 \mathrm{E}+5 \\
6.77 \mathrm{E}+5 \\
1.20 \mathrm{E}+6 \\
1.97 \mathrm{E}+6\end{array}$ & $\begin{array}{l}0.2119 \\
0.2064 \\
0.2053 \\
0.2032 \\
0.2018 \\
0.2011 \\
0.2006 \\
0.2000 \\
0.1994 \\
0.1955 \\
0.1944 \\
0.1929 \\
0.1918 \\
0.1909 \\
0.1900 \\
0.1894 \\
0.1882 \\
0.1970\end{array}$ & $\begin{array}{l}0.1784 \\
0.1728 \\
0.1709 \\
0.1665 \\
0.1633 \\
0.1617 \\
0.1603 \\
0.1589 \\
0.1575 \\
0.1489 \\
0.1466 \\
0.1438 \\
0.1416 \\
0.1401 \\
0.1384 \\
0.1374 \\
0.1355 \\
0.1340 \\
0.1326\end{array}$ & $\begin{array}{l}0.1454 \\
0.1351 \\
0.1315 \\
0.1237 \\
0.1183 \\
0.1158 \\
0.1137 \\
0.1115 \\
0.1094 \\
0.0977 \\
0.0948 \\
0.0915 \\
0.0890 \\
0.0875 \\
0.0857 \\
0.0847 \\
0.0829 \\
0.0816 \\
0.0804\end{array}$ & $\begin{array}{l}0.1274 \\
0.1191 \\
0.1160 \\
0.1087 \\
0.1034 \\
0.1009 \\
0.0987 \\
0.0965 \\
0.0943 \\
0.0818 \\
0.0786 \\
0.0749 \\
0.0722 \\
0.0704 \\
0.0685 \\
0.0673 \\
0.0652 \\
0.0636 \\
0.0622\end{array}$ & $\begin{array}{l}0.1287 \\
0.1244 \\
0.1220 \\
0.1146 \\
0.1081 \\
0.1048 \\
0.1018 \\
0.0988 \\
0.0958 \\
0.0798 \\
0.0763 \\
0.0726 \\
0.0700 \\
0.0685 \\
0.0669 \\
0.0660 \\
0.0645 \\
0.0635 \\
0.0627\end{array}$ & $\begin{array}{l}0.1252 \\
0.1224 \\
0.1206 \\
0.1146 \\
0.1087 \\
0.1054 \\
0.1024 \\
0.0992 \\
0.0960 \\
0.0780 \\
0.0739 \\
0.0696 \\
0.0666 \\
0.0649 \\
0.0630 \\
0.0620 \\
0.0603 \\
0.0591 \\
0.0582\end{array}$ & $\begin{array}{l}0.1268 \\
0.1240 \\
0.1224 \\
0.1172 \\
0.1119 \\
0.1089 \\
0.1061 \\
0.1030 \\
0.0999 \\
0.0805 \\
0.0756 \\
0.0700 \\
0.0660 \\
0.0635 \\
0.0608 \\
0.0593 \\
0.0566 \\
0.0546 \\
0.0529\end{array}$ & $\begin{array}{l}0.1451 \\
0.1425 \\
0.1408 \\
0.1348 \\
0.1280 \\
0.1240 \\
0.1202 \\
0.1160 \\
0.1117 \\
0.0851 \\
0.0789 \\
0.0722 \\
0.0677 \\
0.0649 \\
0.0621 \\
0.0605 \\
0.0579 \\
0.0561 \\
0.0546\end{array}$ \\
\hline
\end{tabular}


TABLE E.6. Matric Head Data from the Grass Site (second experiment)

\begin{tabular}{lllllllllr} 
& \multicolumn{8}{c}{ Matric Head, cm, at Depth, cm } \\
\cline { 2 - 4 } & 15 & 30 & $\frac{45}{60}$ & $\frac{90}{120}$ & 150 & 180 \\
\hline $0.00 \mathrm{E}+0$ & -15 & -10 & -11 & -9 & -4 & -7 & -6 & -4 \\
$8.99 \mathrm{E}+2$ & -18 & -13 & -11 & -9 & -4 & -7 & -6 & -5 \\
$1.32 \mathrm{E}+3$ & -20 & -14 & -11 & -9 & -4 & -7 & -6 & -5 \\
$2.76 \mathrm{E}+3$ & -25 & -17 & -12 & -9 & -4 & -8 & -7 & -5 \\
$4.50 \mathrm{E}+3$ & -32 & -21 & -13 & -9 & -4 & -9 & -8 & -6 \\
$5.70 \mathrm{E}+3$ & -37 & -24 & -14 & -9 & -4 & -10 & -9 & -6 \\
$7.02 \mathrm{E}+3$ & -40 & -26 & -15 & -10 & -5 & -10 & -9 & -7 \\
$8.70 \mathrm{E}+3$ & -42 & -28 & -17 & -11 & -7 & -11 & -10 & -8 \\
$1.08 \mathrm{E}+4$ & -44 & -30 & -19 & -12 & -10 & -11 & -10 & -9 \\
$4.68 \mathrm{E}+4$ & -49 & -35 & -24 & -15 & -12 & -16 & -12 & -12 \\
$7.38 \mathrm{E}+4$ & -52 & -38 & -26 & -17 & -14 & -18 & -14 & -13 \\
$1.35 \mathrm{E}+5$ & -56 & -42 & -29 & -18 & -15 & -19 & -17 & -15 \\
$2.23 \mathrm{E}+5$ & -60 & -46 & -32 & -20 & -17 & -21 & -18 & -17 \\
$3.23 \mathrm{E}+5$ & -63 & -49 & -35 & -22 & -19 & -22 & -19 & -18 \\
$5.03 \mathrm{E}+5$ & -66 & -52 & -38 & -24 & -21 & -23 & -20 & -20 \\
$6.77 \mathrm{E}+5$ & -69 & -55 & -41 & -26 & -22 & -24 & -21 & -21 \\
$1.20 \mathrm{E}+6$ & -73 & -59 & -46 & -30 & -23 & -25 & -22 & -23 \\
$1.97 \mathrm{E}+6$ & -75 & -61 & -49 & -33 & -24 & -26 & -23 & -24 \\
$3.2 \mathrm{EE}+6$ & -78 & -64 & -50 & -34 & -24 & -28 & -25 & -27
\end{tabular}

TABLE E.7. Time-Averaged Water Content from the Grass Site (second experiment)

Water Content, $\mathrm{cm}^{3} / \mathrm{cm}^{3}$, at Depth, $\mathrm{cm}$

\begin{tabular}{|c|c|c|c|c|c|c|c|c|}
\hline Time, $s$ & 15 & 30 & 45 & 60 & 90 & 120 & 150 & 180 \\
\hline $\begin{array}{l}4.32 E+2 \\
1.12 E+3 \\
2.07 E+3 \\
3.63 E+3 \\
5.10 E+3 \\
6.39 E+3 \\
7.86 E+3 \\
9.76 E+3 \\
2.88 E+4 \\
6.03 E+4 \\
1.04 E+5 \\
1.79 E+5 \\
2.73 E+5 \\
4.13 E+5 \\
5.90 E+5 \\
9.37 E+5 \\
1.59 E+6 \\
2.61 E+6\end{array}$ & $\begin{array}{l}0.209 \\
0.206 \\
0.204 \\
0.203 \\
0.201 \\
0.201 \\
0.200 \\
0.200 \\
0.197 \\
0.195 \\
0.194 \\
0.192 \\
0.191 \\
0.190 \\
0.190 \\
0.189 \\
0.188 \\
0.187\end{array}$ & $\begin{array}{l}0.176 \\
0.172 \\
0.169 \\
0.165 \\
0.163 \\
0.161 \\
0.160 \\
0.158 \\
0.153 \\
0.148 \\
0.145 \\
0.143 \\
0.141 \\
0.139 \\
0.138 \\
0.136 \\
0.135 \\
0.133\end{array}$ & $\begin{array}{l}0.140 \\
0.133 \\
0.128 \\
0.121 \\
0.117 \\
0.115 \\
0.113 \\
0.110 \\
0.104 \\
0.096 \\
0.093 \\
0.090 \\
0.088 \\
0.087 \\
0.085 \\
0.084 \\
0.082 \\
0.081\end{array}$ & $\begin{array}{l}0.123 \\
0.118 \\
0.112 \\
0.106 \\
0.102 \\
0.100 \\
0.098 \\
0.095 \\
0.088 \\
0.080 \\
0.077 \\
0.074 \\
0.071 \\
0.069 \\
0.068 \\
0.066 \\
0.064 \\
0.063\end{array}$ & $\begin{array}{l}0.127 \\
0.123 \\
0.118 \\
0.111 \\
0.106 \\
0.103 \\
0.100 \\
0.097 \\
0.088 \\
0.078 \\
0.074 \\
0.071 \\
0.069 \\
0.068 \\
0.066 \\
0.065 \\
0.064 \\
0.063\end{array}$ & $\begin{array}{l}0.124 \\
0.121 \\
0.118 \\
0.112 \\
0.107 \\
0.104 \\
0.101 \\
0.098 \\
0.087 \\
0.076 \\
0.072 \\
0.068 \\
0.066 \\
0.064 \\
0.063 \\
0.061 \\
0.060 \\
0.059\end{array}$ & $\begin{array}{l}0.125 \\
0.123 \\
0.120 \\
0.115 \\
0.110 \\
0.107 \\
0.105 \\
0.101 \\
0.090 \\
0.078 \\
0.073 \\
0.068 \\
0.065 \\
0.062 \\
0.060 \\
0.058 \\
0.056 \\
0.054\end{array}$ & $\begin{array}{l}0.144 \\
0.142 \\
0.138 \\
0.131 \\
0.126 \\
0.122 \\
0.118 \\
0.114 \\
0.098 \\
0.082 \\
0.076 \\
0.070 \\
0.066 \\
0.064 \\
0.061 \\
0.059 \\
0.057 \\
0.055\end{array}$ \\
\hline
\end{tabular}


TABLE E.8. Hydraulic Conductivity Data from the Grass Site (second experiment)

Hydraulic Conductivity, $\mathrm{cm} / \mathrm{s}$, at Depth, $\mathrm{cm}$

\begin{tabular}{|c|c|c|c|c|c|c|c|}
\hline$n e, s$ & 30 & 45 & 60 & 90 & 120 & 150 & 180 \\
\hline $\begin{array}{l}32 \mathrm{E}+2 \\
12 \mathrm{E}+3 \\
07 \mathrm{E}+3 \\
63 \mathrm{E}+3 \\
10 \mathrm{E}+3 \\
39 \mathrm{E}+3 \\
86 \mathrm{E}+3 \\
76 \mathrm{E}+3 \\
88 \mathrm{E}+4 \\
03 \mathrm{E}+4 \\
04 \mathrm{E}+5 \\
79 \mathrm{E}+5 \\
73 \mathrm{E}+5 \\
13 \mathrm{E}+5 \\
90 \mathrm{E}+5 \\
37 \mathrm{E}+5\end{array}$ & $\begin{array}{l}2.26 \mathrm{E}-4 \\
1.26 \mathrm{E}-4 \\
8.83 \mathrm{E}-5 \\
6.81 \mathrm{E}-5 \\
7.70 \mathrm{E}-5 \\
8.28 \mathrm{E}-5 \\
8.55 \mathrm{E}-5 \\
6.86 \mathrm{E}-5 \\
2.54 \mathrm{E}-5 \\
1.04 \mathrm{E}-5 \\
7.71 \mathrm{E}-6 \\
5.59 \mathrm{E}-6 \\
4.76 \mathrm{E}-6 \\
2.75 \mathrm{E}-6 \\
1.81 \mathrm{E}-6 \\
9.53 \mathrm{E}-7 \\
3.72 \mathrm{E}-7 \\
2.60 \mathrm{E}-7\end{array}$ & $\begin{array}{l}3.46 \mathrm{E}-4 \\
2.23 \mathrm{E}-4 \\
1.53 \mathrm{E}-4 \\
1.03 \mathrm{E}-4 \\
8.86 \mathrm{E}-5 \\
7.56 \mathrm{E}-5 \\
6.73 \mathrm{E}-5 \\
5.74 \mathrm{E}-5 \\
2.31 \mathrm{E}-5 \\
9.47 \mathrm{E}-6 \\
6.60 \mathrm{E}-6 \\
5.19 \mathrm{E}-6\end{array}$ & $\begin{array}{l}5.59 \mathrm{E}-4 \\
3.65 \mathrm{E}-4 \\
2.38 \mathrm{E}-4 \\
1.41 \mathrm{E}-4 \\
1.01 \mathrm{E}-4 \\
7.86 \mathrm{E}-5 \\
6.41 \mathrm{E}-5 \\
4.98 \mathrm{E}-5 \\
1.76 \mathrm{E}-5 \\
6.40 \mathrm{E}-6 \\
3.53 \mathrm{E}-6 \\
1.93 \mathrm{E}-6 \\
1.21 \mathrm{E}-6 \\
7.62 \mathrm{E}-7 \\
5.03 \mathrm{E}-7 \\
3.55 \mathrm{E}-7 \\
2.11 \mathrm{E}-7 \\
1.31 \mathrm{E}-7\end{array}$ & $\begin{array}{l}7.06 \mathrm{E}-4 \\
5.20 \mathrm{E}-4 \\
3.61 \mathrm{E}-4 \\
2.18 \mathrm{E}-4 \\
1.51 \mathrm{E}-4 \\
1.20 \mathrm{E}-4 \\
9.62 \mathrm{E}-5 \\
7.71 \mathrm{E}-5 \\
2.54 \mathrm{E}-5 \\
8.28 \mathrm{E}-6 \\
4.26 \mathrm{E}-6 \\
2.17 \mathrm{E}-6 \\
1.28 \mathrm{E}-6 \\
7.80 \mathrm{E}-7 \\
4.95 \mathrm{E}-7 \\
3.11 \mathrm{E}-7 \\
1.65 \mathrm{E}-7 \\
9.27 \mathrm{E}-8\end{array}$ & $\begin{array}{l}7.75 \mathrm{E}-4 \\
6.31 \mathrm{E}-4 \\
4.73 \mathrm{E}-4 \\
3.05 \mathrm{E}-4 \\
2.18 \mathrm{E}-4 \\
1.76 \mathrm{E}-4 \\
1.43 \mathrm{E}-4 \\
1.18 \mathrm{E}-4 \\
3.95 \mathrm{E}-5 \\
1.26 \mathrm{E}-5 \\
6.20 \mathrm{E}-6 \\
3.08 \mathrm{E}-6 \\
1.76 \mathrm{E}-6 \\
1.07 \mathrm{E}-6 \\
6.57 \mathrm{E}-7 \\
3.92 \mathrm{E}-7 \\
1.94 \mathrm{E}-7 \\
1.03 \mathrm{E}-7\end{array}$ & $\begin{array}{l}9.34 \mathrm{E}-4 \\
7.99 \mathrm{E}-4 \\
6.36 \mathrm{E}-4 \\
4.41 \mathrm{E}-4 \\
3.33 \mathrm{E}-4 \\
2.71 \mathrm{E}-4 \\
2.18 \mathrm{E}-4 \\
1.73 \mathrm{E}-4 \\
5.80 \mathrm{E}-5 \\
1.91 \mathrm{E}-5 \\
9.45 \mathrm{E}-6 \\
4.65 \mathrm{E}-6 \\
2.58 \mathrm{E}-6 \\
1.54 \mathrm{E}-6 \\
9.07 \mathrm{E}-7 \\
5.35 \mathrm{E}-7 \\
2.62 \mathrm{E}-7 \\
1.37 \mathrm{E}-7\end{array}$ & $\begin{array}{l}1.04 \mathrm{E}-3 \\
9.20 \mathrm{E}-4 \\
7.65 \mathrm{E}-4 \\
5.60 \mathrm{E}-4 \\
4.37 \mathrm{E}-4 \\
3.6 \mathrm{E}-4 \\
2.92 \mathrm{E}-4 \\
2.30 \mathrm{E}-4 \\
7.55 \mathrm{E}-5 \\
2.42 \mathrm{E}-5 \\
1.24 \mathrm{E}-5 \\
6.08 \mathrm{E}-6 \\
3.32 \mathrm{E}-6 \\
1.94 \mathrm{E}-6 \\
1.13 \mathrm{E}-6 \\
6.55 \mathrm{E}-7 \\
3.16 \mathrm{E}-7 \\
1.63 \mathrm{E}-7\end{array}$ \\
\hline
\end{tabular}

IABLE E.9. Water Content Data from the McGee Ranch (second experiment)

\begin{tabular}{|c|c|c|c|c|c|}
\hline Time, $s$ & 15 & 30 & 45 & $\frac{61}{60}$ & 90 \\
\hline $\begin{array}{l}0.00 \mathrm{E}+0 \\
4.50 \mathrm{E}+3 \\
5.28 \mathrm{E}+3 \\
5.82 \mathrm{E}+3 \\
7.62 \mathrm{E}+3 \\
8.40 \mathrm{E}+3 \\
9.42 \mathrm{E}+3 \\
1.05 \mathrm{E}+4 \\
1.23 \mathrm{E}+4 \\
1.45 \mathrm{E}+4 \\
1.65 \mathrm{E}+4 \\
1.83 \mathrm{E}+4 \\
2.00 \mathrm{E}+4 \\
7.71 \mathrm{E}+4 \\
9.75 \mathrm{E}+4 \\
1.76 \mathrm{E}+5 \\
3.56 \mathrm{E}+5 \\
5.31 \mathrm{E}+5 \\
1.05 \mathrm{E}+6 \\
1.81 \mathrm{E}+6 \\
2.76 \mathrm{E}+6\end{array}$ & $\begin{array}{l}0.3813 \\
0.3700 \\
0.3677 \\
0.3660 \\
0.3604 \\
0.3580 \\
0.3550 \\
0.3518 \\
0.3467 \\
0.3409 \\
0.3357 \\
0.3314 \\
0.3276 \\
0.2613 \\
0.2502 \\
0.2248 \\
0.1995 \\
0.1876 \\
0.1706 \\
0.1595 \\
0.1524\end{array}$ & $\begin{array}{l}0.4073 \\
0.3981 \\
0.3960 \\
0.3945 \\
0.3894 \\
0.3871 \\
0.3842 \\
0.3811 \\
0.3760 \\
0.3701 \\
0.3647 \\
0.3601 \\
0.3561 \\
0.2795 \\
0.2662 \\
0.2361 \\
0.2067 \\
0.1931 \\
0.1742 \\
0.1623 \\
0.1548\end{array}$ & $\begin{array}{l}0.4089 \\
0.4005 \\
0.3988 \\
0.3977 \\
0.3941 \\
0.3925 \\
0.3905 \\
0.3884 \\
0.3849 \\
0.3810 \\
0.3775 \\
0.3745 \\
0.3718 \\
0.3163 \\
0.3051 \\
0.2769 \\
0.2446 \\
0.2276 \\
0.2009 \\
0.1816 \\
0.1680\end{array}$ & $\begin{array}{l}0.4103 \\
0.4042 \\
0.4030 \\
0.4022 \\
0.3994 \\
0.3982 \\
0.3967 \\
0.3950 \\
0.3923 \\
0.3892 \\
0.3863 \\
0.3838 \\
0.3818 \\
0.3309 \\
0.3198 \\
0.2913 \\
0.2578 \\
0.2400 \\
0.2117 \\
0.1912 \\
0.1768\end{array}$ & $\begin{array}{l}0.4044 \\
0.4037 \\
0.4035 \\
0.4034 \\
0.4029 \\
0.4026 \\
0.4023 \\
0.4020 \\
0.4013 \\
0.4005 \\
0.3997 \\
0.3990 \\
0.3983 \\
0.3677 \\
0.3567 \\
0.3206 \\
0.2691 \\
0.2408 \\
0.1993 \\
0.1730 \\
0.1566\end{array}$ \\
\hline
\end{tabular}


TABLE E.10. Matric Head Data from the McGee Ranch (second experiment)

Time, $s$

$0.00 E+0$

$4.50 \mathrm{E}+3$

$5.28 \mathrm{E}+3$

$5.82 \mathrm{E}+3$

$7.62 \mathrm{E}+3$

$8.40 \mathrm{E}+3$

$9.42 \mathrm{E}+3$

$1.05 \mathrm{E}+4$

$1.23 \mathrm{E}+4$

$1.45 \mathrm{E}+4$

$1.65 \mathrm{E}+4$

$1.83 E+4$

2.00E+4

$7.71 \mathrm{E}+4$

$9.75 \mathrm{E}+4$

$1.76 \mathrm{E}+4$

$3.56 \mathrm{E}+5$

$5.31 \mathrm{E}+5$

$1.05 \mathrm{E}+6$

$1.81 \mathrm{E}+6$

$2.76 \mathrm{E}+6$
Matric Head, $\mathrm{cm}$, at Depth, $\mathrm{cm}$

\begin{tabular}{lllll}
\hline 15 & 30 & 45 & 60 & $\frac{90}{10}$ \\
\cline { 2 - 5 }-34 & -35 & -24 & -17 & -10 \\
-59 & -56 & -50 & -41 & -19 \\
-63 & -60 & -54 & -45 & -24 \\
-66 & -63 & -58 & -48 & -27 \\
-76 & -71 & -68 & -58 & -38 \\
-81 & -75 & -73 & -62 & -43 \\
-85 & -79 & -77 & -66 & -48 \\
-88 & -83 & -80 & -69 & -53 \\
-93 & -90 & -85 & -74 & -61 \\
-101 & -96 & -91 & -80 & -66 \\
-107 & -101 & -97 & -85 & -71 \\
-109 & -103 & -100 & -87 & -74 \\
-110 & -106 & -103 & -90 & -77 \\
-151 & -148 & -147 & -133 & -115 \\
-160 & -156 & -155 & -141 & -123 \\
-186 & -180 & -180 & -166 & -147 \\
-226 & -212 & -214 & -200 & -183 \\
-250 & -235 & -234 & -220 & -204 \\
-292 & -278 & -276 & -262 & -247 \\
-326 & -312 & -310 & -298 & -288 \\
-358 & -344 & -346 & -338 & -327
\end{tabular}


TABLE E.11. Time-Averaged Water Content Data from the McGee Ranch (second experiment)

\begin{tabular}{|c|c|c|c|c|c|}
\hline \multirow[b]{2}{*}{ Time, $s$} & \multicolumn{5}{|c|}{ Water Content, $\mathrm{cm}^{3} / \mathrm{cm}^{3}$, at Depth, $\mathrm{cm}$} \\
\hline & 15 & 30 & 45 & 60 & 90 \\
\hline $\begin{array}{l}2.25 \mathrm{E}+3 \\
4.92 \mathrm{E}+3 \\
5.53 \mathrm{E}+3 \\
6.74 \mathrm{E}+3 \\
8.04 \mathrm{E}+3 \\
8.90 \mathrm{E}+3 \\
9.94 \mathrm{E}+3 \\
1.14 \mathrm{E}+4 \\
1.34 \mathrm{E}+4 \\
1.55 \mathrm{E}+4 \\
1.74 \mathrm{E}+4 \\
1.91 \mathrm{E}+4 \\
4.86 \mathrm{E}+4 \\
8.73 \mathrm{E}+4 \\
1.37 \mathrm{E}+5 \\
2.66 \mathrm{E}+5 \\
4.43 \mathrm{E}+5 \\
7.90 \mathrm{E}+5 \\
1.43 \mathrm{E}+5 \\
2.29 \mathrm{E}+5\end{array}$ & $\begin{array}{l}0.376 \\
0.369 \\
0.367 \\
0.363 \\
0.359 \\
0.356 \\
0.353 \\
0.349 \\
0.344 \\
0.338 \\
0.334 \\
0.330 \\
0.294 \\
0.256 \\
0.237 \\
0.212 \\
0.194 \\
0.179 \\
0.165 \\
0.156\end{array}$ & $\begin{array}{l}0.403 \\
0.397 \\
0.395 \\
0.392 \\
0.388 \\
0.386 \\
0.383 \\
0.379 \\
0.373 \\
0.367 \\
0.362 \\
0.358 \\
0.318 \\
0.273 \\
0.251 \\
0.221 \\
0.200 \\
0.184 \\
0.168 \\
0.159\end{array}$ & $\begin{array}{l}0.405 \\
0.400 \\
0.398 \\
0.396 \\
0.393 \\
0.392 \\
0.389 \\
0.387 \\
0.383 \\
0.379 \\
0.376 \\
0.373 \\
0.344 \\
0.311 \\
0.291 \\
0.261 \\
0.236 \\
0.214 \\
0.191 \\
0.175\end{array}$ & $\begin{array}{l}0.407 \\
0.404 \\
0.403 \\
0.401 \\
0.399 \\
0.397 \\
0.396 \\
0.394 \\
0.391 \\
0.388 \\
0.385 \\
0.383 \\
0.356 \\
0.325 \\
0.306 \\
0.275 \\
0.249 \\
0.226 \\
0.201 \\
0.184\end{array}$ & $\begin{array}{l}0.404 \\
0.404 \\
0.403 \\
0.403 \\
0.403 \\
0.402 \\
0.402 \\
0.402 \\
0.401 \\
0.400 \\
0.399 \\
0.399 \\
0.383 \\
0.362 \\
0.339 \\
0.295 \\
0.255 \\
0.220 \\
0.186 \\
0.165\end{array}$ \\
\hline
\end{tabular}


IABLE E.12. Hydraulic Conductivity Data from the McGee Ranch (second experiment)

\begin{tabular}{|c|c|c|c|c|c|}
\hline \multirow[b]{2}{*}{ Time, $s$} & \multicolumn{5}{|c|}{ Hydraulic Conductivity, $\mathrm{cm} / \mathrm{s}$, at Depth, $\mathrm{cm}$} \\
\hline & 15 & 30 & 45 & 60 & 90 \\
\hline $\begin{array}{l}2.25 \mathrm{E}+3 \\
4.92 \mathrm{E}+3 \\
5.53 \mathrm{E}+3 \\
6.74 \mathrm{E}+3 \\
8.04 \mathrm{E}+3 \\
8.90 \mathrm{E}+3 \\
9.94 \mathrm{E}+3 \\
1.14 \mathrm{E}+4 \\
1.34 \mathrm{E}+4 \\
1.55 \mathrm{E}+4 \\
1.74 \mathrm{E}+4 \\
1.91 \mathrm{E}+4 \\
4.86 \mathrm{E}+4 \\
8.73 \mathrm{E}+4 \\
1.37 \mathrm{E}+5 \\
2.66 \mathrm{E}+5 \\
4.43 \mathrm{E}+5 \\
7.90 \mathrm{E}+5 \\
1.43 \mathrm{E}+6 \\
2.29 \mathrm{E}+6\end{array}$ & $\begin{array}{l}4.03 \mathrm{E}-5 \\
5.55 \mathrm{E}-5 \\
5.86 \mathrm{E}-5 \\
6.37 \mathrm{E}-5 \\
7.31 \mathrm{E}-5 \\
7.36 \mathrm{E}-5 \\
7.02 \mathrm{E}-5 \\
5.78 \mathrm{E}-5 \\
5.49 \mathrm{E}-5 \\
6.04 \mathrm{E}-5 \\
5.98 \mathrm{E}-5 \\
5.10 \mathrm{E}-5 \\
2.27 \mathrm{E}-5 \\
1.06 \mathrm{E}-5 \\
7.32 \mathrm{E}-6 \\
6.31 \mathrm{E}-6 \\
3.07 \mathrm{E}-5 \\
1.47 \mathrm{E}-5 \\
3.27 \mathrm{E}-6 \\
1.68 \mathrm{E}-6\end{array}$ & $\begin{array}{l}1.05 \mathrm{E}-4 \\
1.24 \mathrm{E}-4 \\
1.27 \mathrm{E}-4 \\
1.25 \mathrm{E}-4 \\
1.25 \mathrm{E}-4 \\
1.19 \mathrm{E}-4 \\
1.20 \mathrm{E}-4 \\
1.16 \mathrm{E}-4 \\
1.16 \mathrm{E}-4 \\
1.16 \mathrm{E}-4 \\
1.07 \mathrm{E}-4 \\
9.40 \mathrm{E}-5 \\
4.43 \mathrm{E}-5 \\
2.02 \mathrm{E}-5 \\
1.25 \mathrm{E}-5 \\
6.26 \mathrm{E}-6 \\
3.97 \mathrm{E}-6 \\
2.16 \mathrm{E}-6 \\
9.52 \mathrm{E}-7 \\
4.26 \mathrm{E}-7\end{array}$ & $\begin{array}{l}2.25 \mathrm{E}-4 \\
2.47 \mathrm{E}-4 \\
2.54 \mathrm{E}-4 \\
2.39 \mathrm{E}-4 \\
2.28 \mathrm{E}-4 \\
2.18 \mathrm{E}-4 \\
2.26 \mathrm{E}-4 \\
2.41 \mathrm{E}-4 \\
2.46 \mathrm{E}-4 \\
2.36 \mathrm{E}-4 \\
2.24 \mathrm{E}-4 \\
2.12 \mathrm{E}-4 \\
1.11 \mathrm{E}-4 \\
5.23 \mathrm{E}-5 \\
3.06 \mathrm{E}-5 \\
1.23 \mathrm{E}-5 \\
6.24 \mathrm{E}-6 \\
3.45 \mathrm{E}-6 \\
1.50 \mathrm{E}-6 \\
5.91 \mathrm{E}-7\end{array}$ & $\begin{array}{l}4.51 \mathrm{E}-4 \\
4.70 \mathrm{E}-4 \\
4.75 \mathrm{E}-4 \\
4.79 \mathrm{E}-4 \\
4.69 \mathrm{E}-4 \\
4.34 \mathrm{E}-4 \\
3.99 \mathrm{E}-4 \\
3.37 \mathrm{E}-4 \\
3.06 \mathrm{E}-4 \\
3.08 \mathrm{E}-4 \\
3.02 \mathrm{E}-4 \\
2.84 \mathrm{E}-4 \\
1.90 \mathrm{E}-4 \\
1.19 \mathrm{E}-4 \\
7.65 \mathrm{E}-5 \\
3.35 \mathrm{E}-5 \\
1.53 \mathrm{E}-5 \\
7.15 \mathrm{E}-6 \\
2.64 \mathrm{E}-6 \\
1.13 \mathrm{E}-6\end{array}$ & $\begin{array}{l}8.07 \mathrm{E}-4 \\
6.30 \mathrm{E}-4 \\
5.92 \mathrm{E}-4 \\
5.75 \mathrm{E}-4 \\
5.29 \mathrm{E}-4 \\
4.59 \mathrm{E}-4 \\
4.12 \mathrm{E}-4 \\
3.38 \mathrm{E}-4 \\
3.02 \mathrm{E}-4 \\
3.01 \mathrm{E}-4 \\
2.81 \mathrm{E}-4 \\
2.54 \mathrm{E}-4 \\
1.84 \mathrm{E}-4 \\
1.26 \mathrm{E}-4 \\
8.78 \mathrm{E}-5 \\
4.19 \mathrm{E}-5 \\
1.97 \mathrm{E}-5 \\
9.27 \mathrm{E}-6 \\
3.53 \mathrm{E}-6 \\
1.70 \mathrm{E}-6\end{array}$ \\
\hline
\end{tabular}




\section{DISTRIBUTION}

No. of

Copies

OFFSITE

10 DOE Office of Scientific and Technical Information

W. Brewer

Office of High-Level Nuclear Waste Management

Washington State Department of Ecology

Mai1 Stop PV-11

Olympia, WA 98504

G. S. Campbel1

Agronomy Department

Washington State University

Pullman, WA 99164

A. T. Clark

Division of Fuel Material Safety

Nuclear Regulatory Commission

Washington, DC 20555

D. Hillel

Department of Plant and Soil Science

12A Stockbridge Hall

University of Massachusetts

Amherst, MA 01003

T. J. Nicholson

U.S. Nuclear Regulatory Commission

Div. of Engineering Safety

MS NL-005

Washington, DC 20555

E. O'Donnel1

Earth Sciences Branch

Division of Health, Siting and Waste Management Research

U.S. Nuclear Regulatory

Commission

Washington, DC 20555
No. of

Copies

J. Rense1

High-Level Waste Management

Washington State Department

of Ecology

Mail Stop PV-11

01ympia, WA 98504

D. Stephens

Dept. of Geosciences

New Mexico Institute of Mining and Technology

Socorro, NM 87801

S. Tyler

Desert Research Institute

P.0. Box 60220

Reno, NV 89506

E. P. Weeks

U.S. Geological Survey

Federal Center, Mail Stop 413

Denver, CO 80225

P. J. Wierenga

Dept. of Soil Science

New Mexico State University

Las Cruces, NM 88004

I. J. Winograd

U.S. Geological Survey

National Center, Mail Stop 432

Reston, VA 22092

\section{ONSITE}

12 DOE Richland Operations office

E. A. Bracken

G. J. Bracken

J. J. Broderick

C. E. Collantes

C. R. Delannoy

R. E. Gerton 
No. of

Copies

ONSITE
J. R. Hunter
0 . L. 01son
J. M. Peterson
G. W. Rosenwald
M. W. Shupe
J. J. Sutey

29 Westinghouse Hanford Company

M. R. Adams

T. B. Bergman

L. C. Brown

J. W. Cammann

R. A. Carlson

H. F. Daugherty

J. D. Davis

C. DeFigh-Price

K. A. Gasper

C. J. Geier

W. F. Heine

J. M. Henderson

M. T. Jansky

V. G. Johnson

K. N. Jordan

D. S. Landeen

R. E. Lerch

H. E. McGuire

K. W. Owens

K. L. Petersen

S. J. Phillips

J. F. Relyea

R. C. Routson

W. W. Schulz

S. A. Weigman

N. R. Wing

D. D. Wodrich

R. D. Wojtasek

D. E. Wood

Pacific Northwest Laboratory

L. L. Cadwe 17

M. D. Campbe 11

J. W. Cary

J. L. Downs (5)
No. of

Copies

J. W. Falco

M. J. Fayer

M. G. Foley

H. D. Freeman

G. W. Gee (15)

M. J. Graham

J. M. Hales

K. R. Hanson

$P$. C. Hays

P. R. Heller

T. L. Jones

C. T. Kincaid

R. R. Kirkham

G. V. Last

M. W. Ligotke

S. 0. Link

J. F. McBride

J. L. McElroy

D. H. Mitchel1

E. M. Murphy

R. W. Nelson

W. H. Rickard

M. L. Rockhold (5)

L. E. Rogers

C. S. Simmons

R. L. Skaggs

J. A. Stott Temyre

G. P. Streile

R. L. Treat

W. H. Walters

W. J. Waugh

R. E. Wildung

Publishing Coordination

Technical Report Files 